\title{
Enantio- and Diastereoselective Synthesis of Functionalized Carbocycles by Cu-Catalyzed Borylative Cyclization of Alkynes with Ketones
}

\author{
Joseph M. Zanghi, Shuang Liu, Simon J. Meek* \\ Department of Chemistry, The University of North Carolina at Chapel Hill, Chapel Hill, North Carolina
} 27599-3290.

\section{SUPPORTING INFORMATION}

Table of Contents

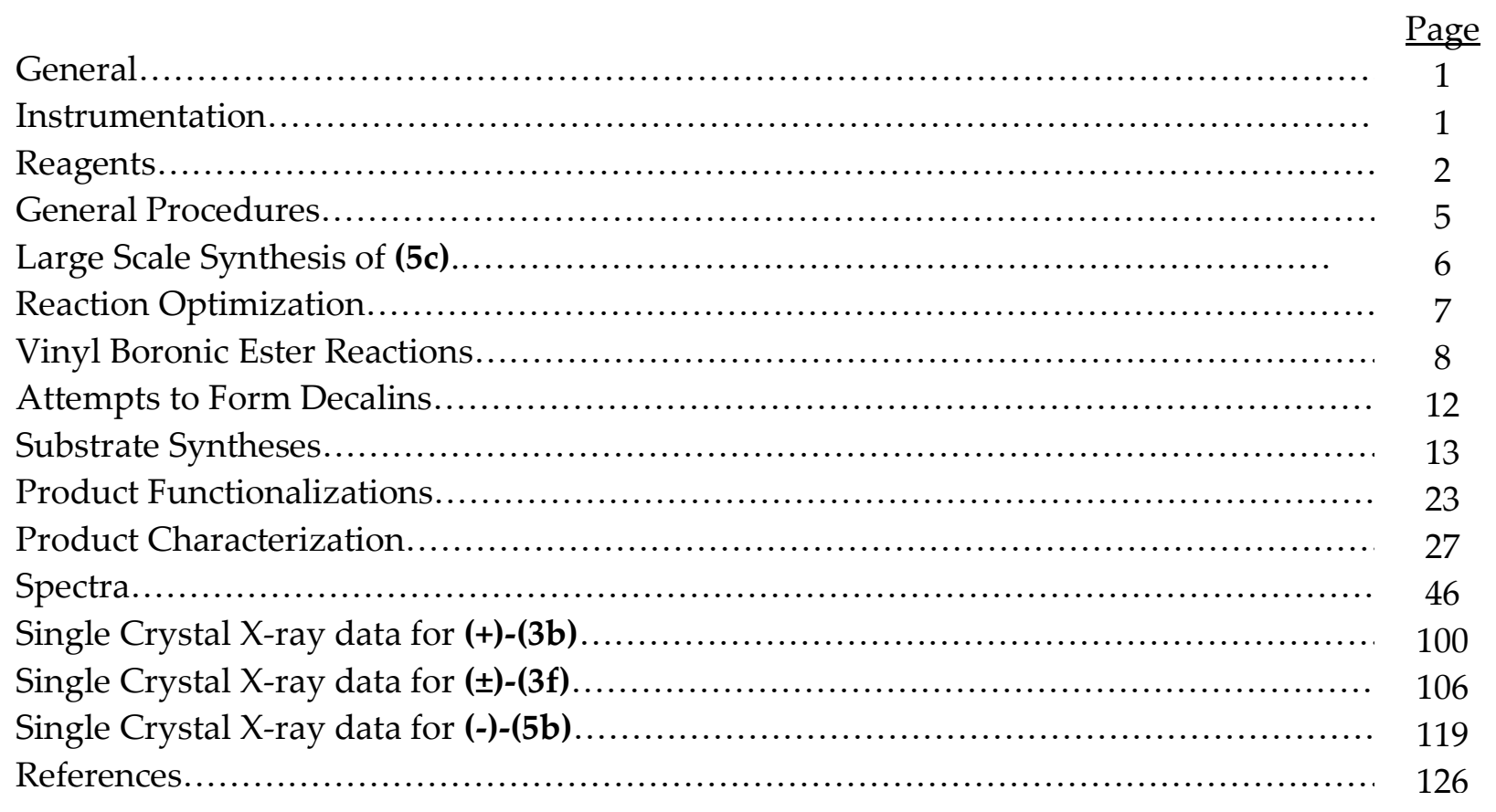

- General: All reactions were carried out in oven-dried $\left(150{ }^{\circ} \mathrm{C}\right)$ or flame-dried glassware under an inert atmosphere of dried $\mathrm{N}_{2}$ unless otherwise noted. Analytical thin-layer chromatography was performed on glass plates coated with $0.25 \mathrm{~mm}$ of $60 \AA$ mesh silica gel. Plates were visualized by exposure to UV light $(254 \mathrm{~nm})$ and/or immersion into $\mathrm{KMnO}_{4}$ or Seebach Stain followed by heating. Column chromatography was performed using silica gel P60 (mesh 230-400) supplied by Silicycle, and refers to flash chromatography unless stated otherwise. Tetrahydrofuran, dichloromethane, toluene, diethyl ether, toluene, benzene, and $n$ hexane (OmniSolv) were sparged with argon and then purified under a positive pressure of argon through a SG Water, USA Solvent Purification System, through two columns of neutral alumina. The ambient temperature in the laboratory was approximately $22{ }^{\circ} \mathrm{C}$. 
- Instrumentation: All ${ }^{1} \mathrm{H}$ NMR spectra were recorded on Bruker Spectrometers (AVANCE600, AVANCE-500 and AVANCE-400). Chemical shifts are reported in ppm from tetramethylsilane and referenced to the residual protio solvent peak ( $\mathrm{CDCl}_{3}: \delta$ 7.26, DMSO-d6: $\delta$ 2.50, $\mathrm{CD}_{3} \mathrm{OD}: \delta$ 3.31). Data are reported as follows: chemical shift, multiplicity ( $\mathrm{s}=$ singlet, $\mathrm{d}=$ doublet, $\mathrm{t}=$ triplet, $\mathrm{qu}=$ quartet, quint $=$ quintet, $\mathrm{br}=$ broad, $\mathrm{m}=$ multiplet, app = apparent), integration, and coupling constants are given in Hz. ${ }^{13} \mathrm{C}$ NMR spectra were recorded on Bruker Spectrometers (AVANCE II-850, AVANCE-600, and AVANCE-500) with carbon and proton decoupling. Chemical shifts are reported in ppm from tetramethylsilane and referenced to the residual protio solvent peak (CDCl 1 : $\delta 77.16$, DMSO-d6: $\left.\delta 39.52, \mathrm{CD}_{3} \mathrm{OD}: \delta 49.00\right)$. All IR spectra were recorded on a Jasco 260 Plus Fourier transform infrared spectrometer. Optical rotations were determined using a Jasco P1010 polarimeter and concentrations are reported in g/100 mL. Enantiomeric ratios were determined on an Agilent Technologies 1220 Infinity LC using the following columns: Diacel CHIRALPAK IA (4.6 mm x $250 \mathrm{~mm} \times 5 \mu \mathrm{m}$ ) and Diacel CHIRALPAK IC (4.6 mm x $250 \mathrm{~mm} \times 5 \mu \mathrm{m})$. Alternatively, enantiomeric ratios were determined on a Waters Acquity UPC2 supercritical fluid chromatography system (SFC) using the following columns: Phenomenex Lux Amylose-1 AD (4.6 mm x $150 \mathrm{~mm}$ x 5 $\mu \mathrm{m}$ ) and Phenomenex Lux Cellulose-1 OD (4.6 mm x $150 \mathrm{~mm} \times 5 \mu \mathrm{m})$. All HPLC samples were separated at $22^{\circ} \mathrm{C}$, and all SFC samples were separated at $30^{\circ} \mathrm{C}$. Racemic products were obtained by pre-mixing $(R)$ and (S)-furyl-OMebiphep for catalytic reactions forming [6,5]-bicycles and cyclopentanes; for [5,5]-bicycles, (rac)BINAP was used. High resolution mass spectrometry samples were analyzed with a ThermoScientific Q Exactive HF-X mass spectrometer. Samples were introduced via an atmospheric pressure chemical ionization (APCI) source at a flow rate of $20 \mu \mathrm{L} / \mathrm{min}$ (samples in $100 \% \mathrm{MeOH}$ ). Xcalibur (ThermoFisher, Breman, Germany) was used to analyze the data. Absolute stereochemistry was assigned by single crystal X-ray crystallography of (+)-(3b) via anomalous scattering. Both $\mathrm{X}$-ray samples were acquired using $\mathrm{Cu} \mathrm{K} \alpha(\lambda=1.54178 \AA)$ radiation.

\section{- Reagents:}

All diketones were azeotropically dried three times with benzene and stored in a $\mathrm{N}_{2}$-filled glovebox. All chiral phosphine ligands used were purchased from Strem Chemicals Inc. and used as received.

Acetone was purchased from purchased from VWR and used without further purification. Unless stated otherwise, syntheses using acetone were conducted with 'bench' acetone (ACS).

Allyl bromide was purchased from Sigma-Aldrich and used without further purification.

Bis(pinacolato)diboron $\left(\mathbf{B}_{2}(\text { pin })_{2}\right)$ was donated by AllyChem, recrystallized from boiling hexanes, azeotropically dried three times with benzene, and stored in a $\mathrm{N}_{2}$-filled glovebox.

4-bromo-but-1-yne was purchased from Alfa Aesar and used without further purification. 
Calcium hydride was purchased from Acros Organics and used without further purification. Chloroform- $d$ was purchased from Cambridge Isotope Laboratories and used without further purification.

Cinnamyl bromide (predominately trans) was purchased from Alfa Aesar and used without further purification.

Copper (I) chloride was purchased from Strem and stored in a $\mathrm{N}_{2}$-filled glovebox. 1,3-cyclohexanedione was purchased from Alfa Aesar and used without further purification. 1,3-cyclopentanedione was purchased from Alfa Aesar and used without further purification. 3,3-dimethallylbromide was purchased from Sigma-Aldrich and used without further purification.

1,3-dimethoxybenzene was purchased from Sigma-Aldrich and used without further purification.

5,5-dimethyl-1,3-cyclohexanedione was purchased from Alfa Aesar and used without further purification.

Dimethylsulfoxide- $d_{6}$ was purchased from Cambridge Isotope Laboratories and used without further purification.

1,3-Dimethyl-3,4,5,6-tetrahydro-2(1H)-pyrimidinone (DMPU) was purchased from TCI America and used without further purification.

1,4-dioxane was purchased from Alfa Aesar, pre-dried over $\mathrm{CaCl}_{2}$, filtered, distilled from $\mathrm{Na}^{0} /$ benzophenone, and stored in a $\mathrm{N}_{2}$-filled glovebox.

Grubb's $1^{\text {st }}$ Generation catalyst was purchased from Sigma-Aldrich and used without further purification.

Hexamethyldisiloxane was purchased from Alfa Aesar and stored over $4 \AA$ molecular sieves. Hydrogen peroxide was purchased from Fisher Scientific as a 30\% solution in water and stored at $-20^{\circ} \mathrm{C}$.

Iodobenzene was purchased from Alfa Aesar and used without further purification.

Martin Sulfurane (Bis[ $\alpha, \alpha$-bis(trifluoromethyl)benzenemethanolato]diphenylsulfur), was purchased from TCI America, stored in a glovebox, and used without further purification.

Methanol was purchased from VWR Life Science, dried over $\mathrm{Mg} / \mathrm{I}_{2}$, distilled, and stored over 3 Å molecular sieves under $\mathrm{N}_{2}$.

Methanol- $d 4$ was purchased from Cambridge Isotopes and used without further purification.

2-methyl-1,3-cyclohexanedione was purchased from Alfa Aesar and used without further purification.

2-methyl-1,3-cyclopentanedione was purchased from Alfa Aesar and used without further purification.

Methyl iodide was purchased from Alfa Aesar and used without further purification.

3-methyl-2,4-pentanedione was purchased from Alfa Aesar and used without further purification. 
n-Butyllithium was purchased from Strem and used without further purification.

2,4-pentanedione was purchased from Alfa Aesar and used without further purification.

Palladium (II) acetate (Pd(OAc) $)_{2}$ ) was purchased from Strem and stored in a $\mathrm{N}_{2}$-filled glovebox. Paraformaldehyde was purchased from Sigma-Aldrich and used without further purification.

Potassium carbonate was purchased from VWR Life Science and used without addition purification.

Potassium hydroxide was purchased from Fisher Scientific and used without further purification.

Potassium tert-butoxide was purchased from Strem and stored in a $\mathrm{N}_{2}$-filled glovebox.

Propargyl bromide (80 wt.\% in toluene) was purchased from Sigma-Aldrich and used without further purification.

Propionaldehyde was purchased from Sigma-Aldrich and used without further purification.

RuPhos (2-Dicyclohexylphosphino-2',6'-diisopropoxybiphenyl) was purchased from SigmaAldrich and stored in a $\mathrm{N}_{2}$-filled glovebox.

Sodium was purchased as cubes from Sigma-Aldrich and used without further purification.

Sodium hydride $(60 \%$ dispersion in mineral oil) was purchased from Sigma-Aldrich and used without further purification.

tert-Butyl alcohol was purchased from Alfa Aesar, dried over $\mathrm{MgSO}_{4}$, filtered, dried overnight over $\mathrm{CaH}_{2}$ at $30^{\circ} \mathrm{C}$, distilled, and stored over $4 \AA$ molecular sieves under $\mathrm{N}_{2}$.

tert-Butyllithium was purchased from Sigma-Aldrich (1.7 $\mathrm{M}$ in pentane). Prior to use, titration with 2-propanol using 1,10-phenanthroline (in $\mathrm{Et}_{2} \mathrm{O}$ at $0{ }^{\circ} \mathrm{C}$ ) determined the concentration was $1.37 \mathrm{M}$.

Triphenylphosphine was purchased from Sigma-Aldrich, recrystallized from boiling hexanes, azeotropically dried three times with benzene, and stored in a $\mathrm{N}_{2}$-filled glovebox.

Vinyl boronic acid pinacol ester was purchased from Sigma-Aldrich and used without further purification. 
- General Procedure (I) for the Enantio- and Diastereoselective Bis-Borylation/Cyclization for [6,5]-fused ring systems and cyclopentane systems

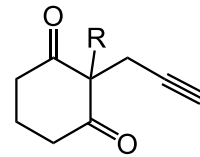

(1.0 equiv)

or

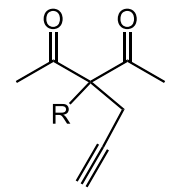

(1.0 equiv)

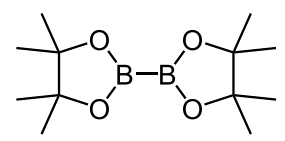

(2.2 equiv)

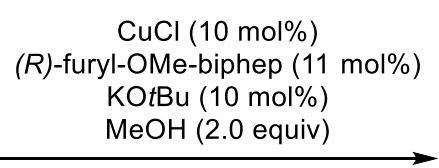

$\mathrm{THF}, 22^{\circ} \mathrm{C}, 18 \mathrm{~h}$

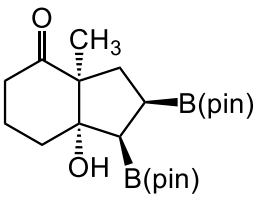

$\mathrm{R}=\mathrm{CH}_{3}$

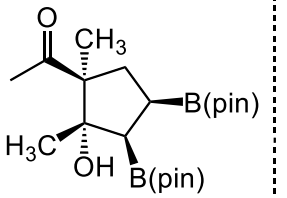

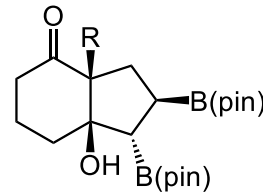

$R$ larger than $\mathrm{CH}_{3}$<smiles>[2H]C1(C(C)=O)CC(Br)C(Br)C1(C)O</smiles>

In a $\mathrm{N}_{2}$-filled glovebox, an $8 \mathrm{~mL}$ vial equipped with a magnetic stir bar was charged with

$\mathrm{CuCl}$ (1.0 mg, $0.010 \mathrm{mmol})$, (R)-furyl-OMe-biphep (6.0 mg, $0.011 \mathrm{mmol}), \mathrm{KO}$ Bu $(1.1 \mathrm{mg}, 0.010$ mmol), and $250 \mu \mathrm{L}$ of THF. The reaction was capped with a Teflon-lined lid and allowed to stir at room temperature for 30 minutes, after which time bis(pinacolato)diboron (55.9 $\mathrm{mg}, 0.22$ mmol) was added as a solid. The reaction turned dark brown immediately. After 15 minutes of stirring at room temperature, an additional $250 \mu \mathrm{L}$ of THF was added, followed immediately by neat diketone substrate $(0.10 \mathrm{mmol})$. The vial was sealed with electrical tape and removed from the glovebox. Dry $\mathrm{MeOH}(8.1 \mu \mathrm{L}, 0.20 \mathrm{mmol})$ was added by syringe under a $\mathrm{N}_{2}$ atmosphere. The reaction was stirred at $22{ }^{\circ} \mathrm{C}$ for 18 hours.

After 18 hours, the reaction was opened, quenched with $1 \mathrm{~mL}$ of saturated $\mathrm{NH}_{4} \mathrm{Cl}(a q)$, and stirred vigorously at $22{ }^{\circ} \mathrm{C}$ for 30 minutes. Ethyl acetate $(1 \mathrm{~mL})$ was added and the layers separated. The aqueous layer was extracted three times with ethyl acetate, and the combined organic extracts were dried over $\mathrm{MgSO}_{4}$, filtered, and concentrated in vacuo. NMR yield and diastereomeric ratios were determined by ${ }^{1} \mathrm{H}$ NMR, using hexamethyldisiloxane as an internal standard. Products were purified by flash silica gel chromatography. Subsequent analysis by HPLC or SFC provided enantiomeric ratios.

Note: Reactions were run using either $(R)$ or $(S)$-furyl-OMe-biphep, which were purchased from Strem. 
- General Procedure (II) for the Enantio- and Diastereoselective Bis-Borylation/Cyclization for $[5,5]$-fused ring systems

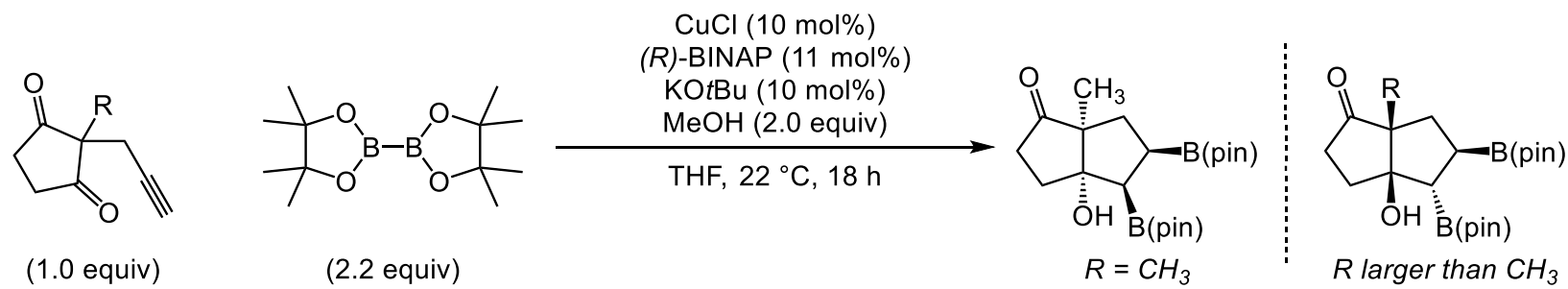

In an $\mathrm{N}_{2}$-filled glovebox, an $8 \mathrm{~mL}$ vial equipped with a magnetic stir bar was charged with $\mathrm{CuCl}$ (1.0 mg, $0.010 \mathrm{mmol})$, (R)-BINAP (6.8 mg, $0.011 \mathrm{mmol}), \mathrm{KO}$ Bu (1.1 mg, $0.010 \mathrm{mmol})$, and $250 \mu \mathrm{L}$ of THF. The reaction was capped with a Teflon-lined lid and allowed to stir at room temperature for 30 minutes, after which time bis(pinacolato)diboron (55.9 mg, $0.22 \mathrm{mmol}$ ) was added as a solid. The reaction turned dark brown immediately. After 15 minutes of stirring at room temperature, an additional $250 \mu \mathrm{L}$ of THF was added, followed immediately by neat diketone substrate $(0.10 \mathrm{mmol})$. The vial was sealed with electrical tape and removed from the glovebox. Dry $\mathrm{MeOH}(8.1 \mu \mathrm{L}, 0.20 \mathrm{mmol})$ was added by syringe under a $\mathrm{N}_{2}$ atmosphere. The reaction was stirred at $22{ }^{\circ} \mathrm{C}$ for 18 hours. Reactions were worked up according to General Procedure I.

\section{- Large Scale Synthesis of (5c)}

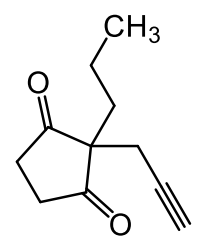

(1i)

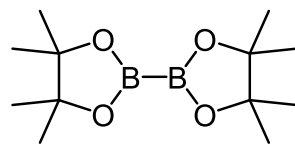

(2.2 equiv)

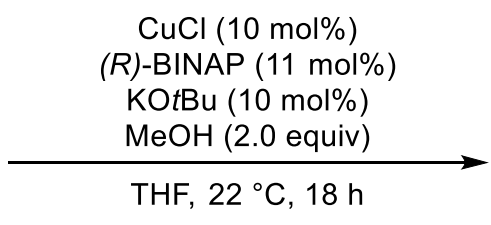

THF, $22^{\circ} \mathrm{C}, 18 \mathrm{~h}$

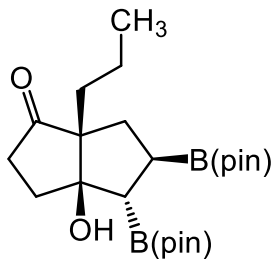

(5c)

(1.0 equiv)

In an $\mathrm{N}_{2}$-filled glovebox, a $100 \mathrm{~mL}$ round bottom flask equipped with a magnetic stir bar was charged with $\mathrm{CuCl}$ (48.6 mg, $0.491 \mathrm{mmol}, 10 \mathrm{~mol} \%$ ), (R)-BINAP (336.2 mg, $0.540 \mathrm{mmol}, 11$ $\mathrm{mol} \%), \mathrm{KO} t \mathrm{Bu}(55.1 \mathrm{mg}, 0.491 \mathrm{mmol}, 10 \mathrm{~mol} \%)$, and $12.3 \mathrm{~mL}$ of THF. The reaction was capped with a rubber septum and allowed to stir at room temperature for 30 minutes, after which time bis(pinacolato)diboron ( $2.74 \mathrm{~g}, 10.80 \mathrm{mmol}, 2.2$ equiv) was added as a solid. The reaction turned dark brown immediately. After 15 minutes of stirring at room temperature, an additional 8.3 $\mathrm{mL}$ of THF was added, followed immediately by a solution of diketone substrate $(875 \mathrm{mg}, 4.91$ mmol, 1.0 equiv, 1.23 M in THF). The flask was sealed with electrical tape and removed from the glovebox. Dry $\mathrm{MeOH}\left(398 \mu \mathrm{L}, 9.82 \mathrm{mmol}, 2.0\right.$ equiv) was added by syringe under a $\mathrm{N}_{2}$ 
atmosphere. After 18 hours, the reaction was opened, quenched with $25 \mathrm{~mL}$ of saturated $\mathrm{NH}_{4} \mathrm{Cl}$ $(a q)$, and stirred vigorously at $22{ }^{\circ} \mathrm{C}$ for 30 minutes. Ethyl acetate $(25 \mathrm{~mL})$ was added and the layers separated. The aqueous layer was extracted three times with ethyl acetate, and the combined organic extracts were dried over $\mathrm{MgSO}_{4}$, filtered, and concentrated in vacuo. Silica gel chromatography (15:1 hex:EtOAc $\rightarrow$ 10: 1 hex:EtOAc) afforded (5c) as a white powder (1.21 g, $57 \%$ yield, $>20: 1 \mathrm{dr}, 94: 6$ er).

\section{- Reaction Optimization}
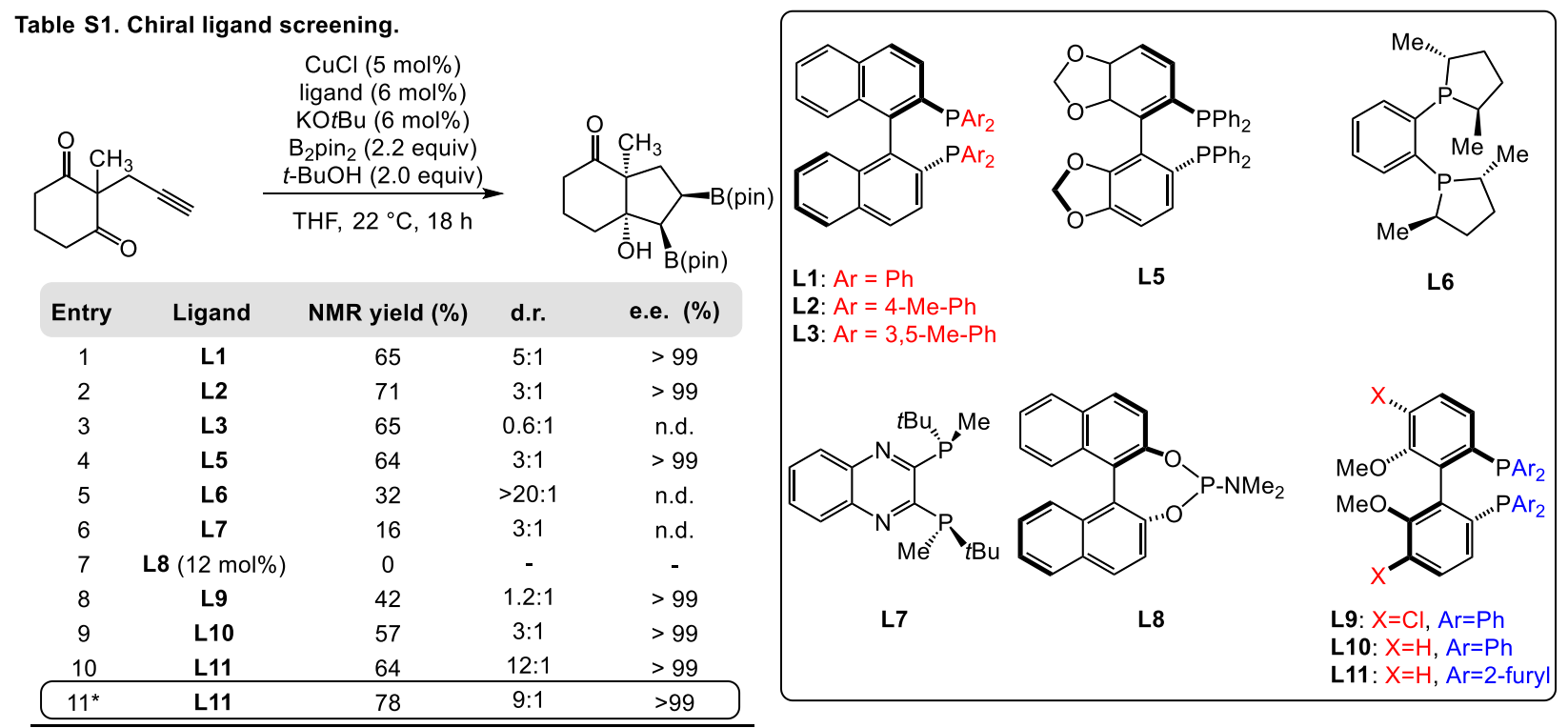

n.d. $=$ not determined

* $10 \mathrm{~mol} \% \mathrm{CuCl}, 11 \mathrm{~mol} \% \mathrm{~L} 11,10 \mathrm{~mol} \% \mathrm{KOtBu}$, and $\mathrm{MeOH}$ (2.0 equiv) instead of $t$-BuOH

Table S1: Screening of chiral phosphine ligands was performed on 2-methyl-2-propargyl-1,3cyclohexanedione. (R)-furyl-OMe-biphep (L11) afforded the product in good conversion and excellent diastereo- and enantioselectivity. Examination of the substrate scope later necessitated switching from $t$ - $\mathrm{BuOH}$ to $\mathrm{MeOH}$ to avoid large amounts of returned alkyne. 
- Vinyl boronic ester reactions

(1R,2R,3aS,7aS)-7a-hydroxy-3a-methyl-1,2-bis(4,4,5,5-tetramethyl-1,3,2-dioxaborolan-2yl)octahydro-4H-inden-4-one (3a)<smiles>CC1(C)OB(C2CC3(C)C(=O)CCC[C@]3(O)C2B2OC(C)(C)C(C)(C)O2)OC1(C)C</smiles>

(3a)

Racemic material: Diacel CHIRALPAK IC Column: 85:15 hexanes:iPrOH; $1.0 \mathrm{~mL} / \mathrm{min} ; 205$ nm.

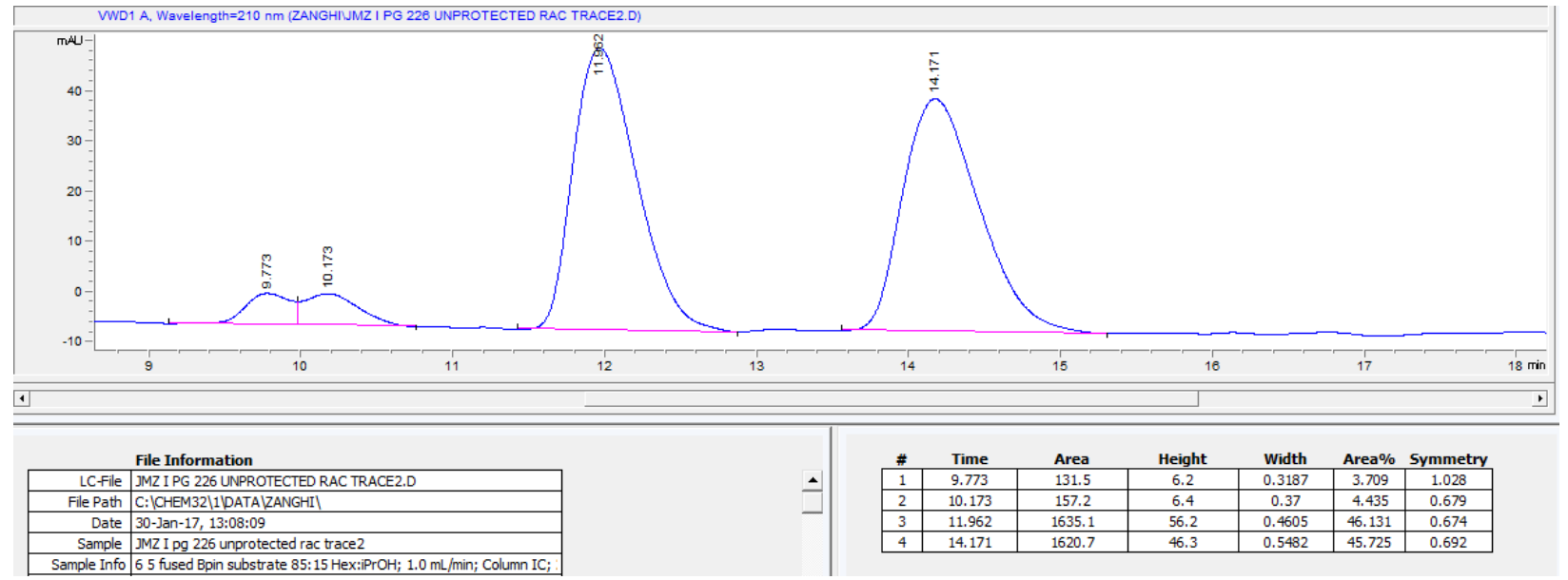

Enantioenriched material [(R)-BINAP]:

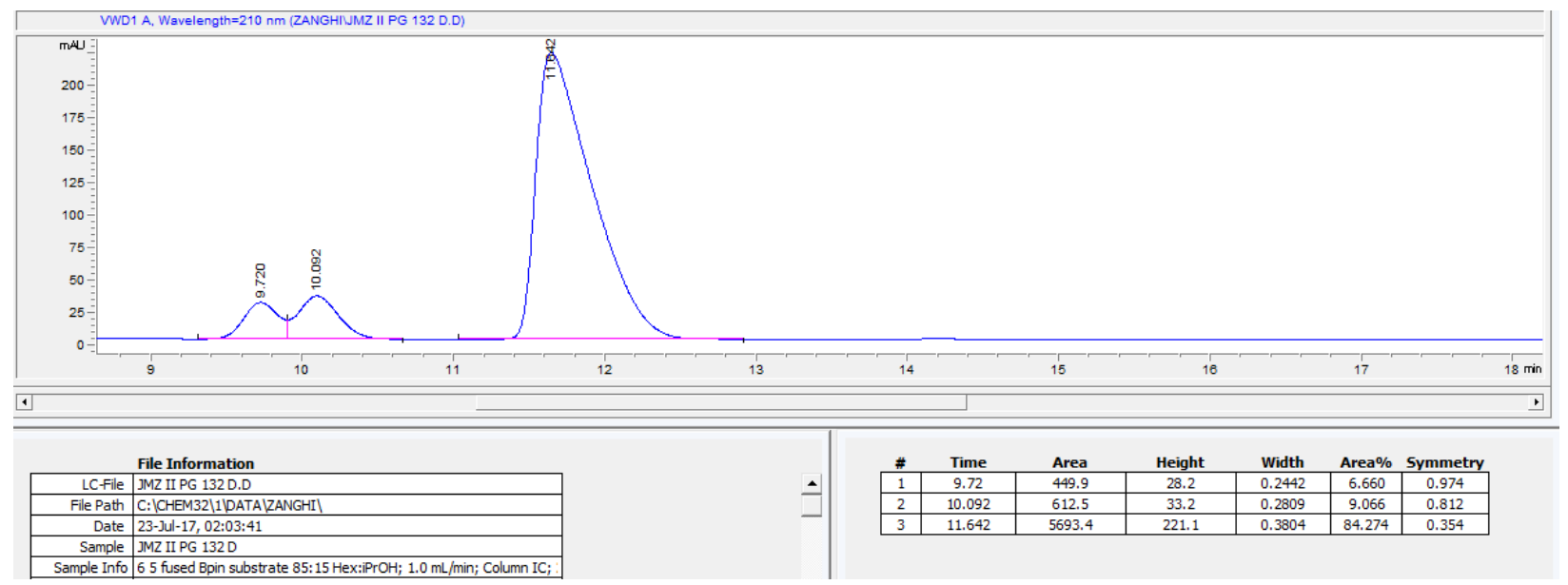


Enantioenriched material [(R)-furyl-OMe-biphep]:

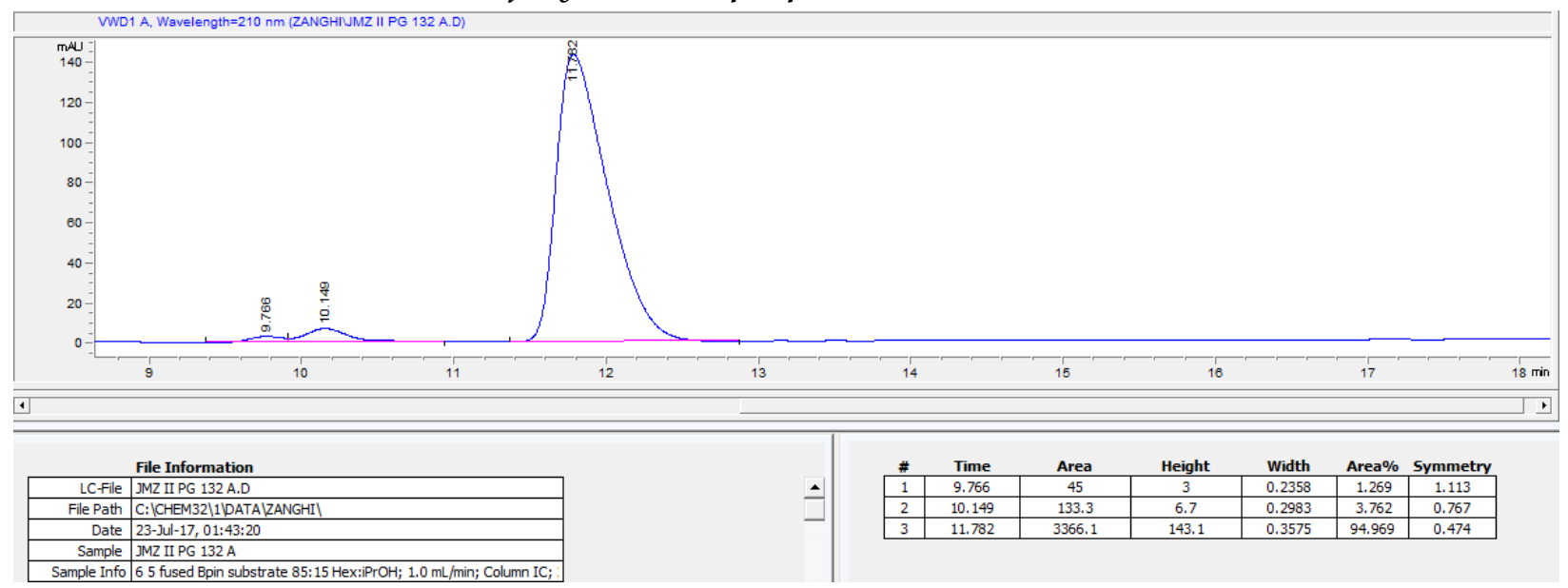

(3aR,4S,5R,6aR)-3a-hydroxy-6a-methyl-4,5-bis(4,4,5,5-tetramethyl-1,3,2-dioxaborolan-2yl)hexahydropentalen-1(2H)-one (5a)

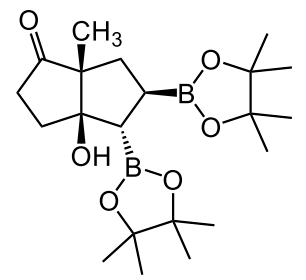

(5a)

Racemic material: Phenomenex Lux Cellulose-1 OD Column: 95:5 CO2:iPrOH; 1.0 mL/min; 205 nm.

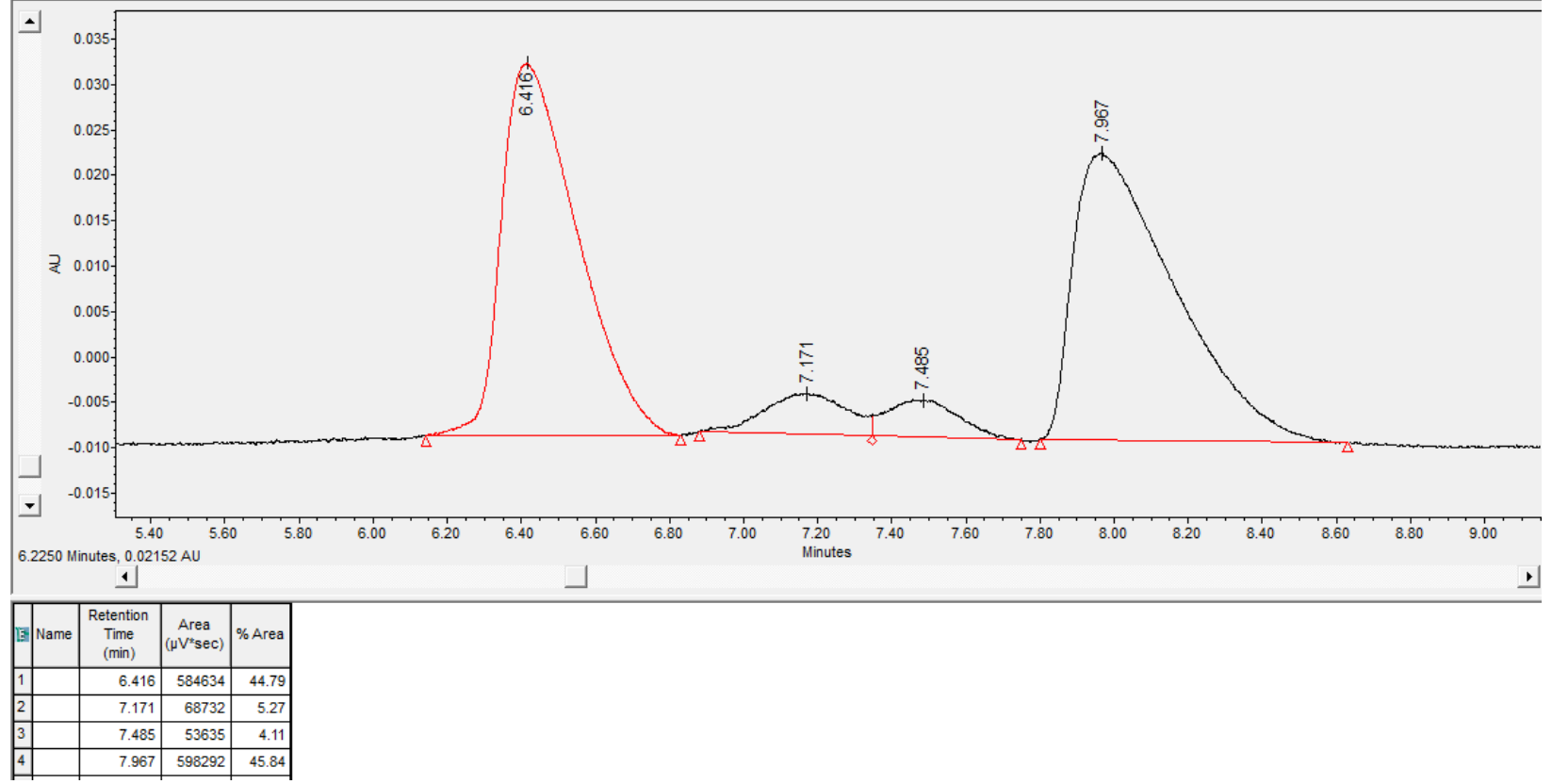


Enantioenriched material [(R)-BINAP]:

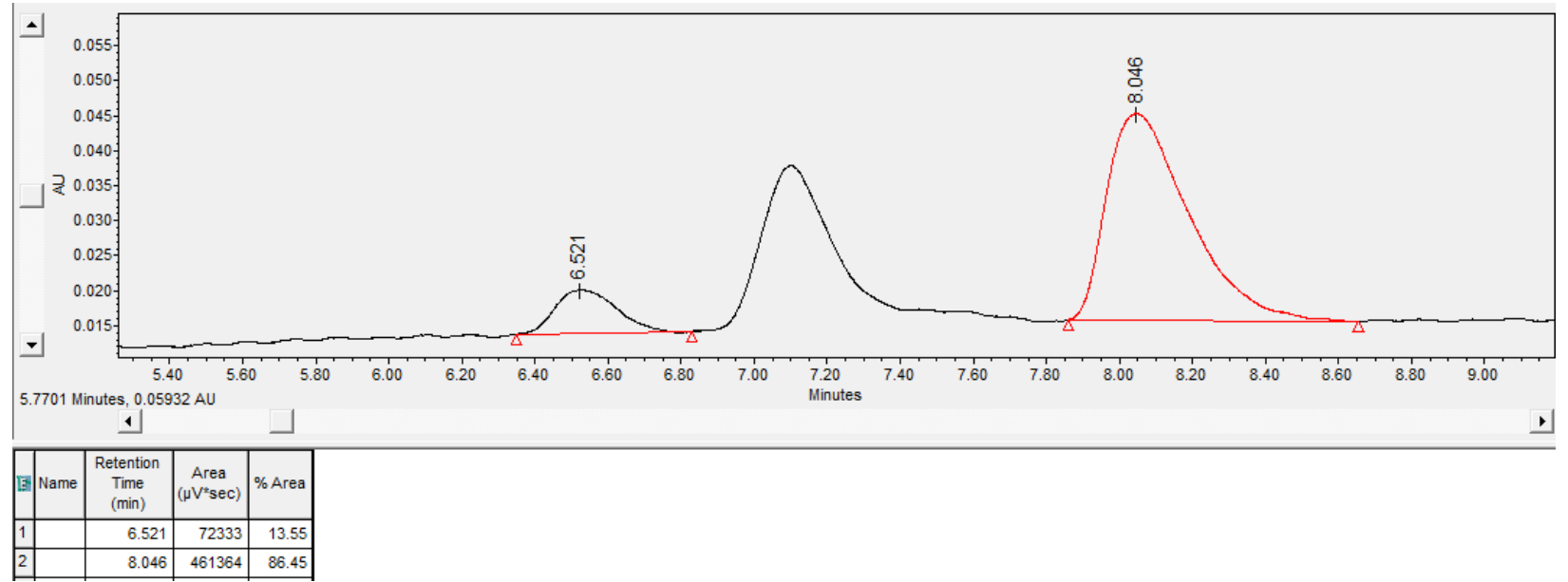

Enantioenriched material [(R)-furyl-OMe-biphep]:
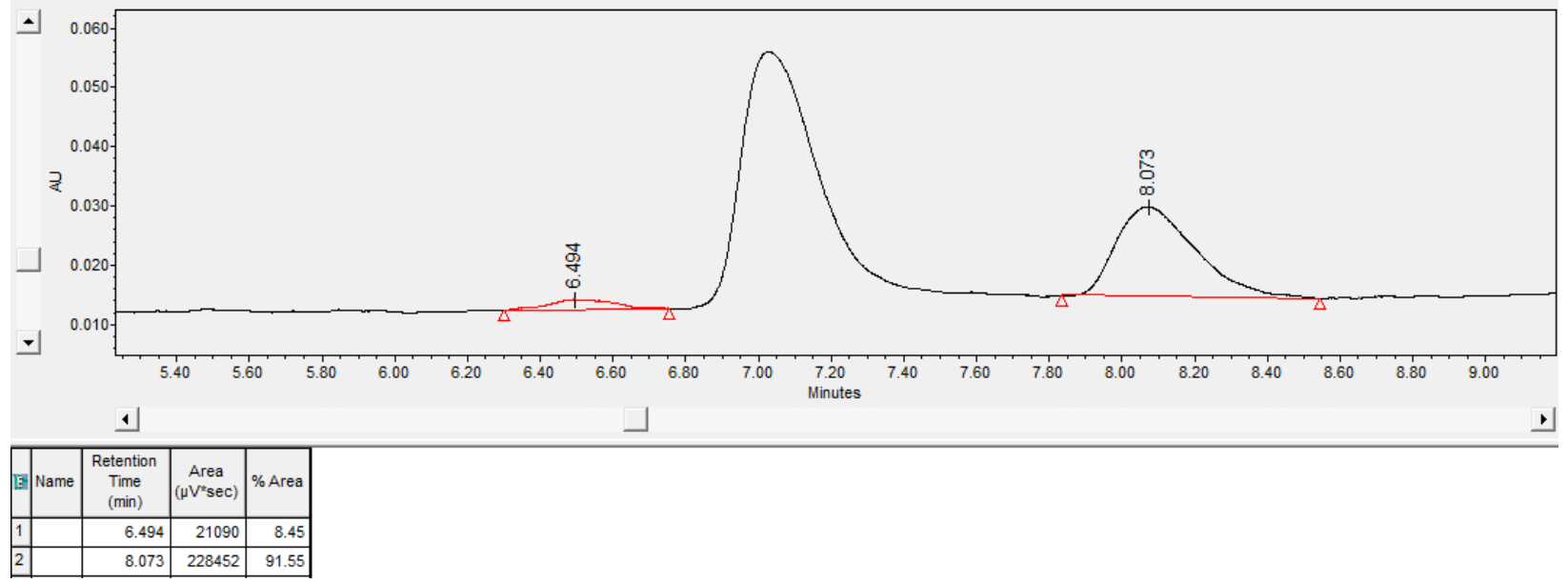

1-((1S,2S,3R,4R)-1,2-dimethyl-3,4-bis(4,4,5,5-tetramethyl-1,3,2-dioxaborolan-2-yl)-2-((4,4,5,5tetramethyl-1,3,2-dioxaborolan-2-yl)oxy)cyclopentyl)ethan-1-one (6a)

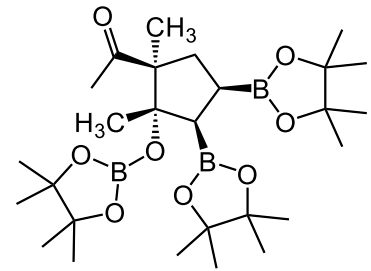

(6a) 
Racemic material: Diacel CHIRALPAK IC Column: 98:2 hexanes:iPrOH; 1.0 mL/min; 205 nm.

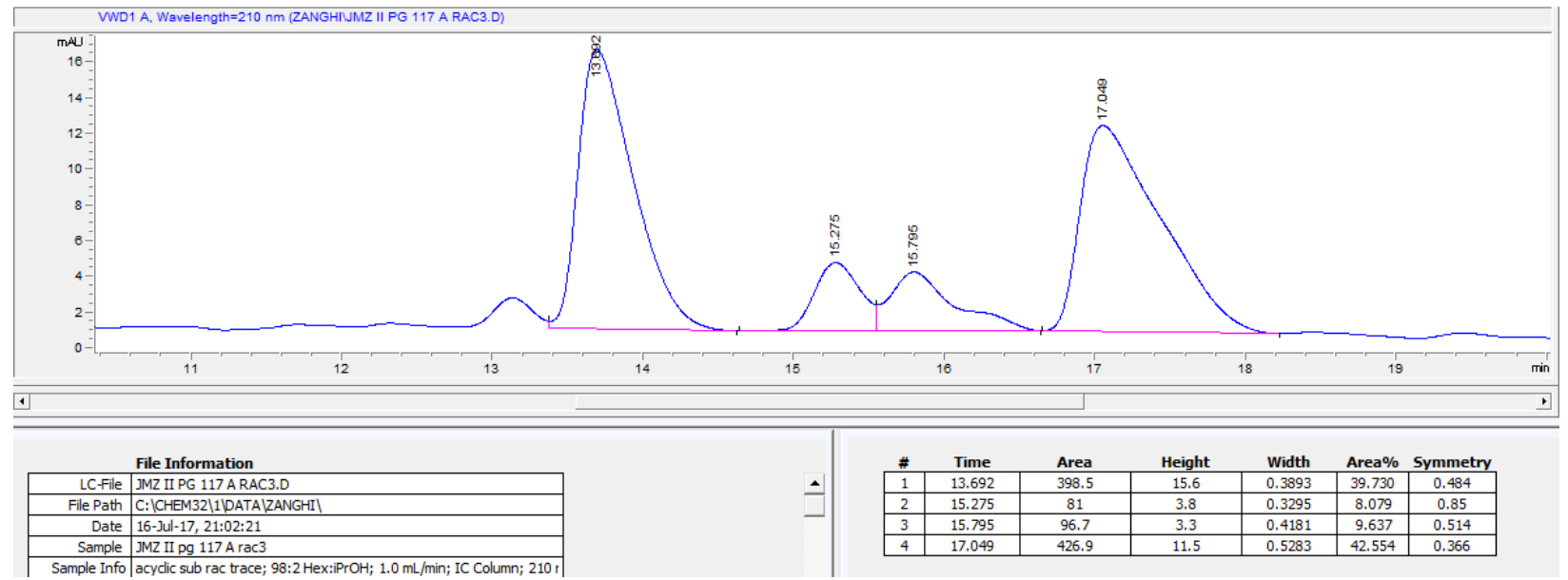

Enantioenriched material [(R)-BINAP]:

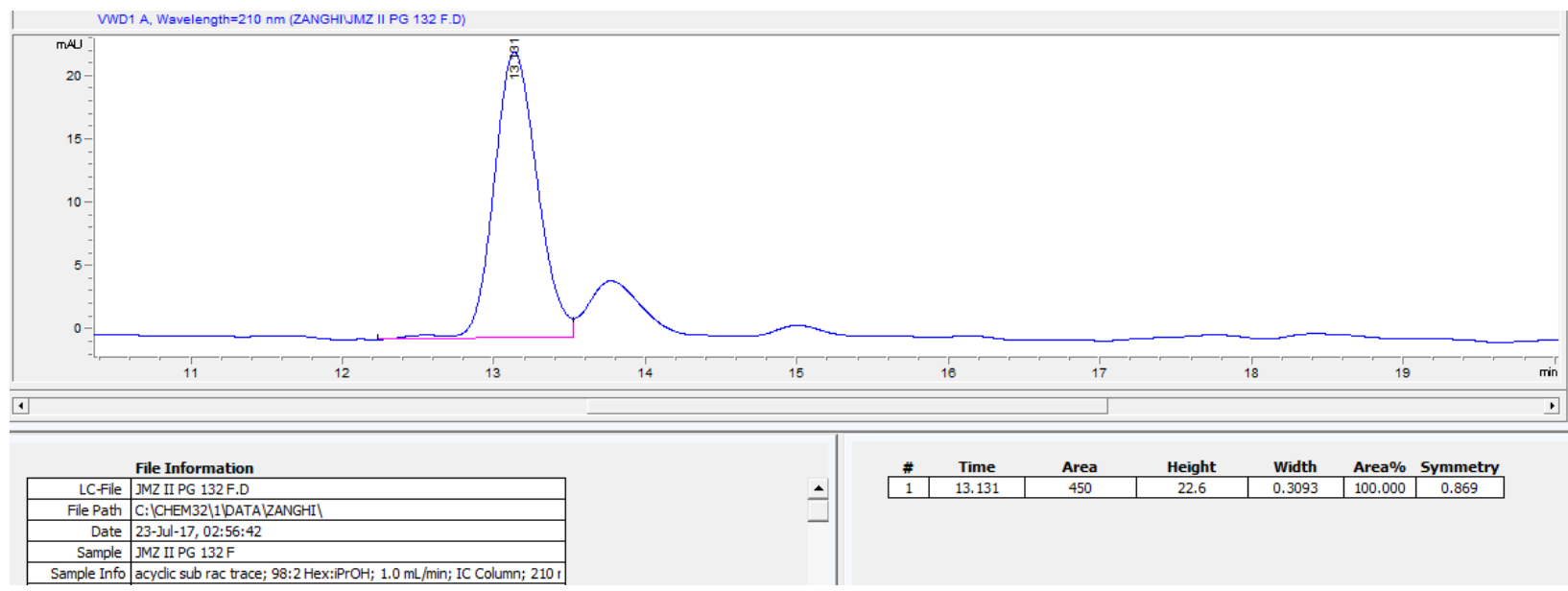

Note: Peak at $13.8 \mathrm{~min}$ thought to result from a mixture of $\mathrm{OBpin}$ and free $\mathrm{OH}$ products.

Enantioenriched material [(R)-furyl-OMe-biphep]:

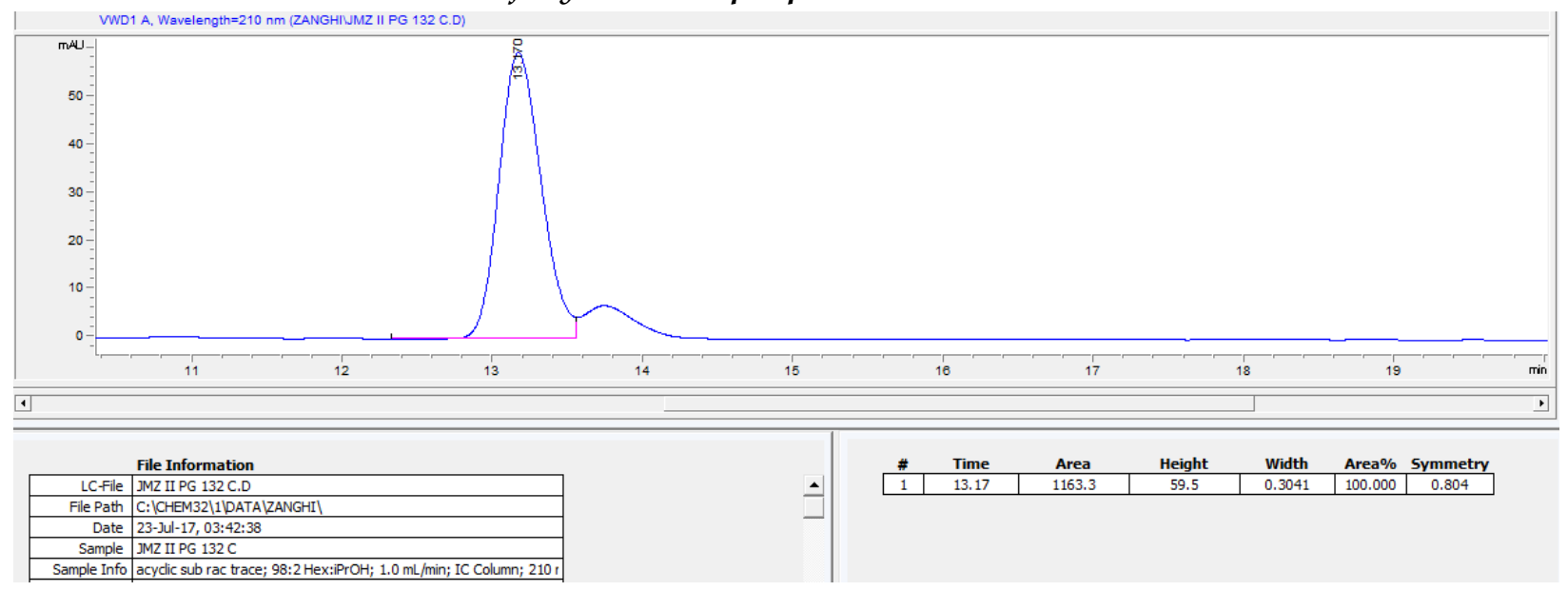

Note: Peak at 13.8 min thought to result from a mixture of OBpin and free $\mathrm{OH}$ products. 
Table S2. Studies from alkyne to access decalins.

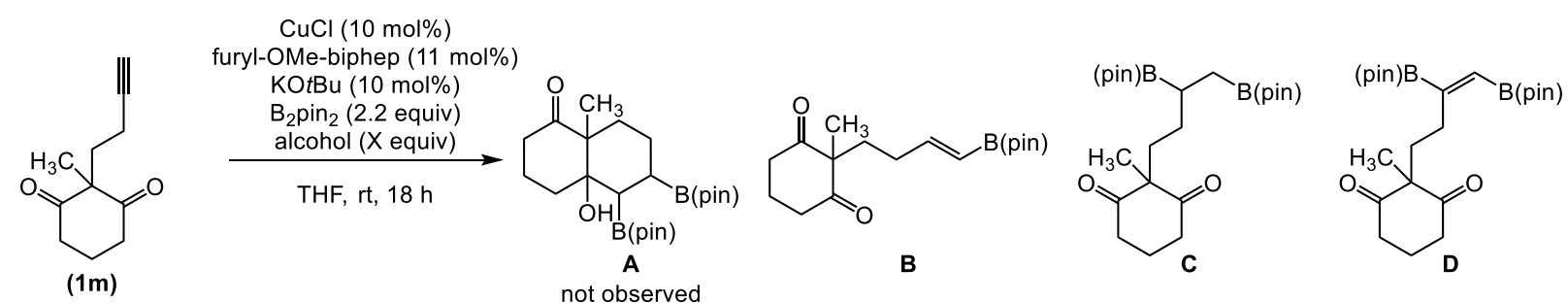

\begin{tabular}{ccccc} 
& & \multicolumn{3}{c}{ not observed } \\
Alcohol & Returned alkyne & B & C & D \\
MeOH (2 equiv) & $<5$ & $<5$ & 83 & 4 \\
$t$-BuOH (2 equiv) & 41 & 14 & 25 & 11 \\
$\mathrm{MeOH}$ (1 equiv) & 39 & 14 & 21 & 14
\end{tabular}

* Yield determined by ${ }^{1} \mathrm{H}$ NMR spectra of crude reactions with hexamethyldisiloxane as internal standard.

Table S3. Studies from vinyl boronic ester to access decalins.

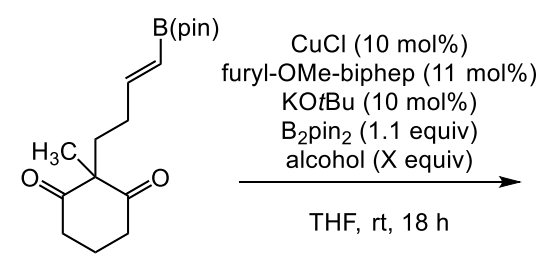

(1n)

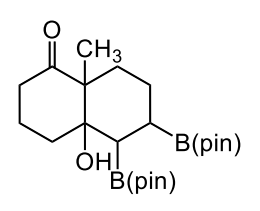

A

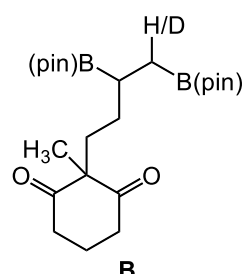

not observed

\begin{tabular}{cccc}
\hline Change in conditions & Returned vinyl Bpin & B & C \\
\hline MeOH (1.0 equiv) & 0 & 45 & 9 \\
$t$-BuOH (1.0 equiv) & 0 & 37 & 12 \\
$t$-BuOH (1.0 equiv)** & 0 & 50 & 18 \\
d4-methanol (1.0 equiv) & 17 & 24 & 4 \\
no alcohol & $\sim 80$ & $<5$ & 7 \\
BINAP as ligand (MeOH, 1 equiv) & 0 & 30 & 35 \\
\hline
\end{tabular}

* Yield determined by ${ }^{1} \mathrm{H}$ NMR spectra of crude reactions with hexamethyldisiloxane as internal standard.

** $t$ - $\mathrm{BuOH}$ added as a $1 \mathrm{M}$ solution in THF (10 $\times 10 \mathrm{uL}$ portions $)$ every $45 \mathrm{~min}$

Starting from alkyne $1 \mathrm{~m}$, standard catalytic conditions (2 equiv $\mathrm{MeOH}$ ) resulted in $83 \%$ NMR yield of the double hydroboration product C (Table S2). Attempts to slow down protonation with $t-\mathrm{BuOH}$ resulted in a large amount of returned alkyne and still significant double hydroboration. Attempts to start from the pre-formed vinyl boron (1n) also failed to provide product A (Table S3). Using d4-methanol to slow down protonation yielded a complex mixture where the product was not able to be identified either by crude NMR or in any fractions following silica gel chromatography. Switching to BINAP resulting in a large amount of a trisubstituted olefin D. Difficulties in the reaction likely result from the alkyl-Cu being farther away on a chain with more degrees of freedom (although 6-member ring formation was demonstrated in our previous work) and possible 1,3-diaxial strain which would raise the transition state energy for cyclization (1,3-diaxial strain not present in our previous work). ${ }^{1}$ 
- Substrate syntheses

2-methyl-2-propargyl-1,3-cyclohexanedione (1a)<smiles>C#CCC1(C)C(=O)CCCC1=O</smiles>

(1a)

(1a) was prepared according to a literature procedure. ${ }^{2}$

\section{2,5,5-trimethyl-2-(prop-2-yn-1-yl)cyclohexane-1,3-dione (1b)}

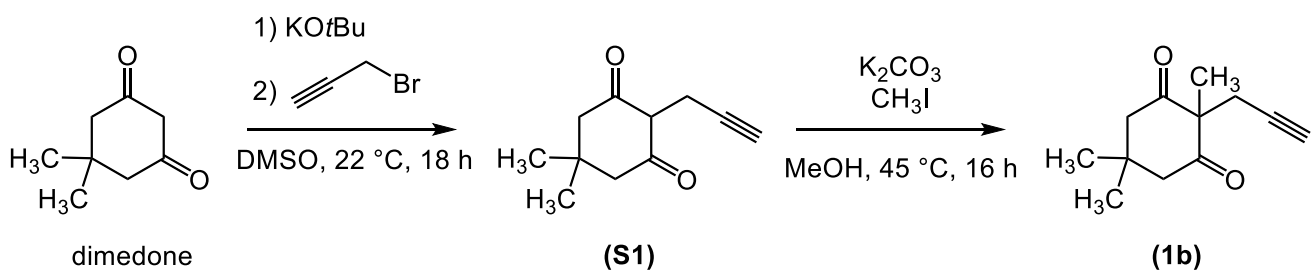

To an oven dried $100 \mathrm{~mL}$ round bottom flask was added dimedone $(2.00 \mathrm{~g}, 14.27 \mathrm{mmol}$, 1.18 equiv) followed by $30 \mathrm{~mL}$ of dry DMSO. KOtBu (1.31 g, $11.00 \mathrm{mmol}, 0.91$ equiv) was added at once, and the flask flushed with $\mathrm{N}_{2}$. After stirring for 45 minutes at $22{ }^{\circ} \mathrm{C}$, propargyl bromide (80 wt.\% in toluene) (1.35 mL, $12.09 \mathrm{mmol}, 1.0$ equiv) was added by syringe. The reaction was allowed to stir at $22{ }^{\circ} \mathrm{C}$ for 18 hours. The resulting orange solution was diluted with brine, and extracted with EtOAc $(3 \times 35 \mathrm{~mL})$. The combined organic extracts were dried over $\mathrm{MgSO}_{4}$, filtered, and concentrated in vacuo, giving (S1) as a yellow solid that was used without further purification.

To the crude solid was added $\mathrm{K}_{2} \mathrm{CO}_{3}(3.33 \mathrm{~g}$, $24.1 \mathrm{mmol}$, 2.0 equiv), $\mathrm{MeOH}(40 \mathrm{~mL})$, and MeI (3.75 mL, $60.2 \mathrm{mmol}, 5$ equiv) in a $100 \mathrm{~mL}$ flask. A reflux condenser was attached, and the mixture was heated at $45{ }^{\circ} \mathrm{C}$ for $16 \mathrm{~h}$. The reaction was cooled to room temperature and concentrated by rotary evaporation. The residue was dissolved in $50 \mathrm{~mL}$ EtOAc and extracted with $\mathrm{NaOH}(1.0 \mathrm{M}, 50 \mathrm{~mL})$. The organic layer was separated and the aqueous layer washed with EtOAc $(3 \times 50 \mathrm{~mL})$. The combined organic extracts were dried over $\mathrm{MgSO}_{4}$, filtered, and concentrated by rotary evaporation. The material was purified by silica gel chromatography (6:1 hex:EtOAc) to afford (1b) as a viscous yellow oil (344 mg, $1.79 \mathrm{mmol}, 15 \%$ over 2 steps).

${ }^{1} \mathrm{H}$ NMR (600 MHz, $\left.\mathrm{CDCl}_{3}\right): 2.71(\mathrm{~s}, 1 \mathrm{H}) ; 2.69$ (s, 1H); 2.61 (d, $\left.2.9 \mathrm{~Hz}, 2 \mathrm{H}\right) ; 2.56$ (s, 1H); 2.53 (s, $1 \mathrm{H}) ; 1.96$ (t, $2.6 \mathrm{~Hz}, 1 \mathrm{H}), 1.33$ (s, 3H); 1.06 (s, 3H); 0.98 (s, 3H). ${ }^{13} \mathrm{C}$ NMR (151 MHz, CDCl $): 208.5$, 80.6, 70.9, 63.4, 51.5, 30.8, 29.8, 27.4, 23.9, 22.9. HRMS (m/z): calcd for $\mathrm{C}_{12} \mathrm{H}_{17} \mathrm{O}_{2}{ }^{+}$: $193.1223\left(\mathrm{M}^{+} \mathrm{H}^{+}\right)$; found: 193.1222. IR (v/cm-1): $3280.3(w), 2957.3(w), 1730.8(\mathrm{~m}), 1698.0(\mathrm{~s}), 1457.0(\mathrm{w}), 1327.7(\mathrm{w})$. 


\section{2-prenyl-2-propargyl-1,3-cyclohexanedione (1c)}

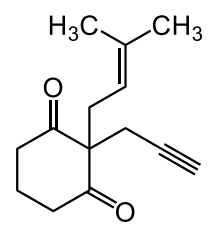

(1c)

Compound (1c) was prepared from 2-prenyl-1,3-cyclohexanedione, which was prepared according to a literature procedure. ${ }^{3}$ To a $50 \mathrm{~mL}$ round bottom flask equipped with a magnetic stir bar was added 2-prenyl-1,3-cyclohexanedione (1.00 g, $5.55 \mathrm{mmol}, 1.0$ equiv) and $\mathrm{K}_{2} \mathrm{CO}_{3}(1.38$ $\mathrm{g}$, $9.99 \mathrm{mmol}, 1.8$ equiv). The mixture was dissolved in $28 \mathrm{~mL}$ acetone and stirred for $10 \mathrm{~min}$ at room temperature. Propargyl bromide ( $80 \%$ wt. in toluene) $(1.24 \mathrm{~mL}, 11.10 \mathrm{mmol}, 2.0$ equiv) was added slowly. After 10 minutes, a reflux condenser was added and the mixture heated to $70{ }^{\circ} \mathrm{C}$ for $2 \mathrm{~h}$, at which point TLC showed the substrate was consumed. The reaction was cooled to room temperature, filtered through Celite, and concentrated by rotary evaporation. Column chromatography (5:1 hex:EtOAc) afforded 2-prenyl-2-propargyl-1,3-cyclohexanedione (1c) (829 $\mathrm{mg}, 3.80 \mathrm{mmol}, 68 \%$ yield). $\mathrm{R}_{\mathrm{f}}(4: 1$ hex:EtOAc $)=0.37$.

${ }^{1} \mathbf{H}$ NMR (600 MHz, CDCl $): 4.84(\mathrm{tt}, 7.7 \mathrm{~Hz}, 1.5 \mathrm{~Hz}, 1 \mathrm{H}) ; 2.61(\mathrm{~m}, 4 \mathrm{H}) ; 2.58$ (d, $\left.2.2 \mathrm{~Hz}, 2 \mathrm{H}\right) ; 2.42$ $(\mathrm{d}, 7.7 \mathrm{~Hz}, 2 \mathrm{H}) ; 1.99(\mathrm{~m}, 1 \mathrm{H}) ; 1.92(\mathrm{~m}, 1 \mathrm{H}) ; 1.90(\mathrm{t}, 2.6 \mathrm{~Hz}, 1 \mathrm{H}) ; 1.64(\mathrm{~s}, 3 \mathrm{H}) ; 1.52(\mathrm{~s}, 3 \mathrm{H}) .{ }^{13} \mathrm{C} \mathrm{NMR}$ (151 MHz, $\left.\mathrm{CDCl}_{3}\right):$ 209.7, 137.0, 117.0, 81.0, 70.4, 67.8, 39.8, 36.8, 26.0, 23.7, 17.9, 16.8. HRMS $(\mathrm{m} / \mathrm{z})$ : calcd for $\mathrm{C}_{14} \mathrm{H}_{19} \mathrm{O}_{2}{ }^{+}: 219.1380\left(\mathrm{M}+\mathrm{H}^{+}\right)$; found: 219.1378 . IR $\left(\mathrm{v} / \mathrm{cm}^{-1}\right): 3280.3(\mathrm{~m}), 2966.0(\mathrm{~m})$, $2917.7(\mathrm{~m}), 2360.4(\mathrm{w}), 2342.1(\mathrm{w}), 1725.0(\mathrm{~m}), 1698.0(\mathrm{~s}), 1325.8(\mathrm{w}), 1213.9(\mathrm{w})$.

\section{2-benzyl-2-propargyl-1,3-cyclohexanedione (1d)}

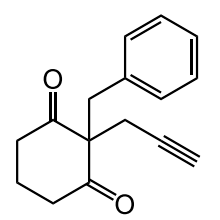

(1d)

Compound (1d) was prepared from 2-benzyl-1,3-cyclohexanedione, which was prepared according to a literature procedure. ${ }^{4}$ To an $8 \mathrm{~mL}$ vial with stir bar was added 2-benzyl1,3-cyclohexanedione (202 mg, $1.0 \mathrm{mmol}, 1.0$ equiv) and $\mathrm{K}_{2} \mathrm{CO}_{3}$ (166 mg, $1.2 \mathrm{mmol}, 1.2 \mathrm{equiv}$ ). Acetone $(5 \mathrm{~mL})$ was added and the reaction stirred for 5 minutes, followed by addition of propargyl bromide ( $80 \%$ wt. in toluene) $(223 \mu \mathrm{L}, 2.0 \mathrm{mmol}, 2.0$ equiv). The vial was sealed and heated at $70{ }^{\circ} \mathrm{C}$ for 1 hour. The reaction was cooled to room temperature, filtered through Celite, and concentrated by rotary evaporation. Silica gel chromatography (5:1 hex:EtOAc) afforded 2-benzyl-2-propargyl-1,3-cyclohexanedione (1d) (182 mg, $0.76 \mathrm{mmol}, 76 \%$ yield) as a 
pale yellow oil. Upon azeotropic drying with benzene, the compound crystalized as a white solid. The compound is consistent with literature characterization. ${ }^{5}$

\section{2-(prop-2-yn-1-yl)-2-(thiophen-3-ylmethyl)cyclohexane-1,3-dione (1e)}<smiles>CCOC(=O)C1=C(C)NC(C)=C(C(=O)OCC)C1</smiles><smiles>O=C1CCCC(=O)C1</smiles>

(1.0 equiv)
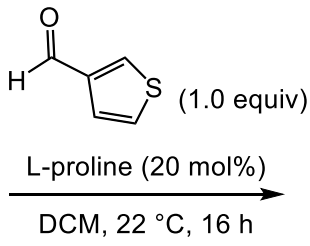

DCM, $22{ }^{\circ} \mathrm{C}, 16 \mathrm{~h}$

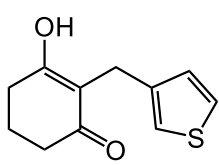

(S2)

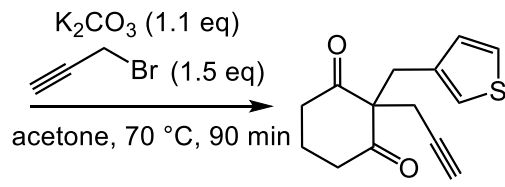

(1e)

To an $8 \mathrm{~mL}$ vial with stir bar was added 1,3-cyclohexanedione (350 mg, $3.12 \mathrm{mmol}, 1.0$ equiv) and Hantzsch ester (790 mg, $3.12 \mathrm{mmol}, 1.0$ equiv). DCM (6 mL) was added, followed by addition of 3-formylthiophene ( $301 \mu \mathrm{L}, 3.43 \mathrm{mmol}, 1.1$ equiv). L-proline (72 mg, $0.62 \mathrm{mmol}, 20$ mol\%) was added, and the reaction heated at $40{ }^{\circ} \mathrm{C}$ for $16 \mathrm{~h}$. The reaction was cooled to room temperature and concentrated by rotary evaporation. The residue was suspended in $\mathrm{NaOH}$ (aq) $(1 \mathrm{M}, 30 \mathrm{~mL})$ and filtered through cotton. The filtrate was cooled to $0{ }^{\circ} \mathrm{C}$, and the product precipitated by addition of glacial acetic acid $(\sim 1.5 \mathrm{~mL})$ till the suspension had $\mathrm{pH} \sim 3$. The solid was collected on a fritted funnel, washed with a small amount of cold DI water, and dried in vacuo yielding (S2) (400 mg, $1.92 \mathrm{mmol}, 62 \%$ yield) as a light yellow solid that was used without further purification.

${ }^{1}$ H NMR (600 MHz, d6-DMSO): 10.57 (br s, 1H); 7.32 (dd, $\left.5.1 \mathrm{~Hz}, 3.3 \mathrm{~Hz}, 1 \mathrm{H}\right) ; 6.95$ (d, $1.8 \mathrm{~Hz}$, $1 \mathrm{H}) ; 6.89$ (d, $4.8 \mathrm{~Hz}, 1 \mathrm{H}) ; 3.36$ (br s, 2H); 2.35 (br s, 4H), 1.85 (p, $6.2 \mathrm{~Hz}, 2 \mathrm{H}) .{ }^{13} \mathrm{C}$ NMR (151 MHz, d6-DMSO): 141.9, 128.7, 124.9, 119.9, 113.8, 22.1, 20.5. HRMS (m/z): calcd for $\mathrm{C}_{11} \mathrm{H}_{11} \mathrm{O} 2 \mathrm{~S}: 207.0485$

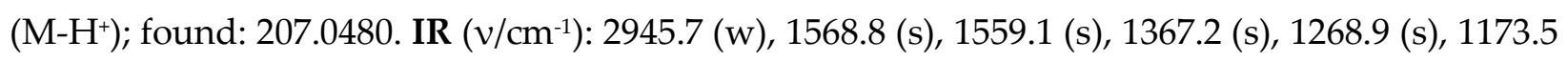
(m), 1007.6 (s).

Intermediate (S2) (300 mg, $1.44 \mathrm{mmol}, 1.0$ equiv) was added to an $8 \mathrm{~mL}$ vial equipped with a stir bar. Acetone $(6 \mathrm{~mL})$ was added, followed by $\mathrm{K}_{2} \mathrm{CO}_{3}(239 \mathrm{mg}, 1.73 \mathrm{mmol}, 1.2 \mathrm{equiv})$. After 10 minutes of stirring, propargyl bromide ( $80 \%$ wt. in toluene) ( $241 \mu \mathrm{L}, 2.16 \mathrm{mmol}, 1.5$ equiv) was added. The reaction was sealed, and heated at $70{ }^{\circ} \mathrm{C}$ for 90 minutes. The reaction was cooled to room temperature, filtered through Celite, and concentrated by rotary evaporation. Silica gel chromatography (6:1 hex:EtOAc) afforded 2-(prop-2-yn-1-yl)-2(thiophen-3-ylmethyl)cyclohexane-1,3-dione (1e) (217 mg, $0.88 \mathrm{mmol}, 61 \%$ yield) as a yellow oil.

${ }^{1} \mathbf{H}$ NMR (600 MHz, CDCl $): 7.20(\mathrm{dd}, 4.8 \mathrm{~Hz}, 2.9 \mathrm{~Hz}, 1 \mathrm{H}) ; 6.88(\mathrm{dd}, 2.6 \mathrm{~Hz}, 0.7 \mathrm{~Hz}, 1 \mathrm{H}), 6.73(\mathrm{dd}$, $5.1 \mathrm{~Hz}, 1.1 \mathrm{~Hz}, 1 \mathrm{H}) ; 3.08$ (s, 2H); 2.67 (d, $2.6 \mathrm{~Hz}, 2 \mathrm{H}) ; 2.52(\mathrm{~m}, 2 \mathrm{H}) ; 2.25(\mathrm{~m}, 2 \mathrm{H}) ; 1.99$ (t, $2.6 \mathrm{~Hz}$, 1H); 1.82 (m, 1H); 1.24 (m, 1H). ${ }^{13} \mathrm{C}$ NMR (151 MHz, $\left.\mathrm{CDCl}_{3}\right)$ : 211.1, 135.8, 129.0, 126.1, 123.8, 80.0, 
71.3, 67.4, 40.8, 38.2, 26.6, 15.5. HRMS ( $\mathrm{m} / \mathrm{z})$ : calcd for $\mathrm{C}_{14} \mathrm{H}_{15} \mathrm{O}_{2} \mathrm{~S}^{+}$: $247.0787\left(\mathrm{M}^{+} \mathrm{H}^{+}\right)$; found: 247.0786. IR (v/cm-1): $3283.2(\mathrm{w}), 1721.21(\mathrm{~m}), 1697.0(\mathrm{~s}), 1340.3(\mathrm{w}), 1015.3(\mathrm{w}), 792.6(\mathrm{w})$.

\section{2-methyl-2-propargyl-1,3-cyclopentanedione (1g)}

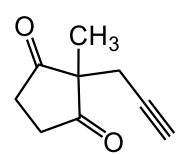

(1g)

Compound (1g) was prepared according to a known procedure. ${ }^{6}$

\section{2-allyl-2-propargyl-1,3-cyclopentanedione (1h)}

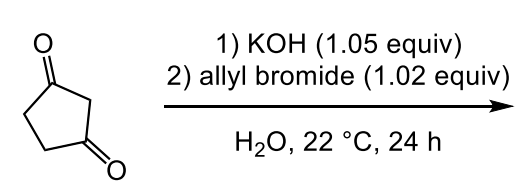

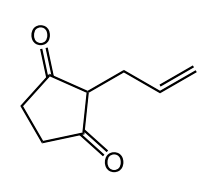

(S3)
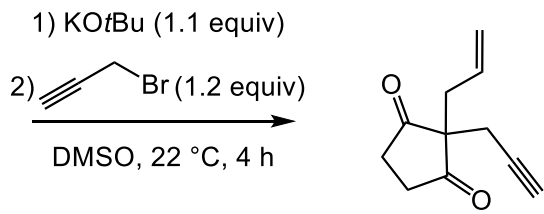

(1h)

To a $100 \mathrm{~mL}$ round bottom flask with a magnetic stir bar was added 1,3cyclopentanedione $(2.0 \mathrm{~g}, 20.40 \mathrm{mmol}, 1.00$ equiv), followed by $\mathrm{KOH}(a q)(0.31 \mathrm{M}, 70 \mathrm{~mL}, 21.4$ mmol, 1.05 equiv). After 30 minutes of stirring at $22{ }^{\circ} \mathrm{C}$, allyl bromide (1.8 mL, $20.83 \mathrm{mmol}, 1.02$ equiv) was added by syringe. The reaction was stirred at $22{ }^{\circ} \mathrm{C}$ for $24 \mathrm{~h}$, then the solvent removed by rotary evaporation. ${ }^{1} \mathrm{H}$ NMR of the crude residue showed a 2:1 ratio of $\mathrm{C}: \mathrm{O}-$ alkylation. Purification by silica gel chromatography (hex:EtOAc) afforded (S3) as the pure Calkylated product (380 mg, $2.75 \mathrm{mmol}, 13 \%$ yield). Compound (1h) was then synthesized according to a known procedure. ${ }^{7}$ Both (S3) and (1h) were consistent with literature NMR spectra. $^{7}$

\section{2-n-propyl-2-propargyl-1,3-cyclopentanedione (1i)}

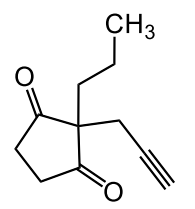

(1i)

Compound (1i) was prepared from the intermediate 2- $n$-propyl-1,3-cyclopentanedione which was prepared using a known literature protocol. ${ }^{8}$ The Hantzsch ester used in the preparation of 2- $n$-propyl-1,3-cyclopentanedione was prepared according to a known procedure. ${ }^{7}$

2- $n$-propyl-1,3-cyclopentanedione ( $2.0 \mathrm{~g}, 14.28 \mathrm{mmol}, 1.0$ equiv) was added to a $100 \mathrm{~mL}$ round bottom flask. A solution of $\mathrm{KOH}(a q)(0.31 \mathrm{M}, 881 \mathrm{mg}, 15.71 \mathrm{mmol}, 1.1$ equiv) was added 
and the solution allowed to stir at $22{ }^{\circ} \mathrm{C}$ for $1 \mathrm{~h}$. Propargyl bromide (80\% wt. in toluene) (3.18 $\mathrm{mL}, 28.56 \mathrm{mmol}, 2.0$ equiv) was added by syringe. The reaction was heated at $80{ }^{\circ} \mathrm{C}$ for $24 \mathrm{~h}$, then diluted with EtOAc (100 mL). $1 \mathrm{M} \mathrm{NaOH}(50 \mathrm{~mL})$ was added, and the layers were separated. The aqueous layer was extracted with EtOAc $(3 \times 100 \mathrm{~mL})$. The combined organic extracts were dried over $\mathrm{MgSO}_{4}$, filtered, and concentrated by rotary evaporation. Purification by silica gel chromatography (5:1 hex: EtOAc) afforded (1i) as a yellow viscous oil (1.65 g, 9.26 mmol, 65\% yield). ${ }^{1} \mathrm{H}$ NMR was consistent with a known literature spectrum. ${ }^{9}$

\section{3-methyl-3-propargyl-2,4-pentanedione (1j)}

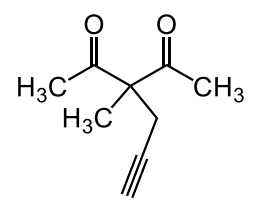

(1j)

Compound (1j) was prepared according a known procedure. ${ }^{10}$

\section{3-propargyl-2,4-pentanedione (S4)}

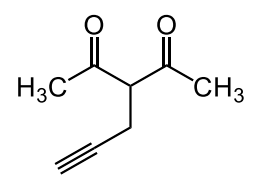

(S4)

A 2 L oven-dried 3-neck round bottom flask with a stir bar was evacuated and refilled with $\mathrm{N}_{2}$. This process was repeated twice more. $\mathrm{NaH}(60 \%$ dispersion in mineral oil, $11.99 \mathrm{~g}$ dispersion, $300 \mathrm{mmol}$ ) was added quickly. The flask was evacuated once more and refilled with N2. $800 \mathrm{~mL}$ of dry THF was added. After 15 minutes of rigorous stirring, a solution of 2,4pentanedione $(30.0 \mathrm{~g}, 300 \mathrm{mmol}, 1.5 \mathrm{M}$ in THF) was added in $50 \mathrm{~mL}$ portions by syringe. After the addition was finished, the flask was sonicated for 5 minutes, followed by 10 minutes of stirring, followed by sonication for 10 minutes, and finally 90 minutes of rigorous stirring, after which no further $\mathrm{H}_{2}$ emission was observed. An oven dried addition funnel was added quickly to the flask. Propargyl bromide ( $80 \% \mathrm{wt}$. solution in toluene, $33.4 \mathrm{~mL}, 300 \mathrm{mmol})$ was added to the addition funnel, and this solution was diluted with $100 \mathrm{~mL}$ dry THF. The reaction was cooled to $0{ }^{\circ} \mathrm{C}$, and the propargyl bromide solution was added over a period of 10 minutes. After the addition was finished, the ice bath was removed, and the reaction stirred at $22{ }^{\circ} \mathrm{C}$ for 42 hours. The reaction was then cooled to $0{ }^{\circ} \mathrm{C}$ and diluted with EtOAc (400 mL). $1 \mathrm{M} \mathrm{HCl}(a q)$ (300 mL) was then added. The organic layer was separated, then split into three approximately equal volumes. Each organic portion was extracted with $150 \mathrm{~mL}$ brine, dried over $\mathrm{MgSO}_{4}$, 
filtered, and the portions concentrated together in vacuo. The residue was purified by column chromatography (7:3 hex:DCM) to afford 3-propargyl-2,4-pentanedione (S4) as a yellow oil (9.75 g, $70.6 \mathrm{mmol}, 24 \%$ yield). NMR characterization was consistent with the literature. ${ }^{11}$

\section{3-ethyl-3-propargyl-2,4-pentanedione (1k)}

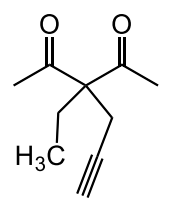

(1k)

Compound (1k) was prepared according to a known literature procedure. ${ }^{12}$

3-prenyl-3-propargyl-2,4-pentanedione (11)

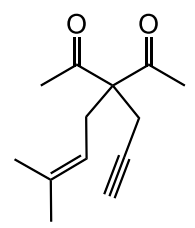

(11)

To an oven dried $50 \mathrm{~mL}$ round bottom with a stir bar was quickly added 3-propargyl2,4-pentanedione (S4) (1.00 g, $7.24 \mathrm{mmol}, 1$ equiv). The flask was evacuated and backfilled with $\mathrm{N}_{2}$, followed by addition of $29 \mathrm{~mL}$ dry THF. $\mathrm{NaH}$ (60\% dispersion in mineral oil) (304 mg dispersion, $7.60 \mathrm{mmol}, 1.05$ equiv) was added at once as a solid, and the reaction quickly resealed. After 45 minutes of stirring at $22^{\circ} \mathrm{C}$, 3,3-dimethylallyl bromide (1.67 mL, $14.48 \mathrm{mmol}$, 2.0 equiv) was added by syringe. The reaction stirred at $22{ }^{\circ} \mathrm{C}$ for $12 \mathrm{~h}$. The reaction was diluted with EtOAc $(30 \mathrm{~mL})$, and a base extraction was performed with $30 \mathrm{~mL} 1 \mathrm{M} \mathrm{NaOH}(a q)$. The basic aqueous layer was extracted with EtOAc $(3 \times 30 \mathrm{~mL})$. The combined organic phases were washed with brine $(50 \mathrm{~mL})$, dried over $\mathrm{MgSO}_{4}$, filtered, and concentrated in vacuo. The residue was purified by silica gel chromatography (15:1 hex:EtOAc $\rightarrow$ 7:1 hex:EtOAc) to give 3-prenyl-3propargyl-2,4-pentanedione (11) (450 mg, $2.18 \mathrm{mmol}, 30 \%$ yield) as a clear, colorless oil. $\mathrm{R}_{\mathrm{f}}=0.42$ (10:1 hex:EtOAc).

${ }^{1} \mathbf{H}$ NMR (600 MHz, $\left.\mathrm{CDCl}_{3}\right): 4.72$ (tq, $\left.7.3 \mathrm{~Hz}, 1.5 \mathrm{~Hz}, 1 \mathrm{H}\right) ; 2.80(\mathrm{~d}, 7.5 \mathrm{~Hz}, 2 \mathrm{H}) ; 2.74(\mathrm{~d}, 2.5 \mathrm{~Hz}$, 2H); 2.14 (s, 6H); 1.99 (t, $2.5 \mathrm{~Hz}, 1 \mathrm{H}) ; 1.68$ (m, 6H). $\left.{ }^{13} \mathrm{C} \mathrm{NMR} \mathrm{(151} \mathrm{MHz,} \mathrm{CDCl}\right)$ : 204.9, 137.3, $116.8,80.0,71.8,70.6,29.5,26.9,26.2,20.8,18.2$. HRMS $(\mathrm{m} / \mathrm{z})$ : calcd for $\mathrm{C}_{13} \mathrm{H}_{19} \mathrm{O}_{2}{ }^{+}: 207.1380$

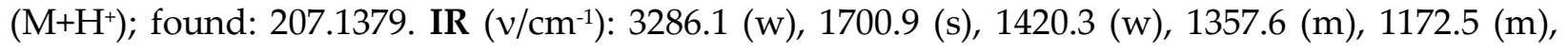
$1151.3(\mathrm{~m}), 646.0(\mathrm{w})$. 


\section{2-(but-3-yn-1-yl)-2-methylcyclohexane-1,3-dione (1m) and (E)-2-methyl-2-(4-(4,4,5,5- tetramethyl-1,3,2-dioxaborolan-2-yl)but-3-en-1-yl)cyclohexane-1,3-dione (1n)}

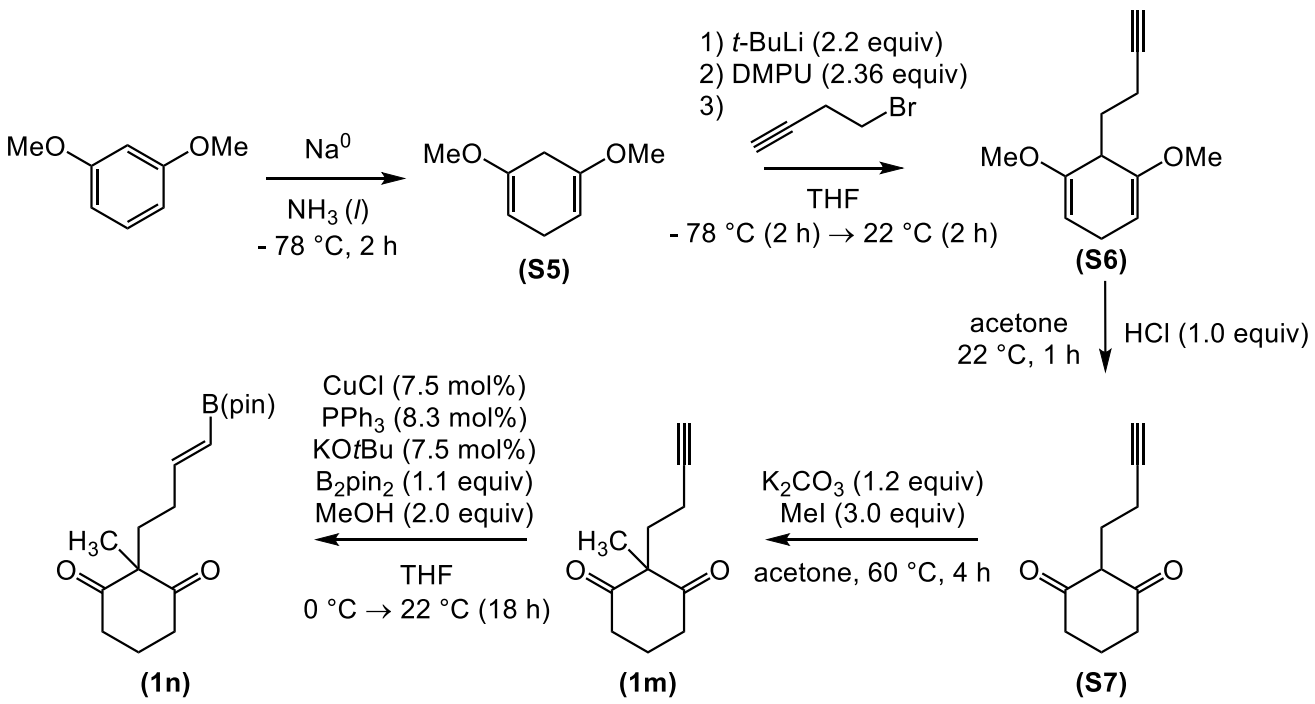

1,5-dimethoxycyclohexa-1,4-diene (S5) was prepared according to a known procedure. ${ }^{7}$

Synthesis of (S6): To a $100 \mathrm{~mL}$ flame dried round bottom flask with stir bar was added dry THF (40 mL) and the solvent cooled to $-78^{\circ} \mathrm{C}$. Carefully, tert-BuLi (1.37 $\mathrm{M}$ in pentane) (11.5 $\mathrm{mL}, 15.7 \mathrm{mmol}, 2.20$ equiv) was added dropwise, generating a light yellow solution. 1,5dimethoxycyclohexa-1,4-diene (1.00 g, $7.13 \mathrm{mmol}, 1.0$ equiv) was added dropwise neat. After 1 $\mathrm{h}$ of stirring at $-78{ }^{\circ} \mathrm{C}, 1,3$-dimethyl-3,4,5,6-tetrahydro-2(1H)-pyrimidinone (DMPU) (2.04 $\mathrm{mL}$, $16.84 \mathrm{mmol}, 2.36$ equiv) was added dropwise, resulting in an orange solution. After 10 minutes, 4-bromobut-1-yne (1.34 mL, $14.3 \mathrm{mmol}, 2.0$ equiv) was added dropwise and the solution stirred at $-78{ }^{\circ} \mathrm{C}$ for $2 \mathrm{~h}$. The solution was allowed to warm to room temperature and stirred a further $2 \mathrm{~h}$. The reaction was then opened and carefully diluted with $\mathrm{Et}_{2} \mathrm{O}(25 \mathrm{~mL})$ and saturated brine $(25 \mathrm{~mL})$. The mixture was transferred to a separatory funnel and the aqueous layer was extracted with $\mathrm{Et}_{2} \mathrm{O}(3 \times 25 \mathrm{~mL})$. The combined organic phases were dried over $\mathrm{MgSO}_{4}$ and concentrated by rotary evaporation. The residue was dissolved in 50:1 hexanes: $\mathrm{Et}_{2} \mathrm{O}$ and subjected to a short silica gel plug. The silica gel was washed liberally with 50:1 hex: $\mathrm{EtO}_{2}$ and the filtrate concentrated by rotary evaportation, affording 6-(but-3-yn-1-yl)-1,5dimethoxycyclohexa-1,4-diene (S6) as a clear, sweet-smelling oil (1.24 g, $6.45 \mathrm{mmol}$, 90\% yield).

Synthesis of (S7): 6-(but-3-yn-1-yl)-1,5-dimethoxycyclohexa-1,4-diene (S6) (1.24 g, 6.45 mmol, 1.0 equiv) was dissolved in $\mathrm{N}_{2}$-sparged acetone $(29 \mathrm{~mL})$. $\mathrm{N}_{2}$-sparged $1 \mathrm{M} \mathrm{HCl}(\mathrm{aq})(6.45$ $\mathrm{mL}, 1.0$ equiv) was added over $1 \mathrm{~min}$, and the solution stirred at $22^{\circ} \mathrm{C}$ for $1 \mathrm{~h}$, at which point TLC confirmed complete consumption of diene (S6). The reaction was then concentrated by rotary evaporation. The resulting white solid was dried in vacuo, then washed with hexanes $(3 \mathrm{x}$ 
$10 \mathrm{~mL}$ ). The undissolved solid was then dried in vacuo, affording 2-homopropargyl-1,3cyclohexanedione (S7) as a white powder (1.06 g, $6.45 \mathrm{mmol}, 100 \%$ yield) which was used without further purification.

Synthesis of (1m): To an 8-mL vial equipped with a stir bar was added 2homopropargyl-1,3-cyclohexanedione (100 mg, $0.61 \mathrm{mmol}, 1.0$ equiv) and $\mathrm{K}_{2} \mathrm{CO}_{3}(101 \mathrm{mg}, 0.73$ mmol, 1.2 equiv). Acetone $(3 \mathrm{~mL})$ was added, and the mixture was stirred for 10 minutes at room temperature. Iodomethane $(114 \mu \mathrm{L}, 1.83 \mathrm{mmol}, 3.0$ equiv) was added, and the reaction was sealed and heated at $60{ }^{\circ} \mathrm{C}$ for $4 \mathrm{~h}$. The reaction was cooled to room temperature, filtered through Celite, and concentrated by rotary evaporation. The product was purified by silica gel chromatography (4:1 hex:EtOAc) affording 2-homopropargyl-2-methyl-1,3-cyclohexanedione (1m) as a clear, colorless oil (75.7 $\mathrm{mg}, 0.425 \mathrm{mmol}, 70 \%$ yield).

Synthesis of (1n): In a $\mathrm{N}_{2}$-filled glovebox, to an 8-mL vial equipped with a stir bar was added $\mathrm{CuCl}$ (16.7 mg, $0.17 \mathrm{mmol}, 7.5 \mathrm{~mol} \%$ ), PPh $(49 \mathrm{mg}, 0.19 \mathrm{~mol}, 8.3 \mathrm{~mol} \%)$, and $\mathrm{KO}$ tBu (19.0 $\mathrm{mg}, 0.17 \mathrm{mmol}, 7.5 \mathrm{~mol} \%)$. THF $(2.5 \mathrm{~mL})$ was added, and the solution for stirred $30 \mathrm{~min}$ at room temperature. $\mathrm{B}_{2}$ (pin)2 (630 mg, $2.48 \mathrm{mmol}, 1.10$ equiv) was added at once as a solid, resulting in an immediate color change to dark brown. After stirring $15 \mathrm{~min}$, the reaction was diluted with THF (2.5 mL), followed by addition of neat 2-homopropargyl-2-methyl-1,3-cyclohexanedione (1m) (402 mg, $2.255 \mathrm{mmol}, 1.0$ equiv). The reaction was sealed and removed from the glovebox, then cooled to $0{ }^{\circ} \mathrm{C}$. Distilled $\mathrm{MeOH}(183 \mu \mathrm{L}, 4.51 \mathrm{mmol}, 2.0$ equiv) was added over the course of $1 \mathrm{~min}$. After $10 \mathrm{~min}$, the reaction was allowed to warm to room temperature and stirred for 18 h.

The reaction was transferred under air to a $50 \mathrm{~mL}$ round bottom flask and quenched with saturated $\mathrm{NH}_{4} \mathrm{Cl}(a q)(20 \mathrm{~mL})$. The mixture was stirred vigorously for $30 \mathrm{~min}$, followed by extraction with EtOAc $(3 \times 20 \mathrm{~mL})$. The combined organic phases were dried over $\mathrm{MgSO}_{4}$, concentrated by rotary evaporation, and analyzed by ${ }^{1} \mathrm{H}$ NMR, which indicated a 2:2:1 ratio of desired product: internal borylation: double hydroboration. Purification by flash silica gel chromatography (6:1 benzene:EtOAc) provided the pure (E)-vinyl boronic ester (1n) as a yellow oil (209 mg, $0.68 \mathrm{mmol}, 30 \%$ yield).

(E)-2-methyl-2-(3-(4,4,5,5-tetramethyl-1,3,2-dioxaborolan-2-yl)allyl)cyclohexane-1,3-dione (2a) 


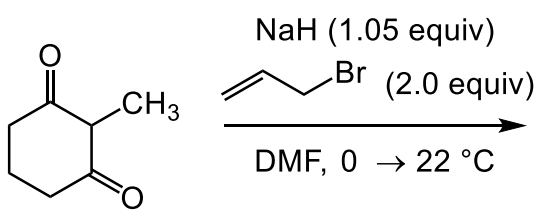

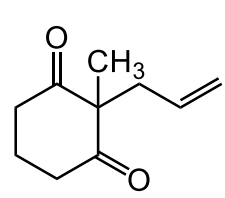

(S8)

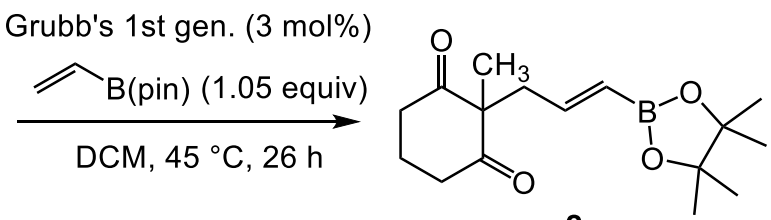

2a

To an oven dried $50 \mathrm{~mL}$ round bottom flask under $\mathrm{N}_{2}$ was added 2-methyl-1,3cyclohexanedione (500 mg, $3.96 \mathrm{mmol}, 1.0$ equiv) and $\mathrm{NaH}$ (60\% dispersion in mineral oil) (166.2 $\mathrm{mg}$ dispersion, $4.16 \mathrm{mmol}, 1.05$ equiv). The round bottom was cooled to $0{ }^{\circ} \mathrm{C}$, and $0{ }^{\circ} \mathrm{C}$ anhydrous DMF $(21 \mathrm{~mL})$ was added to the reaction. After $30 \mathrm{~min}$ of stirring at $0{ }^{\circ} \mathrm{C}$, the reaction was allowed to warm to $22{ }^{\circ} \mathrm{C}$ and stirred $5 \mathrm{~min}$. The reaction was then cooled to $0{ }^{\circ} \mathrm{C}$, followed by addition of allyl bromide $\left(685 \mu \mathrm{L}, 7.93 \mathrm{mmol}, 2.0\right.$ equiv). After $3 \mathrm{~h}$ at $0{ }^{\circ} \mathrm{C}$, the reaction was stirred for $48 \mathrm{~h}$ at $22{ }^{\circ} \mathrm{C}$. The reaction was diluted with EtOAc $(50 \mathrm{~mL})$, and the organic layer was extracted with saturated $\mathrm{NH}_{4} \mathrm{Cl}(a q)(3 \times 25 \mathrm{~mL})$, saturated $\mathrm{LiCl}(3 \times 20 \mathrm{~mL})$, water $(1 \times 25$ $\mathrm{mL})$, and brine $(1 \times 25 \mathrm{~mL})$. The organic layer was dried with $\mathrm{MgSO}_{4}$, filtered, and concentrated by rotary evaporation. Purification by silica gel chromatography (3:1 hex:EtOAc) afforded dione (S8) as a clear, colorless oil (371 mg, $2.23 \mathrm{mmol}$, 57\% yield). NMR characterization was consistent with the literature. ${ }^{13}$

To an oven-dried $25 \mathrm{~mL}$ round bottom flask with a stir bar under $\mathrm{N}_{2}$ was added Grubb's $1^{\text {st }}$ generation catalyst $(55.2 \mathrm{mg}, 0.067 \mathrm{mmol}, 3 \mathrm{~mol} \%$ ). The flask was equipped with a reflux condenser. The catalyst was dissolved in dry DCM (10 mL), and 2-allyl-2-methyl-1,3cyclohexanedione (S8) (371 mg, $2.23 \mathrm{mmol}, 1.0$ equiv) was added neat. Immediately, vinyl boronic acid pinacol ester $(398 \mu \mathrm{L}, 2.35 \mathrm{mmol}, 1.05$ equiv) was added neat by syringe. The reaction was heated to $45^{\circ} \mathrm{C}$ for $26 \mathrm{~h}$, at which point the reaction was concentrated by rotary evaporation. The product was purified by silica gel chromatography (5:1 $\rightarrow$ 1:1 hex:EtOAc) giving a dark oil. The oil was dissolved in DCM $(238 \mu \mathrm{L})$ and DMSO $(238 \mu \mathrm{L})$ and stirred for 22 $\mathrm{h}$. The solution was diluted with water $(1 \mathrm{~mL})$ and extracted $5 \times 1 \mathrm{~mL}$ EtOAc. The combined organic phases were dried over $\mathrm{MgSO}_{4}$, filtered, concentrated by rotary evaporation, and the residue purified by silica gel chromatography (5:1 $\rightarrow$ 1:1 hex:EtOAc), giving a light green oil, which solidified to a white solid upon azeotropic distillation with benzene.

1H NMR: (400 MHz, $\left.\mathrm{CDCl}_{3}\right)$ : 6.35-6.27 (dt, $\left.17.6 \mathrm{~Hz}, 7.1 \mathrm{~Hz}, 1 \mathrm{H}\right) ; 5.44-5.39$ (d, $\left.17.8 \mathrm{~Hz}, 1 \mathrm{H}\right)$; 2.72$2.57(\mathrm{~m}, 6 \mathrm{H}) ; 2.05-1.96(\mathrm{~m}, 1 \mathrm{H}) ; 1.91-1.80(\mathrm{~m}, 1 \mathrm{H}) ; 1.24$ (s, 3H); 1.22 (s, 12H). ${ }^{13} \mathrm{C}$ NMR: $(214 \mathrm{MHz}$, $\left.\mathrm{CDCl}_{3}\right)$ : 209.5, 146.8, 123.8, 83.3, 65.3, 43.2, 38.1, 24.9, 19.6, 17.7. HRMS (m/z): calcd for $\mathrm{C}_{16} \mathrm{H}_{26} \mathrm{BO}_{4}^{+}: 293.1919\left(\mathrm{M}+\mathrm{H}^{+}\right)$; found: 293.1907. IR $\left(\mathrm{v} / \mathrm{cm}^{-1}\right)$ : $2977.6(\mathrm{~m}), 2935.1(\mathrm{w}), 1726.9(\mathrm{~m})$, $1697.0(\mathrm{~s}), 1637.3(\mathrm{~m}), 1392.4(\mathrm{w}), 1361.5(\mathrm{~s}), 1323.9(\mathrm{~m}), 1144.5(\mathrm{~m}), 971.0(\mathrm{w}), 848.5(\mathrm{w})$.

\section{(E)-2-methyl-2-(3-(4,4,5,5-tetramethyl-1,3,2-dioxaborolan-2-yl)allyl)cyclopentane-1,3-dione} (2g) 

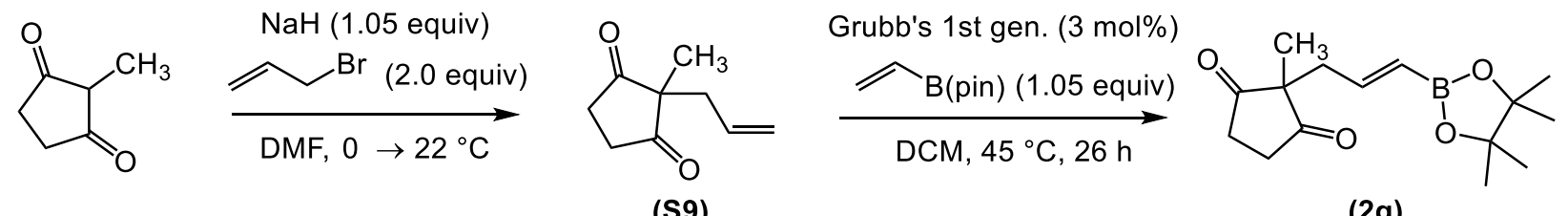

(S9)

(2g)

(S9) and (2g) were prepared according to the above procedure followed for (S21) and (2a).

Characterization of (2g): ${ }^{1} \mathbf{H}$ NMR: $\left(400 \mathrm{MHz}, \mathrm{CDCl}_{3}\right)$ : $6.31-6.23$ (dt, $\left.17.8 \mathrm{~Hz}, 7.1 \mathrm{~Hz}, 1 \mathrm{H}\right)$; $5.37-$ $5.33(\mathrm{~d}, 17.8 \mathrm{~Hz}, 1 \mathrm{H}) ; 2.75-2.60$ (m, 4H); 2.39-2.37 (dd, 7.1 Hz, $1.2 \mathrm{~Hz}, 2 \mathrm{H}) ; 1.17$ (s, 12H); 1.06 (s, 3H). ${ }^{13} \mathrm{C}$ NMR: $\left(214 \mathrm{MHz}, \mathrm{CDCl}_{3}\right): 215.7,145.8,124.3,83.2,56.5,41.8,35.3,24.7,18.9$. HRMS $(\mathrm{m} / \mathrm{z})$ : calcd for $\mathrm{C}_{15} \mathrm{H}_{24} \mathrm{BO}_{4}^{+}: 279.1762\left(\mathrm{M}+\mathrm{H}^{+}\right)$; found: 279.1753. IR $\left(\mathrm{v} / \mathrm{cm}^{-1}\right): 2978.5(\mathrm{~s}), 2931.3(\mathrm{~m})$, $1725.0(\mathrm{~s}), 1638.2(\mathrm{~m}), 1361.5(\mathrm{~s}), 1327.8(\mathrm{~s}), 1145.5(\mathrm{~s}), 971.0(\mathrm{~m}), 848.5(\mathrm{~m})$.

(E)-3-methyl-3-(3-(4,4,5,5-tetramethyl-1,3,2-dioxaborolan-2-yl)allyl)pentane-2,4-dione (2j)

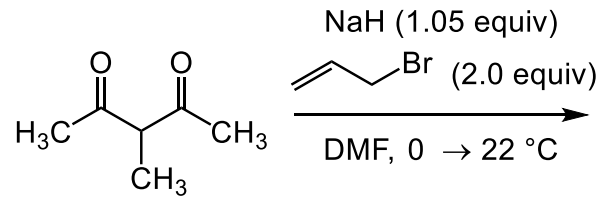

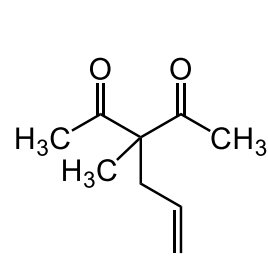

(S10)
Grubb's 1st gen. (3 mol\%)

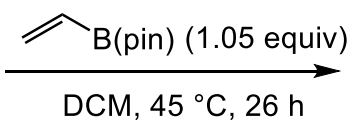<smiles>CC(=O)C(C)(CC=CB1OC(C)(C)C(C)(C)O1)C(C)=O</smiles>

(2j)

(S10) and (2j) were prepared according to the above procedure for (S21) and (2a).

Characterization of (2j): ${ }^{1} \mathrm{H}$ NMR (400 MHz, $\left.\mathrm{CDCl}_{3}\right)$ : 6.33-6.25 (dt, 17.8 Hz, 7.1 Hz, 1H); 5.48-5.44 $(\mathrm{d}, 17.8 \mathrm{~Hz}, 1 \mathrm{H}) ; 2.67-2.64(\mathrm{dd}, 7.3 \mathrm{~Hz}, 1.2 \mathrm{~Hz}, 2 \mathrm{H}) ; 2.06(\mathrm{~s}, 6 \mathrm{H}) ; 1.28(\mathrm{~s}, 3 \mathrm{H}) ; 1.20(\mathrm{~s}, 12 \mathrm{H}) .{ }^{13} \mathrm{C}$ NMR: (214 MHz, $\left.\mathrm{CDCl}_{3}\right)$ : 206.3, 147.1, 128.3, 83.2, 66.3, 40.8, 26.5, 24.7, 18.1. HRMS (m/z): calcd for $\mathrm{C}_{15} \mathrm{H}_{26} \mathrm{BO}_{4}^{+}$: $281.1919\left(\mathrm{M}+\mathrm{H}^{+}\right)$; found: 281.1909. IR $\left(\mathrm{v} / \mathrm{cm}^{-1}\right)$ : $2979.5(\mathrm{~s}), 2934.2(\mathrm{w}), 1718.2(\mathrm{~m})$, $1699.4(\mathrm{~s}), 1638.2(\mathrm{~m}), 1361.5(\mathrm{~s}), 1327.7$ (m), $1145.5(\mathrm{~s}), 971.0(\mathrm{~m}), 848.5(\mathrm{~m})$. 


\section{- Product Functionalizations}

\section{A. Oxidation}
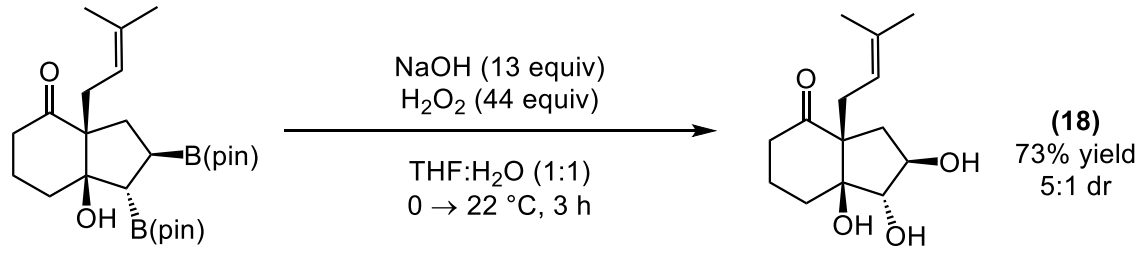

(3c), 5:1 dr

To an $8 \mathrm{~mL}$ vial with stir bar was added bis-boronate (3c) $(21.6 \mathrm{mg}, 0.0455 \mathrm{mmol}, 1.0$ equiv) and $500 \mu \mathrm{L}$ THF. The solution was cooled to $0{ }^{\circ} \mathrm{C}$. Solutions of $2 \mathrm{M} \mathrm{NaOH}(a q)$ and $\mathrm{H}_{2} \mathrm{O}_{2}$ (aq) $(30 \mathrm{wt} \%)$ were cooled to $0{ }^{\circ} \mathrm{C}$. The $\mathrm{NaOH}$ solution $(300 \mu \mathrm{L})$ was added to the reaction, followed immediately by $\mathrm{H}_{2} \mathrm{O}_{2}(204 \mu \mathrm{L})$. The reaction was stirred 30 minutes at $0{ }^{\circ} \mathrm{C}$, then allowed to warm to room temperature and stirred an additional 3 hours. EtOAc ( $2 \mathrm{~mL}$ ), saturated aqueous $\mathrm{NH}_{4} \mathrm{Cl}(1 \mathrm{~mL})$, and solid $\mathrm{NaCl}(\sim 200 \mathrm{mg})$ were then added. The aqueous layer was extracted with EtOAc $(3 \times 2 \mathrm{~mL})$, and the organic layers were combined, dried with $\mathrm{MgSO}_{4}$, and concentrated by rotary evaporation. Column chromatography (1:2 hex:EtOAc) afforded triol (18) $\left(8.8 \mathrm{mg}, 0.033 \mathrm{mmol}, 73 \%\right.$ yield, 5:1 dr). Minor impurities in the ${ }^{1} \mathrm{H}$ NMR spectrum between 4.10-4.45 ppm could not be removed by column chromatography.

${ }^{1}$ H NMR (500 MHz, CD 3 OD): 3.79-3.78 (d, 4.3 Hz, 1H); 3.74-3.70 (m, 1H); 2.87-2.83 (dd, 13.4 Hz, $7.3 \mathrm{~Hz}, 1 \mathrm{H}) ; 2.55-2.47(\mathrm{~m}, 3 \mathrm{H}) ; 2.22-2.14(\mathrm{~m}, 1 \mathrm{H}) ; 2.08-1.83(\mathrm{~m}, 6 \mathrm{H}) ; 1.68(\mathrm{~d}, 0.9 \mathrm{~Hz}, 3 \mathrm{H}) ; 1.64(\mathrm{~s}$, $3 \mathrm{H}) ; 1.43-1.39$ (dd, $13.4 \mathrm{~Hz}, 6.1 \mathrm{~Hz}, 1 \mathrm{H}) .{ }^{13} \mathrm{C}\left(214 \mathrm{MHz}, \mathrm{CD}_{3} \mathrm{OD}\right): 215.8,134.6,120.9,87.9,85.2$, 77.0, 62.6, 38.0, 37.8, 34.0, 31.8, 26.1, 21.0, 18.0. HRMS (m/z): calcd for $\mathrm{C}_{14} \mathrm{H}_{23} \mathrm{O}_{4}{ }^{+}: 255.1591\left(\mathrm{M}^{+} \mathrm{H}^{+}\right)$;

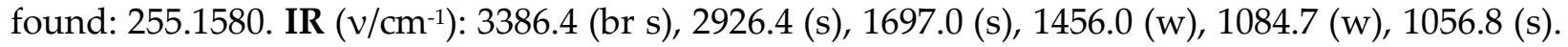
$[\alpha]_{\mathrm{D}^{23}}=-24.9^{\circ}\left(\mathrm{c}=0.44, \mathrm{CH}_{2} \mathrm{Cl}_{2}, 1=1 \mathrm{dm}\right)$.

\section{B. Dehydration (Example 1)}

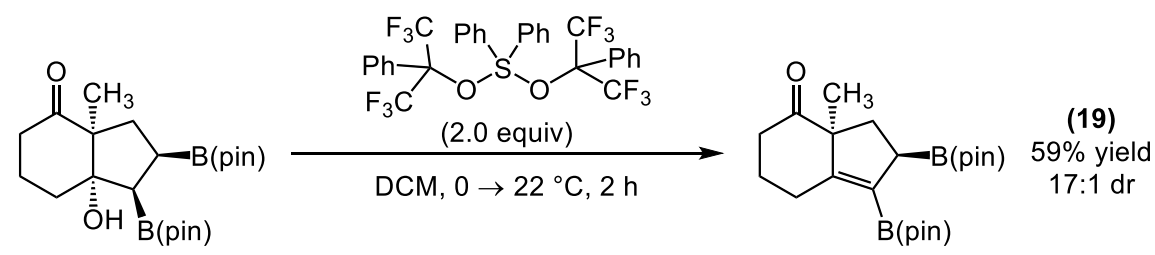

(3a), 13:1 dr

To an $8 \mathrm{~mL}$ vial with stir bar was added bis-boronate (3a) (12.3 mg, 13:1 dr, $0.0293 \mathrm{mmol}$, 1.0 equiv). The vial was evacuated, and backfilled with $\mathrm{N}_{2}$, followed by addition of dry DCM (50 $\mu \mathrm{L}$ ). In a $\mathrm{N}_{2}$ filled glovebox, Martin's sulfurane $(39.4 \mathrm{mg}, 0.0586 \mathrm{mmol}, 2.0$ equiv) was dissolved in $100 \mu \mathrm{L}$ DCM. This vial was sealed with a Teflon-lined septa cap, tapped with electrical tape, and removed from the glovebox. Both solutions were cooled to $0{ }^{\circ} \mathrm{C}$, and the sulfurane added dropwise to the bis-boronate. The sulfurane vial was washed with an 
additional $50 \mu \mathrm{L}$ DCM, which was added to the reaction dropwise. The reaction turned yellow within $2 \mathrm{~min}$, and the reaction was allowed to warm to room temperature after $5 \mathrm{~min}$. After stirring $2 \mathrm{~h}$, the reaction was concentrated by rotary evaporation. Purification by silica gel chromatography (15:1 hex:EtOAc $\rightarrow$ 10:1 hex:EtOAc) afforded vinyl boronic ester (19) as a clear, colorless oil (6.9 mg, $0.0172 \mathrm{mmol}, 59 \%$ yield, 17:1 dr).

${ }^{1} \mathbf{H}$ NMR (600 MHz, $\left.\mathrm{CDCl}_{3}\right)$ : 3.19-3.16 (app d, $\left.14.6 \mathrm{~Hz}, 1 \mathrm{H}\right)$; 2.62-2.55 (app td, $14.3 \mathrm{~Hz}, 6.1 \mathrm{~Hz}$, $1 \mathrm{H})$; 2.34-2.22 (m, 2H); 2.20-2.13 (m, 1H); 2.12-1.97 (m, 2H); 1.85-1.80 (dd, $12.8 \mathrm{~Hz}, 7.3 \mathrm{~Hz}, 1 \mathrm{H})$, 1.25 (s, 6H); 1.24 (s, 6H); 1.23 (s, 12H); 1.20 (s, 3H). ${ }^{13} \mathrm{C}\left(151 \mathrm{MHz}, \mathrm{CDCl}_{3}\right): 214.8,161.8,124.9,83.1$, 64.0, 38.3, 35.6, 25.2, 25.1, 24.9, 24.7, 24.4, 22.6. HRMS $(\mathrm{m} / \mathrm{z})$ : calcd for $\mathrm{C}_{22} \mathrm{H}_{36} \mathrm{~B}_{2} \mathrm{O}_{5} \mathrm{Na}^{+}: 425.2641$ $\left(\mathrm{M}+\mathrm{Na}^{+}\right)$; found: 425.2643. IR $\left(\mathrm{v} / \mathrm{cm}^{-1}\right)$ : $2976.6(\mathrm{w}), 2929.3(\mathrm{w}), 2359.5(\mathrm{~m}), 2341.2(\mathrm{~m}), 1716.3(\mathrm{~m})$, $1698.0(\mathrm{~m}), 1456.9(\mathrm{~m}), 1145.5(\mathrm{w}), 981.6(\mathrm{w}), 851.4(\mathrm{w}), 669.2(\mathrm{w}) .[\alpha]_{\mathrm{D}^{23}}=+18.1{ }^{\circ}(\mathrm{c}=0.34$, $\left.\mathrm{CH}_{2} \mathrm{Cl}_{2}, \mathrm{l}=1 \mathrm{dm}\right)$.

\section{Dehydration (Example 2)}

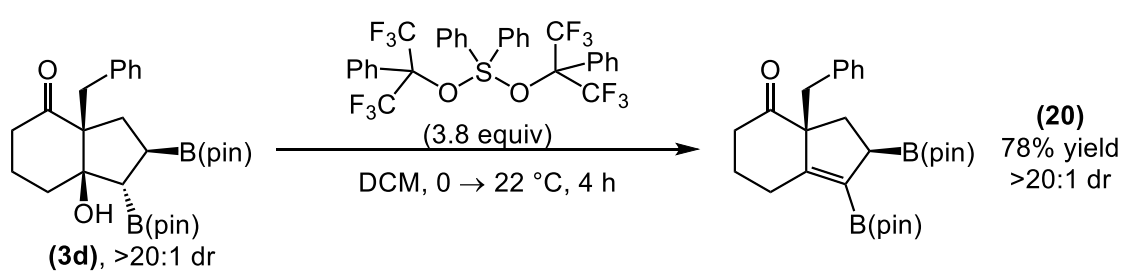

To an $8 \mathrm{~mL}$ vial with stir bar was added bis-boronate (3d) $(10.8 \mathrm{mg},>20: 1 \mathrm{dr}, 0.0218$ mmol, 1.0 equiv). The vial was evacuated, and backfilled with $\mathrm{N}_{2}$, followed by addition of dry DCM $(150 \mu \mathrm{L})$. In a $\mathrm{N}_{2}$ filled glovebox, Martin's sulfurane $(56.0 \mathrm{mg}, 0.0832 \mathrm{mmol}, 3.8$ equiv) was dissolved in $200 \mu \mathrm{L}$ DCM. This vial was sealed with a Teflon-lined septa cap, tapped with electrical tape, and removed from the glovebox. Both solutions were cooled to $0{ }^{\circ} \mathrm{C}$, and the sulfurane added dropwise to the bis-boronate. The sulfurane vial was washed with an additional $50 \mu \mathrm{L}$ DCM, which was added to the reaction dropwise. The reaction turned yellow within $2 \mathrm{~min}$, and the reaction was allowed to warm to room temperature after $5 \mathrm{~min}$. After stirring $4 \mathrm{~h}$, the reaction was concentrated by rotary evaporation. Purification by silica gel chromatography (25:1 hex:EtOAc $\rightarrow$ 10:1 hex:EtOAc) afforded vinyl boronic ester (20) as a clear, colorless oil ( $8.1 \mathrm{mg}, 0.0169 \mathrm{mmol}, 78 \%$ yield, >20:1 dr). A small amount of aromatic impurities co-elute with the product and could not be removed by column chromatography.

${ }^{1}$ H NMR (600 MHz, $\left.\mathrm{CDCl}_{3}\right)$ : 7.24-7.21 (m, 2H); 7.19-7.17 (m, 1H); 7.14-7.13 (app d, 7.3 Hz, 2H); 3.30-3.28 (d, $13.9 \mathrm{~Hz}, 1 \mathrm{H})$; 3.17-3.15 (d, $14.3 \mathrm{~Hz}, 1 \mathrm{H}) ; 2.84-2.78(\mathrm{~m}, 2 \mathrm{H}) ; 2.46-2.41$ (m, 2H); 2.31$2.25(\mathrm{~m}, 2 \mathrm{H}) ; 2.12-2.06(\mathrm{~m}, 1 \mathrm{H}) ; 1.98-1.94(\mathrm{~m}, 1 \mathrm{H}) ; 1.57-1.48(\mathrm{~m}, 1 \mathrm{H}) ; 1.28(\mathrm{~s}, 6 \mathrm{H}) ; 1.27(\mathrm{~s}, 6 \mathrm{H}) ; 1.27$ (s, 6H); $1.26(\mathrm{~s}, 6 \mathrm{H}) .{ }^{13} \mathrm{C}\left(151 \mathrm{MHz}, \mathrm{CDCl}_{3}\right): 212.4,158.5,137.9,129.8,128.2,126.7,124.9,83.4,83.2$, 70.6, 42.8, 39.7, 30.2, 26.1, 25.8, 25.3, 25.0, 24.6. HRMS $(\mathrm{m} / \mathrm{z})$ : calcd for $\mathrm{C}_{28} \mathrm{H}_{41} \mathrm{~B}_{2} \mathrm{O}_{5}{ }^{+}: 479.3135$ 


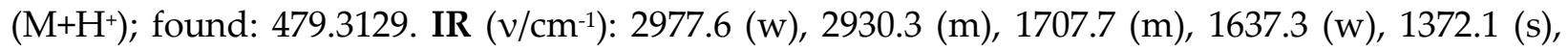
$1313.3(\mathrm{~m}) ; 1144.6(\mathrm{~s}), 967.1(\mathrm{w}), 858.2(\mathrm{w}), 701.0(\mathrm{w}) .[\alpha]_{\mathrm{D}^{23}}=+72.6^{\circ}\left(\mathrm{c}=0.34, \mathrm{CH}_{2} \mathrm{Cl}_{2}, 1=1 \mathrm{dm}\right)$.

C. Anti Boron-Hydroxyl Elimination (example 1)
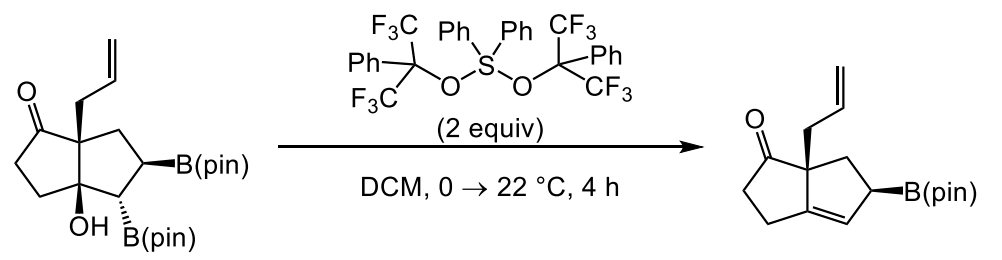

(21)

$57 \%$ yield

(5b), $>20: 1 \mathrm{dr}$

To an $8 \mathrm{~mL}$ vial with stir bar was added bis-boronate $\mathbf{( 5 b )}(24.7 \mathrm{mg},>20: 1 \mathrm{dr}, 0.0572$ mmol, 1.0 equiv). Dry DCM $(100 \mu \mathrm{L})$ was added. In a $\mathrm{N}_{2}$ filled glovebox, Martin's sulfurane (76.9 mg, $0.114 \mathrm{mmol}, 2.0$ equiv) was dissolved in $150 \mu \mathrm{L}$ DCM. This vial was sealed with a Teflon-lined septa cap, tapped with electrical tape, and removed from the glovebox. Both solutions were cooled to $0{ }^{\circ} \mathrm{C}$, and the sulfurane added dropwise to the bis-boronate. The sulfurane vial was washed with an additional $50 \mu \mathrm{L}$ DCM, which was added to the reaction dropwise. The reaction turned yellow within $2 \mathrm{~min}$, and the reaction was allowed to warm to room temperature after $5 \mathrm{~min}$. After stirring $4 \mathrm{~h}$, the reaction had turned red and was concentrated by rotary evaporation. Purification by silica gel chromatography (20:1 hex:EtOAc $\rightarrow 10: 1$ hex:EtOAc) afforded allyl boronic ester (21) as a clear, colorless oil (9.4 mg, $0.0326 \mathrm{mmol}$, $57 \%$ yield, $>20: 1 \mathrm{dr})$.

${ }^{1} \mathbf{H}$ NMR (500 MHz, $\left.\mathrm{CDCl}_{3}\right)$ : 5.82-5.74 (m, 1H); 5.56 (t, $\left.2.3 \mathrm{~Hz}, 1 \mathrm{H}\right) ;$ 5.12-5.06 (m, 2H); 2.69-2.63 $(\mathrm{m}, 1 \mathrm{H}) ; 2.61-2.50(\mathrm{~m}, 2 \mathrm{H}) ; 2.45-2.40(\mathrm{dd}, 18.0 \mathrm{~Hz}, 8.8 \mathrm{~Hz}, 1 \mathrm{H}) ; 2.38-2.32(\mathrm{~m}, 2 \mathrm{H}) ; 2.29-2.24(\mathrm{dd}$, 13.7 Hz, 7.9 Hz, 1H); 2.13-2.03 (m, 2H); 1.25 (s, 12H). ${ }^{13} \mathrm{C}\left(151 \mathrm{MHz}, \mathrm{CDCl}_{3}\right):$ 218.2, 146.6, 133.8, 124.6, 118.3, 83.6, 65.4, 40.7, 39.2, 32.3, 25.0, 24.8, 22.2. HRMS (m/z): calcd for $\mathrm{C}_{17} \mathrm{H}_{26} \mathrm{BO}_{3}{ }^{+}$: 289.1970 $\left(\mathrm{M}+\mathrm{H}^{+}\right)$; found: 289.1970. IR $\left(\mathrm{v} / \mathrm{cm}^{-1}\right)$ : $2977.6(\mathrm{~m}), 2359.4(\mathrm{w}), 1737.6(\mathrm{~s}), 1354.8(\mathrm{~s})$, $1320.0(\mathrm{~s}), 1143.5(\mathrm{~s}), 857.2(\mathrm{~m}) .[\alpha]_{\mathrm{D}^{23}}=-19.4^{\circ}\left(\mathrm{c}=0.47, \mathrm{CH}_{2} \mathrm{Cl}_{2}, 1=1 \mathrm{dm}\right)$.

Anti Boron-Hydroxyl Elimination (example 2)

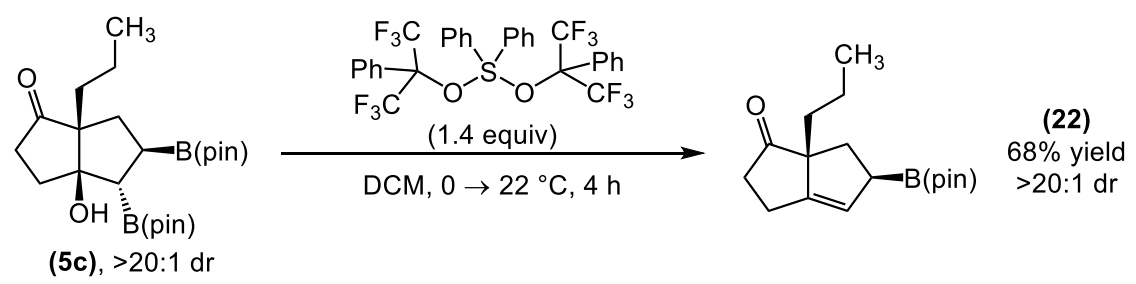

To an $8 \mathrm{~mL}$ vial with stir bar was added bis-boronate $(5 \mathrm{c})(160 \mathrm{mg},>20: 1 \mathrm{dr}, 0.368 \mathrm{mmol}, 1.0$ equiv). Dry DCM (700 $\mu \mathrm{L})$ was added. In a N2 filled glovebox, Martin's sulfurane (348 mg, 0.518 mmol, 1.41 equiv) was dissolved in $700 \mu \mathrm{L}$ DCM. This vial was sealed with a Teflon-lined septa 
cap, tapped with electrical tape, and removed from the glovebox. Both solutions were cooled to $0{ }^{\circ} \mathrm{C}$, and the sulfurane added dropwise to the bis-boronate. The sulfurane vial was washed with an additional $325 \mu \mathrm{L}$ DCM, which was added to the reaction dropwise. The reaction turned yellow within $2 \mathrm{~min}$, and the reaction was allowed to warm to room temperature after 5 min. After stirring $4 \mathrm{~h}$, the reaction had turned red and was concentrated by rotary evaporation. Purification by silica gel chromatography (25:1 hex:EtOAc) afforded allyl boronic ester (22) as a clear, colorless oil (72.6 mg, $0.250 \mathrm{mmol}, 68 \%$ yield, >20:1 dr).

${ }^{1} \mathrm{H}$ NMR (600 MHz, CDCl$)$ ) 5.54-5.53 (app t, $\left.2.6 \mathrm{~Hz}, 1 \mathrm{H}\right)$; 2.70-2.64 (ddd, $18.7 \mathrm{~Hz}, 9.5 \mathrm{~Hz}, 2.6 \mathrm{~Hz}$, $1 \mathrm{H})$; 2.59-2.49 (m, 2H); 2.42-2.33 (m, 2H); 2.15-2.11 (dd, $13.2 \mathrm{~Hz}, 11.0 \mathrm{~Hz}, 1 \mathrm{H}) ; 2.03-2.01$ (dd, 12.8 $\mathrm{Hz}, 1.5 \mathrm{~Hz}, 1 \mathrm{H}) ; 1.53-1.42(\mathrm{~m}, 2 \mathrm{H}) ; 1.36-1.30(\mathrm{~m}, 2 \mathrm{H}) ; 1.24(\mathrm{~s}, 6 \mathrm{H}) ; 1.24(\mathrm{~s}, 6 \mathrm{H}) ; 0.89-0.87(\mathrm{t}, 3 \mathrm{H})$. ${ }^{13} \mathrm{C}\left(151 \mathrm{MHz}, \mathrm{CDCl}_{3}\right):$ 218.7, 146.9, 123.8, 83.6, 65.6, 40.6, 36.6, 32.2, 25.0, 24.8, 22.1, 18.0, 14.6. HRMS ( $\mathrm{m} / \mathrm{z})$ : calcd for $\mathrm{C}_{17} \mathrm{H}_{28} \mathrm{BO}_{3}{ }^{+}: 291.2126\left(\mathrm{M}+\mathrm{H}^{+}\right)$; found: 291.2114 . IR $\left(\mathrm{v} / \mathrm{cm}^{-1}\right)$ : $2975.6(\mathrm{~m})$, $2930.3(\mathrm{~m}), 2872.2(\mathrm{w}), 1735.6(\mathrm{~s}), 1354.8(\mathrm{~s}), 1318.1(\mathrm{~m}), 1214.9(\mathrm{w}), 1143.6(\mathrm{~s}), 860.1(\mathrm{~m}), 681.7$ $(\mathrm{w}) \cdot[\alpha]_{\mathrm{D}}^{23}=-5.5^{\circ}\left(\mathrm{c}=0.38, \mathrm{CH}_{2} \mathrm{Cl}_{2}, \mathrm{l}=1 \mathrm{dm}\right)$.

\section{E. Allylation}

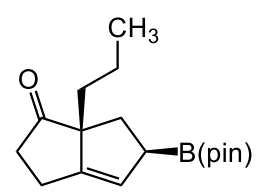

(22), $>20: 1 d r$

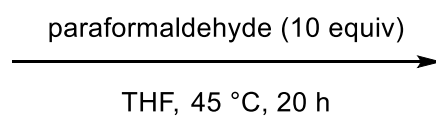

THF, $45^{\circ} \mathrm{C}, 20 \mathrm{~h}$

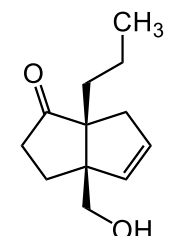

(23)

$73 \%$ yield, $18: 1 \mathrm{dr}$

To an $8 \mathrm{~mL}$ vial with stir bar was added allyl boronic ester (22) $(14.5 \mathrm{mg},>20: 1 \mathrm{dr}, 0.050$ mmol, 1.0 equiv) and $250 \mu \mathrm{L}$ dry THF. Paraformaldehyde $(15.0 \mathrm{mg}, 0.50 \mathrm{mmol}, 10$ equiv) was added as a solid. The vial was capped, sealed with electrical tape, and heated at $45^{\circ} \mathrm{C}$ for $20 \mathrm{~h}$. The reaction was cooled to room temperature, diluted with EtOAc $(1 \mathrm{~mL})$, and filtered through a short pad of Celite. The vial was washed with EtOAc $(3 \times 1 \mathrm{~mL})$, and suspensions filtered through Celite. The solvent was removed by rotary evaporation, and the residue purified by silica gel chromatography (4:1 hex:EtOAc) to give primary alcohol (23) as a clear, colorless oil (7.1 mg, 18:1 dr, 73\% yield).

${ }^{1}$ H NMR (600 MHz, $\mathrm{CDCl}_{3}$ ): 5.98-5.95 (br s, 1H); 5.48-5.45 (m, 1H); 3.74-3.72 (d, $\left.11.0 \mathrm{~Hz}, 1 \mathrm{H}\right)$; 3.65-3.63 (d, $11.4 \mathrm{~Hz}, 1 \mathrm{H}) ; 2.70-2.67$ (d, $16.1 \mathrm{~Hz}, 1 \mathrm{H}) ; 2.41-2.36(\mathrm{dd}, 19.4 \mathrm{~Hz}, 9.9 \mathrm{~Hz}, 1 \mathrm{H})$; 2.30-2.26 $(\mathrm{dd}, 16.5 \mathrm{~Hz}, 1.5 \mathrm{~Hz}, 1 \mathrm{H}) ; 2.19-2.12(\mathrm{~m}, 1 \mathrm{H}) ; 1.97-1.93(\mathrm{dd}, 12.8 \mathrm{~Hz}, 9.9 \mathrm{~Hz}, 1 \mathrm{H}) ; 1.74-1.68(\mathrm{~m}, 1 \mathrm{H})$; $1.66-1.61(\mathrm{td}, 13.2 \mathrm{~Hz}, 4.4 \mathrm{~Hz}, 1 \mathrm{H}) ; 1.54-1.49(\mathrm{td}, 12.8 \mathrm{~Hz}, 4.4 \mathrm{~Hz}, 1 \mathrm{H}) ; 1.47-1.39(\mathrm{~m}, 1 \mathrm{H}) ; 1.25(\mathrm{~m}$, 2H); 0.89-0.86 (t, $7.3 \mathrm{~Hz}) .{ }^{13} \mathrm{C}\left(151 \mathrm{MHz}, \mathrm{CDCl}_{3}\right):$ 224.7, 135.3, 134.9, 65.8, 61.5, 60.1, 43.4, 36.5, 
32.9, 26.4, 18.6, 14.9. HRMS (m/z): calcd for $\mathrm{C}_{12} \mathrm{H}_{19} \mathrm{O}_{2}{ }^{+}$: $195.1380(\mathrm{M}+\mathrm{H})$; found: 195.1373. IR $\left(\mathrm{v} / \mathrm{cm}^{-1}\right): 2930.3(\mathrm{w}), 2310.3(\mathrm{w}), 1748.2(\mathrm{~s}), 1732.7(\mathrm{~s}), 1568.8(\mathrm{~s}), 1558.2(\mathrm{~s}), 1540.8(\mathrm{~s}), 1456.96(\mathrm{~m})$, $723.2(\mathrm{w}) .[\alpha]_{\mathrm{D}^{23}}=-112.2^{\circ}\left(\mathrm{c}=0.36, \mathrm{CH}_{2} \mathrm{Cl}_{2}, \mathrm{l}=1 \mathrm{dm}\right)$.

\section{- Product characterization}

(1R,2R,3aS,7aS)-7a-hydroxy-3a-methyl-1,2-bis(4,4,5,5-tetramethyl-1,3,2-dioxaborolan-2yl)octahydro-4H-inden-4-one (3a)

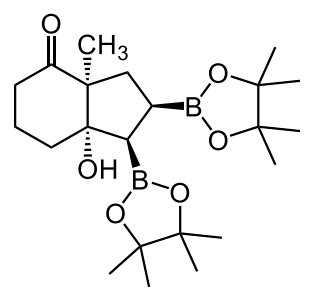

(3a)

This reaction was run using (R)-furyl-OMe-biphep. Silica gel chromatography (100\% DCM $\rightarrow$ 98.5:1.5 DCM:i-PrOH) provided (3a) as a clear, colorless oil (29.3 mg, 70\% yield, 13:1 dr, >99:1 er).

${ }^{1}$ H NMR (600 MHz, CDCl $): 2.58$ (dt, $\left.15.0 \mathrm{~Hz}, 6.2 \mathrm{~Hz}, 1 \mathrm{H}\right) ; 2.28$ (d, $\left.15.0 \mathrm{~Hz}, 1 \mathrm{H}\right) ; 2.19$ (dt, $14.3 \mathrm{~Hz}$, $3.7 \mathrm{~Hz}, 1 \mathrm{H}) ; 2.06$ (dd, $12.8 \mathrm{~Hz}, 8.8 \mathrm{~Hz}, 2 \mathrm{H}) ; 1.97$ (m, 2H); 1.85 (m, 3H); 1.61 (dd, $13.2 \mathrm{~Hz}, 10.3 \mathrm{~Hz}$, 1H); 1.26 (br s, 24H); 1.18 (s, 3H). ${ }^{13} \mathrm{C}$ NMR (151 MHz, $\left.\mathrm{CDCl}_{3}\right)$ : 214.9, 87.47, 83.54, 83.3, 59.2, 38.6, 37.4, 32.5, 25.2, 25.1, 24.6, 21.6, 15.9. HRMS ( $\mathrm{m} / \mathrm{z})$ : calcd for $\mathrm{C}_{22} \mathrm{H}_{37} \mathrm{~B}_{2} \mathrm{O}_{6}: 419.2782\left(\mathrm{M}-\mathrm{H}^{+}\right)$; found: 419.2795. IR (v/cm-1): $2978(\mathrm{~s}), 2939(\mathrm{~m}), 2360(\mathrm{w}), 1698(\mathrm{~s}), 1685(\mathrm{~m}), 1541(\mathrm{~m}), 1507(\mathrm{w}), 1457$ (w), $1373(\mathrm{~s}), 1319(\mathrm{~m}), 1146(\mathrm{~s}), 967(\mathrm{w}), 854(\mathrm{w}) .[\alpha]_{\mathrm{D}^{23}}=+10.2^{\circ}\left(\mathrm{c}=1.44, \mathrm{CH}_{2} \mathrm{Cl}_{2}, \mathrm{l}=1 \mathrm{dm}\right)$.

Diacel CHIRALPAK IC Column: 85:15 hexanes:iPrOH; $1.0 \mathrm{~mL} / \mathrm{min} ; 205 \mathrm{~nm}$.

\section{Racemic material:}

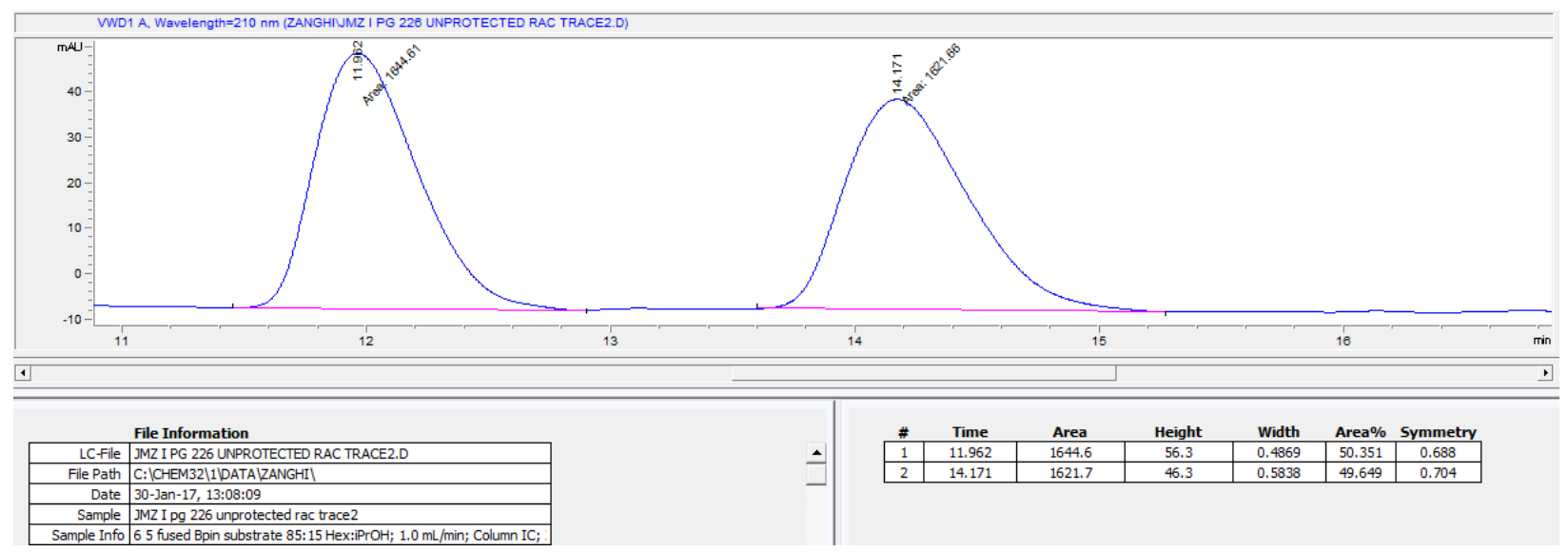


Enantioenriched material:

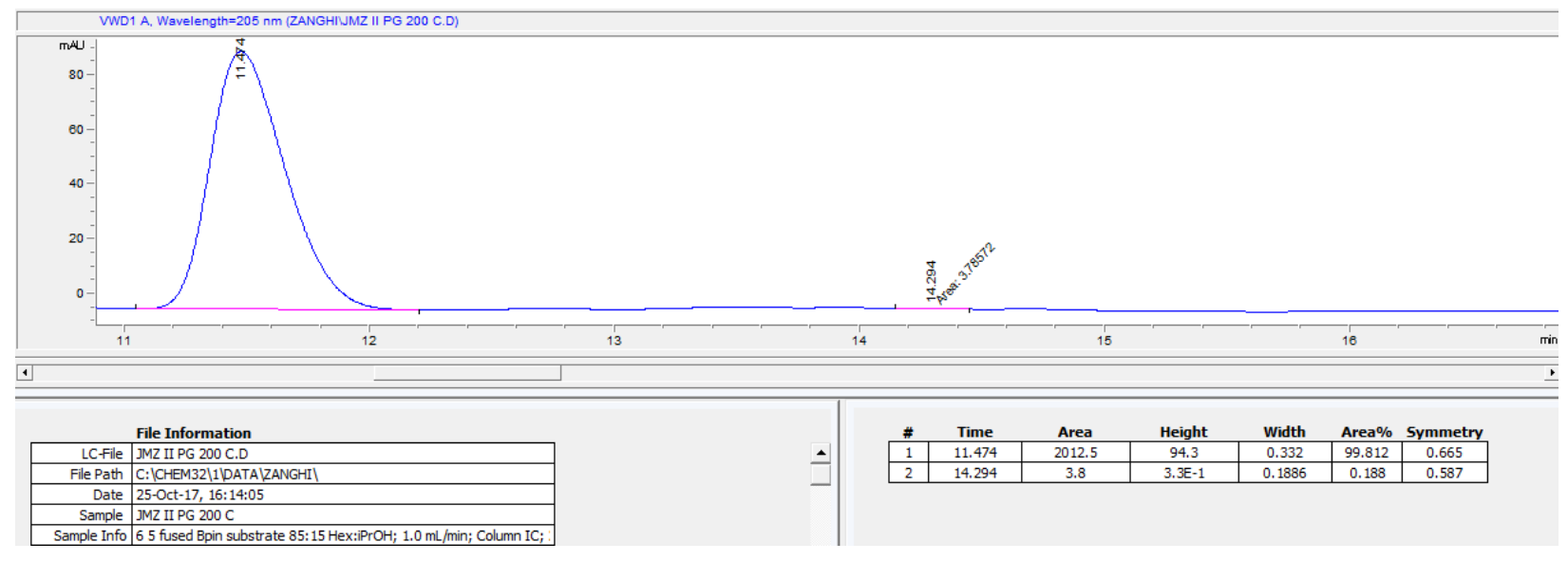

(1R,2S,3aS,7aS)-7a-hydroxy-3a-methyl-1,2-bis(4,4,5,5-tetramethyl-1,3,2-dioxaborolan-2yl)octahydro-4H-inden-4-one (ent-15)

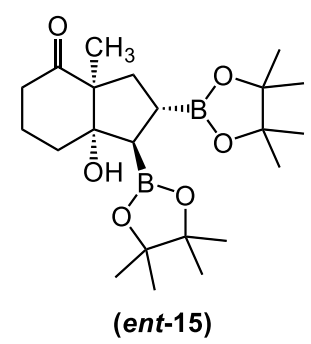

This reaction was run using (S,S)-BDPP ( $4.8 \mathrm{mg}, 0.011 \mathrm{mmol}, 11 \mathrm{~mol} \%)$ instead of furyl-OMebiphep (otherwise according to General Procedure I). Silica gel chromatography (12:1 hex:EtOAc $\rightarrow$ 2:1 hex:EtOAc) afforded (ent-15) as a clear, colorless oil (40.6 mg, 97\% yield, 11:1 $\mathrm{dr}, \sim 85: 15 \mathrm{er})$.

${ }^{1} \mathrm{H}$ NMR (600 MHz, CDCl $)$ ): 2.54-2.49 (td, $13.9 \mathrm{~Hz}, 5.5 \mathrm{~Hz}, 1 \mathrm{H}$ ); 2.30-2.27 (br d, $15.0 \mathrm{~Hz}, 1 \mathrm{H}$ ); 2.19-2.15 (app t, $12.8 \mathrm{~Hz}, 1 \mathrm{H}) ; 2.07-2.00(\mathrm{~m}, 1 \mathrm{H}) ; 1.97-1.91(\mathrm{~m}, 1 \mathrm{H}) ; 1.85-1.80(\mathrm{~m}, 3 \mathrm{H}) ; 1.72-1.68$ $(\mathrm{m}, 2 \mathrm{H}) ; 1.52-1.48(\mathrm{dd}, 13.6 \mathrm{~Hz}, 5.5 \mathrm{~Hz}, 1 \mathrm{H}) ; 1.25(\mathrm{~s}, 6 \mathrm{H}) ; 1.24(\mathrm{~s}, 6 \mathrm{H}) ; 1.21(\mathrm{~s}, 6 \mathrm{H}), 1.20(\mathrm{~s}, 6 \mathrm{H})$; 1.14 (s, 3H). ${ }^{13} \mathrm{C}$ NMR (151 MHz, $\left.\mathrm{CDCl}_{3}\right): 214.7,87.6,83.6,83.3,59.4,37.9,37.5,32.8,25.2,24.9$, 24.7, 24.6, 21.3, 17.4. HRMS (m/z): calcd for $\mathrm{C}_{22} \mathrm{H}_{3} \mathrm{~B}_{2} \mathrm{O}_{6}: 419.2782\left(\mathrm{M}-\mathrm{H}^{+}\right)$; found: 419.2796. IR $\left(\mathrm{v} / \mathrm{cm}^{-1}\right): 2977.6(\mathrm{~s}), 2939.0(\mathrm{~m}), 2875.3(\mathrm{w}), 1698.0(\mathrm{~s}), 1372.1(\mathrm{~s}), 1318.1(\mathrm{~s}), 1142.6(\mathrm{~s}), 967.1(\mathrm{~m})$, $851.4(\mathrm{~m}) \cdot[\alpha]_{\mathrm{D}^{23}}=-1.0^{\circ}\left(\mathrm{c}=5.3, \mathrm{CH}_{2} \mathrm{Cl}_{2}, \mathrm{l}=1 \mathrm{dm}\right)$. 
Diacel CHIRALPAK IC Column: 85:15 hexanes:iPrOH; $1.0 \mathrm{~mL} / \mathrm{min} ; 205 \mathrm{~nm}$.

Racemic material:

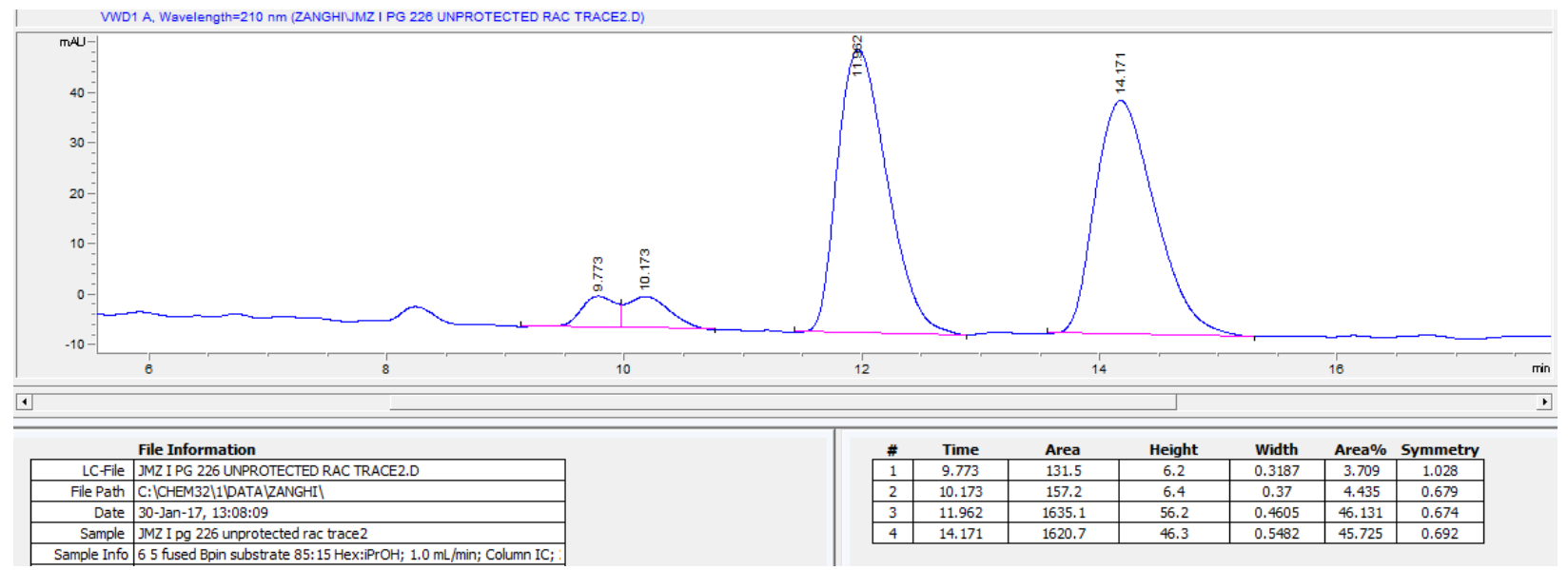

Enantioenriched material:

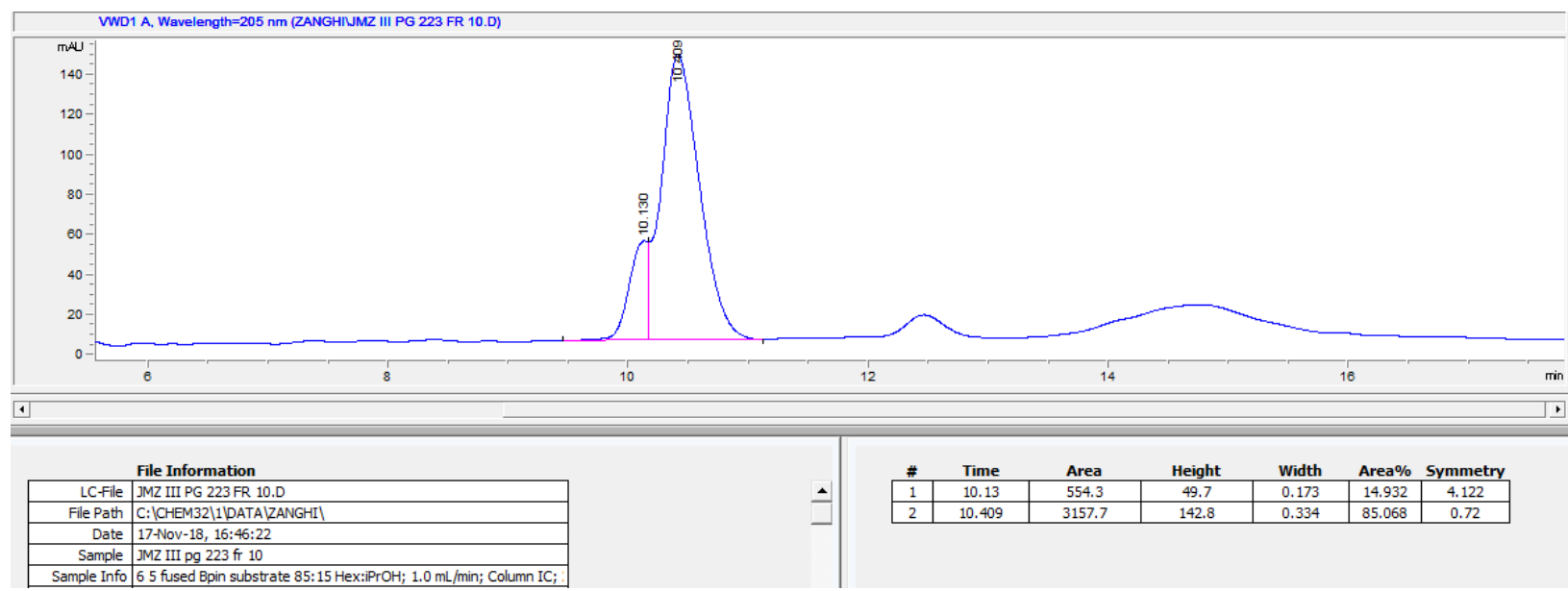

(1R,2R,3aS,7aS)-7a-hydroxy-3a,6,6-trimethyl-1,2-bis(4,4,5,5-tetramethyl-1,3,2-dioxaborolan-2yl)octahydro-4H-inden-4-one ( $3 b)$<smiles>CC1(C)CC(=O)C2(C)CC(B3OC(C)(C)C(C)(C)O3)C(B3OC(C)(C)C(C)(C)O3)C2(C)C1</smiles>

(3b)

This reaction was run using (R)-furyl-OMe-biphep. Silica gel chromatography (15:1 hex:EtOAc $\rightarrow 6: 1$ hex:EtOAc) provided (3b) as a clear, colorless oil $(24.2 \mathrm{mg}, 54 \%$ yield, $>20: 1 \mathrm{dr},>99: 1 \mathrm{er})$ 
which crystallized upon standing at $-20^{\circ} \mathrm{C}$. A crystal was analyzed by single crystal X-ray diffraction (vide infra).

${ }^{1} \mathrm{H}$ NMR (600 MHz, $\left.\mathrm{CDCl}_{3}\right): 2.56(\mathrm{~d}, 13.6 \mathrm{~Hz}, 1 \mathrm{H}) ; 2.20$ (d, $\left.15.0 \mathrm{~Hz}, 1 \mathrm{H}\right) ; 2.09$ (d, $\left.13.6 \mathrm{~Hz}, 1 \mathrm{H}\right)$; $2.04(\mathrm{dd}, 13.2 \mathrm{~Hz}, 7.7 \mathrm{~Hz}, 1 \mathrm{H}) ; 1.92(\mathrm{~s}, 1 \mathrm{H}) ; 1.91$ (d, $13.2 \mathrm{~Hz}, 1 \mathrm{H}) ; 1.79-1.65(\mathrm{~m}, 3 \mathrm{H}), 1.25$ (br s, 24H); 1.14 (s, 3H); 1.04 (s, 3H); 0.99 (s, 3H). ${ }^{13} \mathrm{C} \mathrm{NMR} \mathrm{(151} \mathrm{MHz,} \mathrm{CDCl} 3$ ): 215.6, 88.3, 83.6, 83.4, 58.0, 50.1, 44.9, 39.6, 35.5, 33.1, 28.3, 25.3, 25.2, 24.8, 24.7, 16.6. HRMS (m/z): calcd for $\mathrm{C}_{24} \mathrm{H}_{41} \mathrm{~B}_{2} \mathrm{O}_{6}$ :

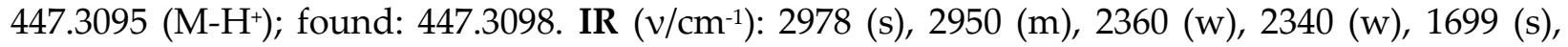
$1471(\mathrm{~m}), 1373(\mathrm{~s}), 1320(\mathrm{~s}), 1213(\mathrm{~m}), 1145(\mathrm{~s}), 1059(\mathrm{~m}), 965(\mathrm{~m}), 862(\mathrm{~m}) .[\alpha]_{\mathrm{D}}^{23}=+25.9^{\circ}(\mathrm{c}=1.06$, $\left.\mathrm{CH}_{2} \mathrm{Cl}_{2}, \mathrm{l}=1 \mathrm{dm}\right)$.

Diacel CHIRALPAK IC Column: 90:10 hexanes:iPrOH; $1.0 \mathrm{~mL} / \mathrm{min} ; 205 \mathrm{~nm}$.

\section{Racemic material: (mixture of diastereomers)}

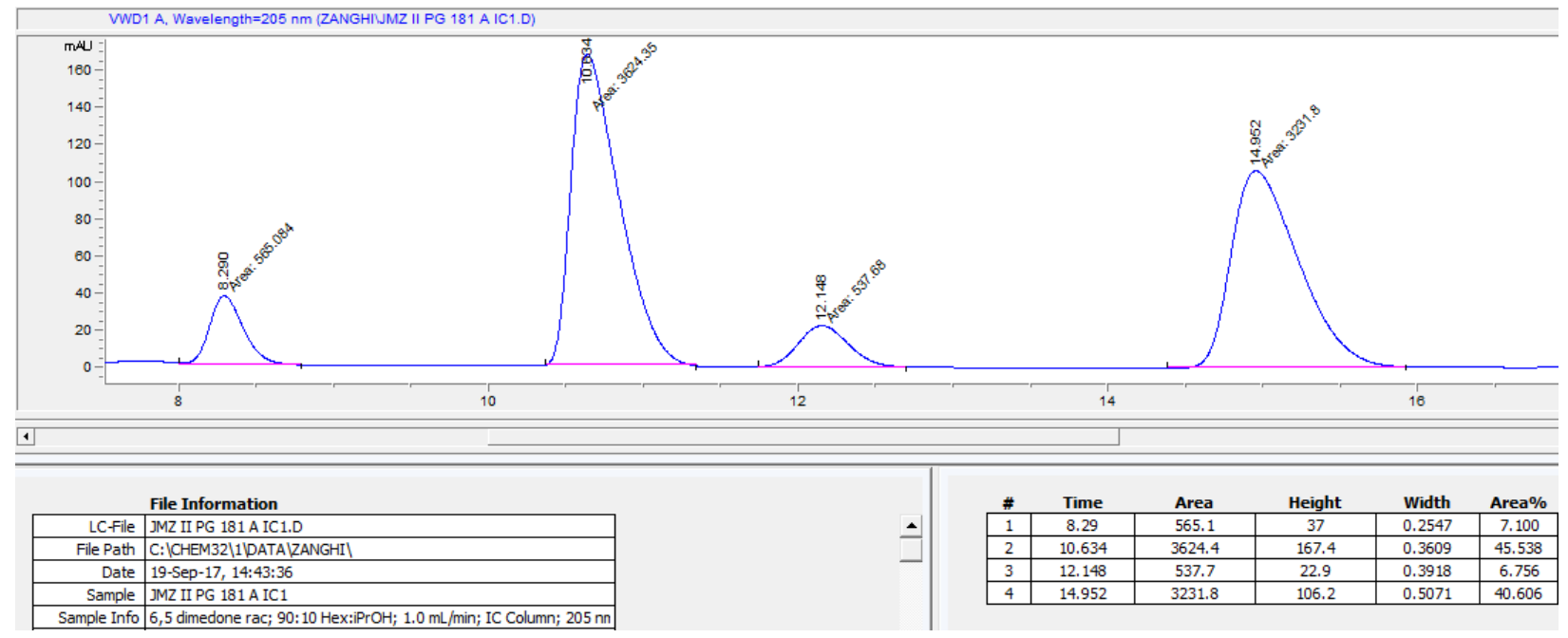

\section{Enantioenriched material:}

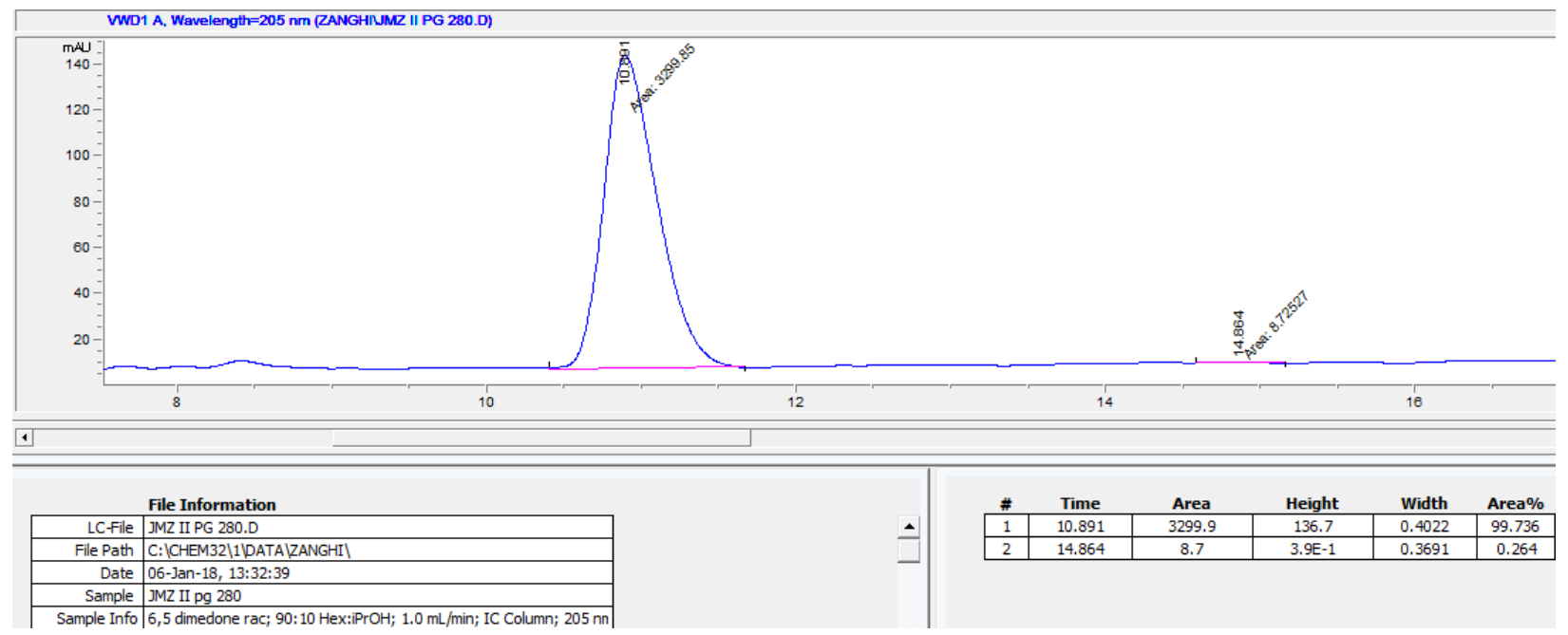


(1R,2S,3aR,7aS)-7a-hydroxy-3a-(3-methylbut-2-en-1-yl)-1,2-bis(4,4,5,5-tetramethyl-1,3,2dioxaborolan-2-yl)octahydro-4H-inden-4-one (3c)

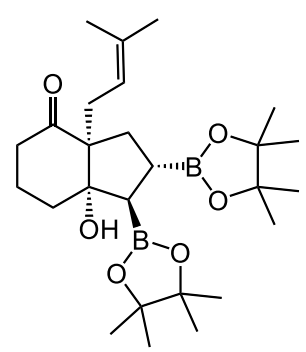

(3c)

This reaction was run using (S)-furyl-OMe-biphep. Silica gel chromatography $(20: 1 \rightarrow 8: 1$ hexanes:EtOAc) provided (3c) as a clear, colorless oil which crystallized at $-20{ }^{\circ} \mathrm{C} .(23.2 \mathrm{mg}, 49 \%$ yield, 5:1 dr, 98:2 er (maj), >99:1 er (min)).

${ }^{1} \mathrm{H}$ NMR (600 MHz, $\mathrm{CDCl}_{3}$ ): 5.28 (min. diast., t, $7.3 \mathrm{~Hz}, 0.21 \mathrm{H}$ ); 5.21 (maj. diast., t, $6.2 \mathrm{~Hz}, 1 \mathrm{H}$ ); 2.55-2.28 (m, 7H); 2.27-2.18 (m, 1H); 2.13-1.99 (m, 2H); 1.85-1.1.61 (m, $14 \mathrm{H}) ; 1.57-1.48(\mathrm{~m}, 2 \mathrm{H})$; 1.32-1.17 (m, 35H). ${ }^{13} \mathrm{C}$ NMR (214 MHz, $\left.\mathrm{CDCl}_{3}\right)$ : 214.4, 133.6, 122.0, 88.4, 83.1, 63.0, 37.4, 36.2, 33.2, 31.9, 31.6, 29.1, 26.0, 25.0, 24.8, 24.6, 22.7, 20.7, 20.3, 18.0, 14.1, 11.4. HRMS (m/z): calcd for $\mathrm{C}_{26} \mathrm{H}_{45} \mathrm{~B}_{2} \mathrm{O}_{6}{ }^{+}: 475.3397\left(\mathrm{M}+\mathrm{H}^{+}\right)$; found: 475.3380. IR $\left(\mathrm{v} / \mathrm{cm}^{-1}\right): 2977.6(\mathrm{~m}), 2931.3(\mathrm{w}), 1699.0(\mathrm{~s})$, $1372.1(\mathrm{~s}), 1144.5(\mathrm{~s}), 967.1(\mathrm{~m}), 851.4(\mathrm{~m}) .[\alpha]_{\mathrm{D}^{23}}=+5.3^{\circ}\left(\mathrm{c}=1.14, \mathrm{CH}_{2} \mathrm{Cl}_{2}, \mathrm{l}=1 \mathrm{dm}\right)$.

Phenomenex Lux Cellulose-1 OD Column: 97:3 CO2:iPrOH; $1.0 \mathrm{~mL} / \mathrm{min} ; 210 \mathrm{~nm}$.

\section{Racemic material: (mixture of diastereomers)}

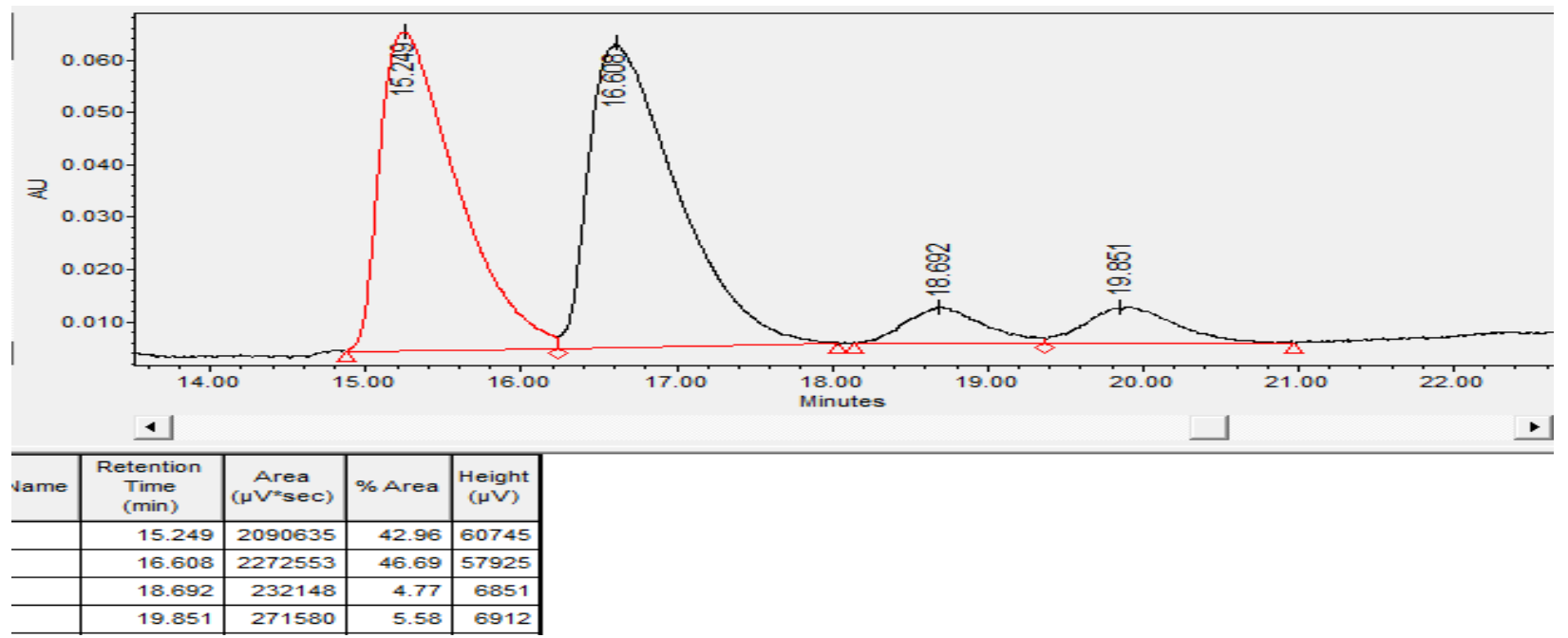


Enantioenriched material:

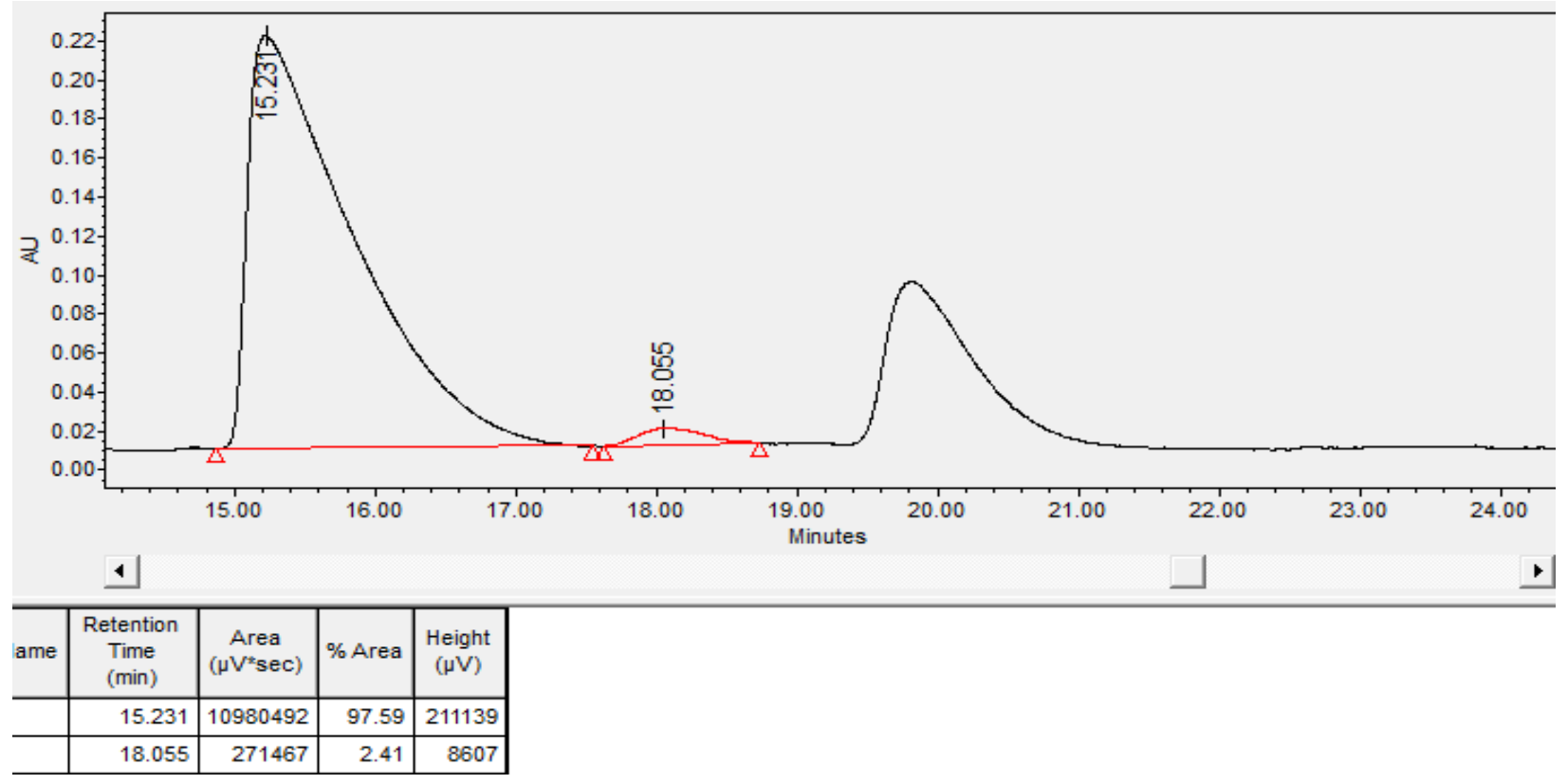

(1R,2S,3aR,7aS)-3a-benzyl-7a-hydroxy-1,2-bis(4,4,5,5-tetramethyl-1,3,2-dioxaborolan-2yl)octahydro-4H-inden-4-one (3d)

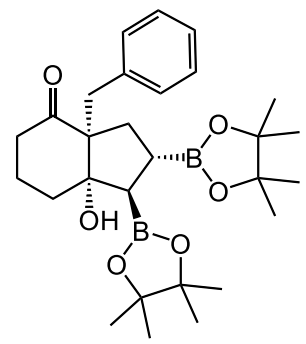

(3d)

This reaction was run using (S)-furyl-OMe-biphep. Silica gel chromatography $(15: 1 \rightarrow$ 8:1 hexanes:EtOAc) provided (3d) as a clear, colorless oil (16.1 mg, 32\% yield, >20:1 dr, 96:4 er).

${ }^{1}$ H NMR (400 MHz, $\left.\mathrm{CDCl}_{3}\right):$ 7.25-7.11 (m, 5H); $3.16(\mathrm{~d}, 13.9 \mathrm{~Hz}, 1 \mathrm{H}) ; 2.93(\mathrm{~d}, 13.9 \mathrm{~Hz}, 1 \mathrm{H}) ; 2.41$ (m, 2H); 2.20 (dd, 13.4 Hz, $9.3 \mathrm{~Hz}, 1 \mathrm{H}) ; 2.10-1.97(\mathrm{~m}, 2 \mathrm{H}) ; 1.92-1.69(\mathrm{~m}, 5 \mathrm{H}) ; 1.62(\mathrm{dd}, 13.2 \mathrm{~Hz}, 9.3$ $\mathrm{Hz}, 1 \mathrm{H}) ; 1.35(\mathrm{~m}, 3 \mathrm{H}) ; 1.23(\mathrm{~m}, 24 \mathrm{H}) .{ }^{13} \mathrm{C}$ NMR (214 MHz, $\left.\mathrm{CDCl}_{3}\right): 214.2,139.0,130.9,128.0$, 126.2, 87.9, 83.6, 83.3, 65.5, 39.0, 38.0, 35.0, 33.9, 25.2, 25.0, 24.8, 24.7, 20.1. HRMS (m/z): calcd for $\mathrm{C}_{28} \mathrm{H}_{41} \mathrm{~B}_{2} \mathrm{O}_{6}: 495.3095\left(\mathrm{M}-\mathrm{H}^{+}\right)$; found: 495.3106. IR (v/cm-1): $2977.6(\mathrm{~m}), 2933.2(\mathrm{~m}), 1698.9(\mathrm{~s})$, $1380.8(\mathrm{~s}), 1371.1(\mathrm{~s}), 1317.1(\mathrm{~s}), 1144.6(\mathrm{~s}), 967.1(\mathrm{w}), 851.4(\mathrm{w}), 701.0(\mathrm{w}) .[\alpha]_{\mathrm{D}^{23}}=-11.7^{\circ}(\mathrm{c}=$ $\left.0.72, \mathrm{CH}_{2} \mathrm{Cl}_{2}, 1=1 \mathrm{dm}\right)$. 
Phenomenex Lux Cellulose-1 OD Column: 90:10 CO2:iPrOH; 1.0 mL/min; 210 nm.

\section{Racemic material:}

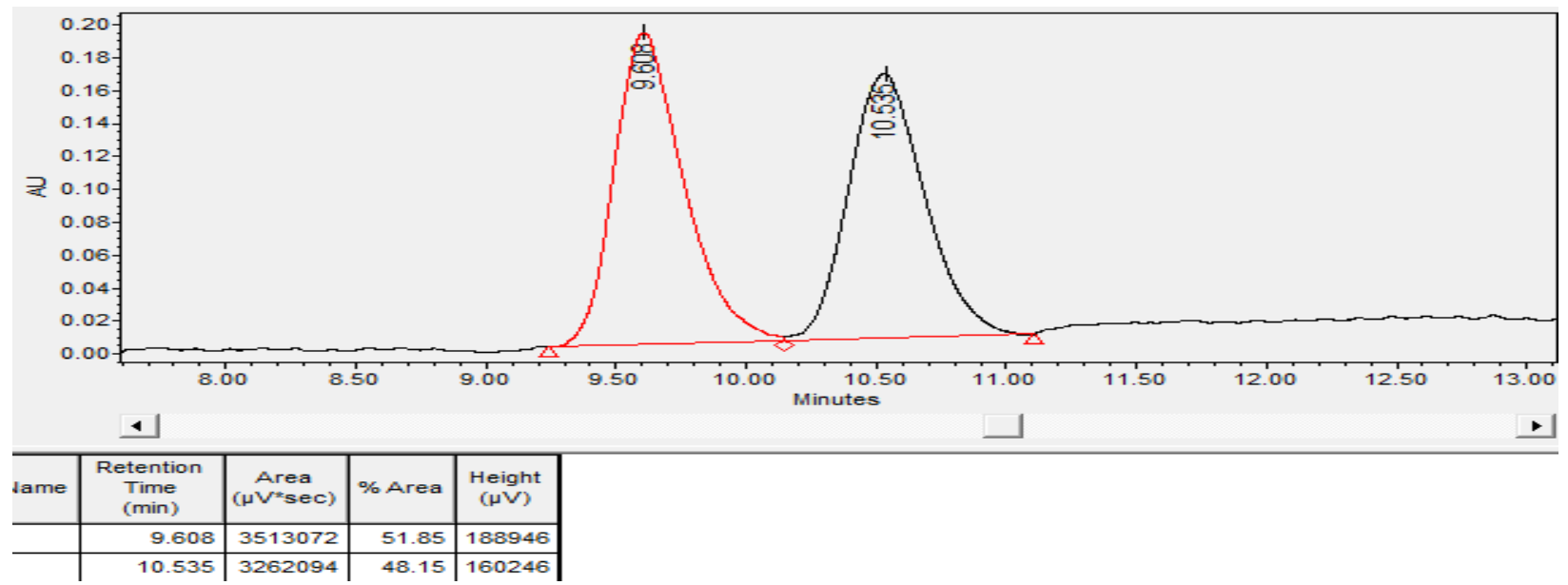

Enantioenriched material:

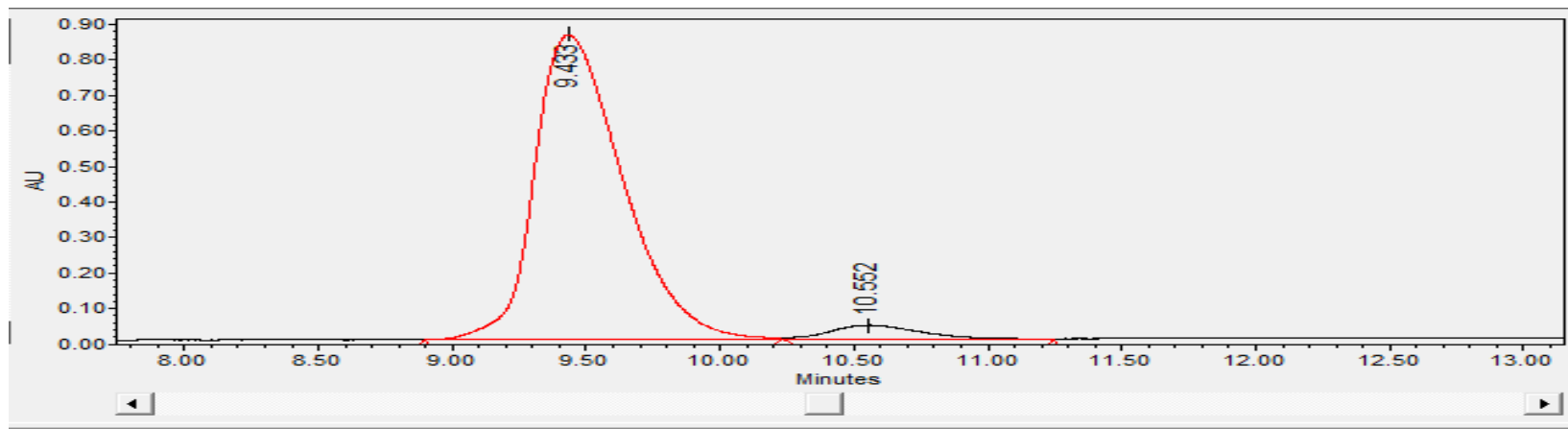

\begin{tabular}{r|r|r|r|r|}
\hline Vame & $\begin{array}{c}\text { Retention } \\
\text { Time } \\
(\mathrm{min})\end{array}$ & $\begin{array}{c}\text { Area } \\
\left(\mu \mathrm{V}^{*} \text { sec) }\right.\end{array}$ & \% Area & $\begin{array}{c}\text { Height } \\
\left(\mu V^{\prime}\right)\end{array}$ \\
\hline & 9.433 & 19598074 & 95.67 & 858288 \\
\hline & 10.552 & 887553 & 4.33 & 39028 \\
\hline
\end{tabular}

(1R,2S,3aR,7aS)-7a-hydroxy-1,2-bis(4,4,5,5-tetramethyl-1,3,2-dioxaborolan-2-yl)-3a-(thiophen3-ylmethyl)octahydro-4H-inden-4-one (3e)

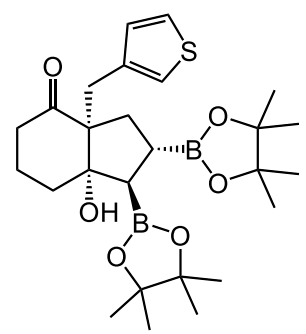

(3e)

This reaction was run using (S)-furyl-OMe-biphep. Analysis of crude reaction material revealed $65 \%$ NMR yield as a 3:2 mixture of diastereomers. The minor diastereomer was found to 
decompose on silica gel, resulting in high dr but low isolated yield. Silica gel chromatography $(15: 1 \rightarrow$ 8:1 hex:EtOAc) provided (3e) as a clear, colorless oil $(12.4 \mathrm{mg}, 25 \%$ yield, >20:1 dr, 94:6 er). ${ }^{1} \mathrm{H}$ NMR (500 MHz, CDCl 3 ): $7.16(\mathrm{dd}, 4.9 \mathrm{~Hz}, 3.4 \mathrm{~Hz}, 1 \mathrm{H}) ; 7.06$ (br s, $\left.1 \mathrm{H}\right) ; 7.02$ (d, $\left.4.9 \mathrm{~Hz}\right)$; 3.18 (d, $14.6 \mathrm{~Hz}, 1 \mathrm{H}) ; 2.94$ (d, $14.3 \mathrm{~Hz}, 1 \mathrm{H}) ; 2.45$ (m, 1H); 2.36-2.31 (app dt, $15.0 \mathrm{~Hz}, 4.6 \mathrm{~Hz}) ; 2.19$ $(\mathrm{m}, 1 \mathrm{H}) ; 2.02(\mathrm{~m}, 1 \mathrm{H}) ; 1.90-1.75(\mathrm{~m}, 3 \mathrm{H}) ; 1.75-1.56(\mathrm{~m}, 3 \mathrm{H}) ; 1.49(\mathrm{~m}, 1 \mathrm{H}) ; 1.25(\mathrm{~s}, 6 \mathrm{H}) ; 1.23(\mathrm{~s}, 6 \mathrm{H})$; 1.23 (s, 6H); 1.20 (s, 6H). $\left.{ }^{13} \mathrm{C} \mathrm{NMR} \mathrm{(214} \mathrm{MHz,} \mathrm{CDCl}_{3}\right): 214.5,139.5,130.8,124.6,123.5,88.5,83.6$, 83.3, 64.7, 38.0, 35.2, 33.9, 33.3, 25.2, 25.1, 24.73, 24.71, 20.6. HRMS (m/z): calcd for $\mathrm{C}_{26} \mathrm{H}_{39} \mathrm{~B}_{2} \mathrm{O}_{6} \mathrm{~S}:$ :

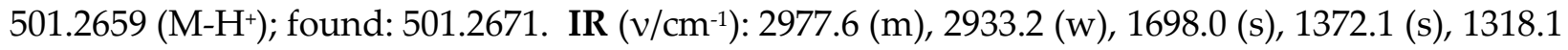
(s), $1143.6(\mathrm{~s}), 966.2(\mathrm{~m}), 851.4(\mathrm{~m}) .[\alpha]_{\mathrm{D}^{23}}=-1.5^{\circ}\left(\mathrm{c}=0.72, \mathrm{CH}_{2} \mathrm{Cl}_{2}, 1=1 \mathrm{dm}\right)$.

Diacel CHIRALPAK IA Column: 90:10 hexanes:iPrOH; $1.0 \mathrm{~mL} / \mathrm{min} ; 210 \mathrm{~nm}$.

\section{Racemic material:}

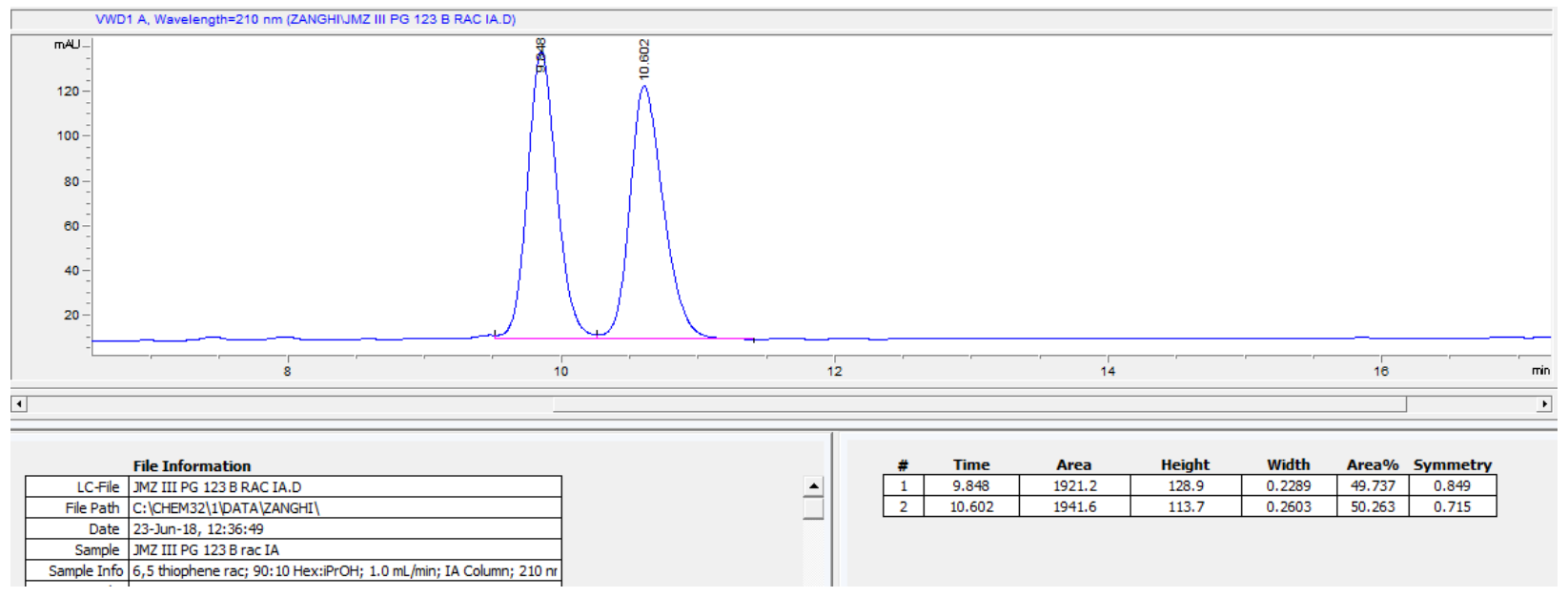

\section{Enantioenriched material:}

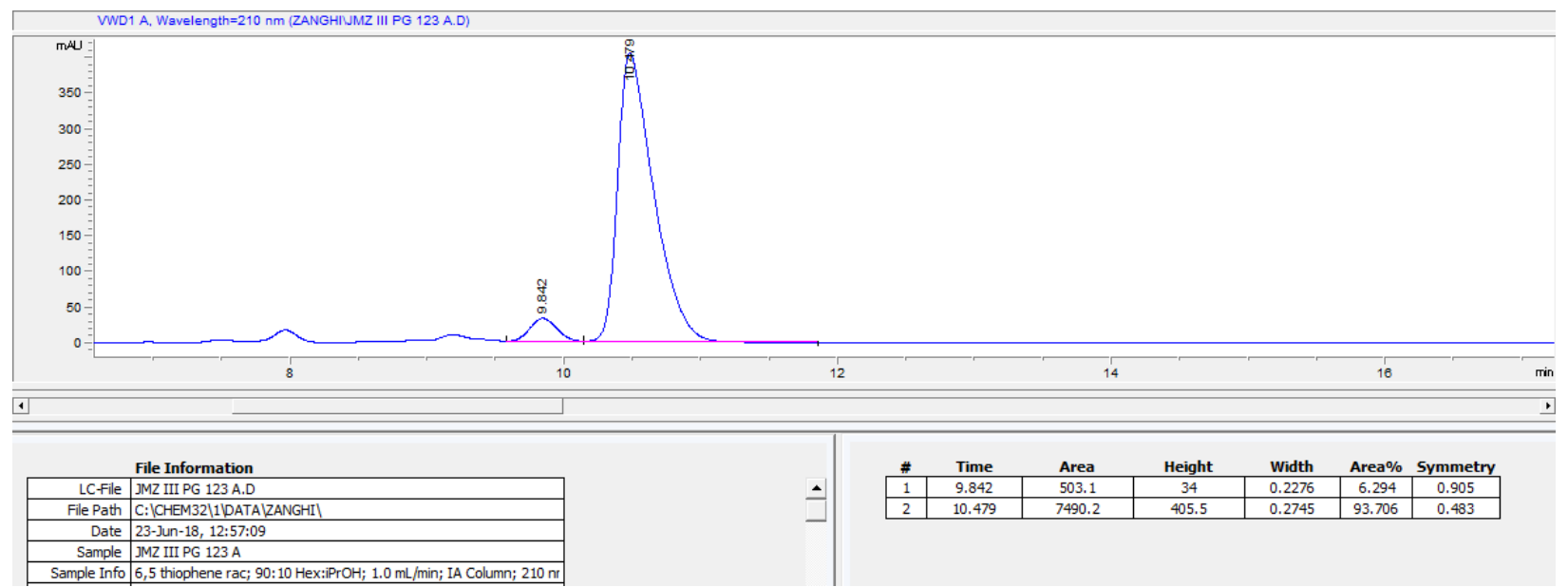


(1R,2S,3aR,7aS)-3a-allyl-7a-hydroxy-1,2-bis(4,4,5,5-tetramethyl-1,3,2-dioxaborolan-2-

yl)octahydro-4H-inden-4-one (3f)

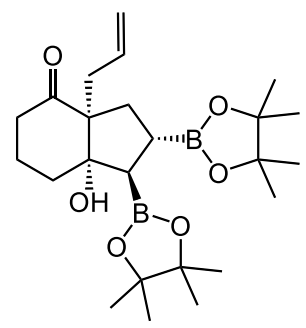

(3f)

This reaction was run using (S)-furyl-OMe-biphep. Silica gel chromatography (75:1 hex:EtOAc + $5 \mathrm{vol} \% \mathrm{NEt}_{3} \rightarrow 25: 1$ hex:EtOAc +5 vol\% NEt 3 ) provided (3f) as a clear, colorless oil (20.6 mg, 46\% yield, 17:1 dr, 88:12 er).

${ }^{1}$ H NMR (600 MHz, $\left.\mathrm{CDCl}_{3}\right)$ : 5.99-5.92 (m, 1H); 5.12-5.10 (d, $\left.16.1 \mathrm{~Hz}, 1 \mathrm{H}\right) ;$ 5.05-5.03 (d, $10.3 \mathrm{~Hz}$, $1 \mathrm{H}) ; 2.58-2.55(\mathrm{dd}, 14.3 \mathrm{~Hz}, 7.3 \mathrm{~Hz}, 1 \mathrm{H}) ; 2.50-2.34(\mathrm{~m}, 3 \mathrm{H}) ; 2.24-2.20(\mathrm{dd}, 13.6 \mathrm{~Hz}, 11.0 \mathrm{~Hz}, 1 \mathrm{H})$; $2.16(\mathrm{~s}, \mathrm{OH}, 1 \mathrm{H}) ; 2.13-2.05(\mathrm{~m}, 1 \mathrm{H}) ; 1.89-1.73(\mathrm{~m}, 4 \mathrm{H}) ; 1.64-1.62(\mathrm{~m}, 1 \mathrm{H}) ; 1.59-1.54(\mathrm{~m}, 1 \mathrm{H}) ; 1.27$ (s, $6 \mathrm{H}) ; 1.26(\mathrm{~s}, 6 \mathrm{H}) ; 1.24(\mathrm{~s}, 6 \mathrm{H}) ; 1.23$ (s, 6H). ${ }^{13} \mathrm{C}$ NMR (151 MHz, $\left.\mathrm{CDCl}_{3}\right)$ : 214.3, 137.3, 117.3, 88.6, 83.5, 83.3, 63.1, 38.0, 37.7, 35.1, 33.6, 25.2, 25.0, 24.70, 24.67, 20.6. HRMS $(\mathrm{m} / \mathrm{z})$ : calcd for $\mathrm{C}_{24} \mathrm{H}_{41} \mathrm{~B}_{2} \mathrm{O}_{6}{ }^{+}: 447.3084\left(\mathrm{M}+\mathrm{H}^{+}\right)$; found: 447.3079. IR (v/cm $\left.{ }^{-1}\right): 2976.6(\mathrm{~m}), 2927.4(\mathrm{w}), 2360.4(\mathrm{~m})$, $2341.2(\mathrm{~m}), 1698.0$ (s), 1372.1 (s), 1321.0 (s), 1214.9 (w), 1144.5 (s), 968.1 (w), 858.2 (w), $668.2(\mathrm{w})$. $[\alpha]_{\mathrm{D}^{23}}=+0.2^{\circ}\left(\mathrm{c}=0.48, \mathrm{CH}_{2} \mathrm{Cl}_{2}, 1=1 \mathrm{dm}\right)$.

Diacel CHIRALPAK IC Column: 92:8 hexanes:iPrOH; $1.0 \mathrm{~mL} / \mathrm{min} ; 205 \mathrm{~nm}$.

\section{Racemic material:}

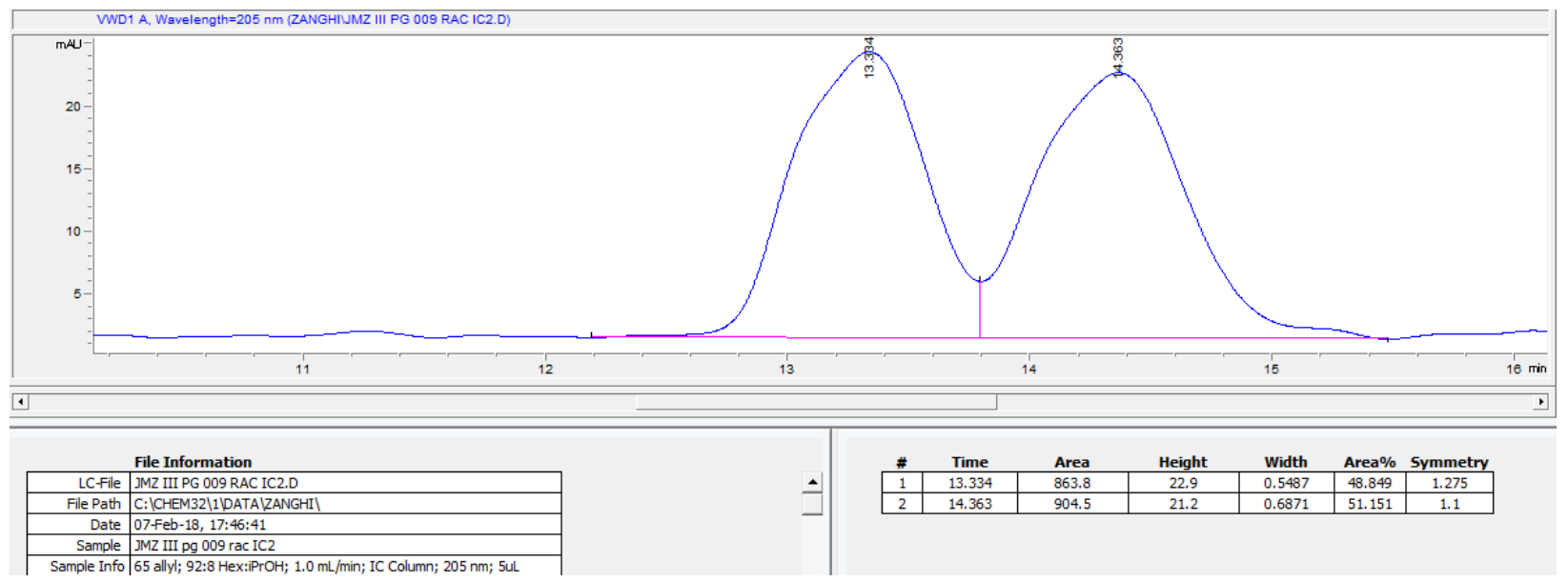




\section{Enantioenriched material:}

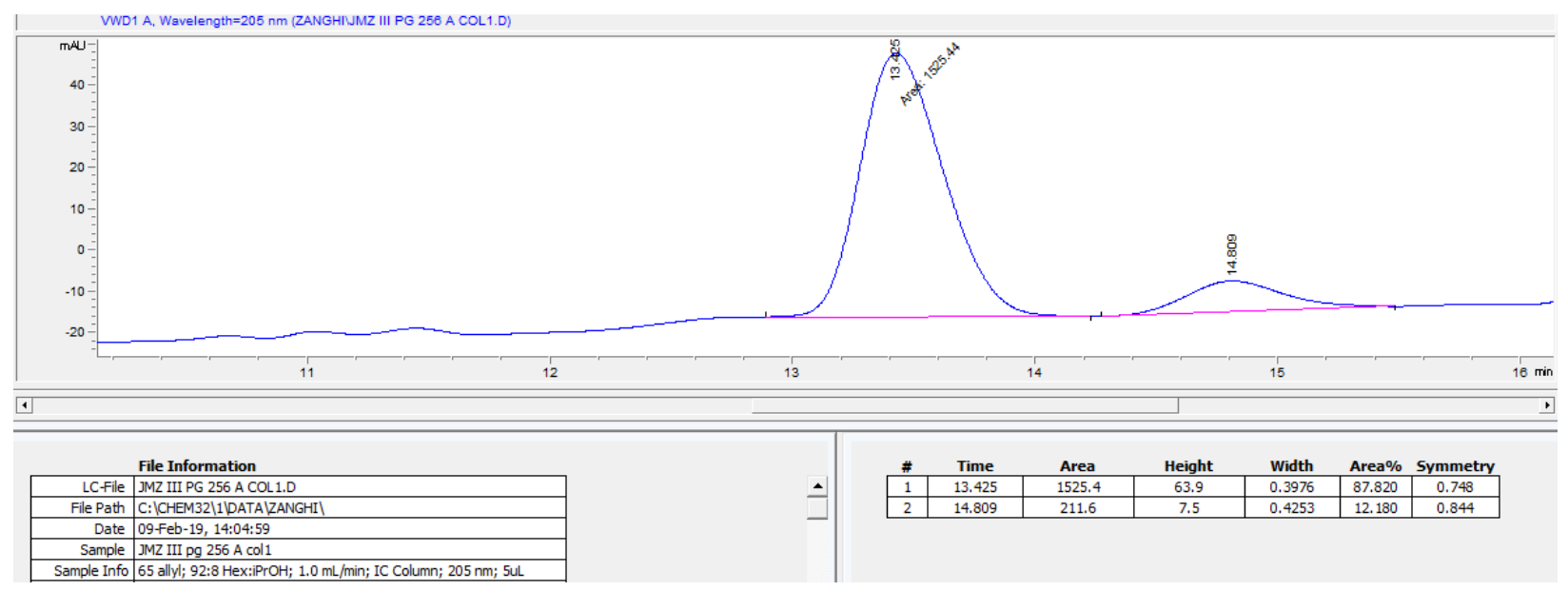

(3aR,4S,5R,6aR)-3a-hydroxy-6a-methyl-4,5-bis(4,4,5,5-tetramethyl-1,3,2-dioxaborolan-2yl)hexahydropentalen-1(2H)-one (5a)

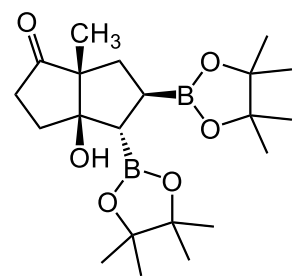

(5a)

Silica gel chromatography: 100\% DCM $\rightarrow$ 98.5:1.5 DCM:i-PrOH. Initial column chromatography provided the tris-boronate, which was subjected to hydrolysis $(250 \mu \mathrm{L} 8 \mathrm{M} \mathrm{HCl}(a q)+1 \mathrm{~mL}$ THF, $22{ }^{\circ} \mathrm{C}, 2 \mathrm{~h}$ ). Extraction with EtOAc and column chromatography under the same conditions afforded the bis-boronate (5a) as a white solid $(28.1 \mathrm{mg}, 69 \%$ yield, 2:1 dr, 74:26 er (major diastereomer), 90:10 er (minor diastereomer)).

${ }^{1}$ H NMR (400 MHz, $\left.\mathrm{CDCl}_{3}\right)$ : 2.54-2.39 (m, 2H); 2.37-2.25 (m, 1H); 2.17 (s, 0.4H); 2.04-1.89 (m, $6 \mathrm{H}) ; 1.90-1.77(\mathrm{~m}, 1.5 \mathrm{H}) ; 1.74-1.68(\mathrm{~m}, 0.5 \mathrm{H}) ; 1.67-1.60(\mathrm{~m}, 1.5 \mathrm{H}) ; 1.50(\mathrm{dd}, 13.7 \mathrm{~Hz}, 9.8 \mathrm{~Hz}, 1 \mathrm{H})$; 1.32-1.16 (m, 47H); 1.05 (s, 1.6H, $\mathrm{CH}_{3}$ min. diast.); 1.02 (s, 3H, $\mathrm{CH}_{3}$ maj. diast.). ${ }^{13} \mathrm{C}$ NMR (214 MHz, $\mathrm{CDCl}_{3}$ ): 222.7 (maj. diast.), 221.6 (min. diast.), 90.5, 90.0, 83.72, 83.66, 83.5, 83.3, 77.4, 59.4, 39.2, 37.6, 36.6, 35.4, 32.4, 32.1, 25.3, 25.2, 25.1, 24.82, 24.78, 24.72, 24.70, 17.5, 14.8. HRMS (m/z): calcd for $\mathrm{C}_{21} \mathrm{H}_{35} \mathrm{~B}_{2} \mathrm{O}_{6}: 405.2625\left(\mathrm{M}-\mathrm{H}^{+}\right)$; found: 405.2633. IR (v/cm $\left.{ }^{-1}\right): 2978(\mathrm{~s}), 2932(\mathrm{~m}), 2360(\mathrm{~m}), 2341$

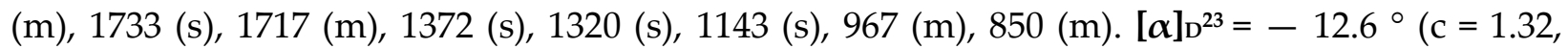
$\left.\mathrm{CH}_{2} \mathrm{Cl}_{2}, \mathrm{l}=1 \mathrm{dm}\right)$. 
Diacel CHIRALPAK IA Column: 97:3 hexanes:iPrOH; $1.0 \mathrm{~mL} / \mathrm{min} ; 205 \mathrm{~nm}$.

\section{Racemic material:}

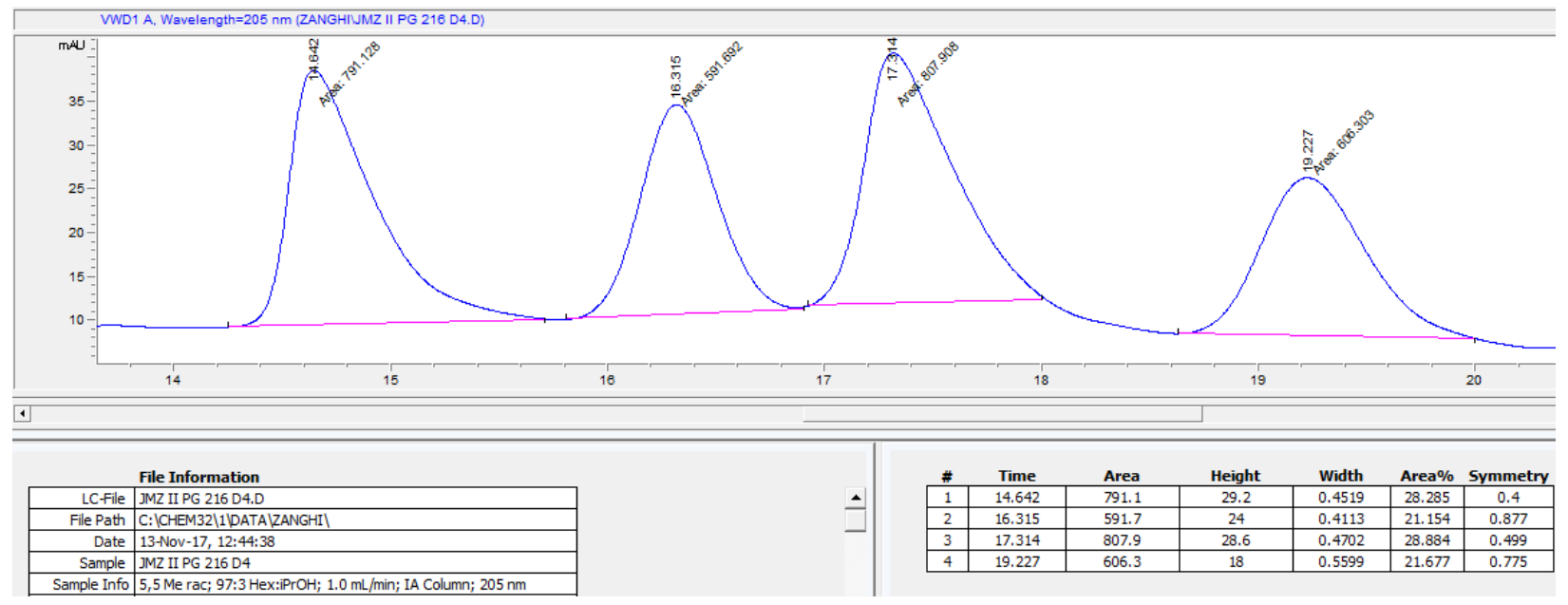

Enantioenriched material:

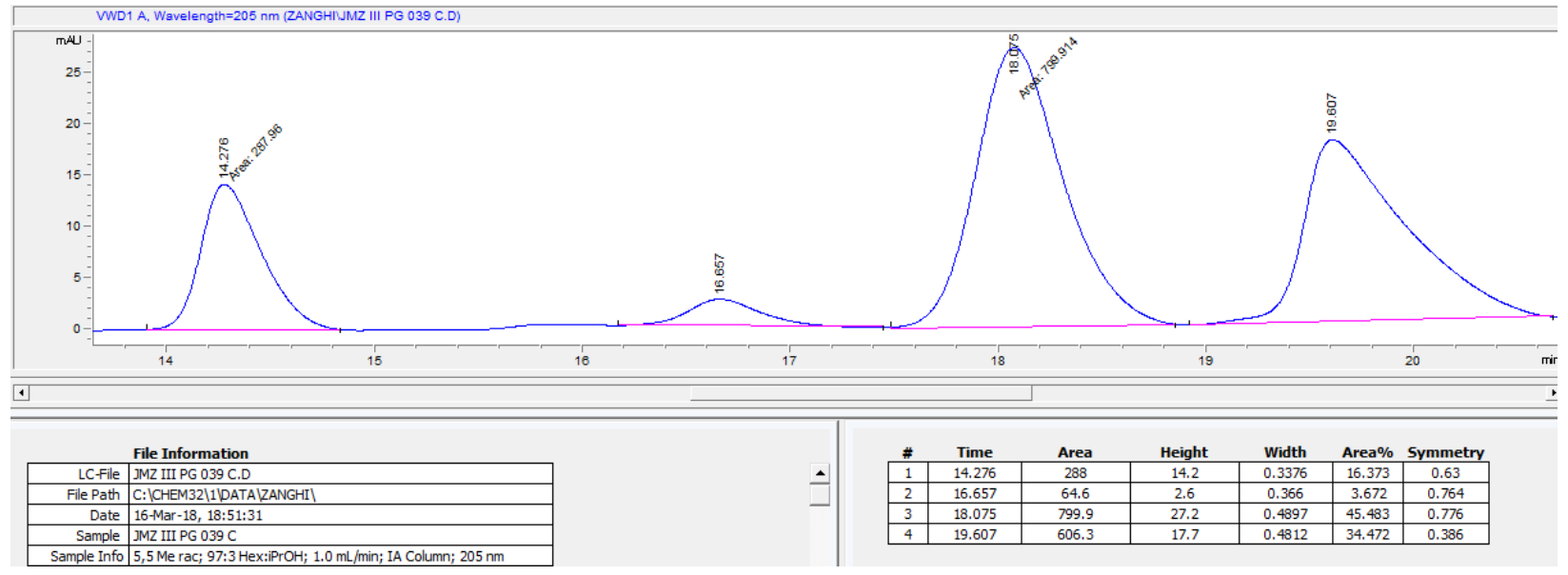




\section{(3aR,4S,5R,6aS)-6a-allyl-3a-hydroxy-4,5-bis(4,4,5,5-tetramethyl-1,3,2-dioxaborolan-2-}

yl)hexahydropentalen-1(2H)-one (5b)

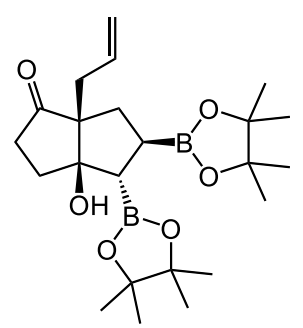

(5b)

Silica gel chromatography (15:1 hex:EtOAc $\rightarrow$ 8:1 hex:EtOAc) afforded $(\mathbf{5 b})$ as a white solid (24.5 $\mathrm{mg}$, 57\% yield, >20:1 dr, 89:11 er).

${ }^{1}$ H NMR (600 MHz, $\left.\mathrm{CDCl}_{3}\right)$ : 6.00-5.93 (m, 1H); 5.10-5.04 (m, 2H); 2.52-2.45 (dt, $17.6 \mathrm{~Hz}, 10.3 \mathrm{~Hz}$, $1 \mathrm{H}) ; 2.35-2.25$ (m, 3H); 2.17 (br s, 1H); 2.00-1.88 (m, 2H);1.72-1.68 (dd, $13.6 \mathrm{~Hz}, 11.0 \mathrm{~Hz}, 1 \mathrm{H}) 1.61$ (d, $13.2 \mathrm{~Hz}, 1 \mathrm{H}) ; 1.25(\mathrm{~s}, 6 \mathrm{H}) ; 1.24(\mathrm{~s}, 6 \mathrm{H}), 1.21$ (s, 6H); $1.20(\mathrm{~s}, 6 \mathrm{H}) .{ }^{13} \mathrm{C}$ NMR $\left(151 \mathrm{MHz}, \mathrm{CDCl}_{3}\right)$ : 222.1; 135.5, 118.0, 90.6, 83.6, 83.3, 62.2, 37.52, 37.46, 37.0, 33.2, 25.1, 24.9, 24.8, 24.7. HRMS (m/z): calcd for $\mathrm{C}_{23} \mathrm{H}_{39} \mathrm{~B}_{2} \mathrm{O}_{6}{ }^{+}: 433.2927\left(\mathrm{M}+\mathrm{H}^{+}\right)$; found: 433.2910. IR (v/cm $\left.{ }^{-1}\right): 2978(\mathrm{~s}), 2929(\mathrm{~m}), 2360(\mathrm{w})$, $2341(\mathrm{w}), 1733$ (s), $1416(\mathrm{~m}), 1381$ (s), 1320 (s), $1143(\mathrm{~s}), 969(\mathrm{~m}), 850(\mathrm{~m}) .[\alpha]_{\mathrm{D}}^{23}=-27.5^{\circ}(\mathrm{c}=1.26$, $\left.\mathrm{CH}_{2} \mathrm{Cl}_{2}, \mathrm{l}=1 \mathrm{dm}\right)$.

Diacel CHIRALPAK IA Column: 97:3 hexanes:iPrOH; 1.0 mL/min; 205 nm.

\section{Racemic material:}

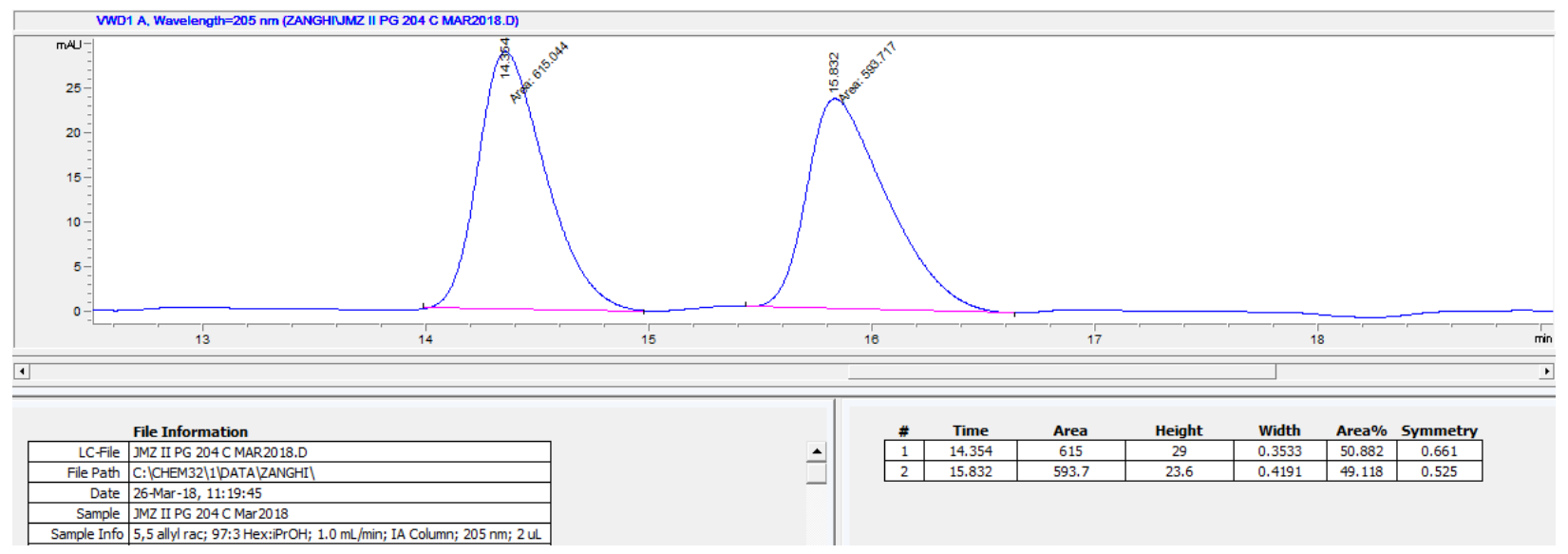




\section{Enantioenriched material:}

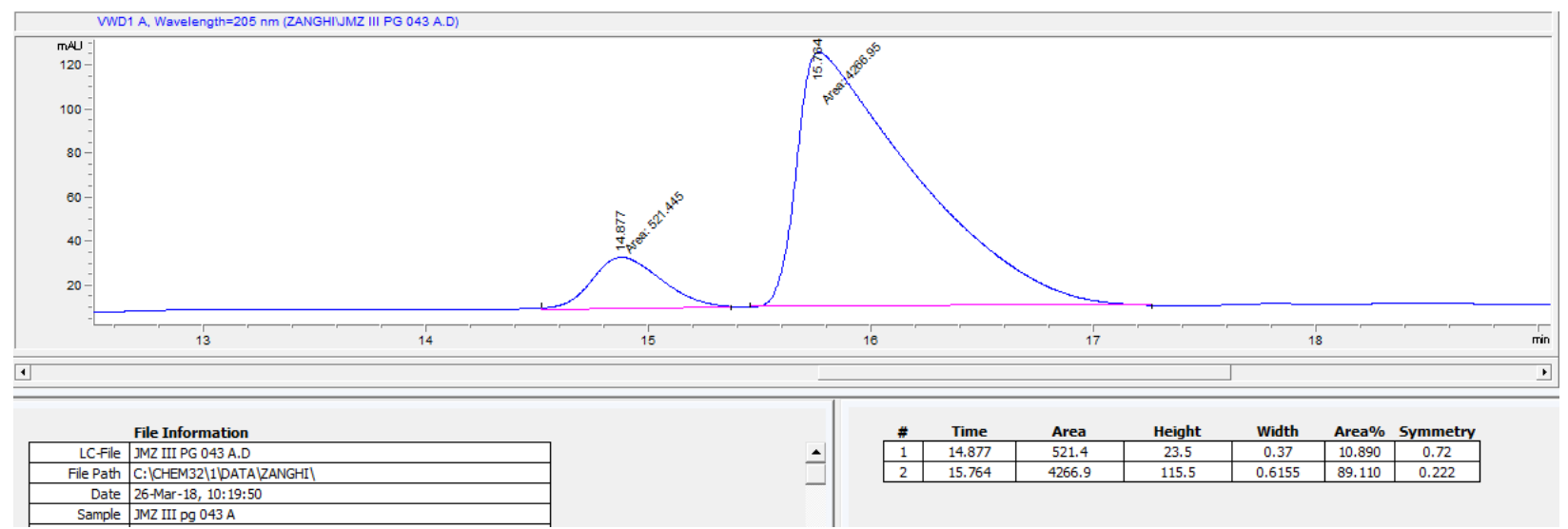

(3aR,4S,5R,6aR)-3a-hydroxy-6a-propyl-4,5-bis(4,4,5,5-tetramethyl-1,3,2-dioxaborolan-2yl)hexahydropentalen-1(2H)-one (5c)

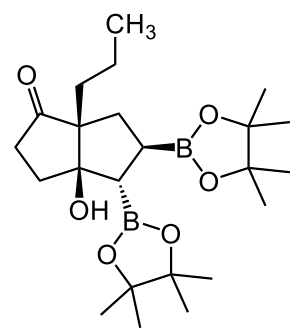

(5c)

Silica gel chromatography (15:1 hex:EtOAc $\rightarrow$ 10: 1 hex:EtOAc) afforded $(5 c)$ as a white solid ( $27.6 \mathrm{mg}, 64 \%$ yield, $>20: 1 \mathrm{dr}, 94: 6 \mathrm{er}$ ). A single recrystallization from hot hexanes provided (5c) in $>20: 1 \mathrm{dr}$ and 97.5:2.5 er.

${ }^{1} \mathrm{H}$ NMR (600 MHz, $\left.\mathrm{CDCl}_{3}\right)$ : 2.54-2.47 (dt, $\left.17.6 \mathrm{~Hz}, 10.3 \mathrm{~Hz}, 1 \mathrm{H}\right)$; 2.24-2.19 (ddd, $17.6 \mathrm{~Hz}, 7.7 \mathrm{~Hz}$, $5.1 \mathrm{~Hz}, 1 \mathrm{H}) ; 2.17(\mathrm{~s}, 1 \mathrm{H}) ; 2.05-1.98(\mathrm{~m}, 2 \mathrm{H}) ; 1.96-1.90(\mathrm{~m}, 2 \mathrm{H}) ; 1.60-1.35$ (m, 4H); 1.25 (s, $6 \mathrm{H}) ; 1.24$ $(\mathrm{s}, 6 \mathrm{H}) ; 1.21(\mathrm{~s}, 6 \mathrm{H}) ; 1.20(\mathrm{~s}, 6 \mathrm{H}) ; 1.14-1.08(\mathrm{~m}, 1 \mathrm{H}) ; 0.87-0.84(\mathrm{t}, 7.0 \mathrm{~Hz}, 3 \mathrm{H}) .{ }^{13} \mathrm{C}$ NMR $(214 \mathrm{MHz}$, $\left.\mathrm{CDCl}_{3}\right)$ : 222.6, 90.0, 83.7, 83.3, 62.5, 38.1, 37.8, 35.6, 33.7, 25.2, 24.9, 24.81, 24.76, 18.0, 15.1. HRMS

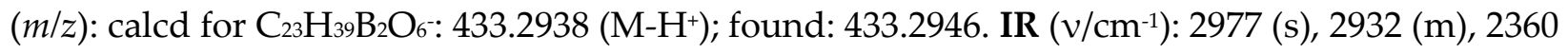
(w), $2331(\mathrm{w}), 1733(\mathrm{~s}), 1717(\mathrm{~m}), 1373(\mathrm{~s}), 1319(\mathrm{~s}), 1143(\mathrm{~s}), 969(\mathrm{~m}), 850(\mathrm{~m}) .[\alpha]_{\mathrm{D}^{23}}=-16.4^{\circ}(\mathrm{c}=$ $\left.1.34, \mathrm{CH}_{2} \mathrm{Cl}_{2}, \mathrm{l}=1 \mathrm{dm}\right)$. 
Diacel CHIRALPAK IA Column: 95:5 hexanes:iPrOH; 1.0 mL/min; 205 nm.

\section{Racemic material:}

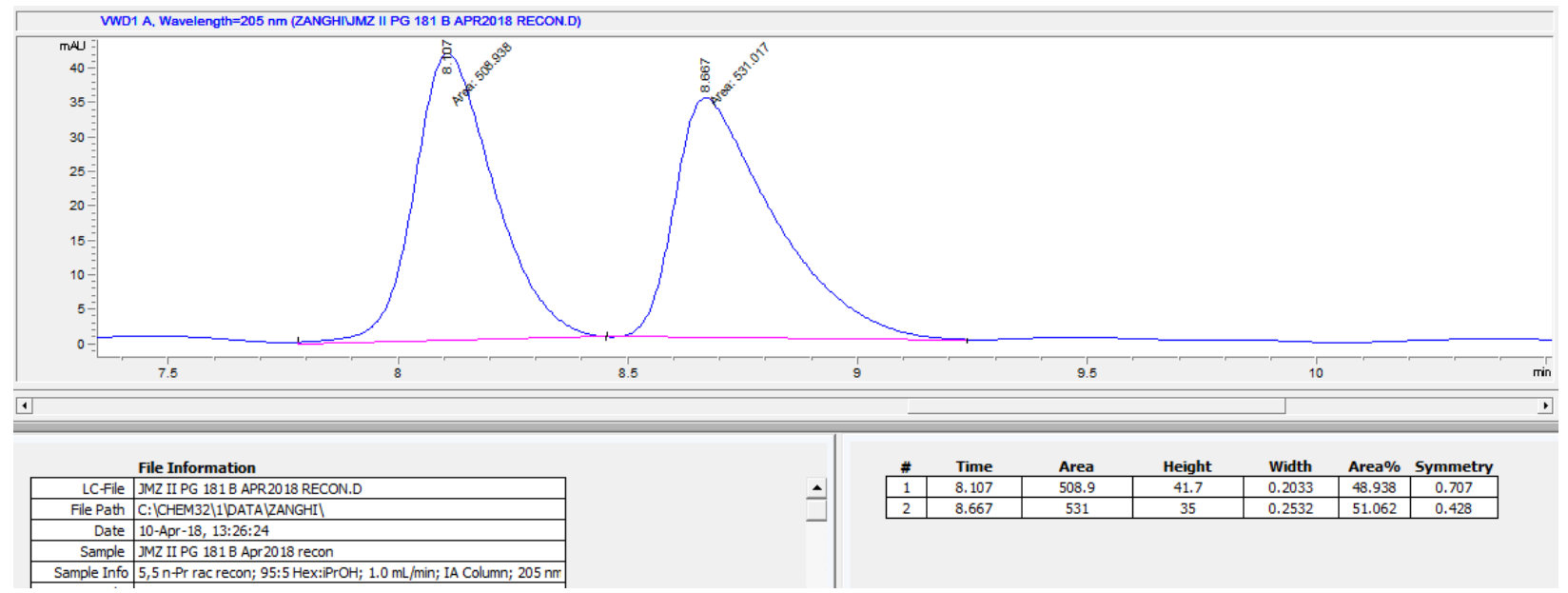

\section{Enantioenriched material:}

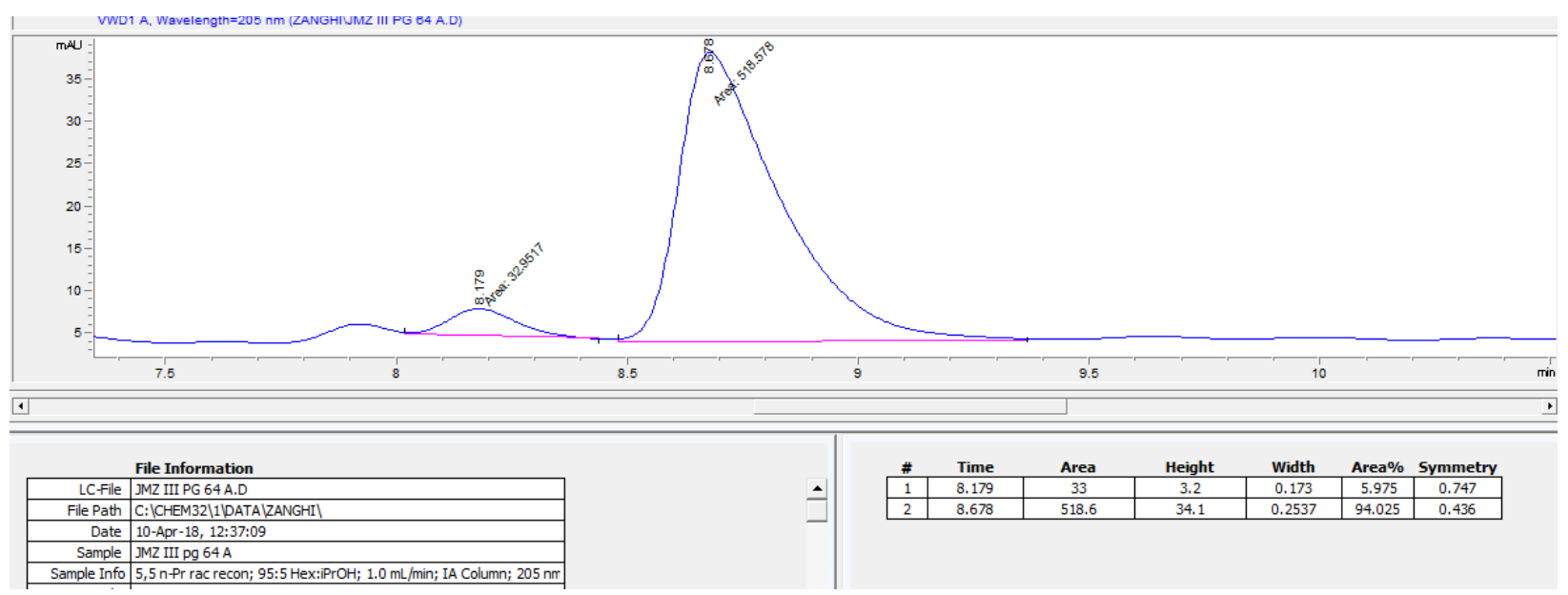

Enantioenriched material (after 1 recrystallization from hot hexanes $\rightarrow$ 97.5:2.5 er):

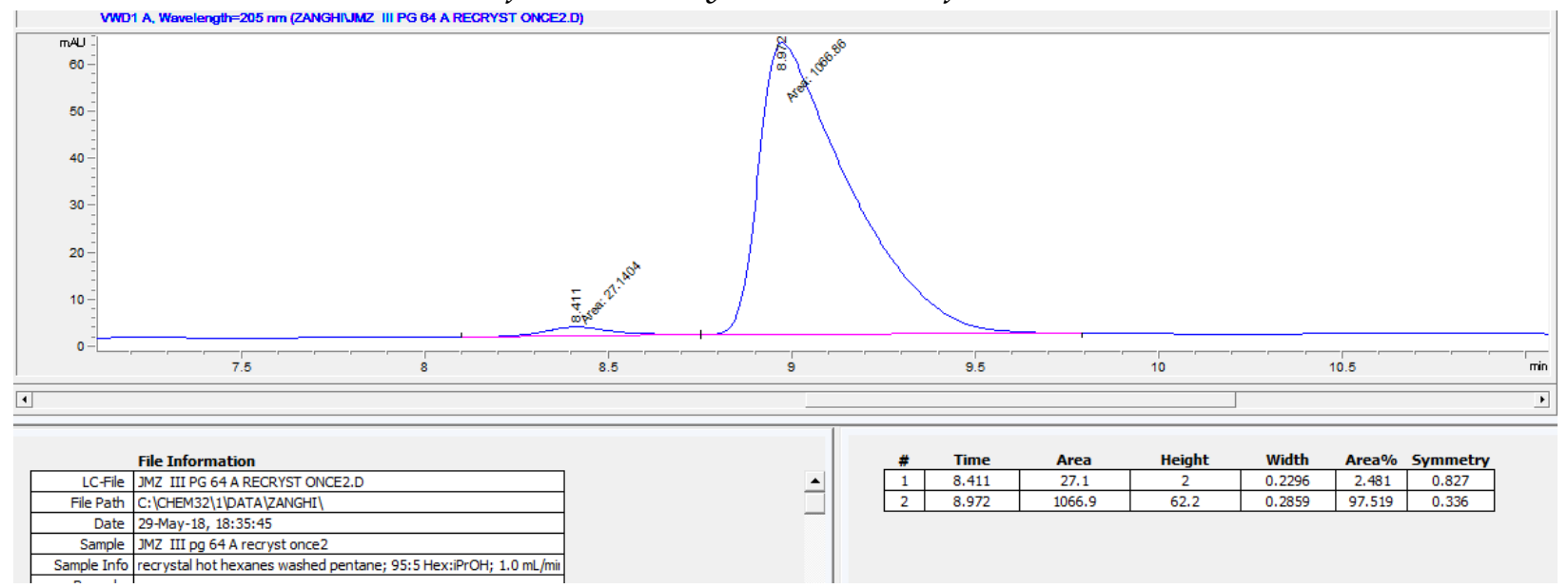


1-((1S,2S,3R,4R)-1,2-dimethyl-3,4-bis(4,4,5,5-tetramethyl-1,3,2-dioxaborolan-2-yl)-2-((4,4,5,5tetramethyl-1,3,2-dioxaborolan-2-yl)oxy)cyclopentyl)ethan-1-one (6a)

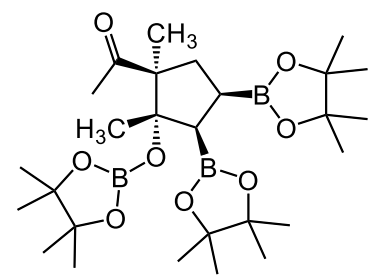

(6a)

This reaction was run using (R)-furyl-OMe-biphep. Silica gel chromatography $(100 \%$ DCM $\rightarrow$ 98.5:1.5 DCM:i-PrOH) provided tris-boronate (6a) as a clear, colorless oil (19.6 mg, 37\% yield, $>20: 1 \mathrm{dr},>99: 1 \mathrm{er})$.

${ }^{1} \mathrm{H}$ NMR (600 MHz, $\left.\mathrm{CDCl}_{3}\right): 2.52(\mathrm{~s}, 1 \mathrm{H}) ; 2.21(\mathrm{~s}, 3 \mathrm{H}) ; 2.10(\mathrm{~m}, 1 \mathrm{H}) ; 1.95(\mathrm{~m}, 1 \mathrm{H}) ; 1.57$ (m, 2H); 1.26-1.20 (m, 36H); 1.19 (s, 3H). $\left.{ }^{13} \mathrm{C} \mathrm{NMR} \mathrm{(214} \mathrm{MHz,} \mathrm{CDCl}_{3}\right):$ 213.7, 83.5, 83.3, 61.3, 33.5, 29.8, 27.3, 25.33, 25.29, 24.7, 24.6, 23.6, 19.3. HRMS (m/z): calcd for $\mathrm{C}_{21} \mathrm{H}_{37} \mathrm{~B}_{2} \mathrm{O}_{6}: 407.2782$ (M-Bpin)

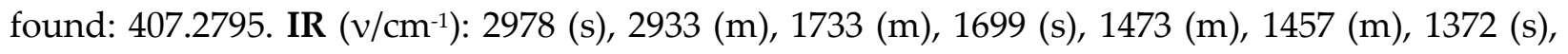
$1321(\mathrm{~s}), 1146(\mathrm{~s}), 984(\mathrm{w}), 862(\mathrm{w}), 674(\mathrm{w}) .[\alpha]_{\mathrm{D}^{23}}=-14.0^{\circ}\left(\mathrm{c}=0.92, \mathrm{CH}_{2} \mathrm{Cl}_{2}, 1=1 \mathrm{dm}\right)$.

Diacel CHIRALPAK IC Column: 98:2 hexanes:iPrOH; $1.0 \mathrm{~mL} / \mathrm{min} ; 205 \mathrm{~nm}$.

\section{Racemic material:}

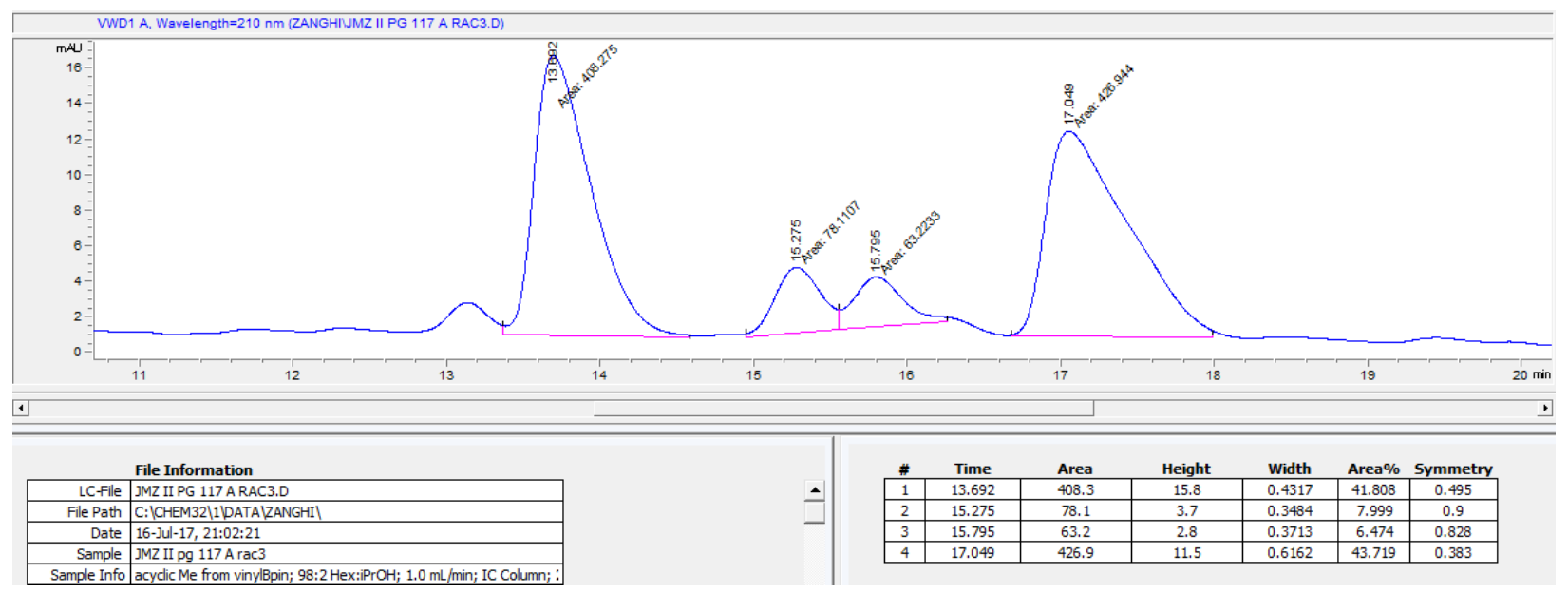




\section{Enantioenriched material:}

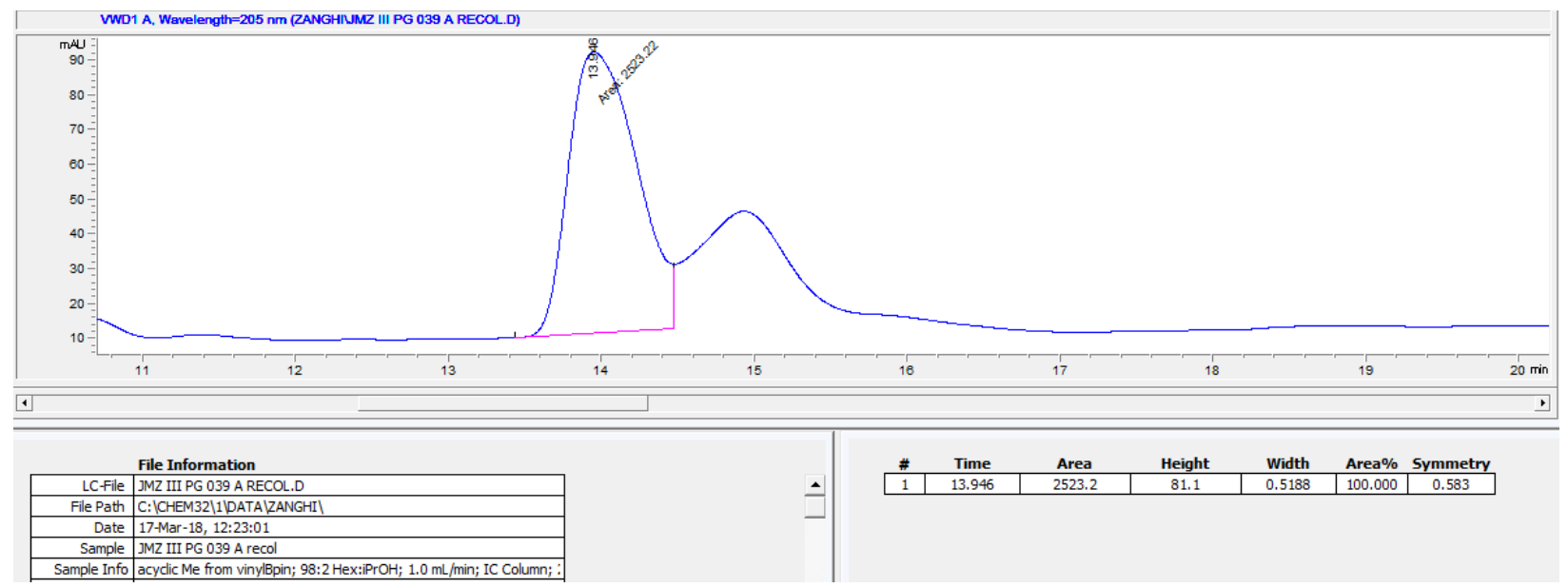

Note: Two peaks thought to result from a mixture of OBpin and free OH products, possibly in equilibrium. Peak persists after subjection to several silica gel columns. Please see vinyl boronic ester reactions for HPLC traces with a similar (but smaller) second peak. No enantiomer detected at $17 \mathrm{~min}$.

1-((1R,2R,3S,4R)-1-ethyl-2-hydroxy-2-methyl-3,4-bis(4,4,5,5-tetramethyl-1,3,2-dioxaborolan-2yl)cyclopentyl)ethan-1-one (6b)

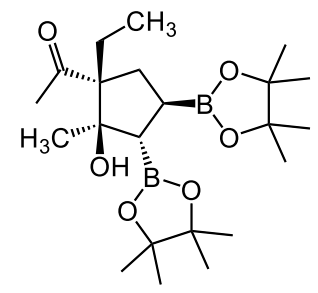

(6b)

This reaction was run using (R)-furyl-OMe-biphep. Silica gel chromatography $(15: 1 \rightarrow$ 8:1 hex:EtOAc) provided (6b) as a white solid (17.8 mg, 42\% yield, >20:1 dr, >99:1 er).

${ }^{1} \mathrm{H}$ NMR (600 MHz, $\mathrm{CDCl}_{3}$ ): 2.48 (s, 1H); 2.20 (s, 3H); 2.17-2.13 (ddd, $14.6 \mathrm{~Hz}, 7.6 \mathrm{~Hz}, 1.8 \mathrm{~Hz}$, 1H); 2.07-2.02 (ddd, 14.6 Hz, 8.9 Hz, 1.8 Hz, 1H); 1.92-1.89 (d, $12.5 \mathrm{~Hz}, 1 \mathrm{H}) ; 1.78-1.73$ (dd, 14.0 $\mathrm{Hz}, 10.4 \mathrm{~Hz}, 1 \mathrm{H}) ; 1.63$ (br s, 1H); 1.56-1.44 (m, 2H); 1.25 (s, 6H); 1.24 (s, 6H); 1.23 (s, 6H); 1.22 (s, 6H); 1.18 (s, 3H). ${ }^{13} \mathrm{C}$ NMR (151 MHz, $\left.\mathrm{CDCl}_{3}\right)$ : 213.7, 83.5, 83.3, 81.3, 66.2, 28.4, 27.8, 25.3, 25.0, 24.9, 24.7, 24.6, 24.1, 23.0, 9.0. HRMS $(\mathrm{m} / \mathrm{z})$ : calcd for $\mathrm{C}_{22} \mathrm{H}_{39} \mathrm{~B}_{2} \mathrm{O}_{6}: 421.2938\left(\mathrm{M}-\mathrm{H}^{+}\right)$; found: 421.2944. IR (v/cm-1): 2976 (s), 2359 (w), $2341(\mathrm{w}), 1698(\mathrm{~s}), 1471(\mathrm{w}), 1372(\mathrm{~s}), 1319(\mathrm{~m}), 1221(\mathrm{~m})$, $1146(\mathrm{~s}), 971(\mathrm{~m}), 860(\mathrm{~m}) .[\alpha]_{\mathrm{D}^{23}}=-13.4^{\circ}\left(\mathrm{c}=0.92, \mathrm{CH}_{2} \mathrm{Cl}_{2}, 1=1 \mathrm{dm}\right)$. 
Diacel CHIRALPAK IC Column: 97:3 hexanes:iPrOH; 1.0 mL/min; 205 nm.

Racemic material:

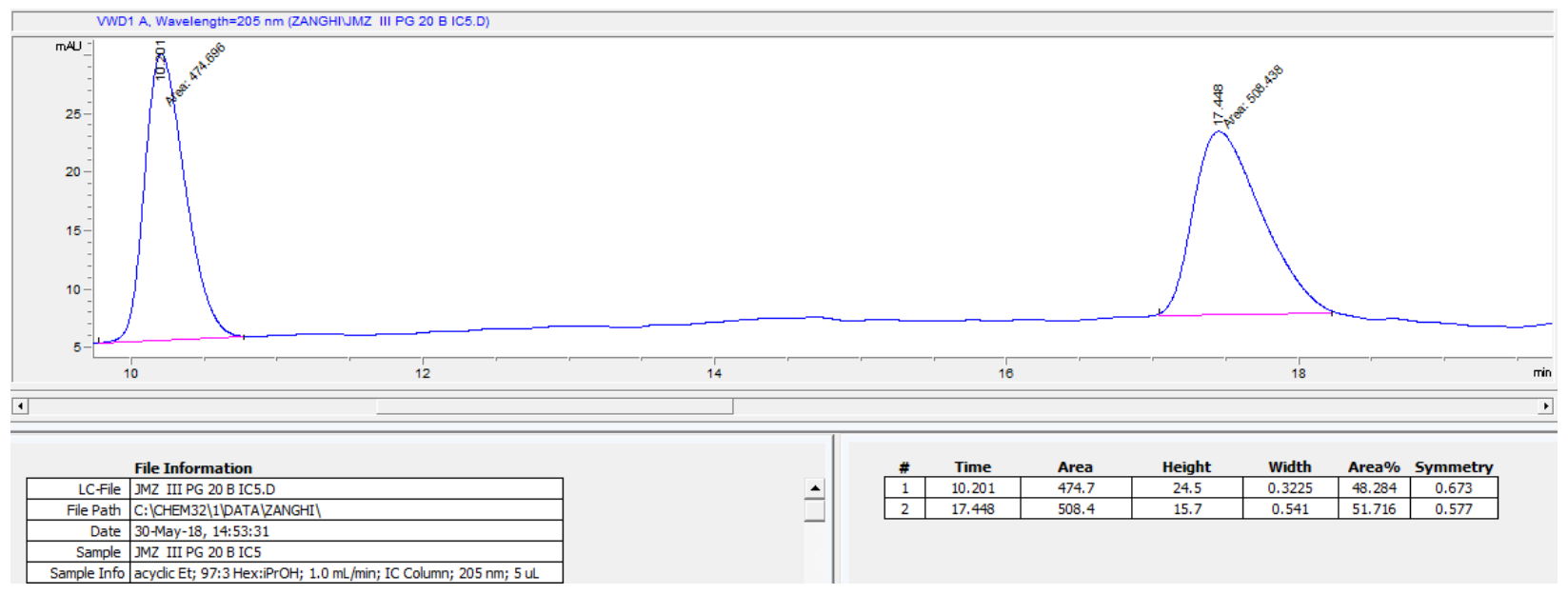

Enantioenriched material:

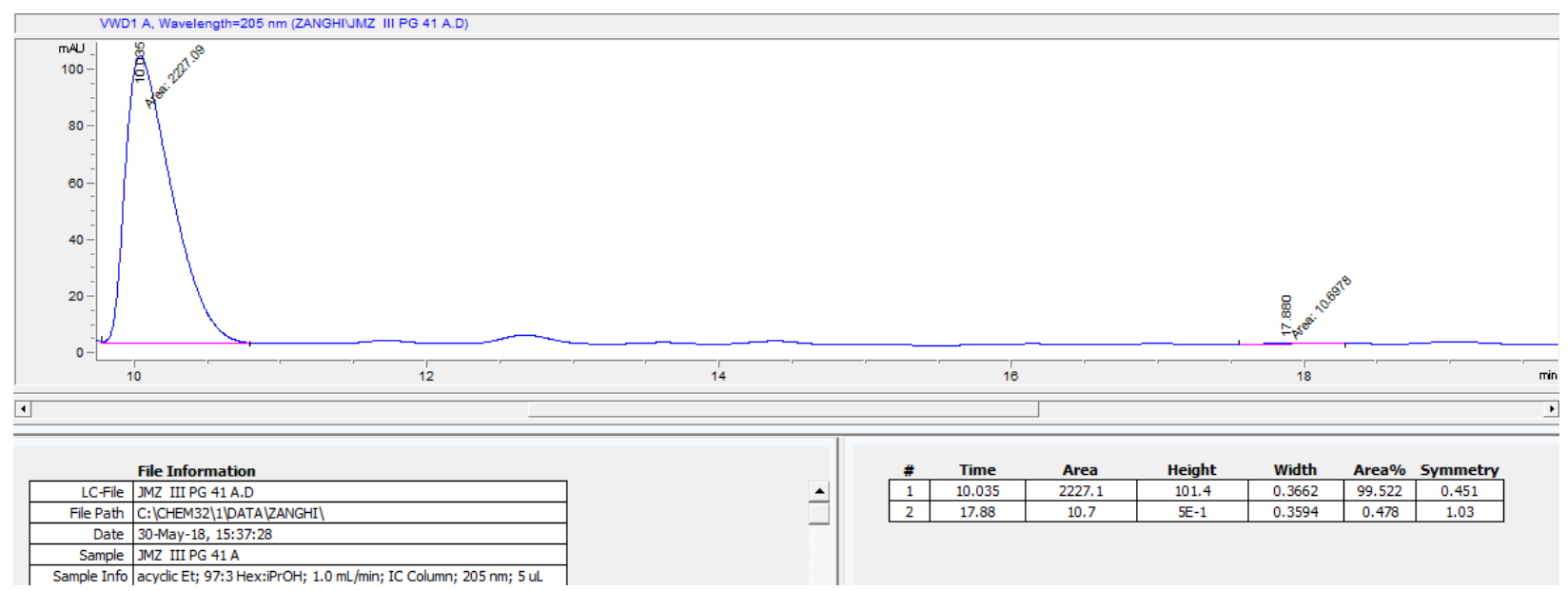




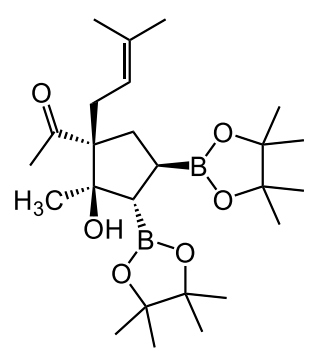

(6c)

This reaction was run using (R)-furyl-OMe-biphep. Silica gel chromatography $(100 \%$ DCM $\rightarrow$ 99:1 DCM:i-PrOH) provided (6c) as a clear, colorless oil (22.2 mg, 48\% yield, 17:1 dr, >99:1 er).

${ }^{1} \mathrm{H}$ NMR (400 MHz, $\mathrm{CDCl}_{3}$ ): 4.82 (maj. diast., t, $7.6 \mathrm{~Hz}, 1 \mathrm{H}$ ); 4.77 (min. diast., t, $7.6 \mathrm{~Hz}, 0.06 \mathrm{H}$ ); 2.79-2.74 (dd, 14.7 Hz, 6.6 Hz, 1H); $2.53(\mathrm{~s}, 1 \mathrm{H}) ; 2.26-2.16(\mathrm{~m}, 1 \mathrm{H}) ; 2.18(\mathrm{~s}, 3 \mathrm{H}) ; 2.11-1.95(\mathrm{~m}, 3 \mathrm{H})$; $1.75-1.67$ (m, 2H); $1.64(\mathrm{~s}, 3 \mathrm{H}) ; 1.60(\mathrm{~s}, 3 \mathrm{H}) ; 1.58-1.52(\mathrm{~m}, 1 \mathrm{H}) ; 1.25-1.20(\mathrm{~m}, 24 \mathrm{H}) ; 1.18(\mathrm{~s}, 3 \mathrm{H}) .{ }^{13} \mathrm{C}$ NMR (214 MHz, $\left.\mathrm{CDCl}_{3}\right):$ 213.5, 134.8, 119.7, 83.5, 83.3, 81.4, 65.8, 55.2, 29.6, 29.5, 28.0, 26.1, 25.3, 24.9, 24.7, 24.6, 24.1, 18.2. HRMS (m/z): calcd for $\mathrm{C}_{25} \mathrm{H}_{43} \mathrm{~B}_{2} \mathrm{O}_{6}: 461.3251\left(\mathrm{M}-\mathrm{H}^{+}\right)$; found: 461.3262. IR (v/cm-1): $2978(\mathrm{~s}), 2929(\mathrm{~m}), 2360(\mathrm{w}), 2341(\mathrm{w}), 1698(\mathrm{~s}), 1407$ (m), 1372 (s), 1319 (s), $1216(\mathrm{~m})$, $1146(\mathrm{~s}), 971(\mathrm{~m}), 854(\mathrm{~m}) .[\alpha]_{\mathrm{D}^{23}}=-12.0^{\circ}\left(\mathrm{c}=1.02, \mathrm{CH}_{2} \mathrm{Cl}_{2}, \mathrm{l}=1 \mathrm{dm}\right)$.

Phenomenex Lux Amylose-1 AD Column: 98:2 CO2:iPrOH; $1.0 \mathrm{~mL} / \mathrm{min} ; 210 \mathrm{~nm}$.

\section{Racemic material:}

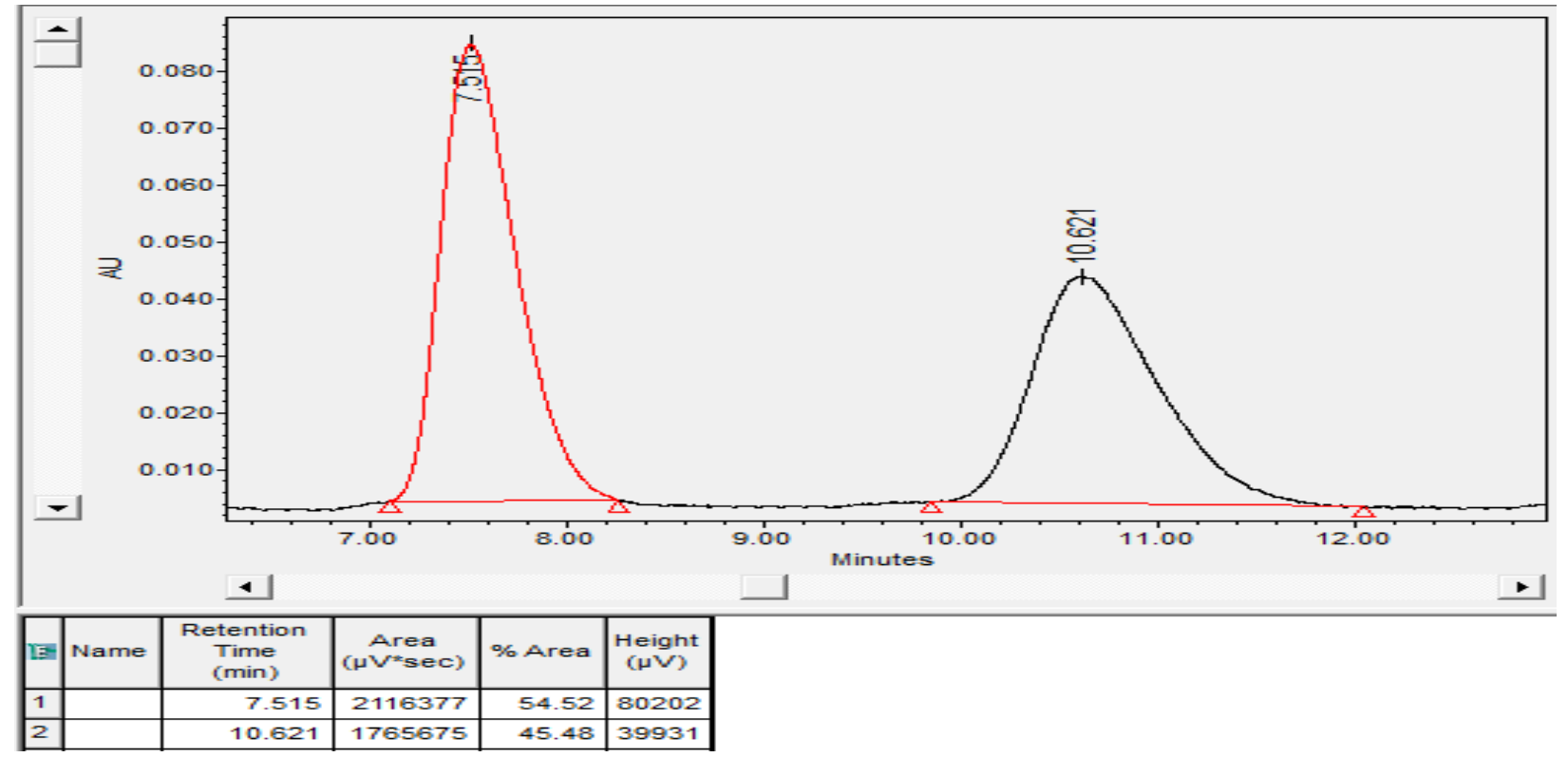


Enantioenriched material:

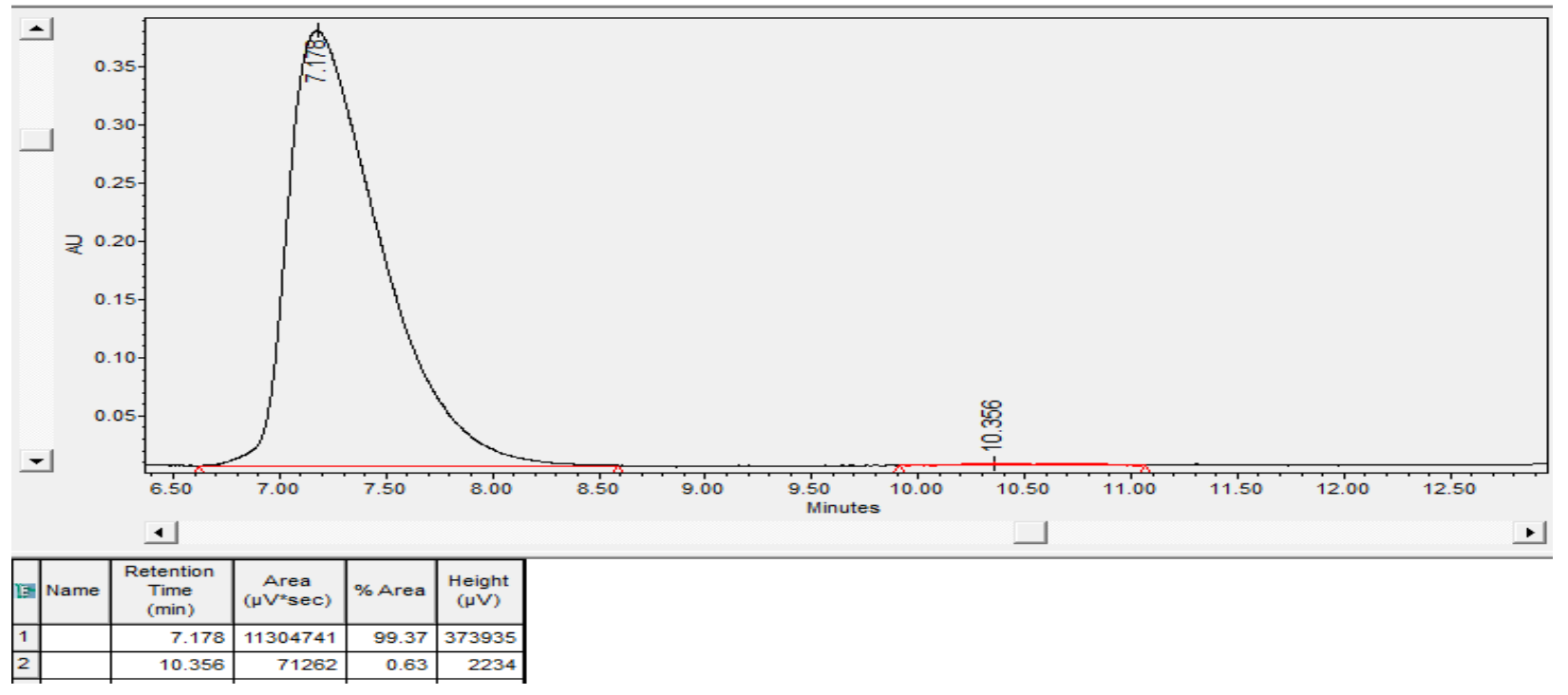




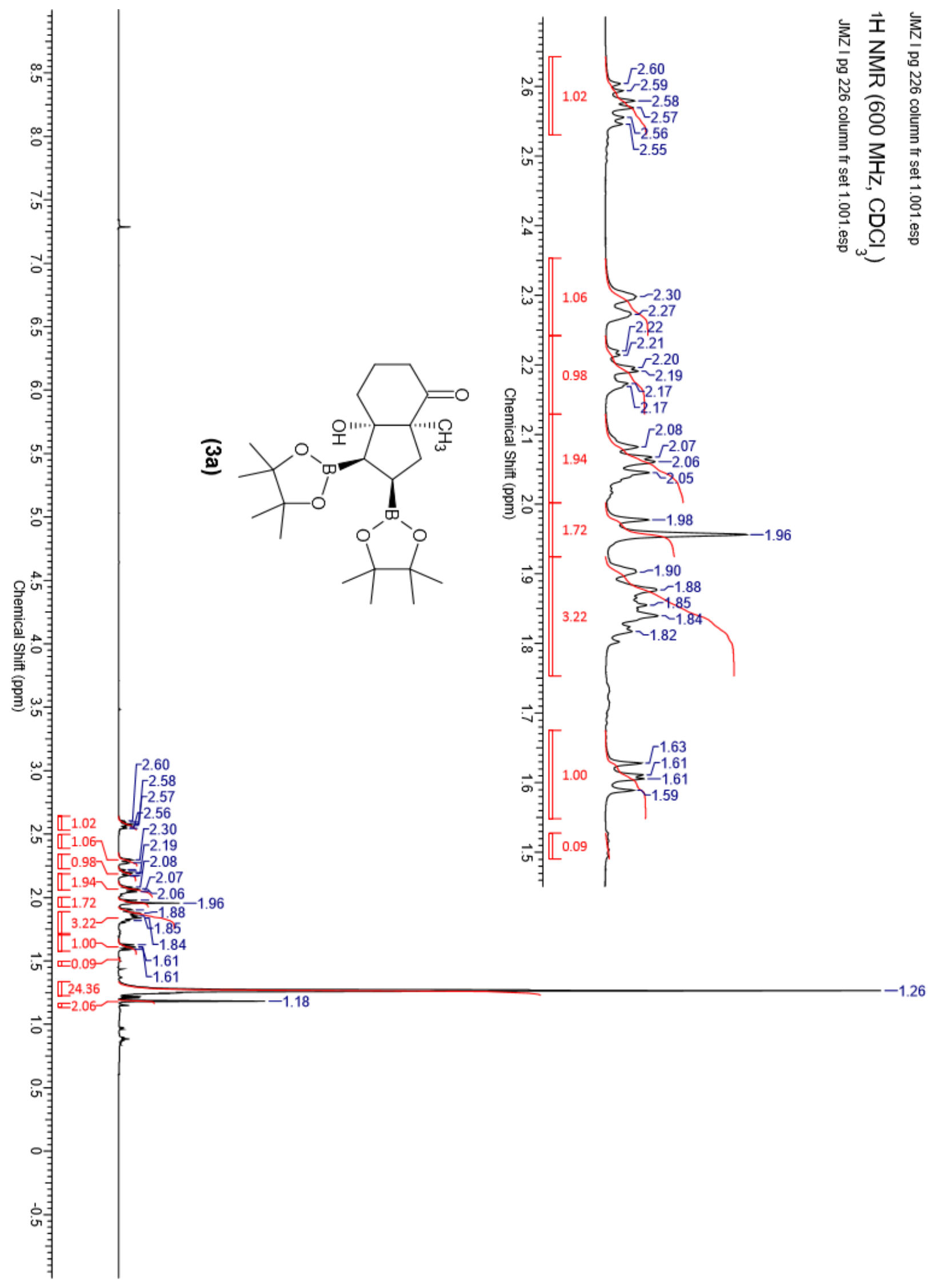




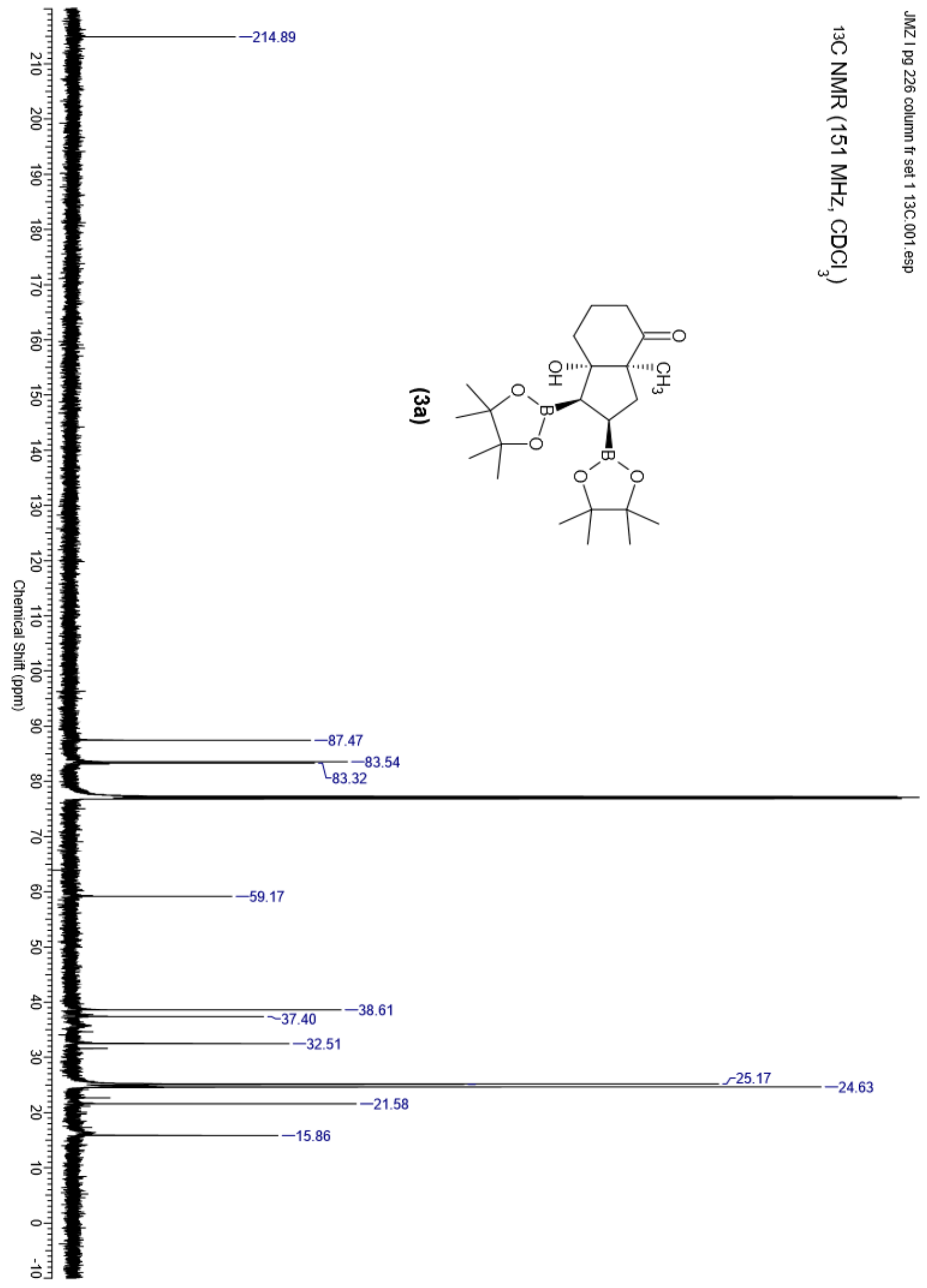




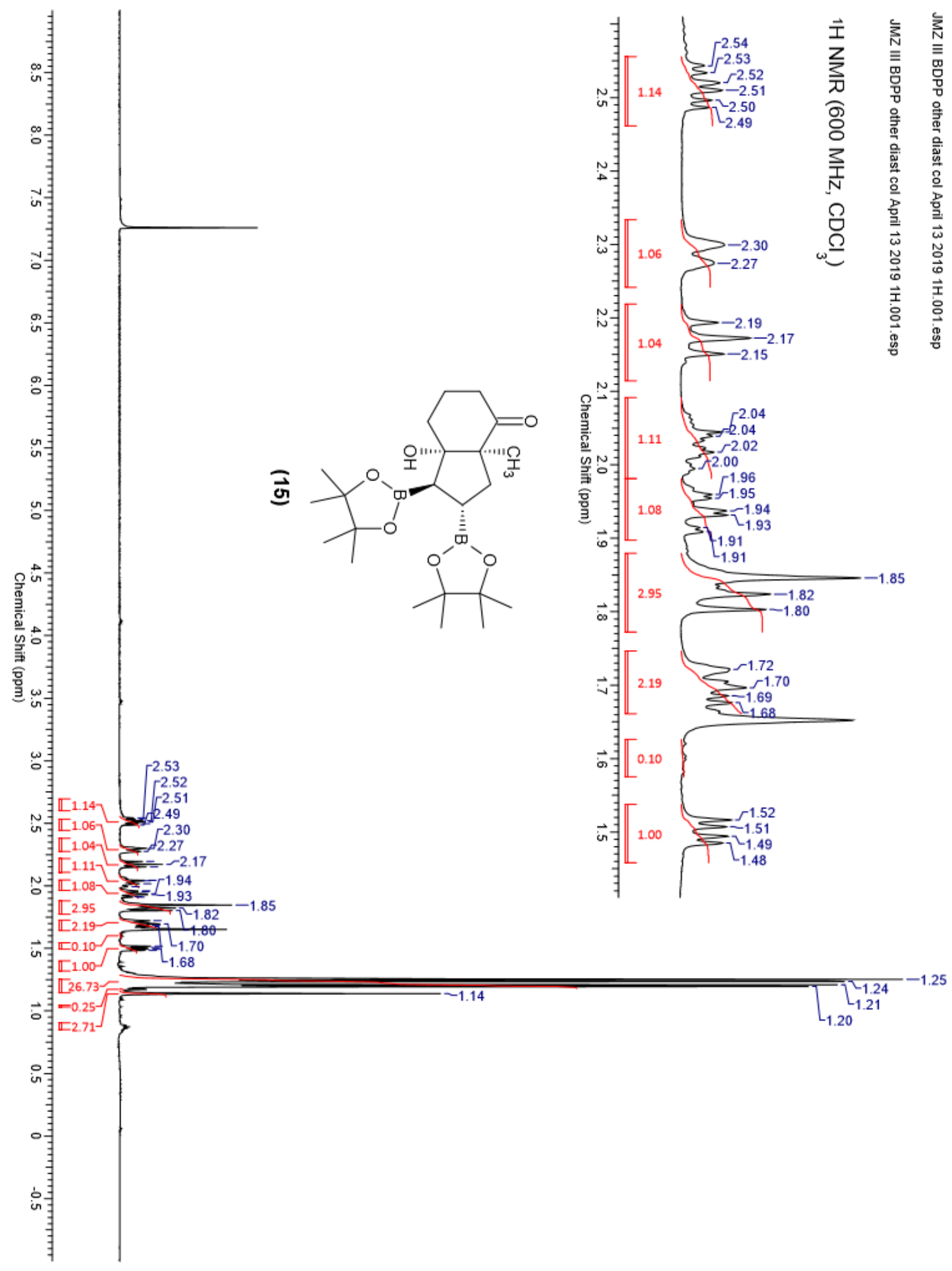




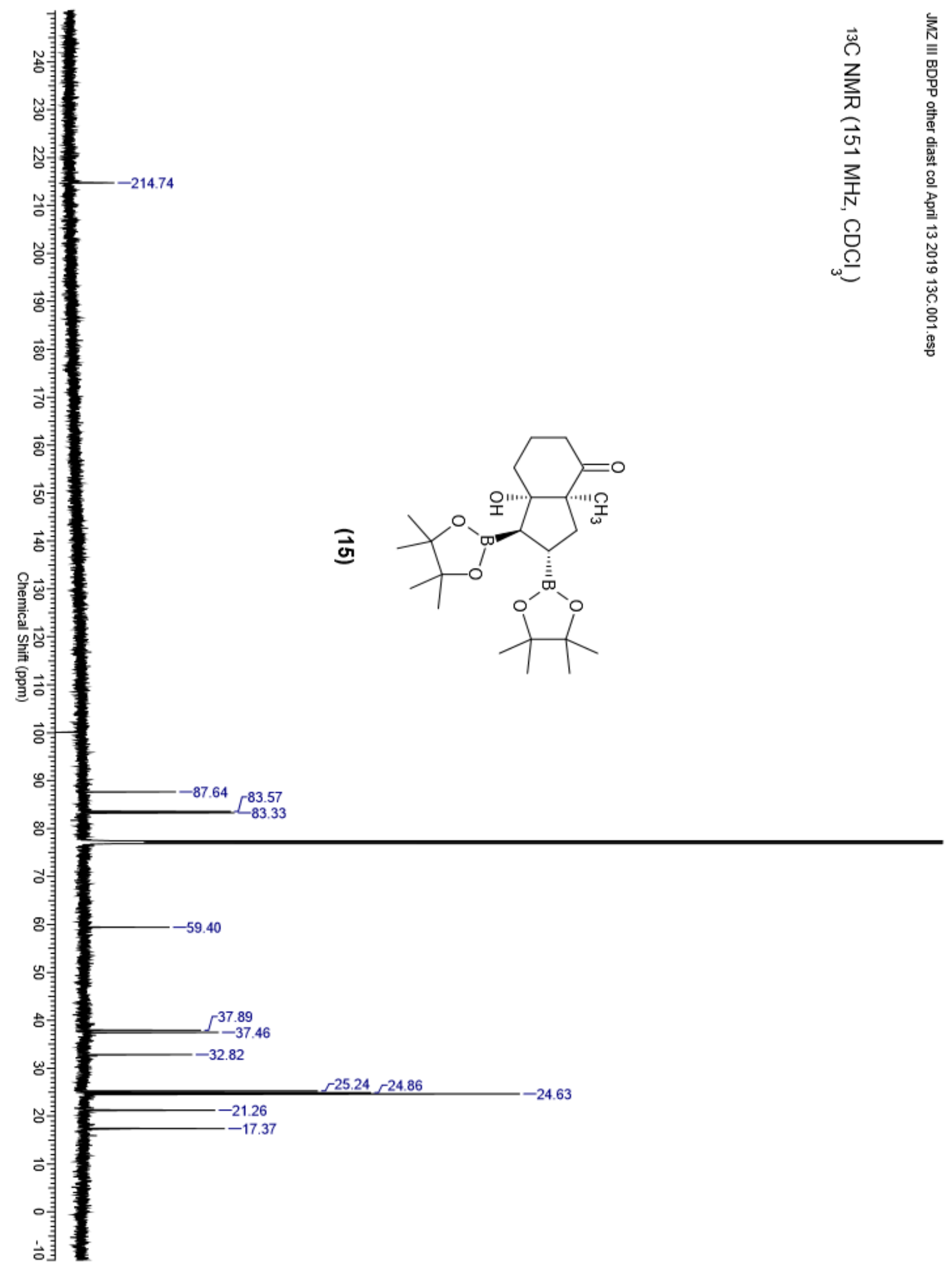




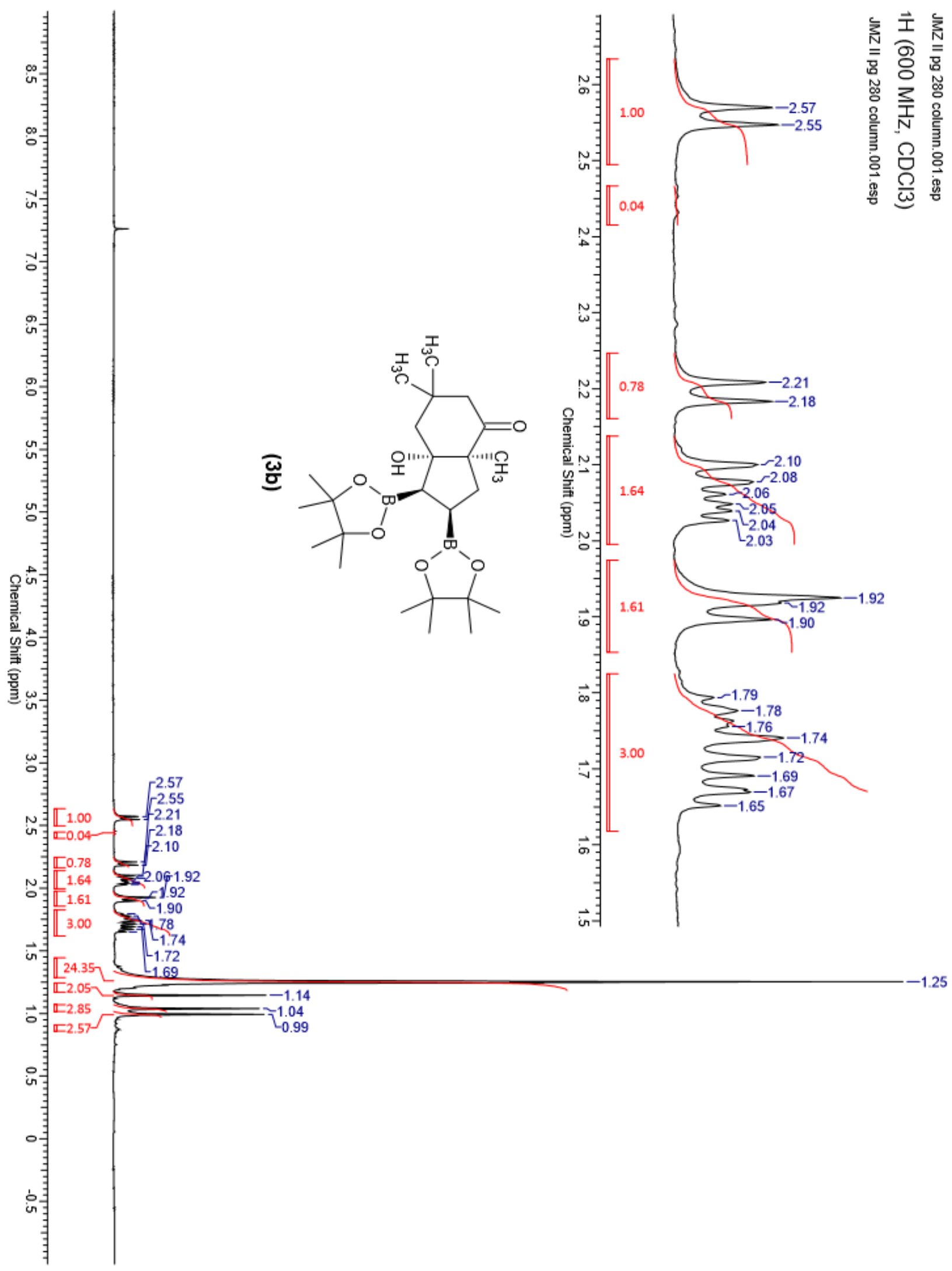




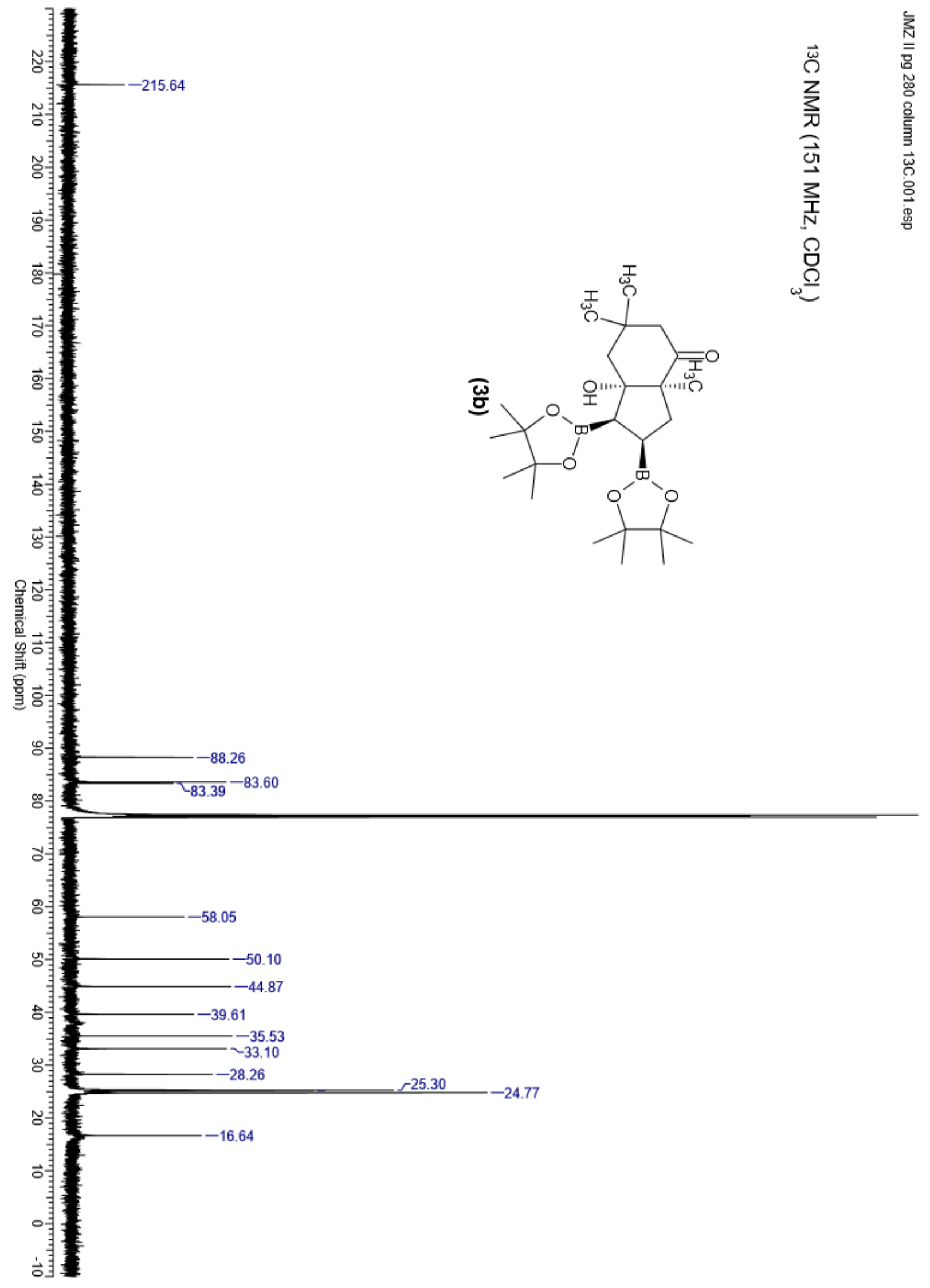




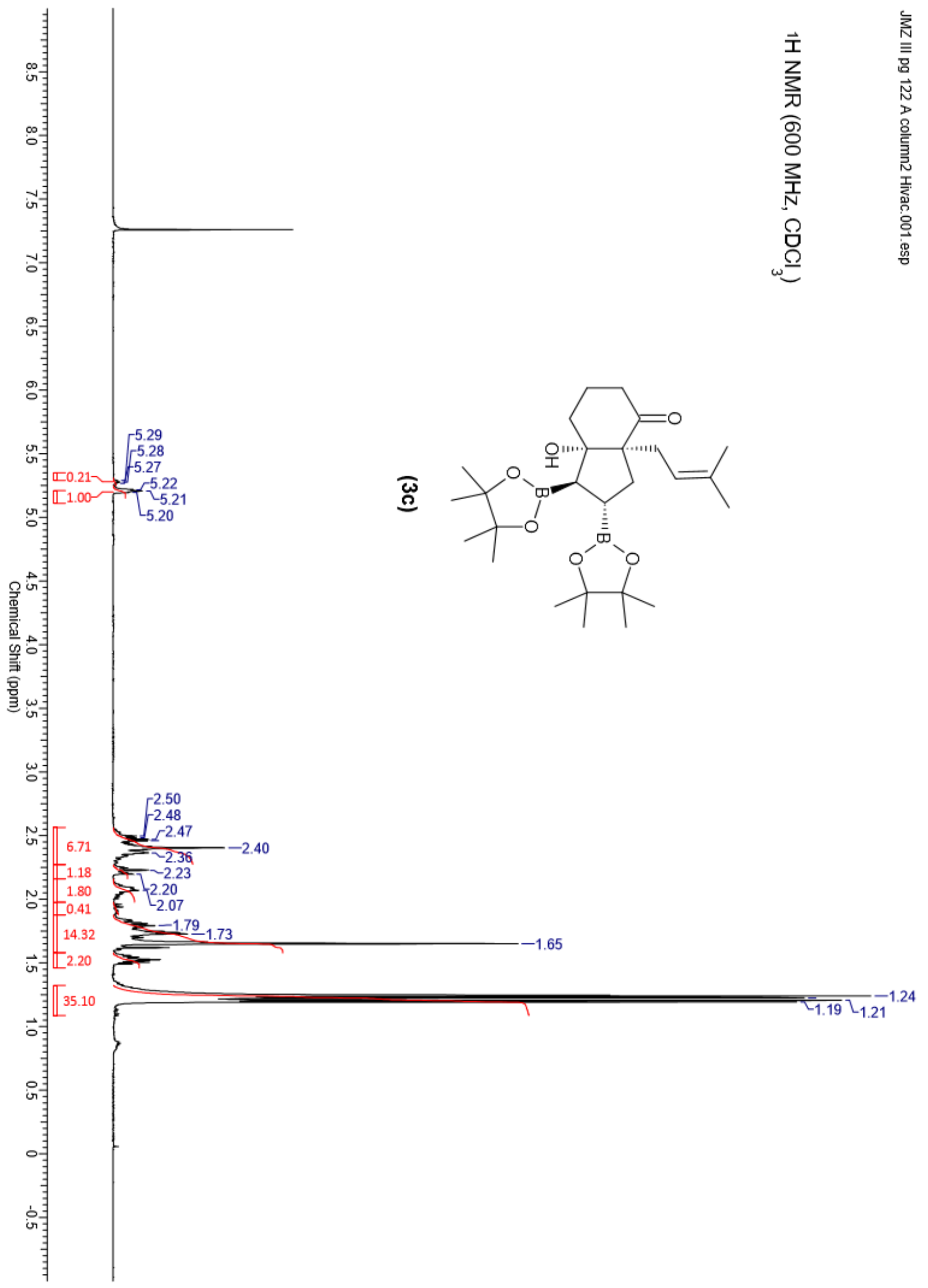




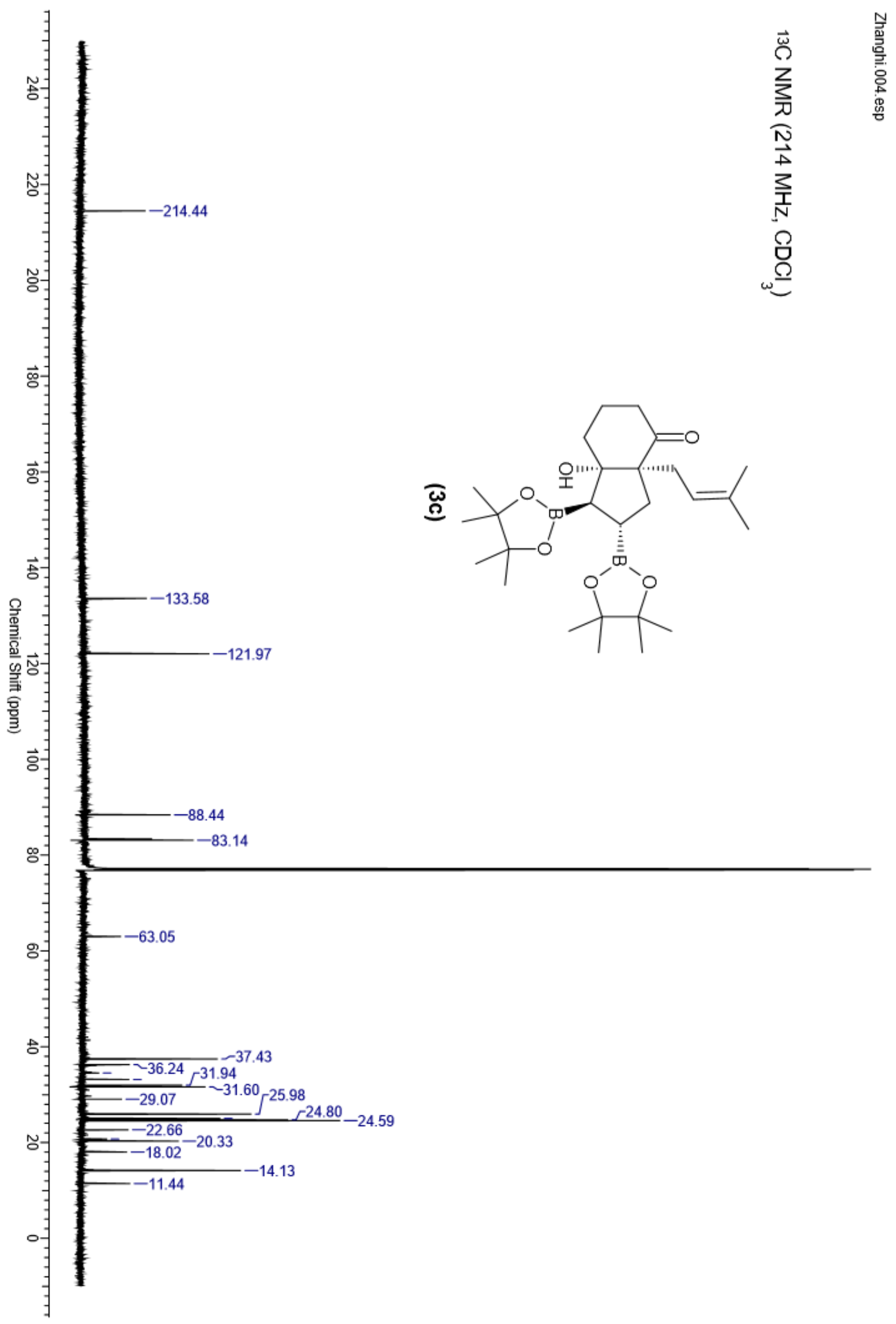




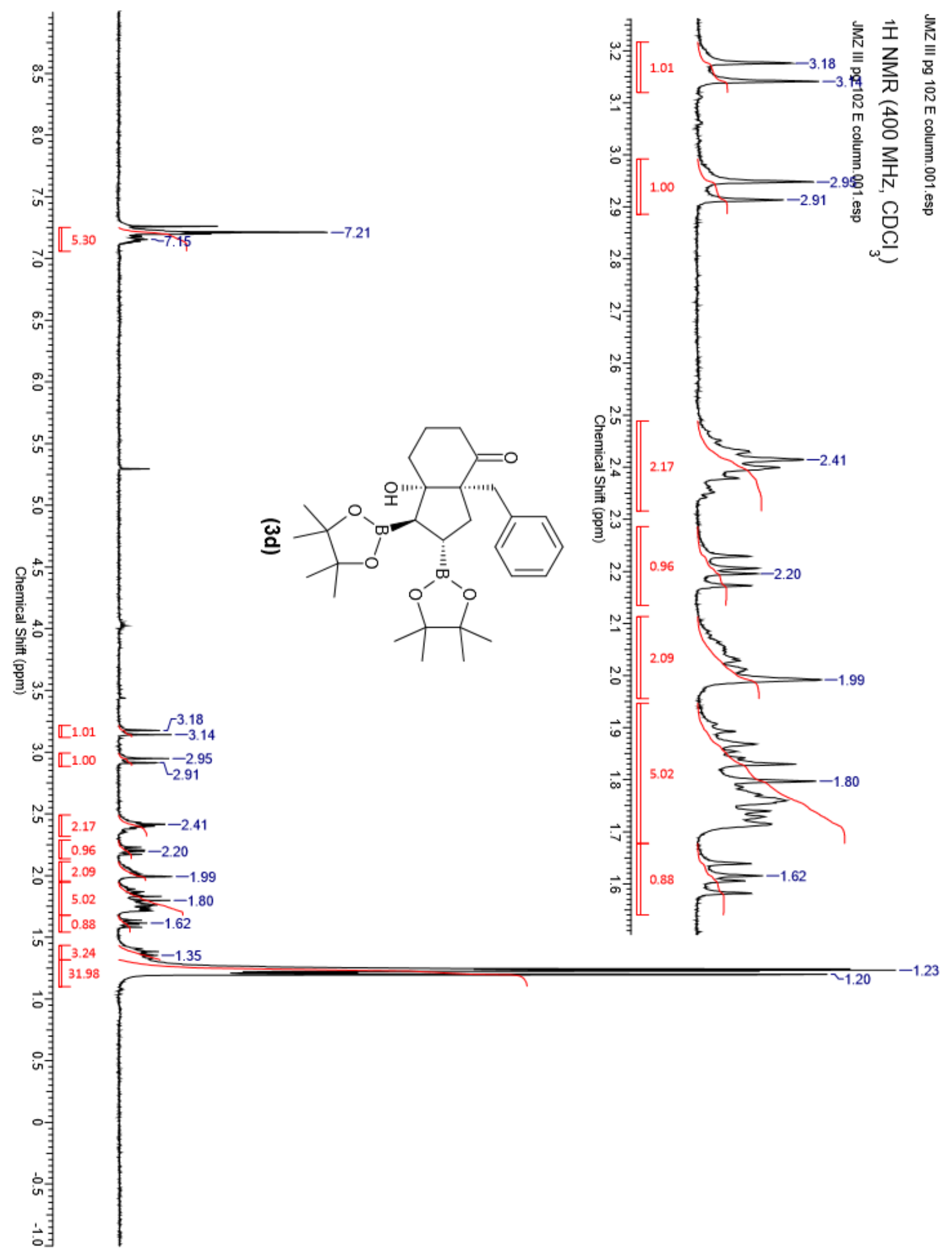




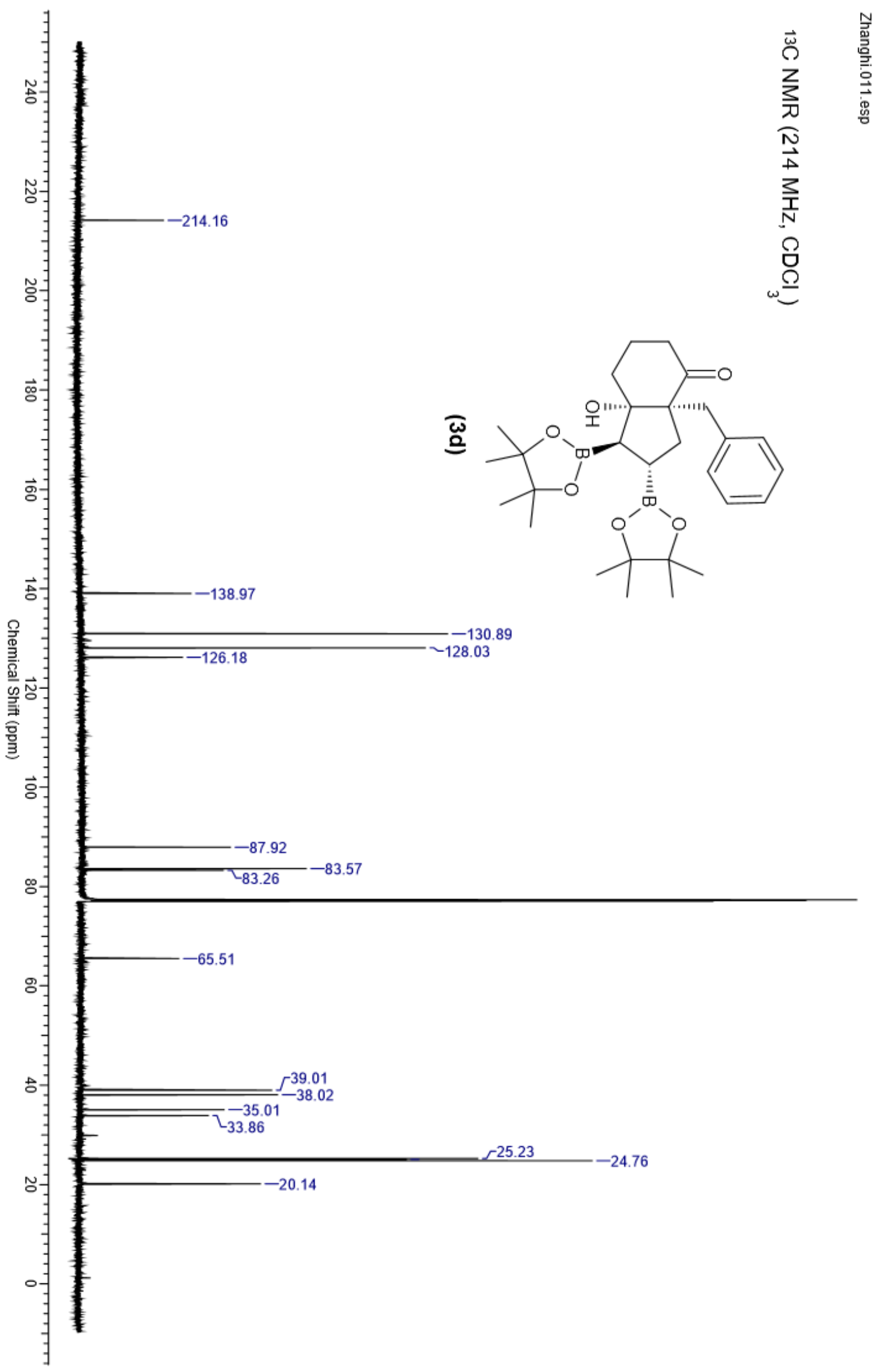




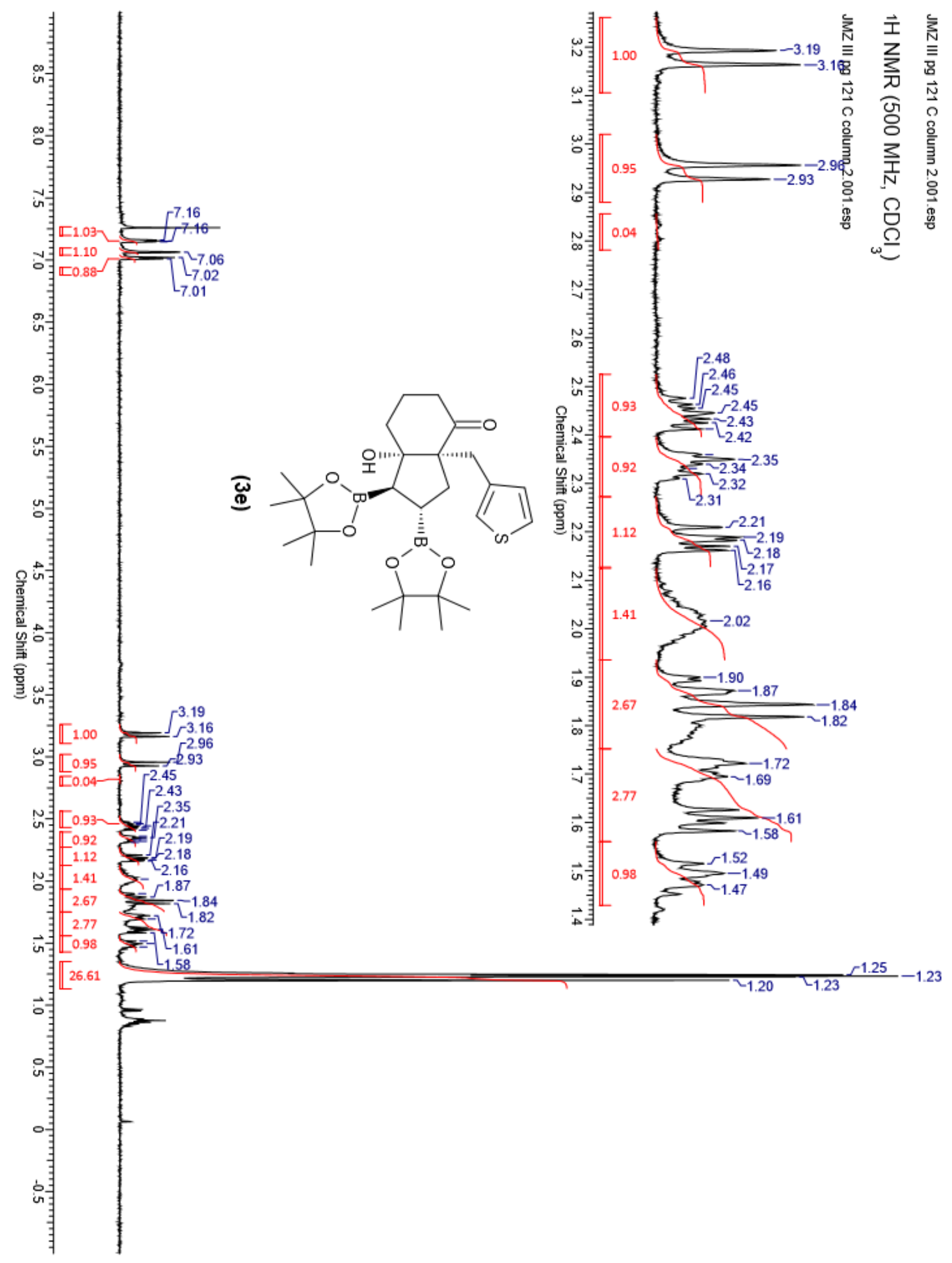




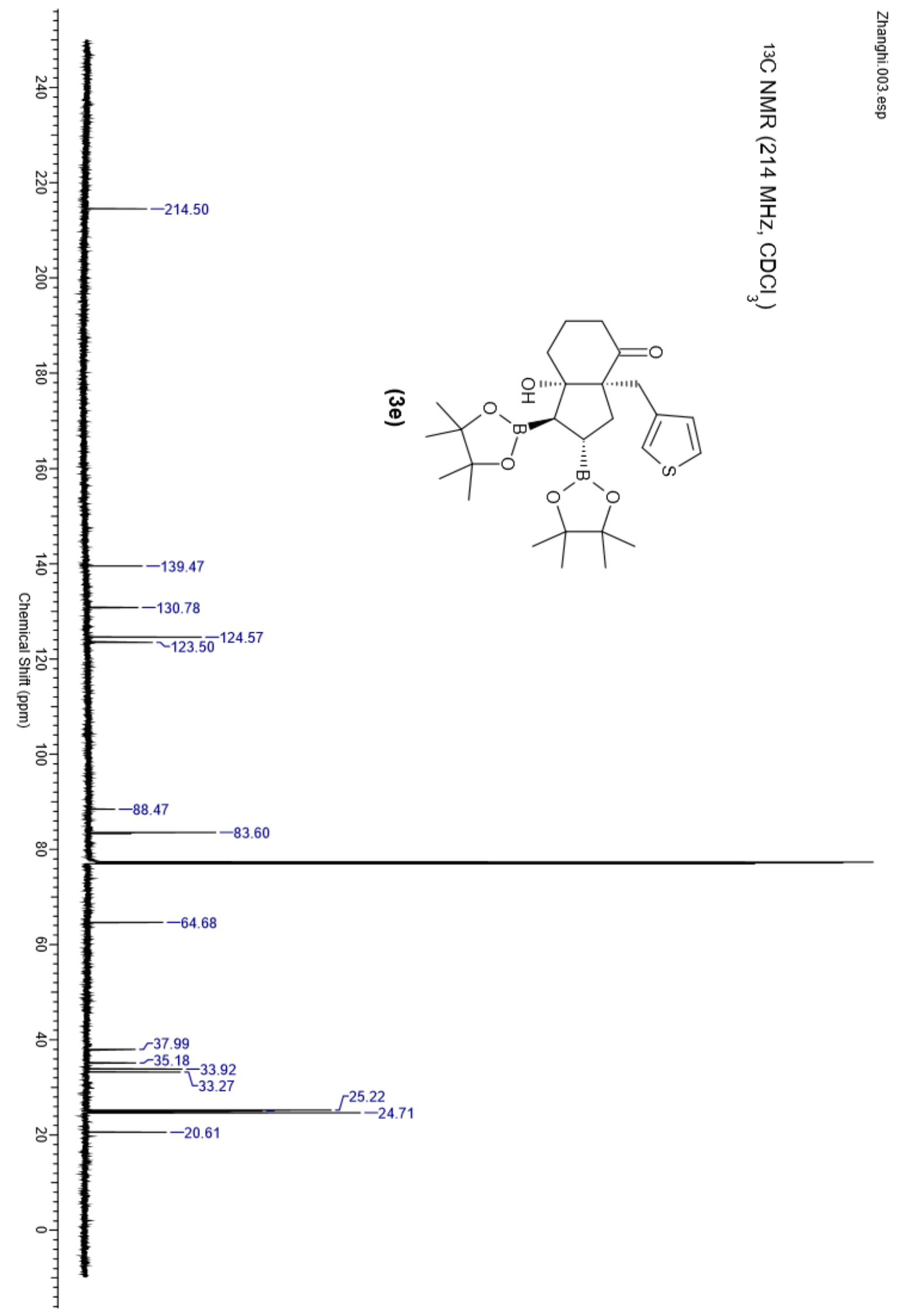




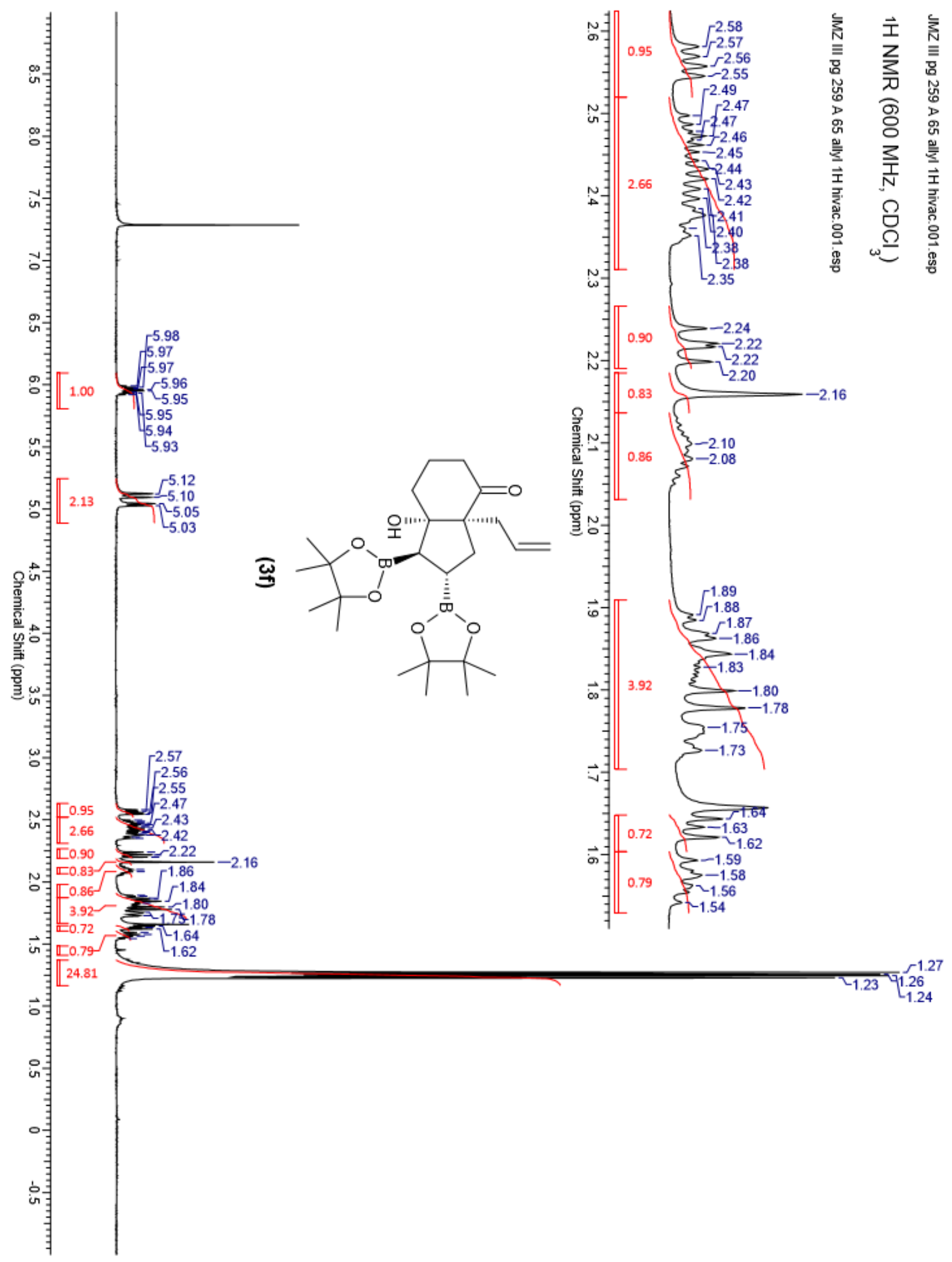




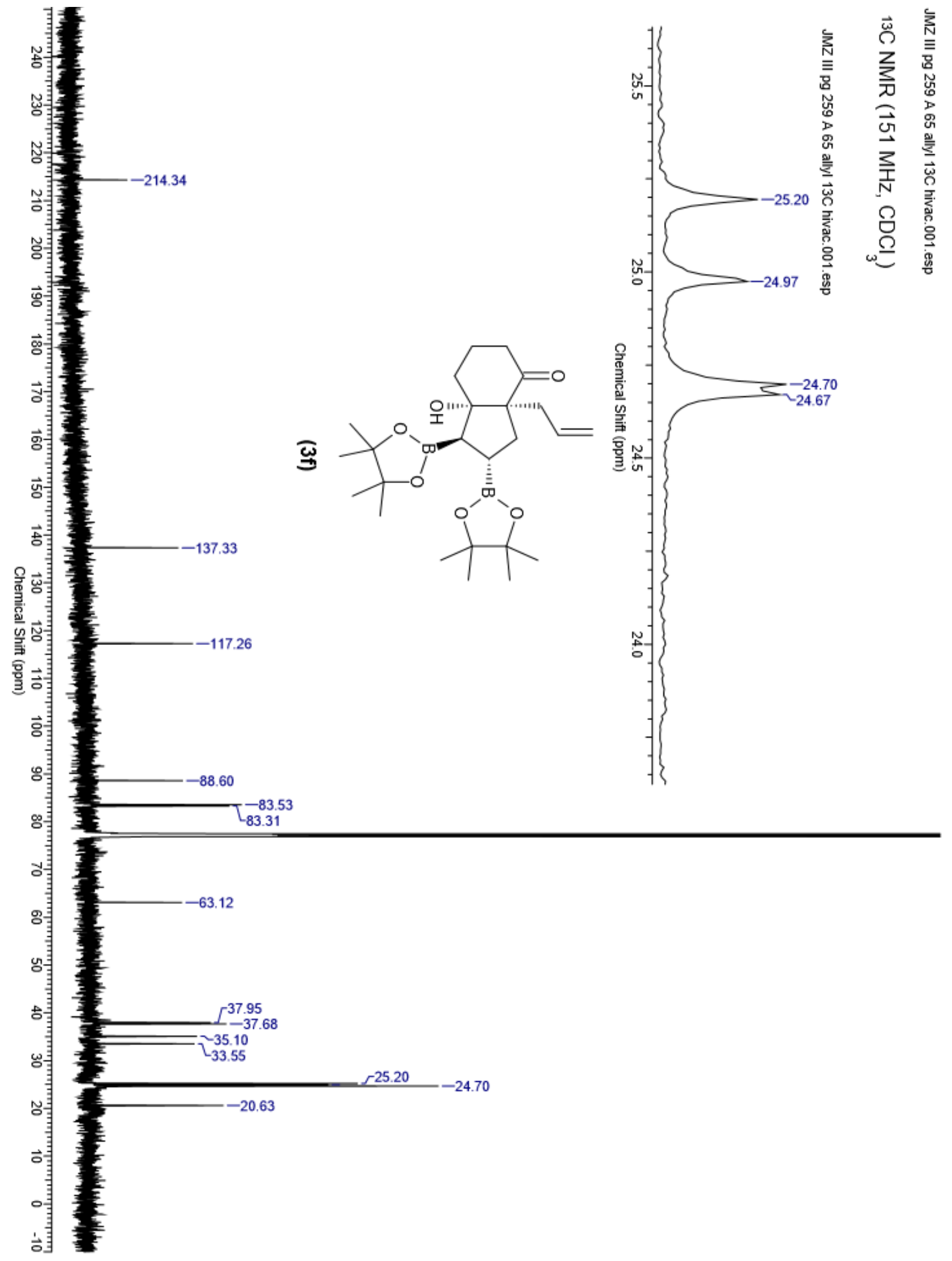




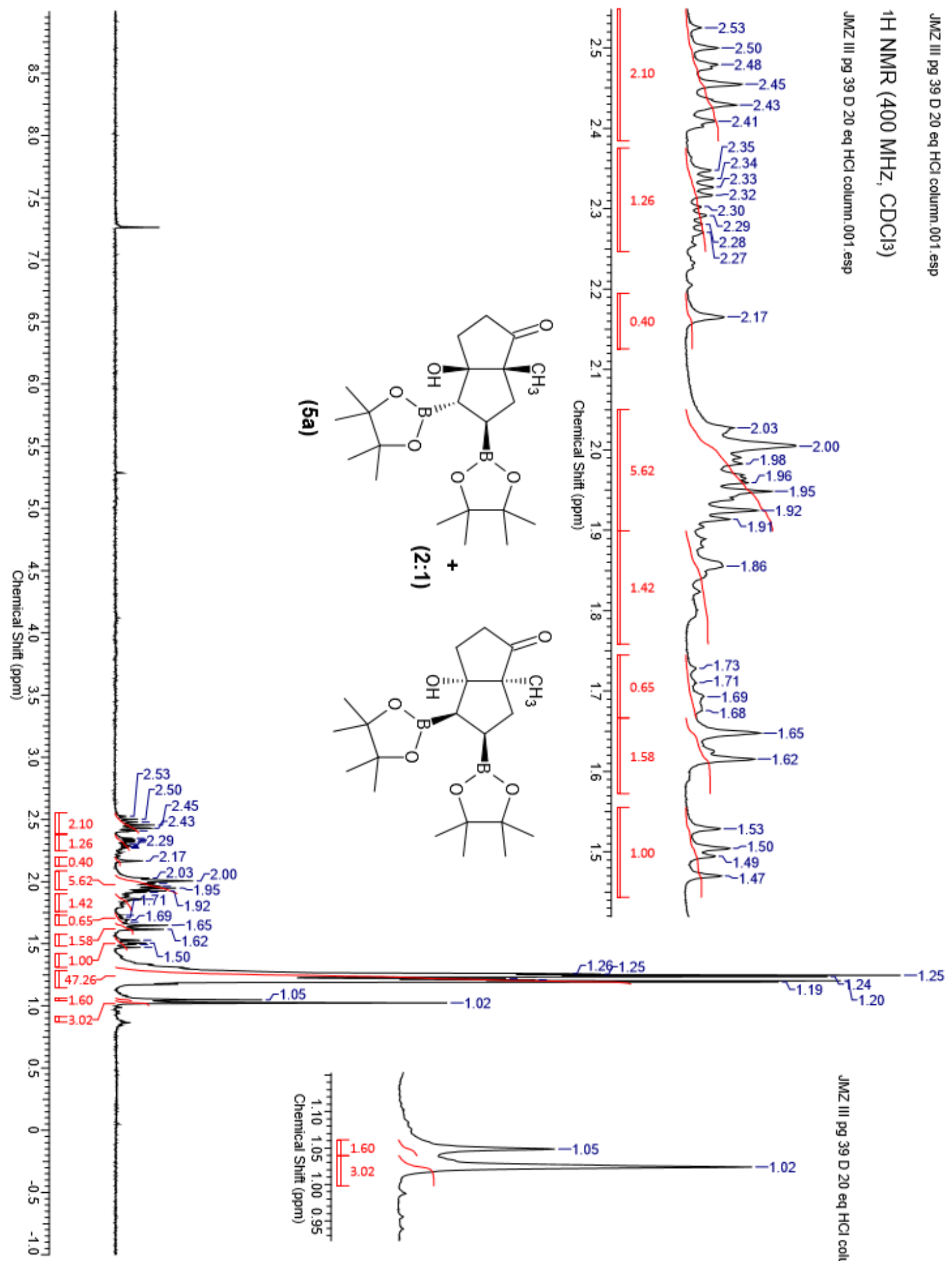




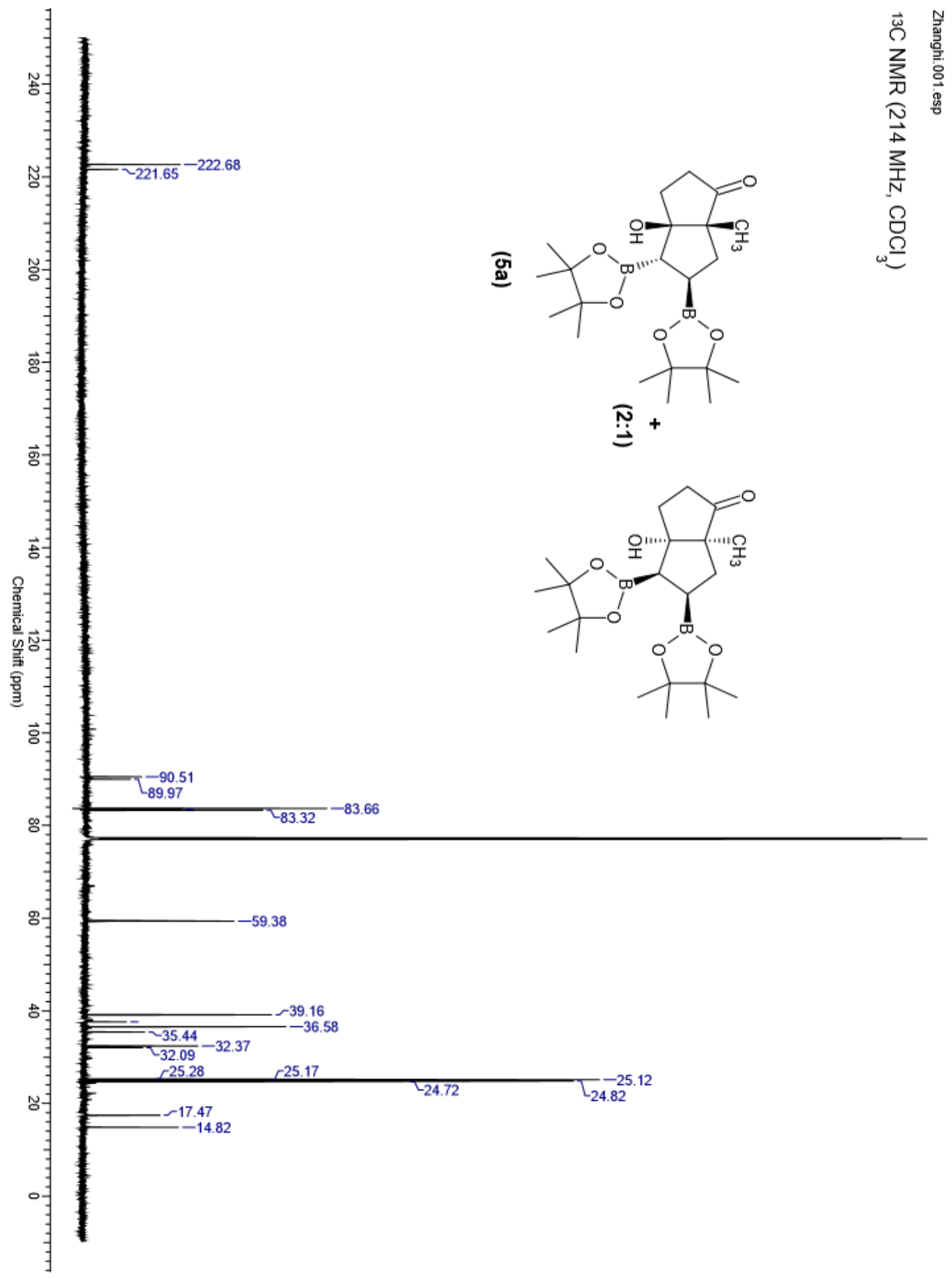




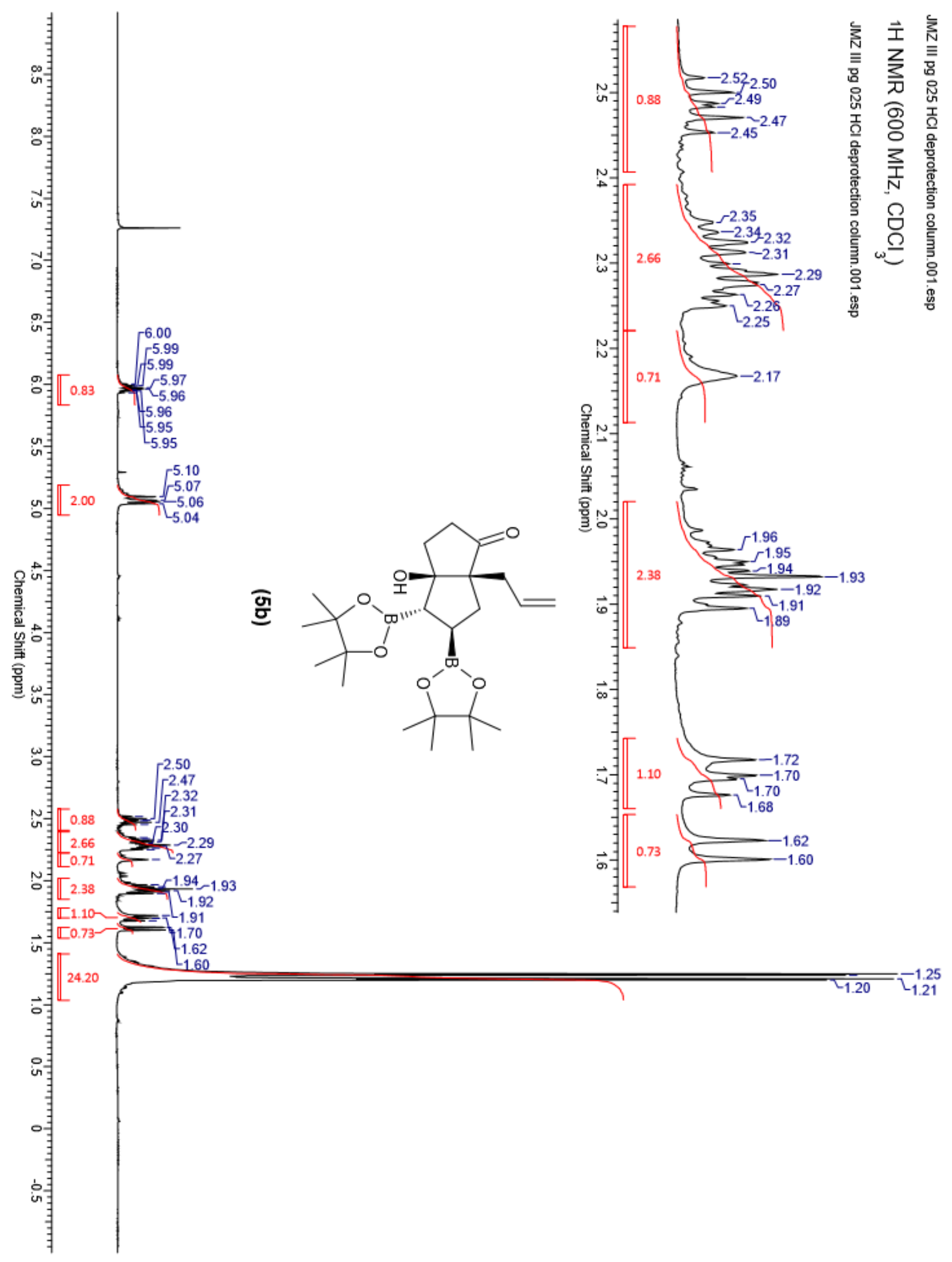




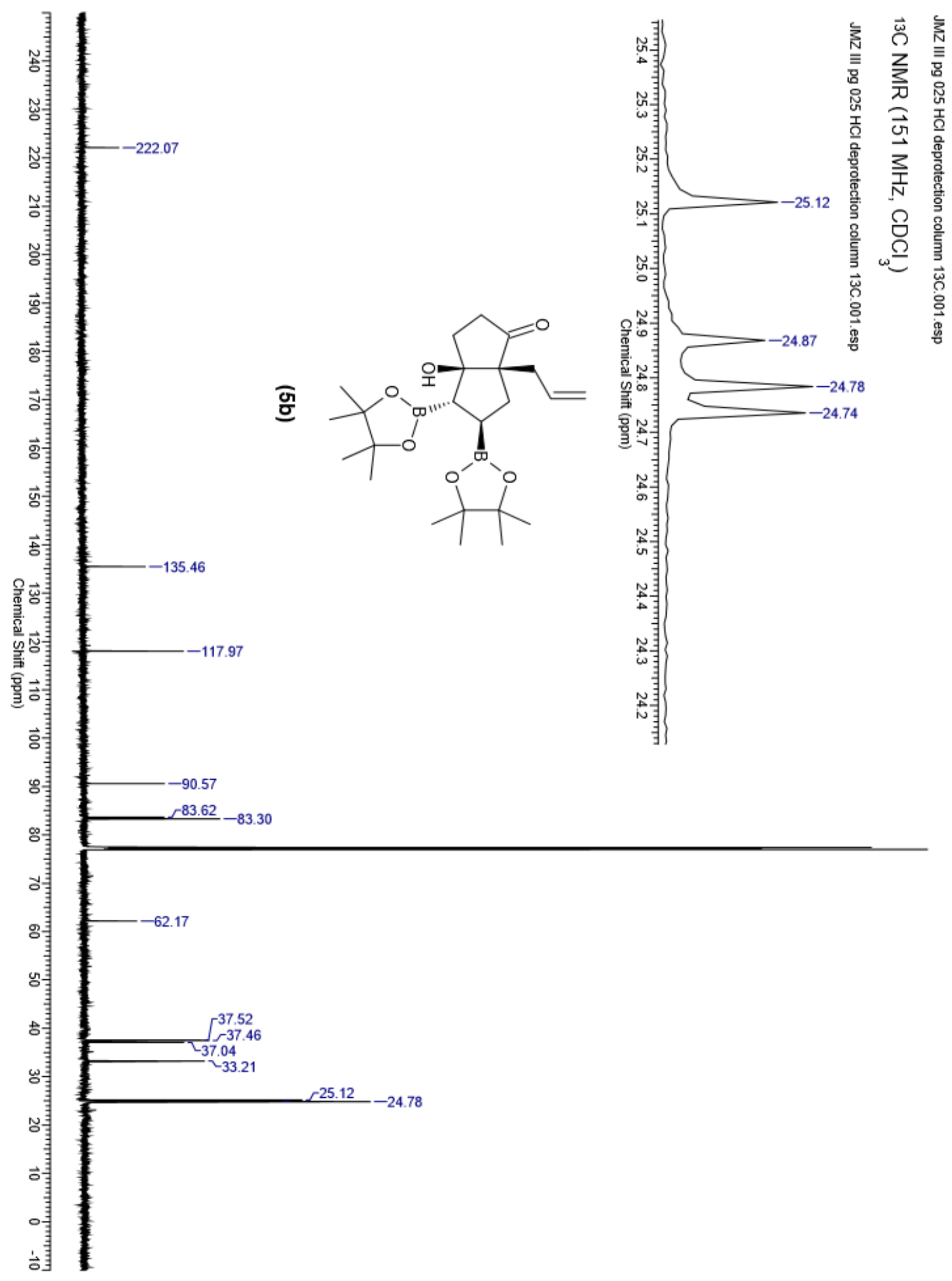




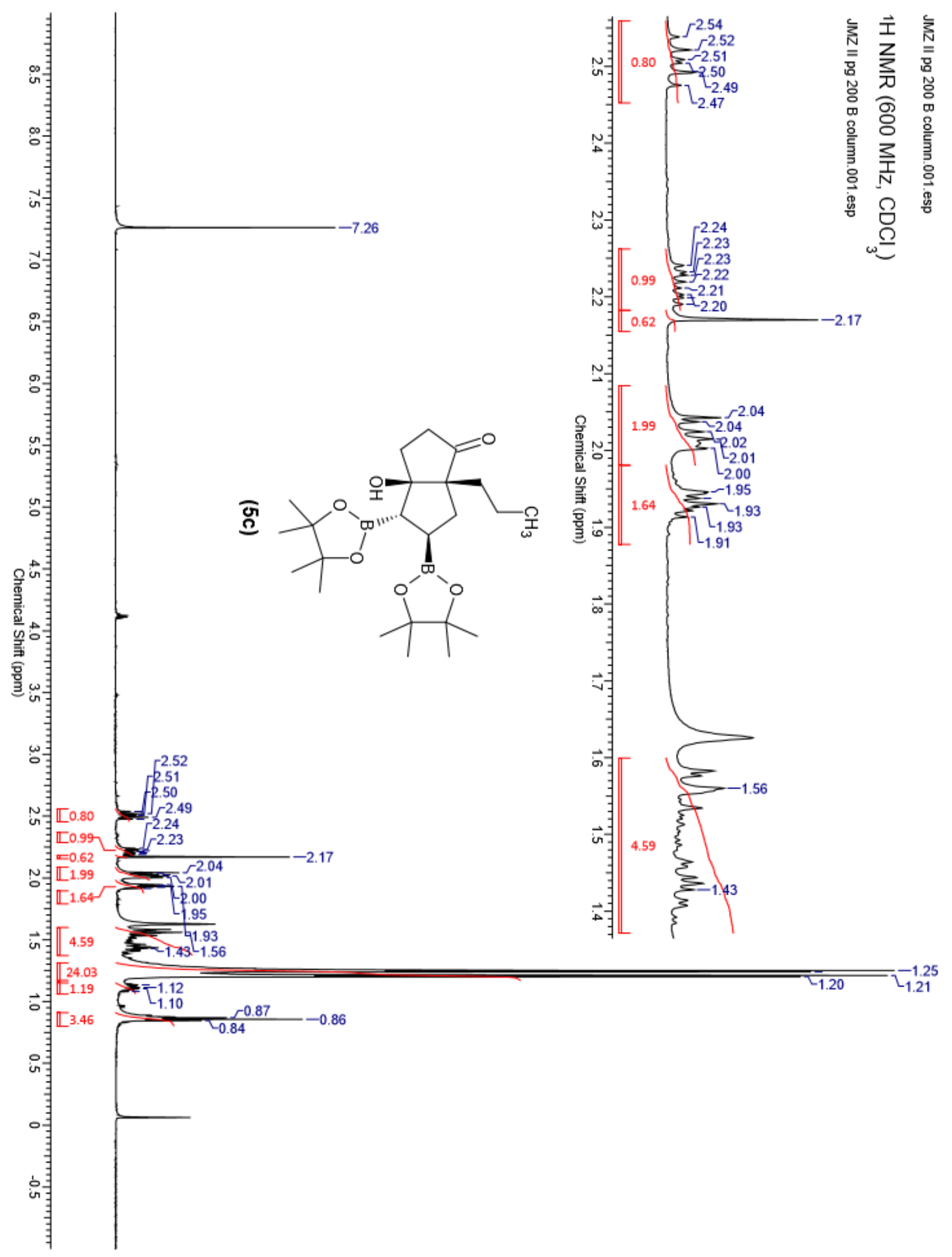




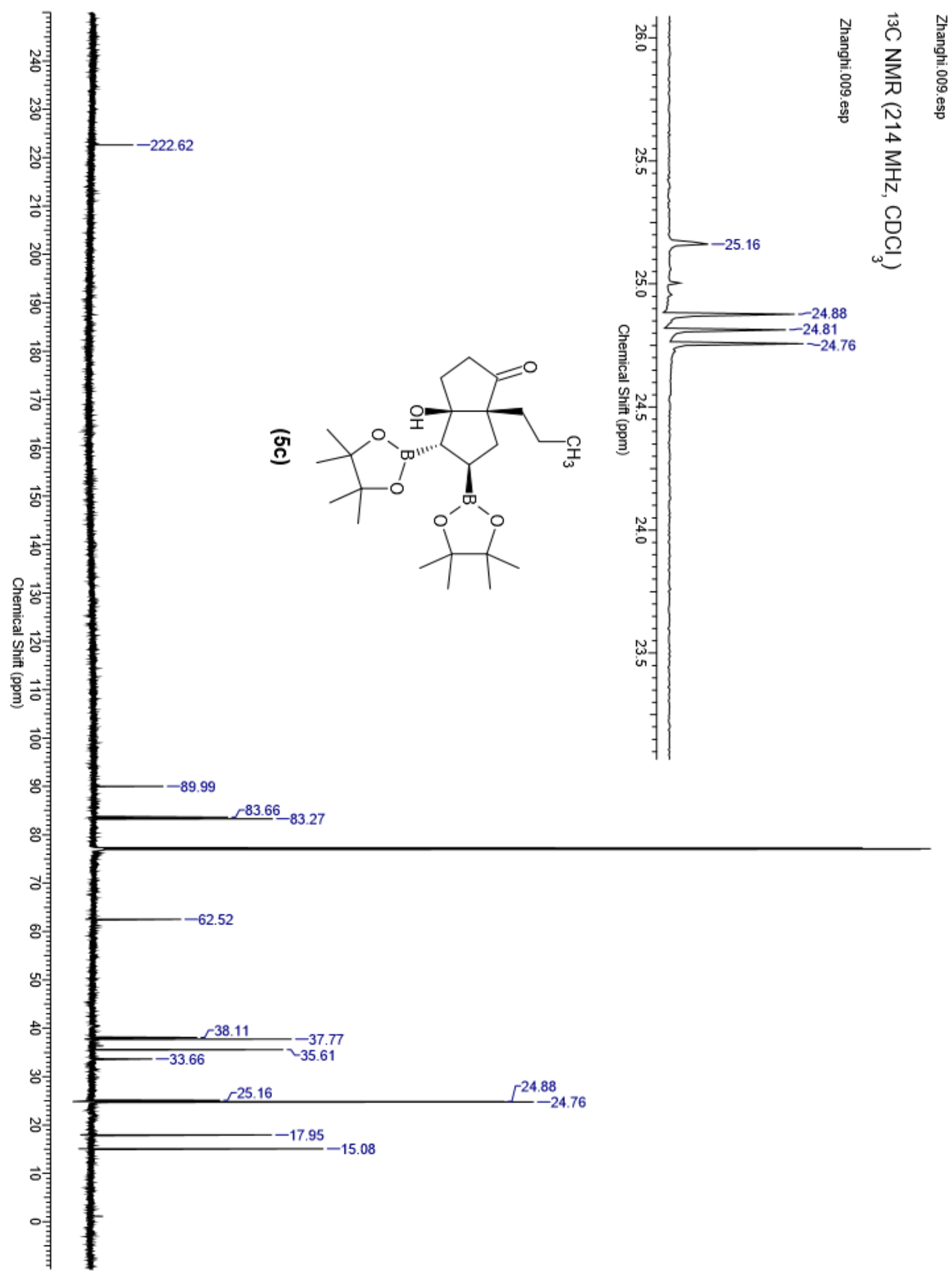




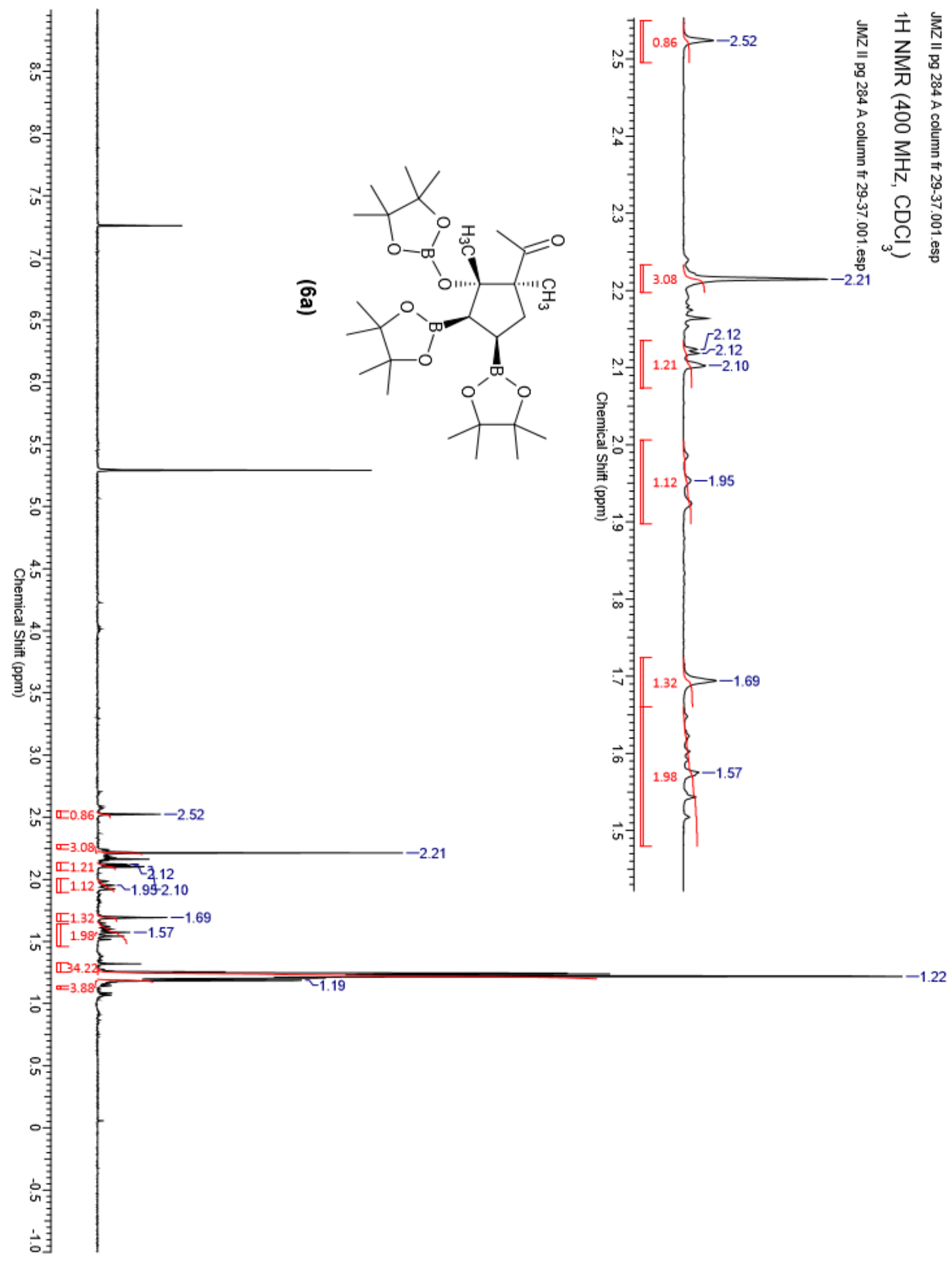




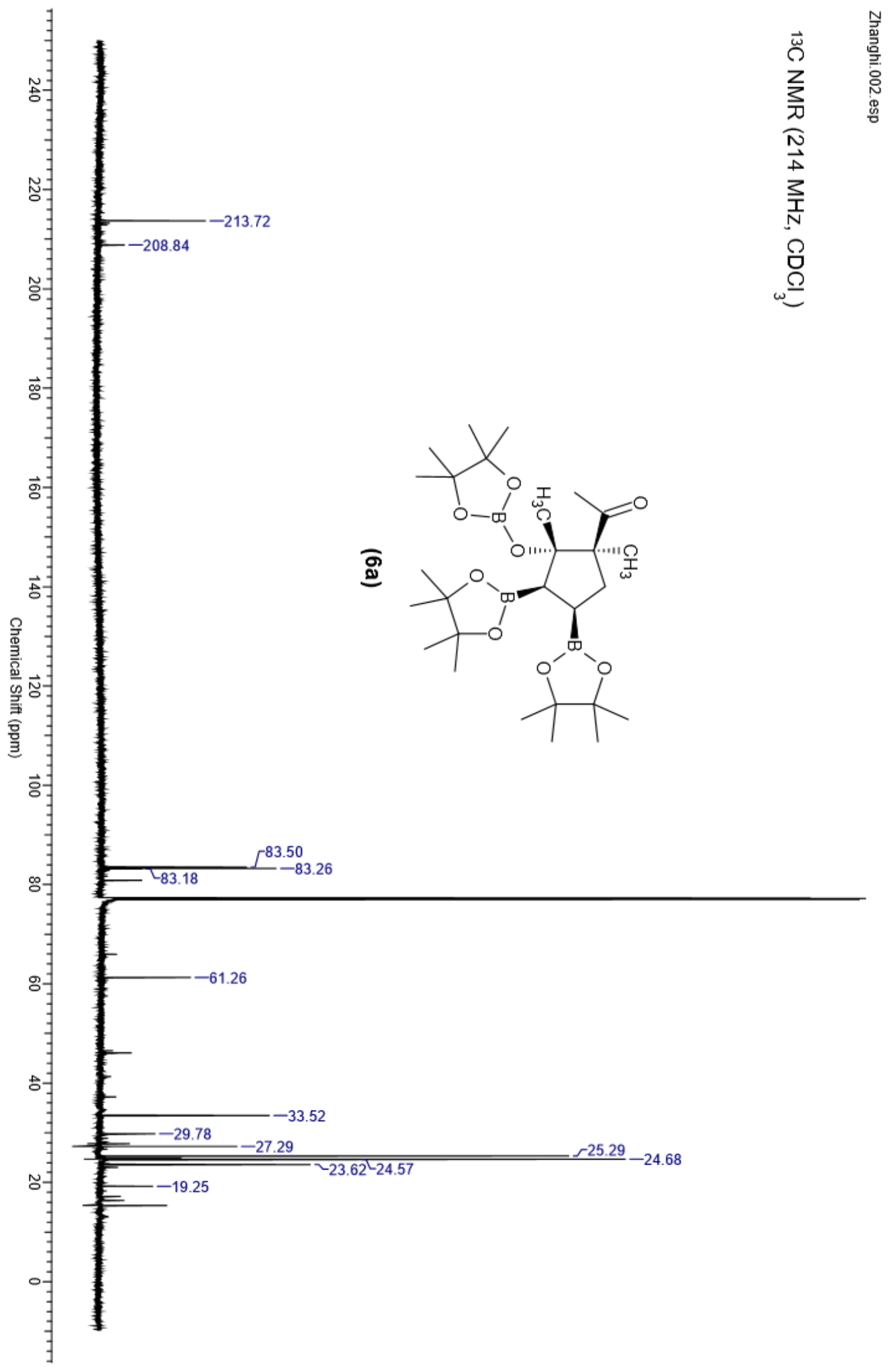




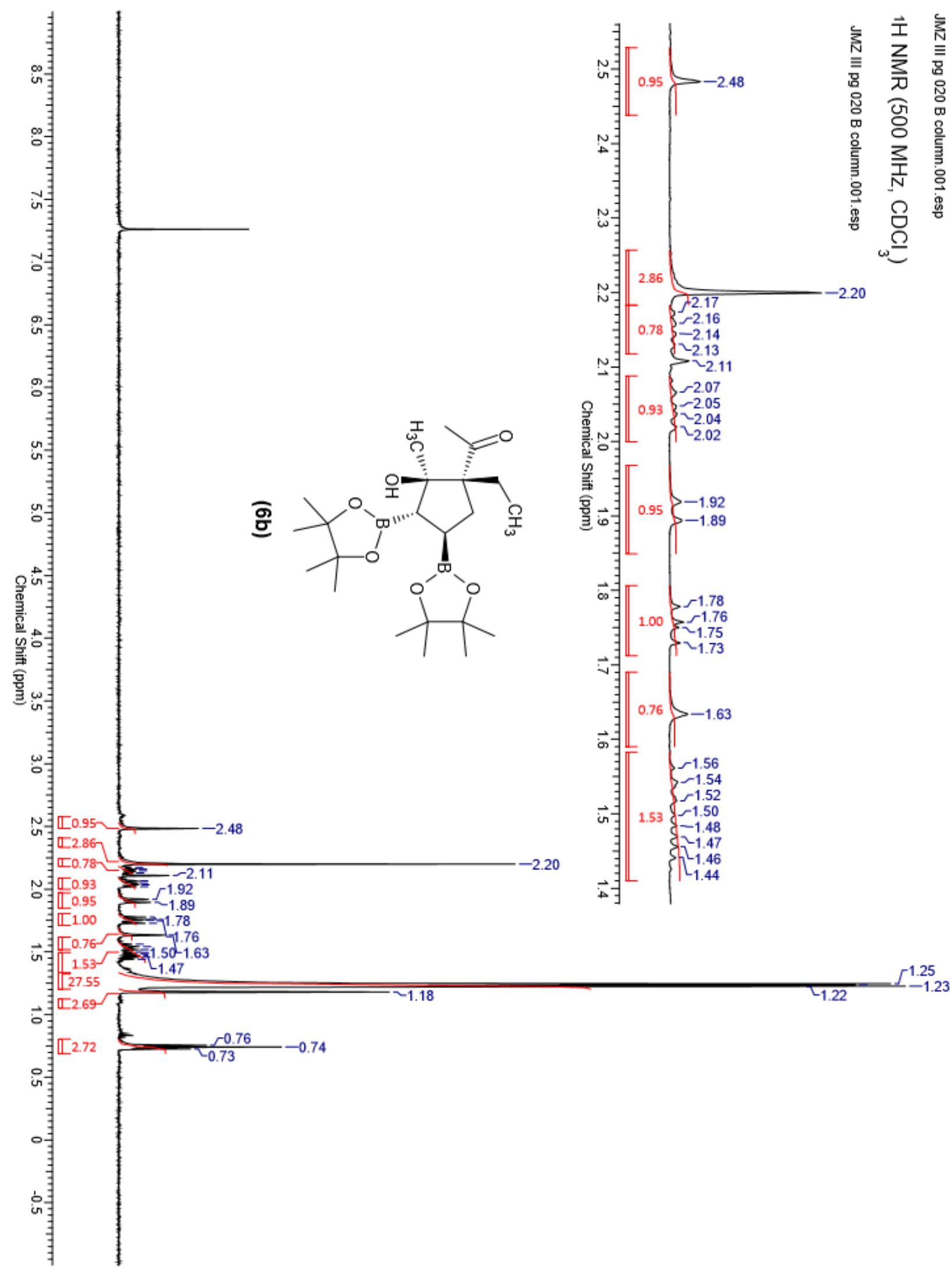




$$
L
$$




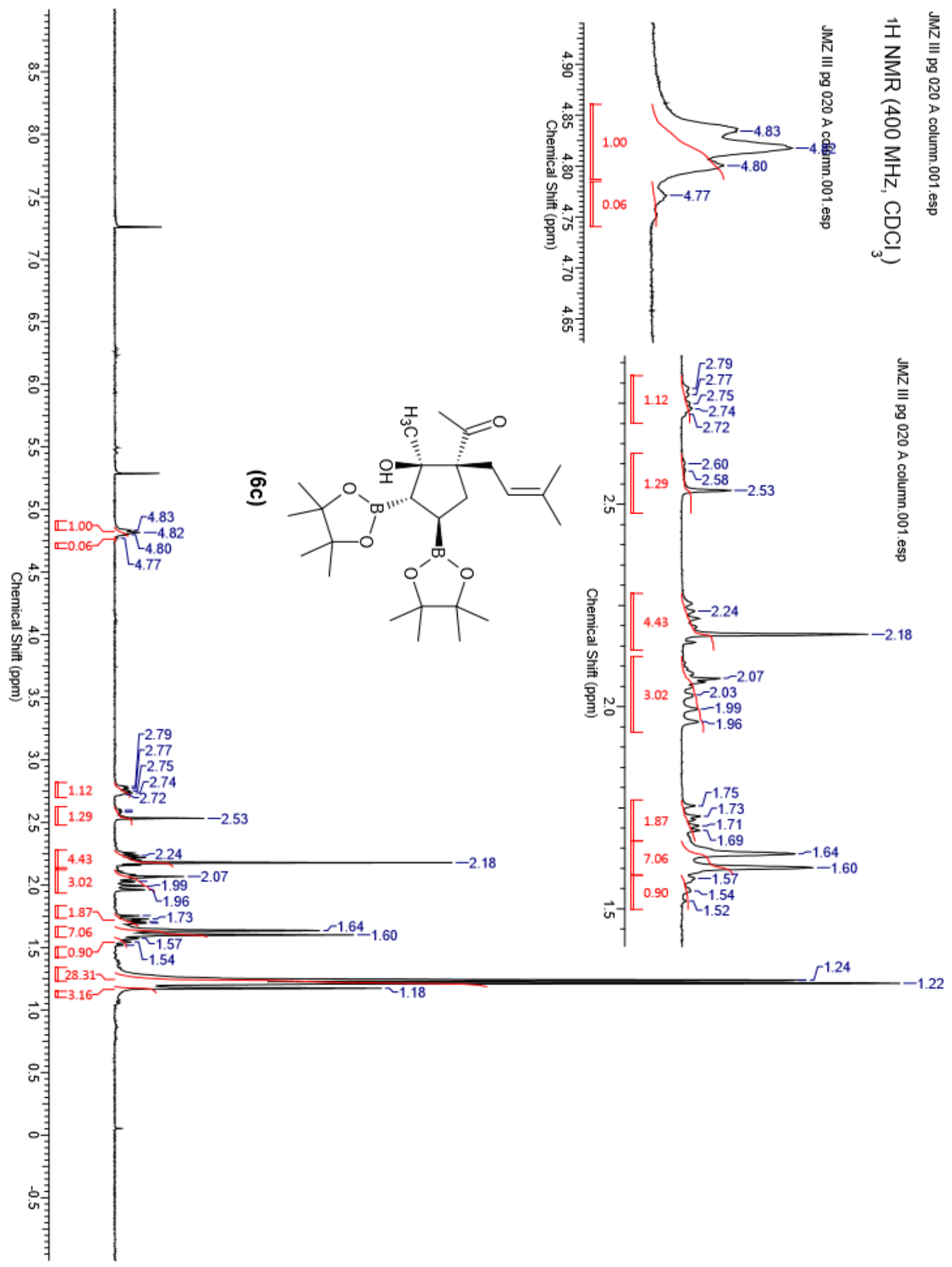




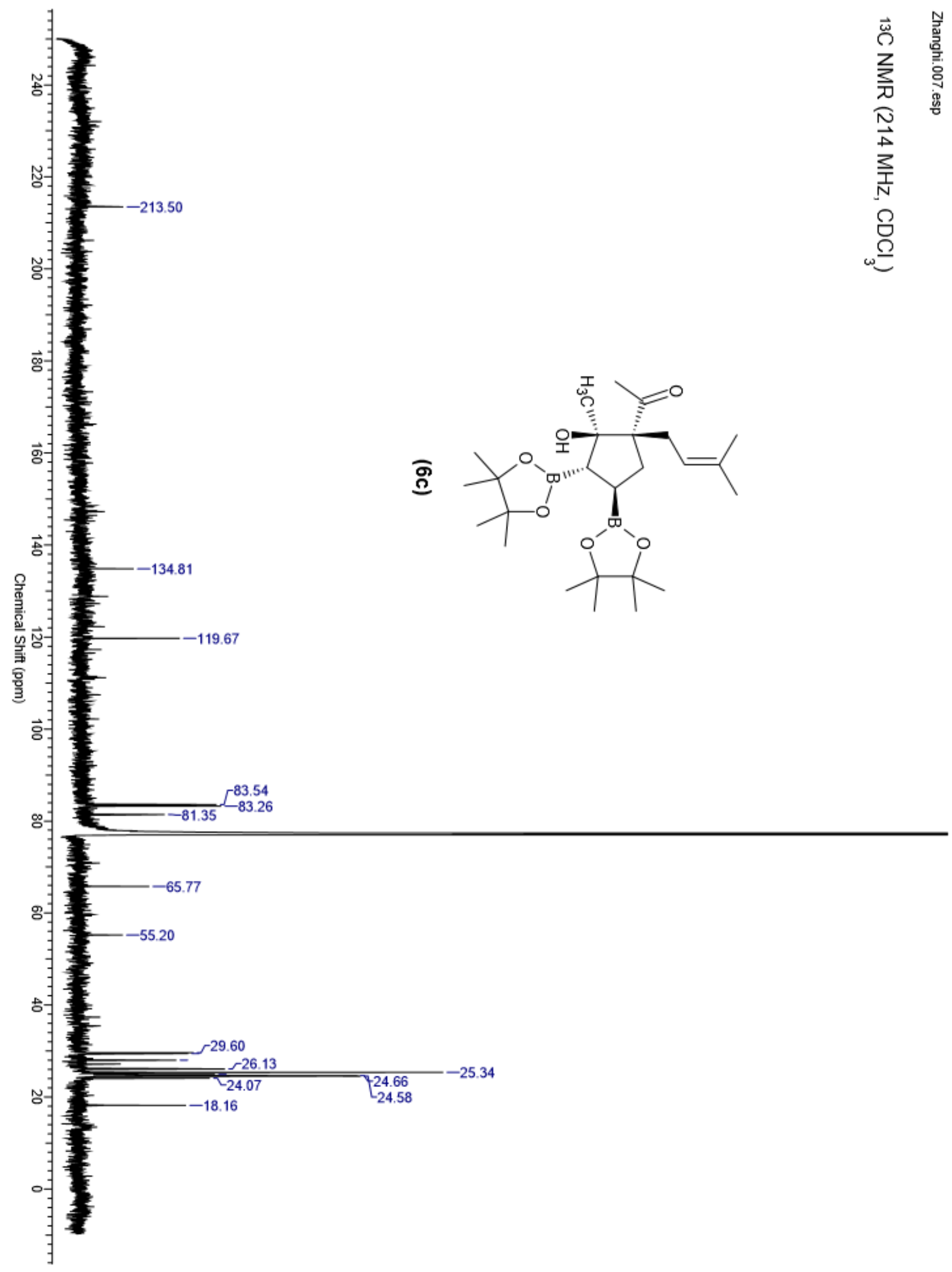




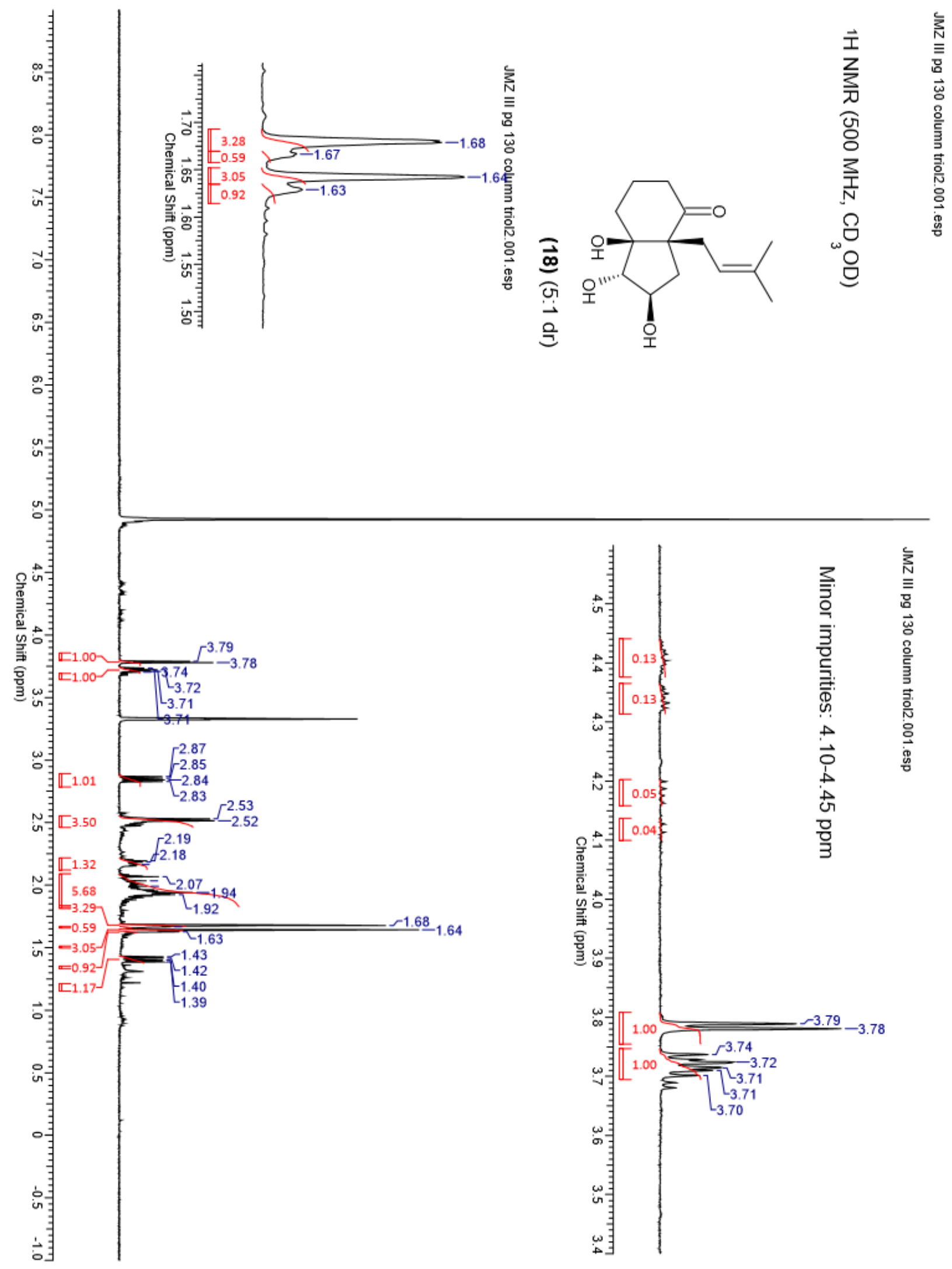




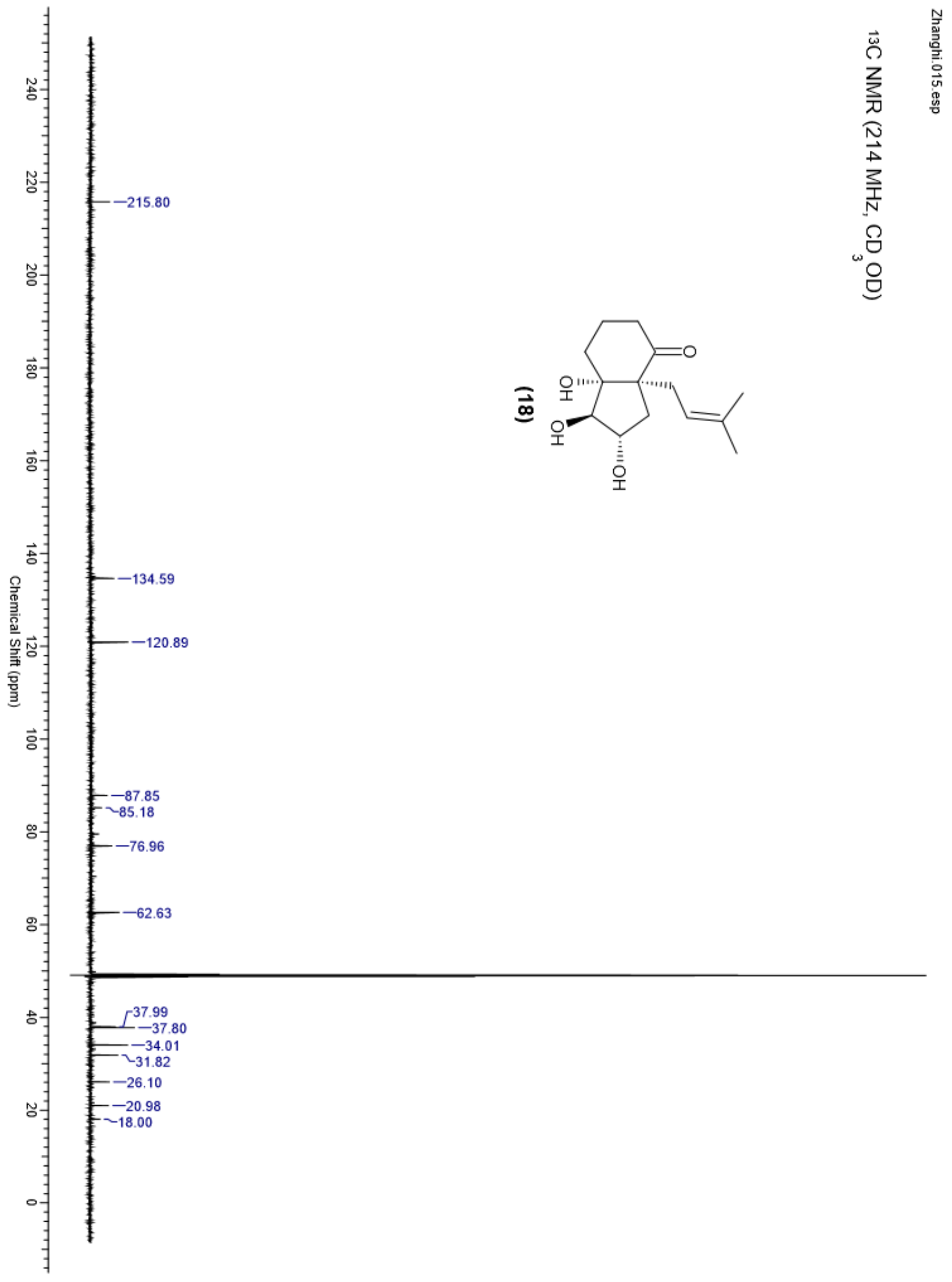




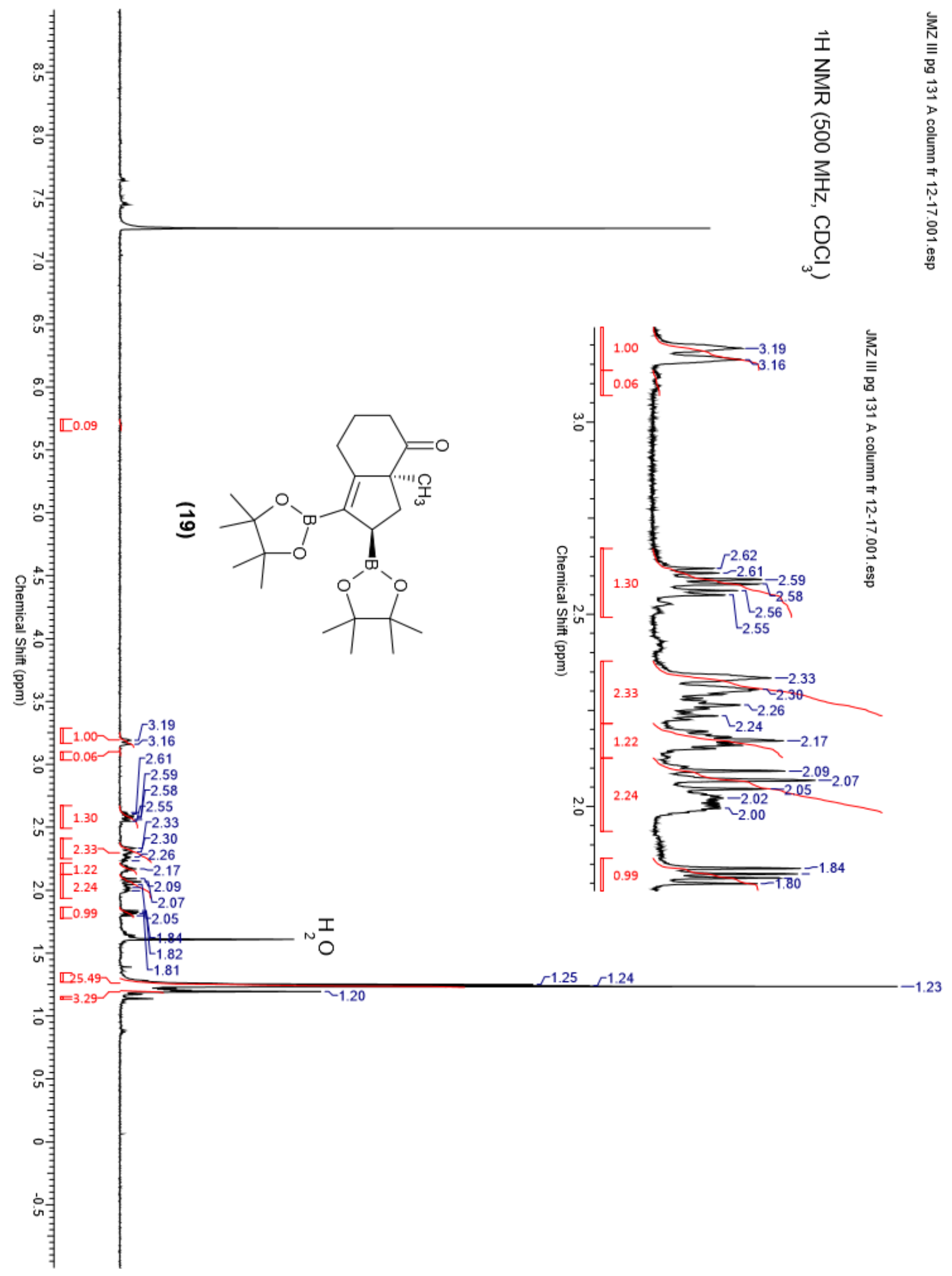




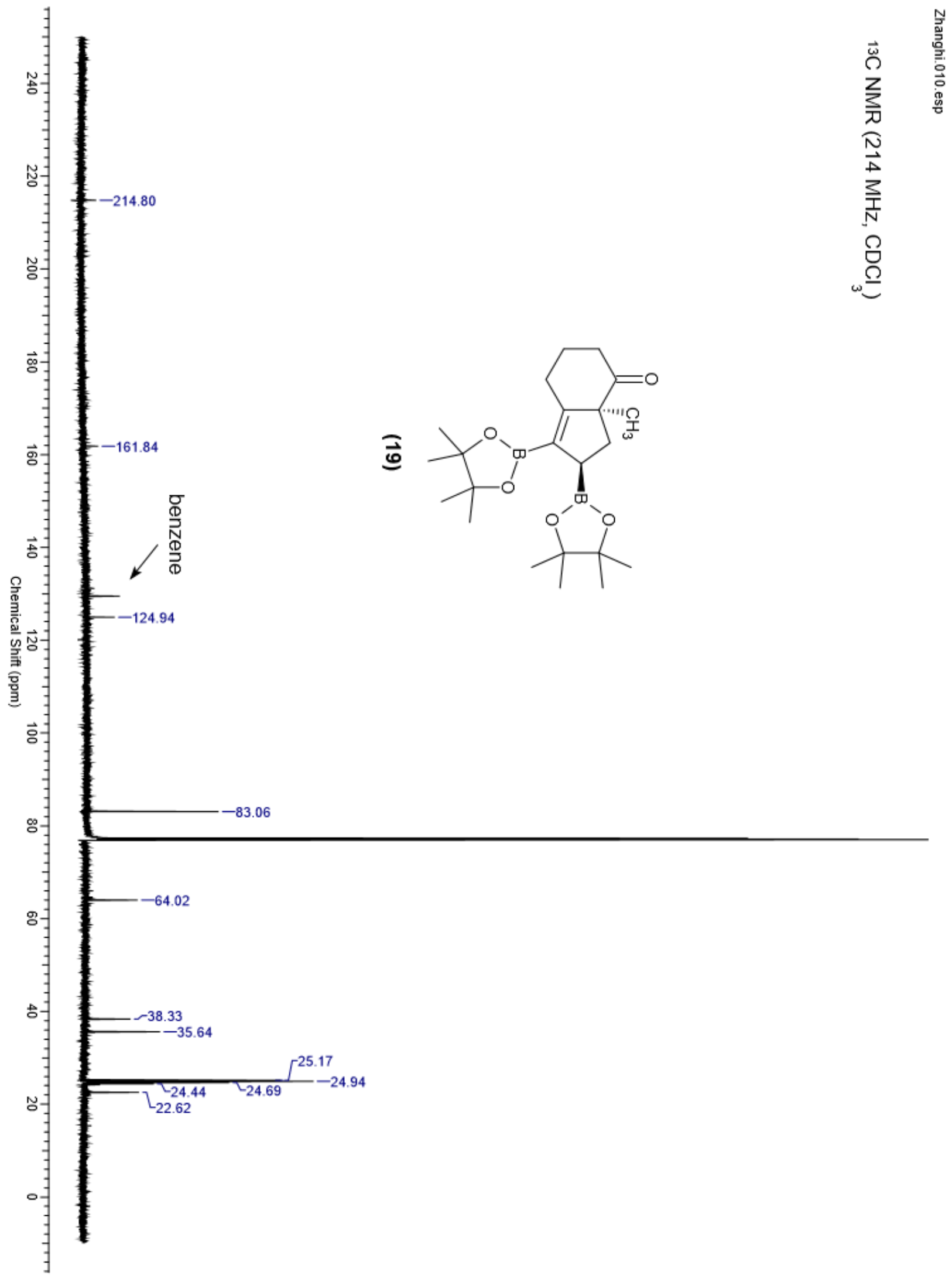




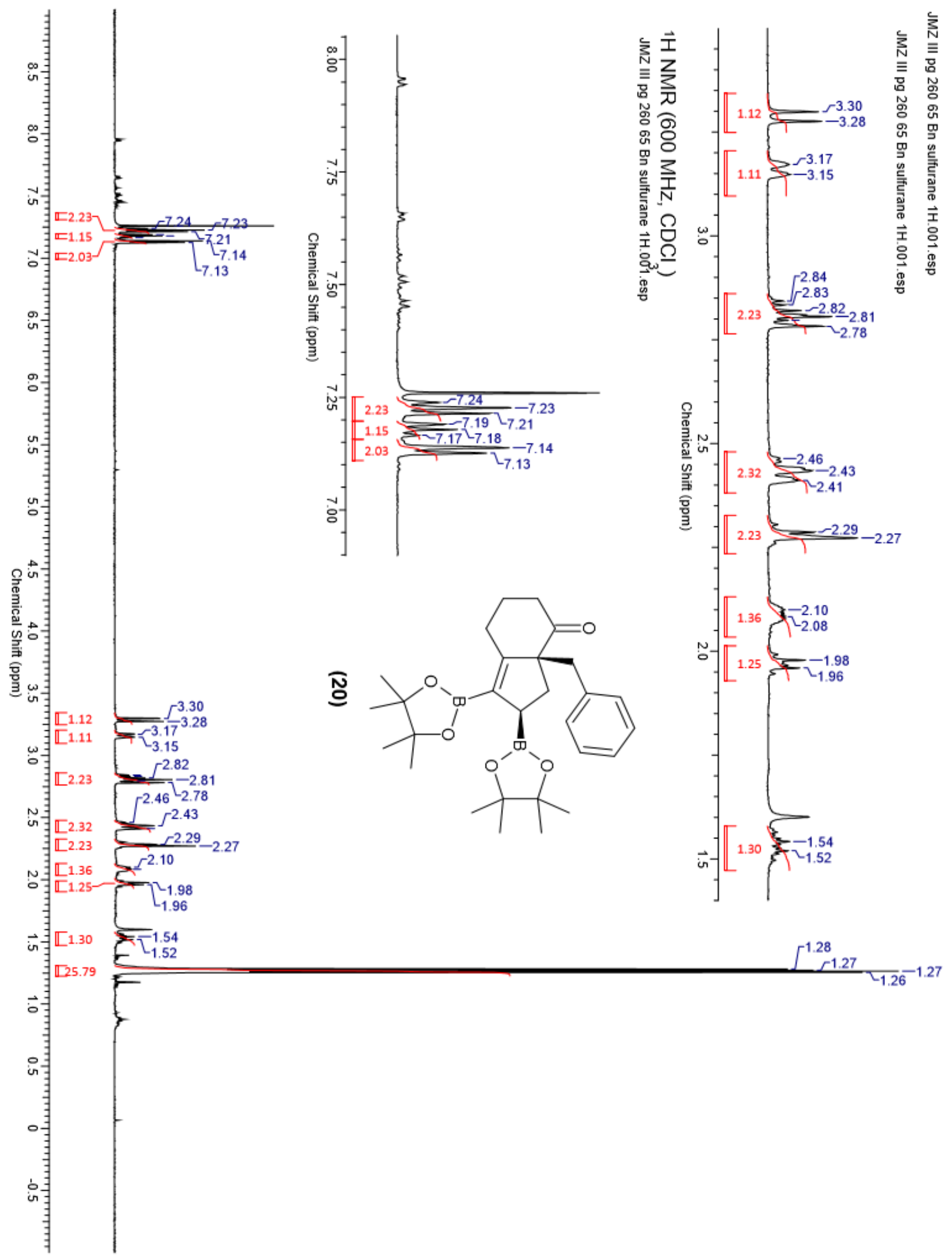




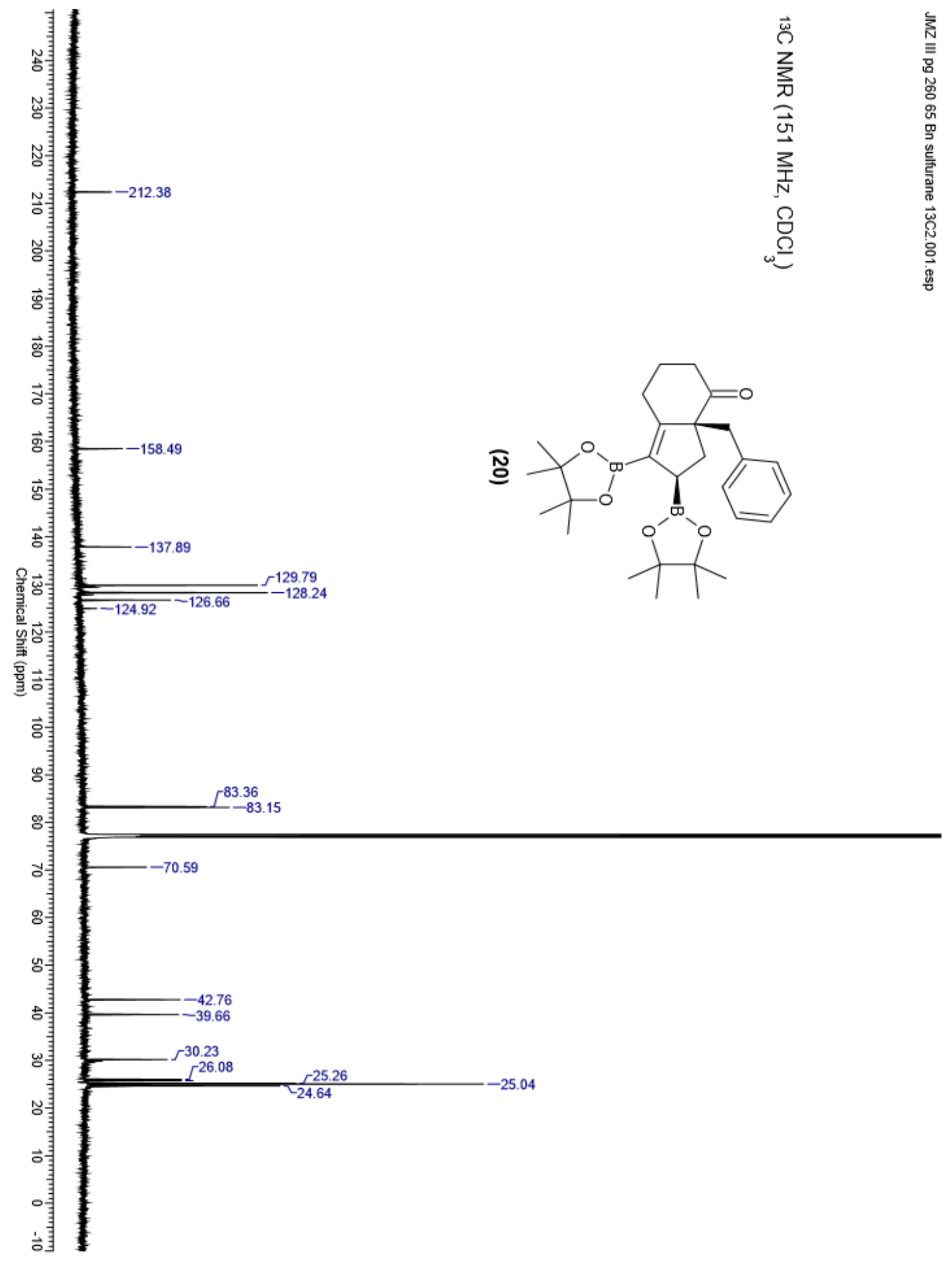




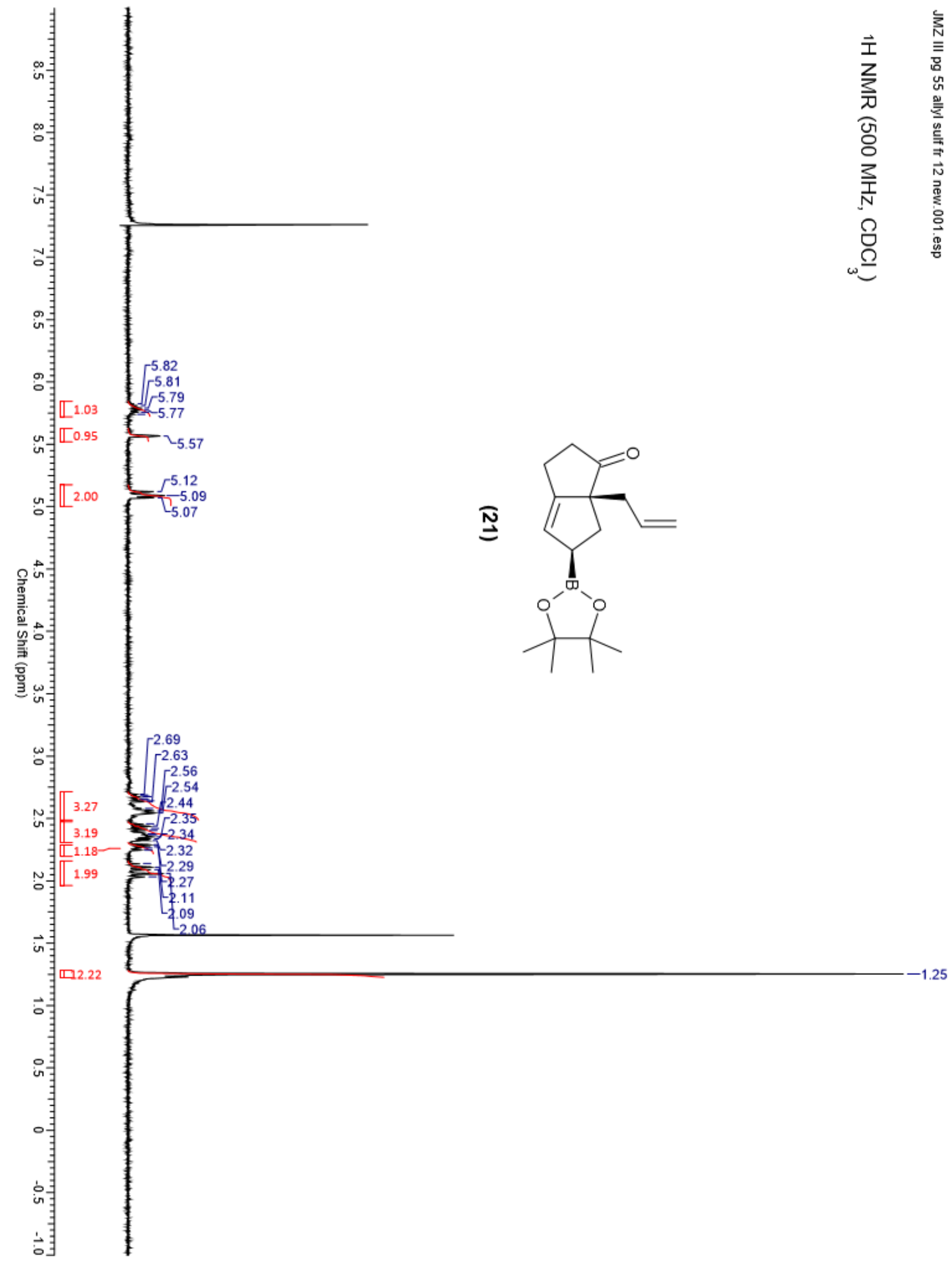



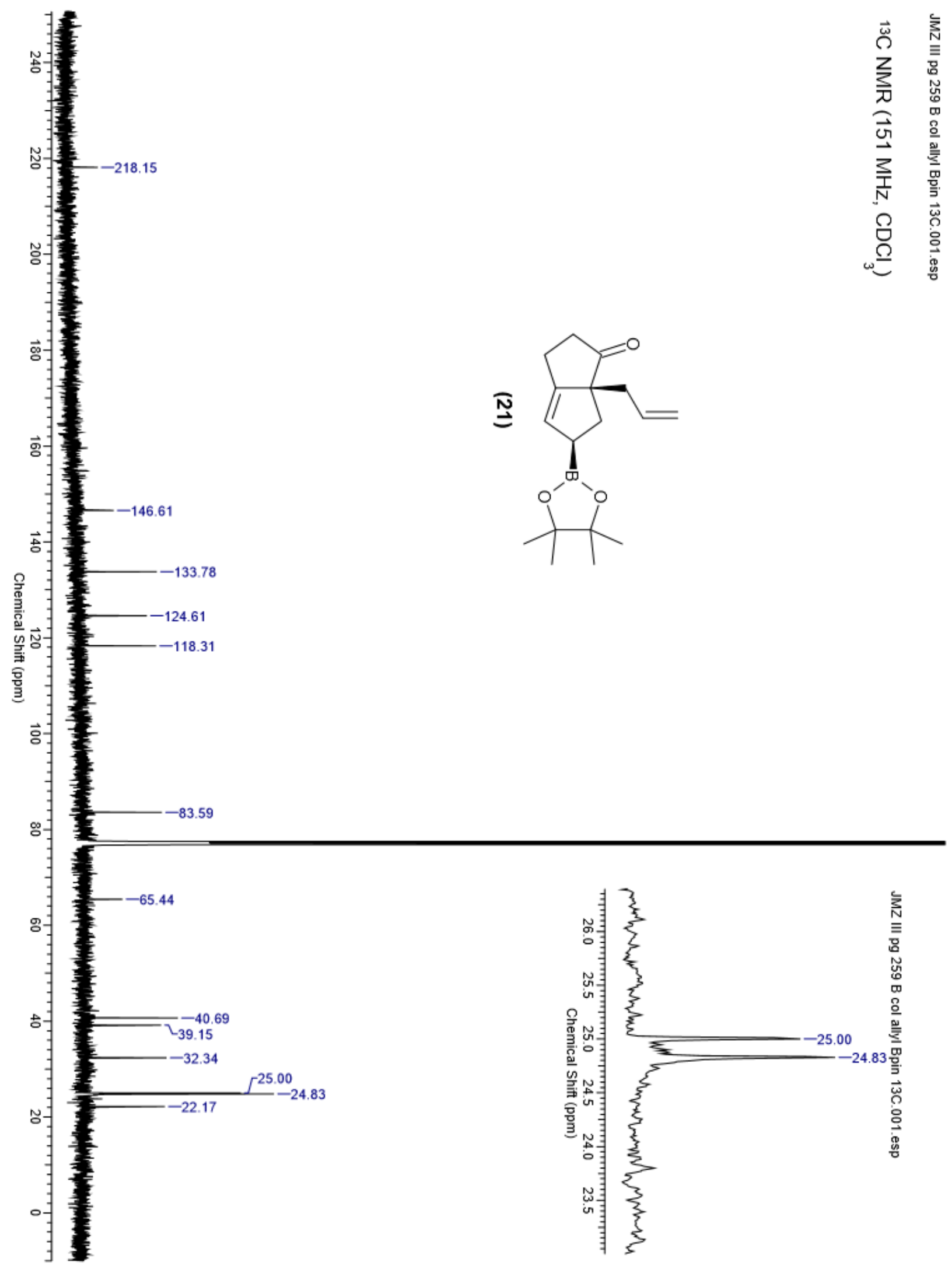


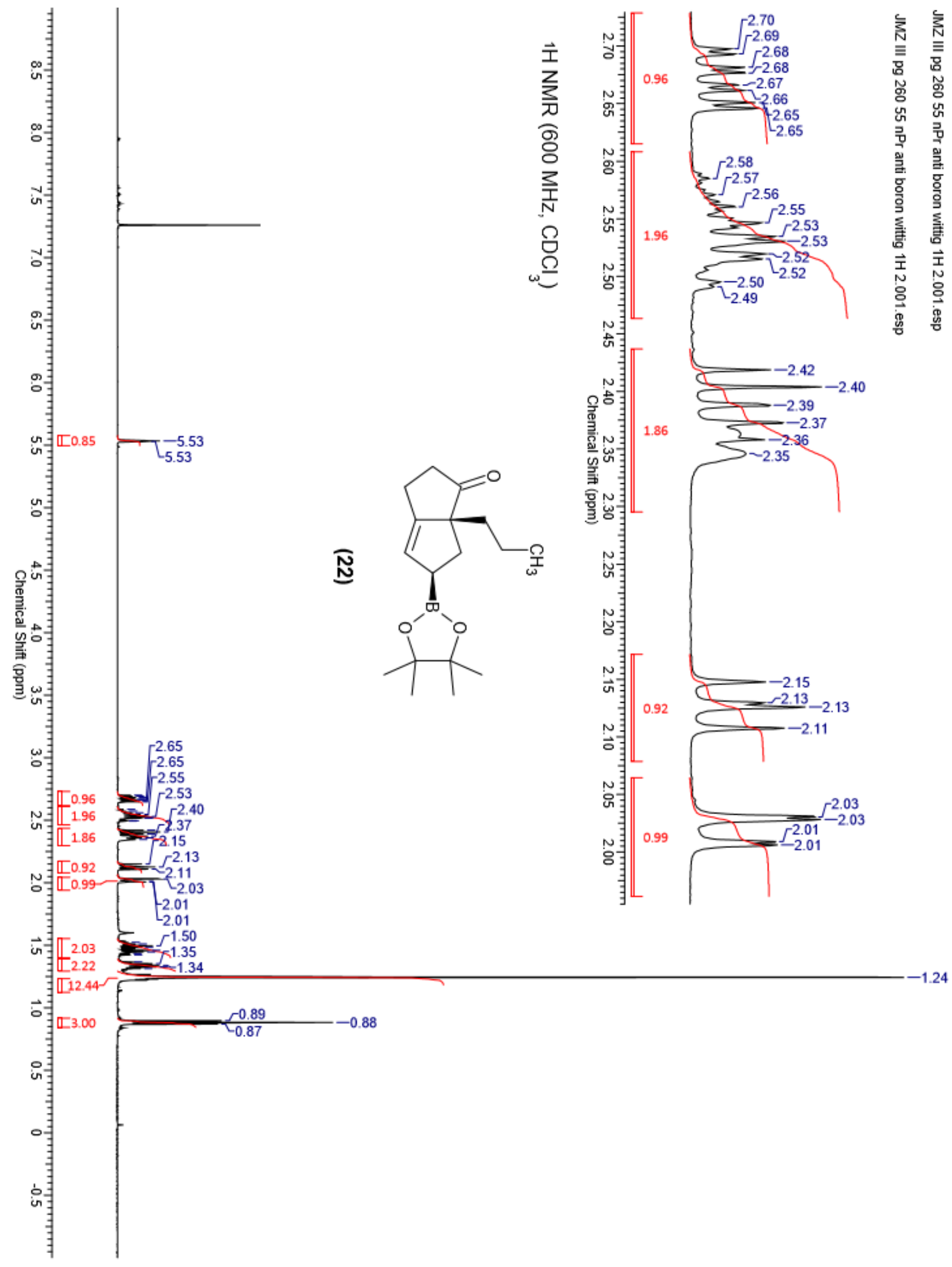



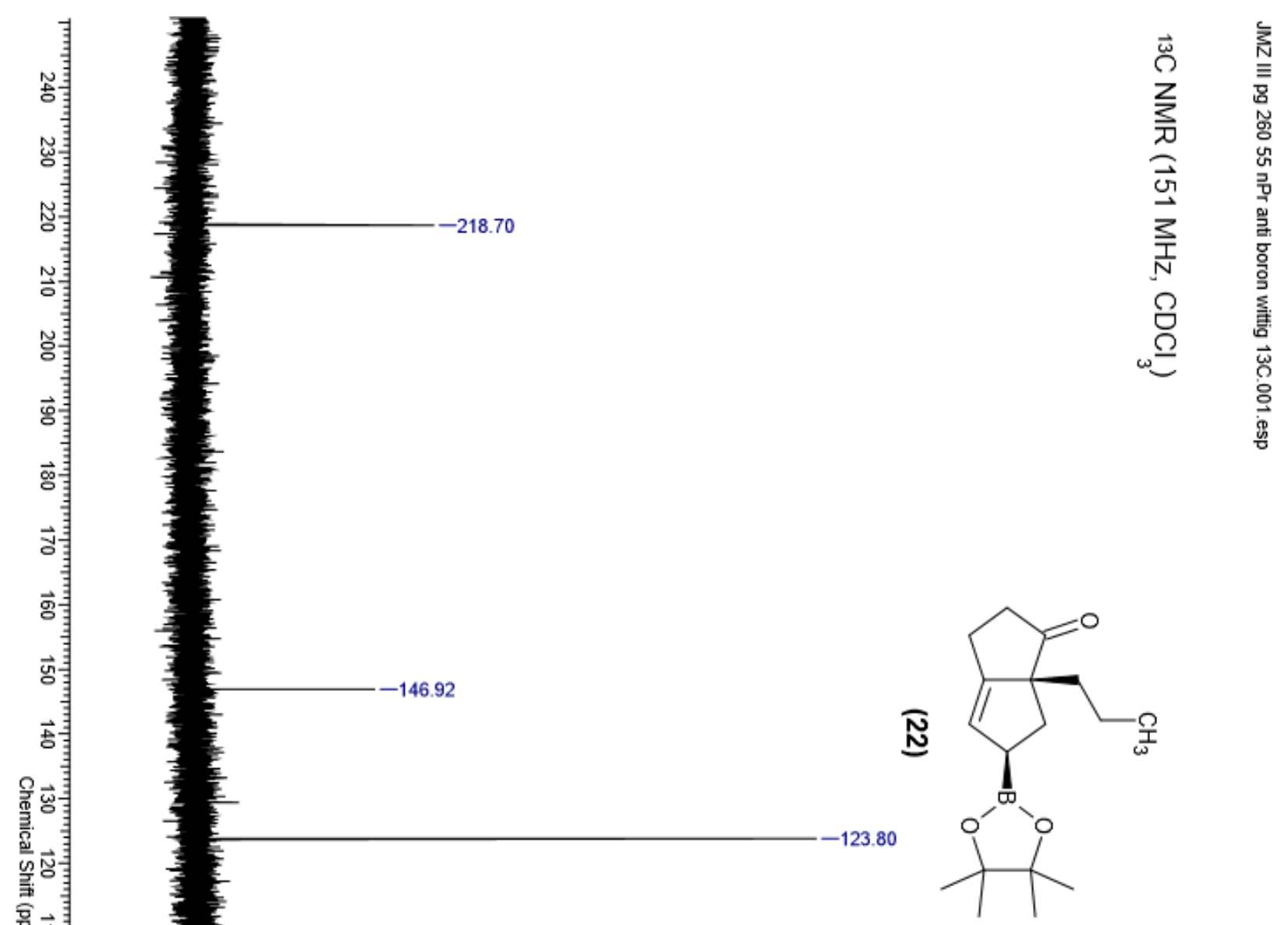
商

홍

जै

点

产 흥

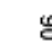

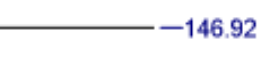




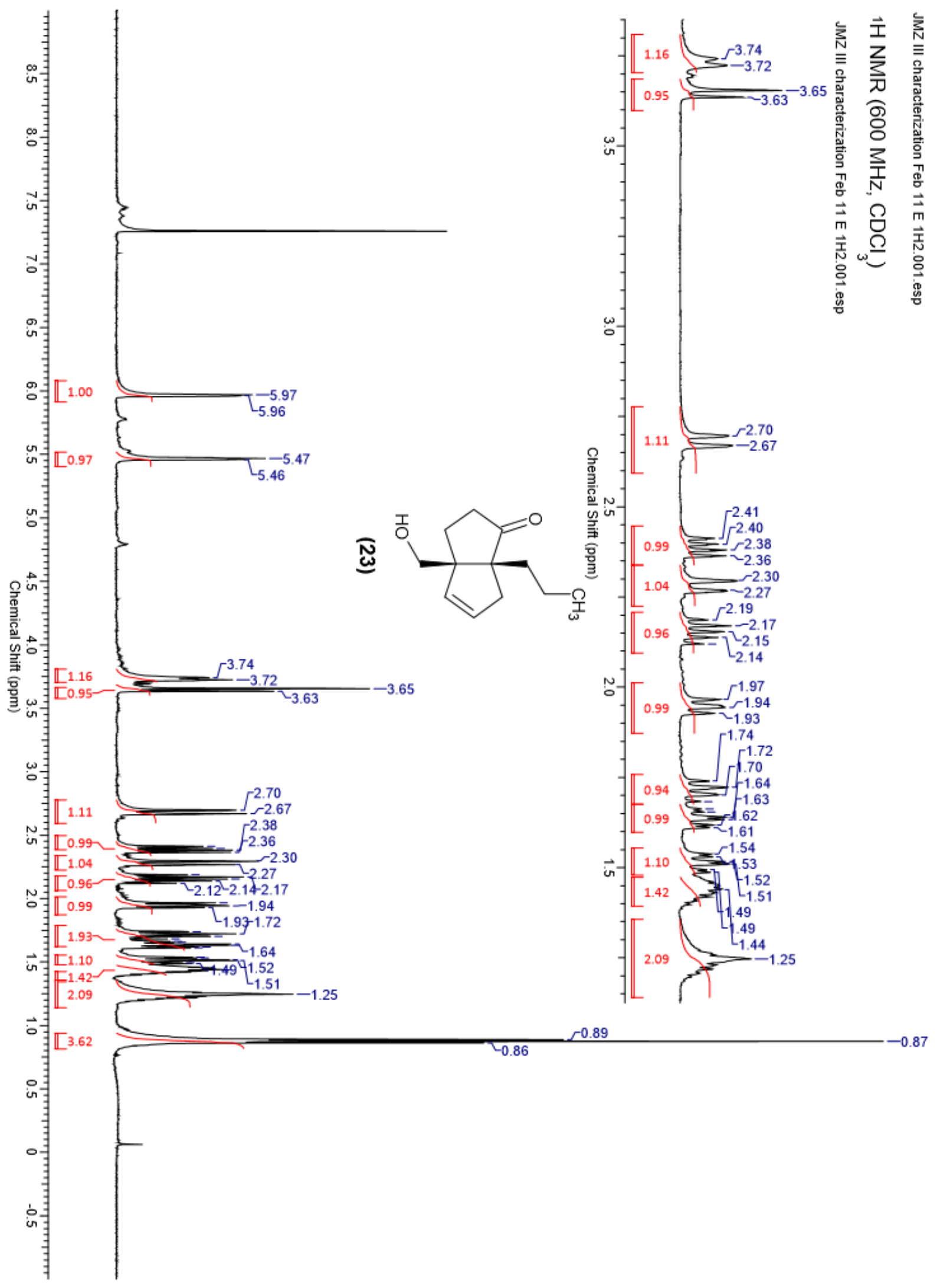




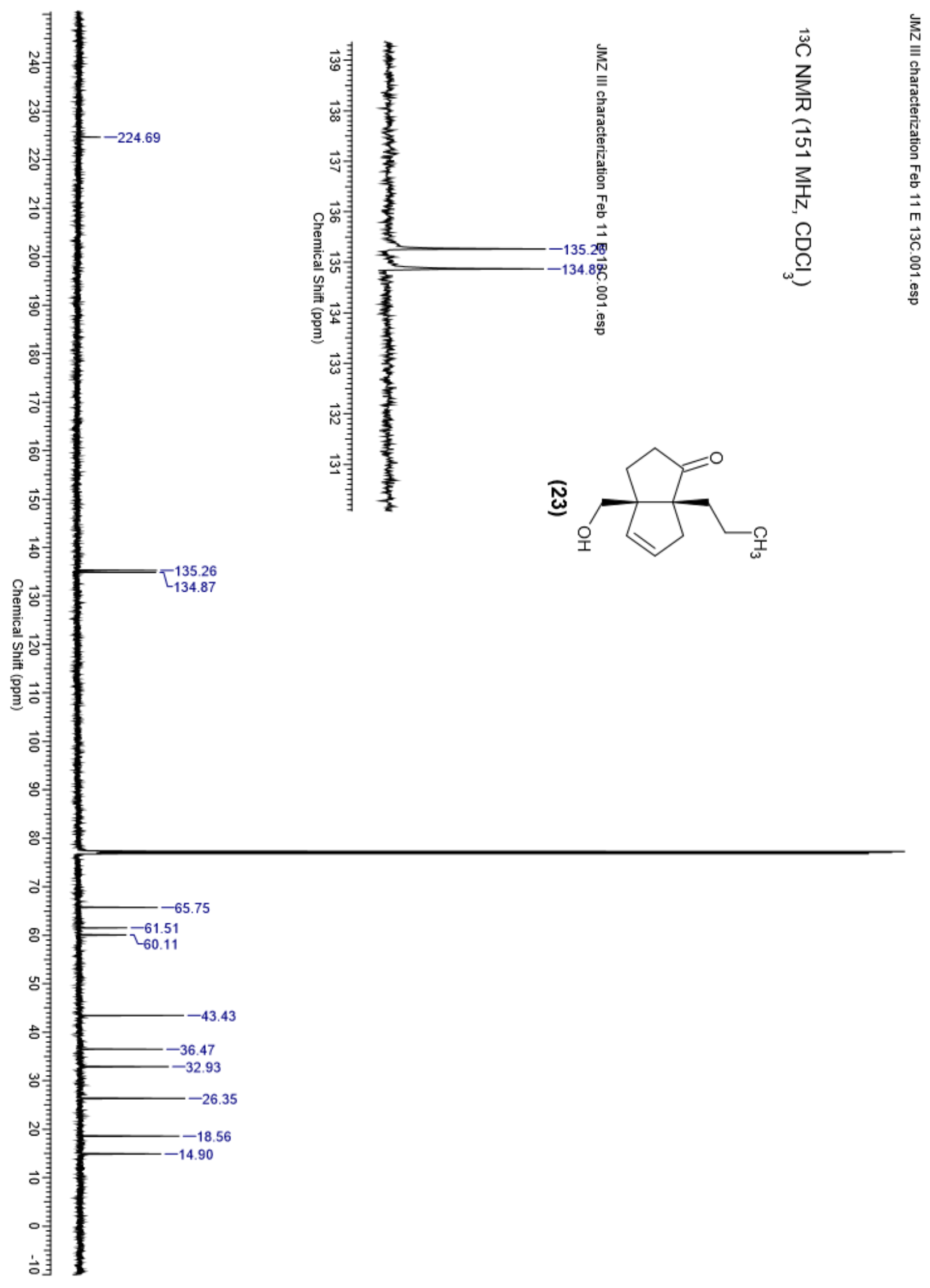




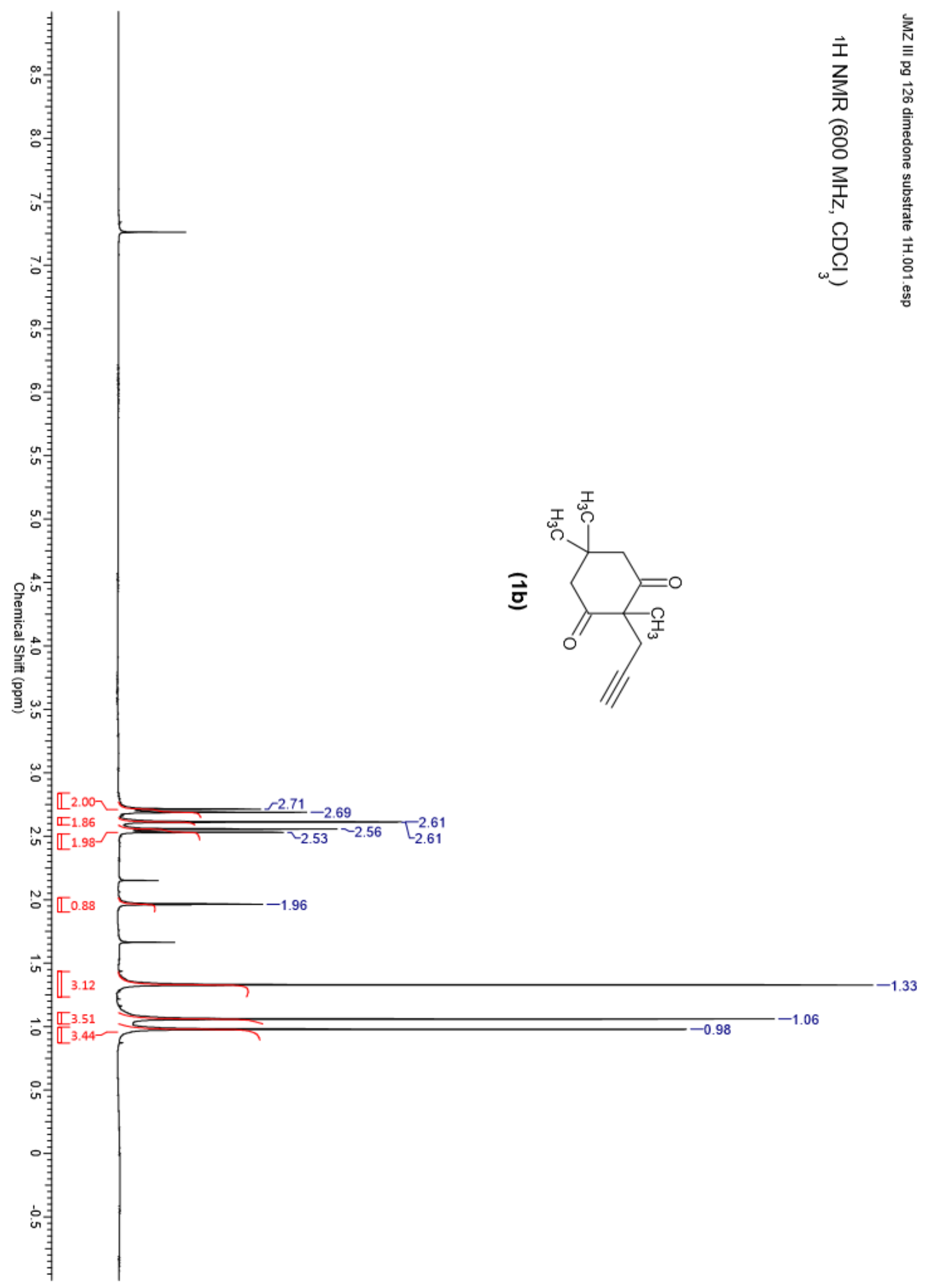




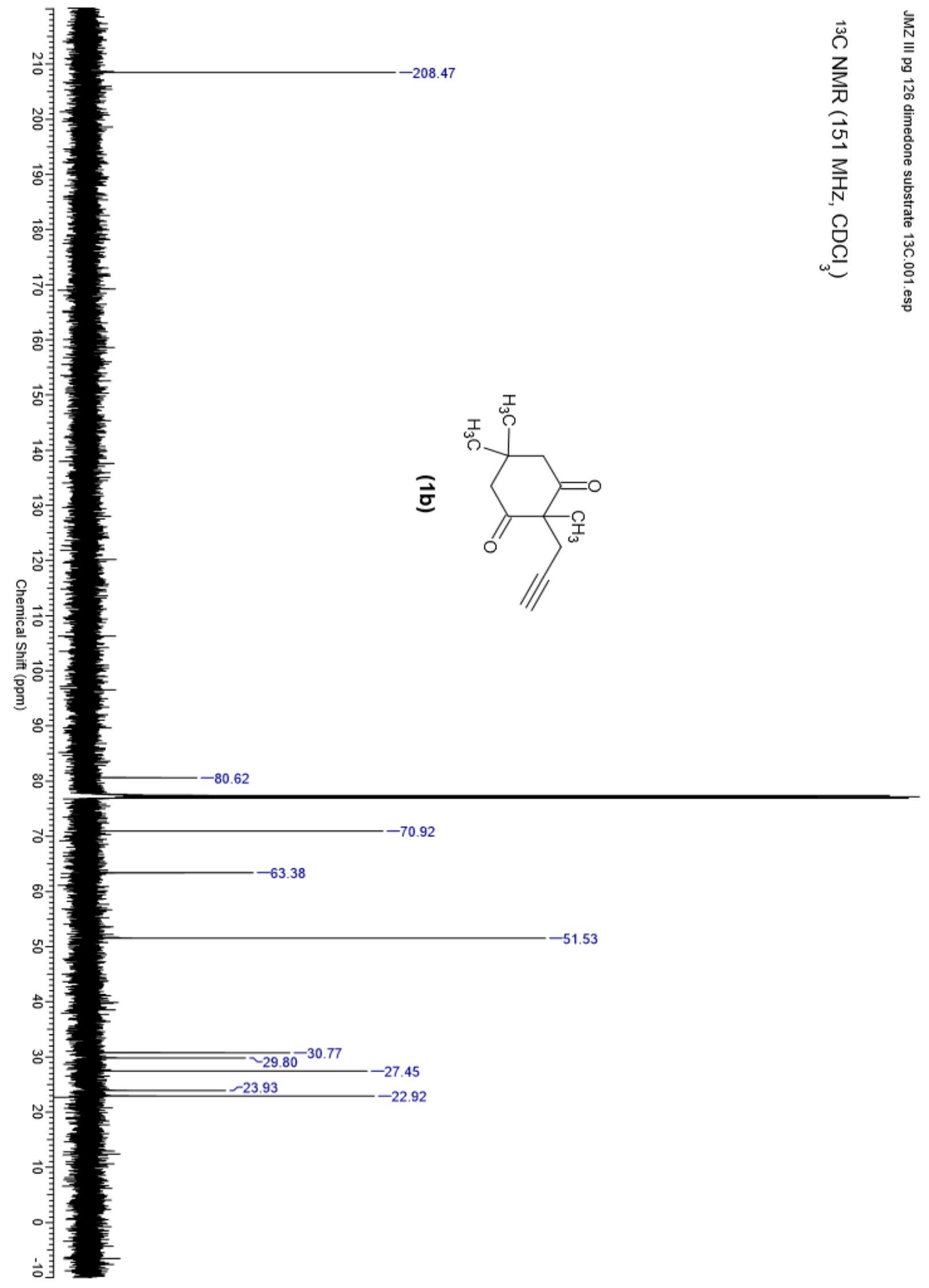




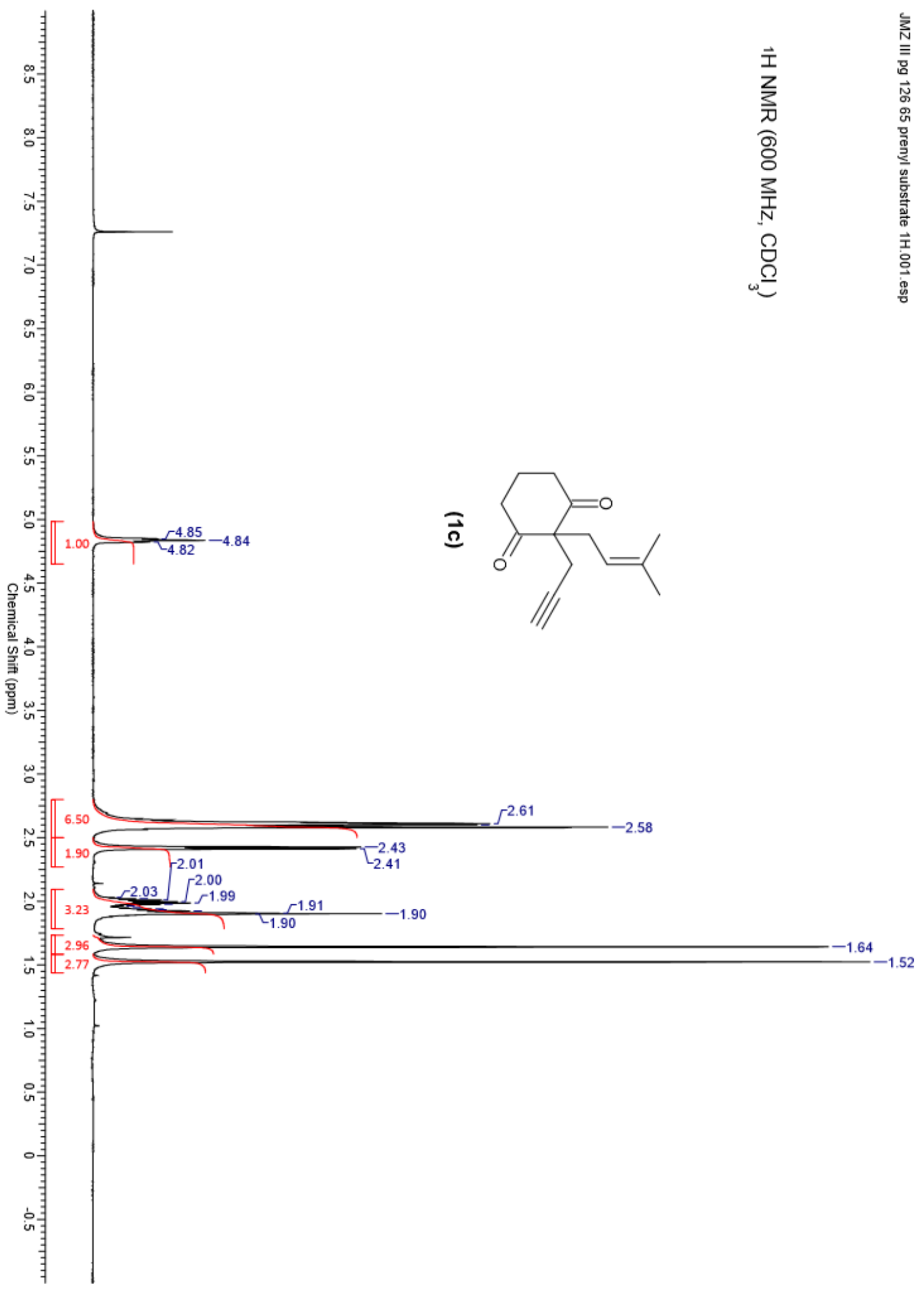




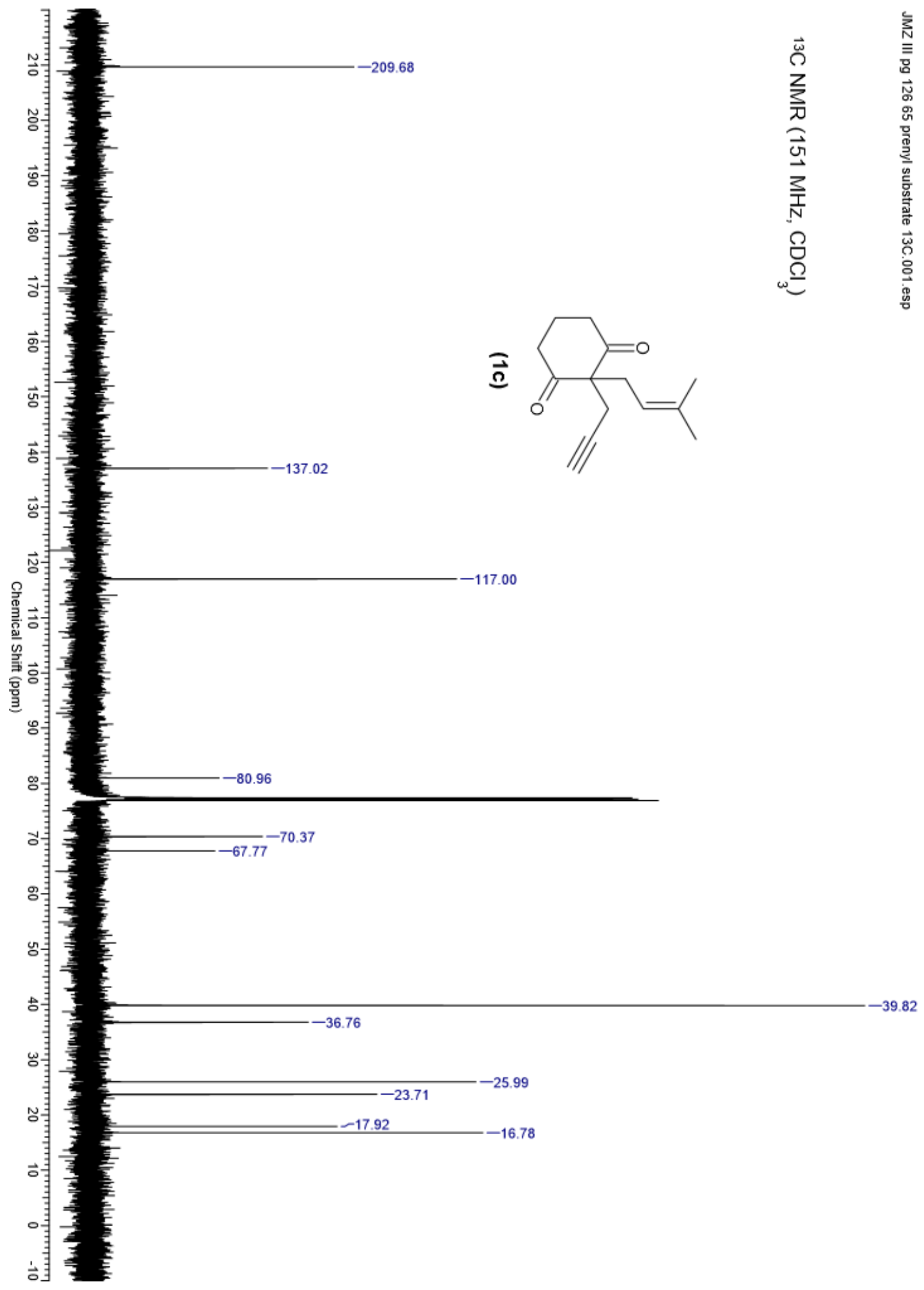




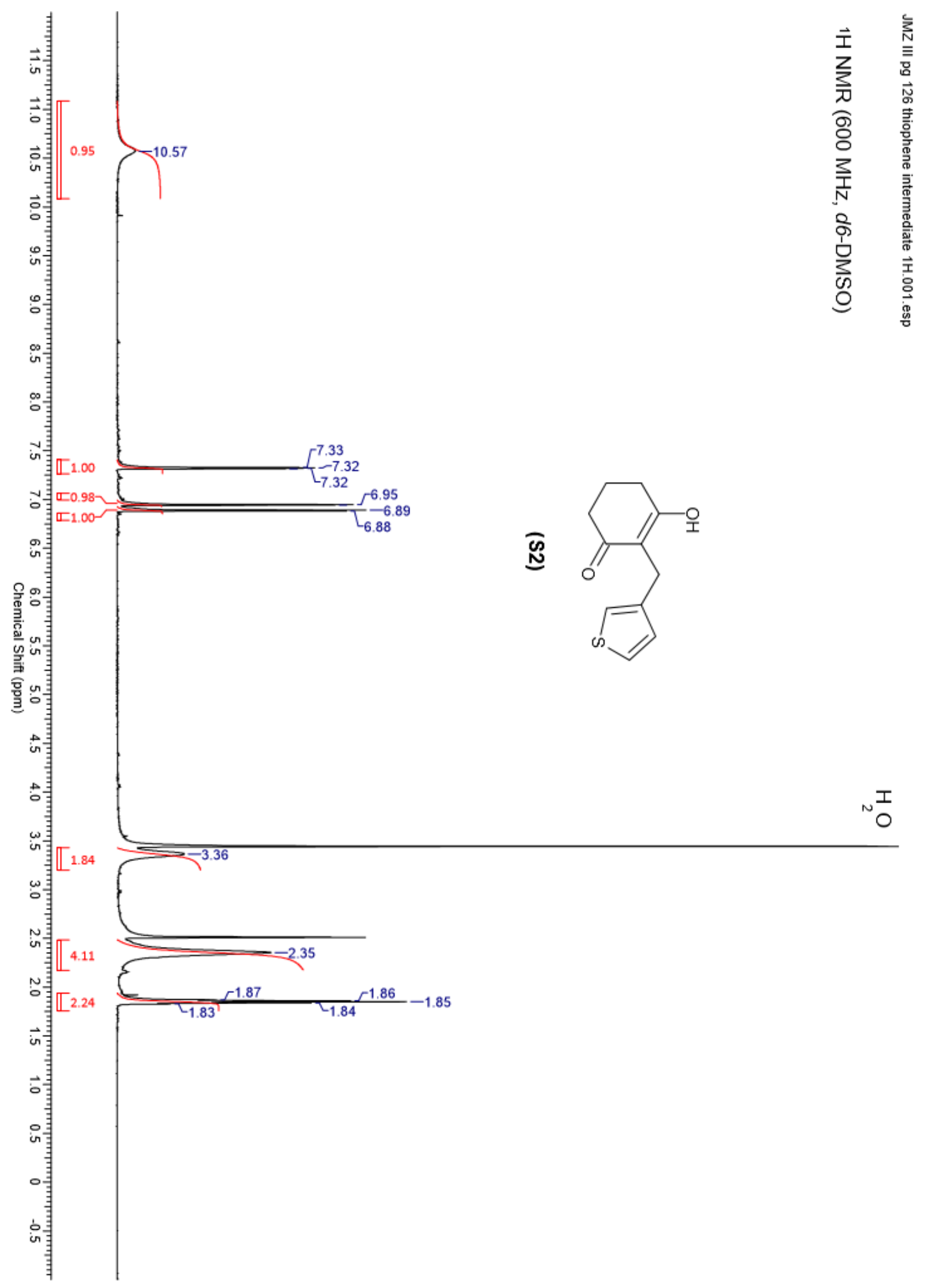




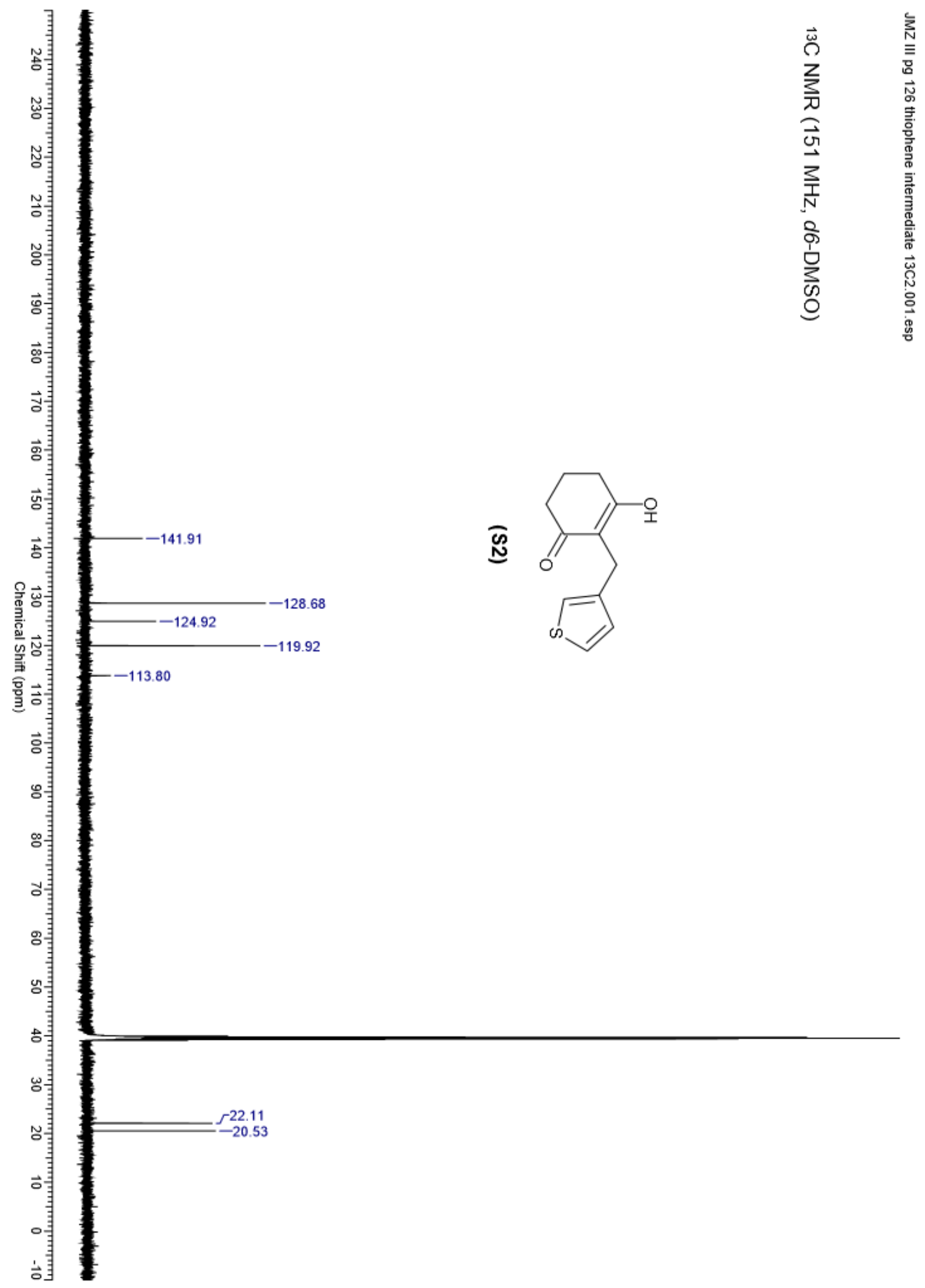




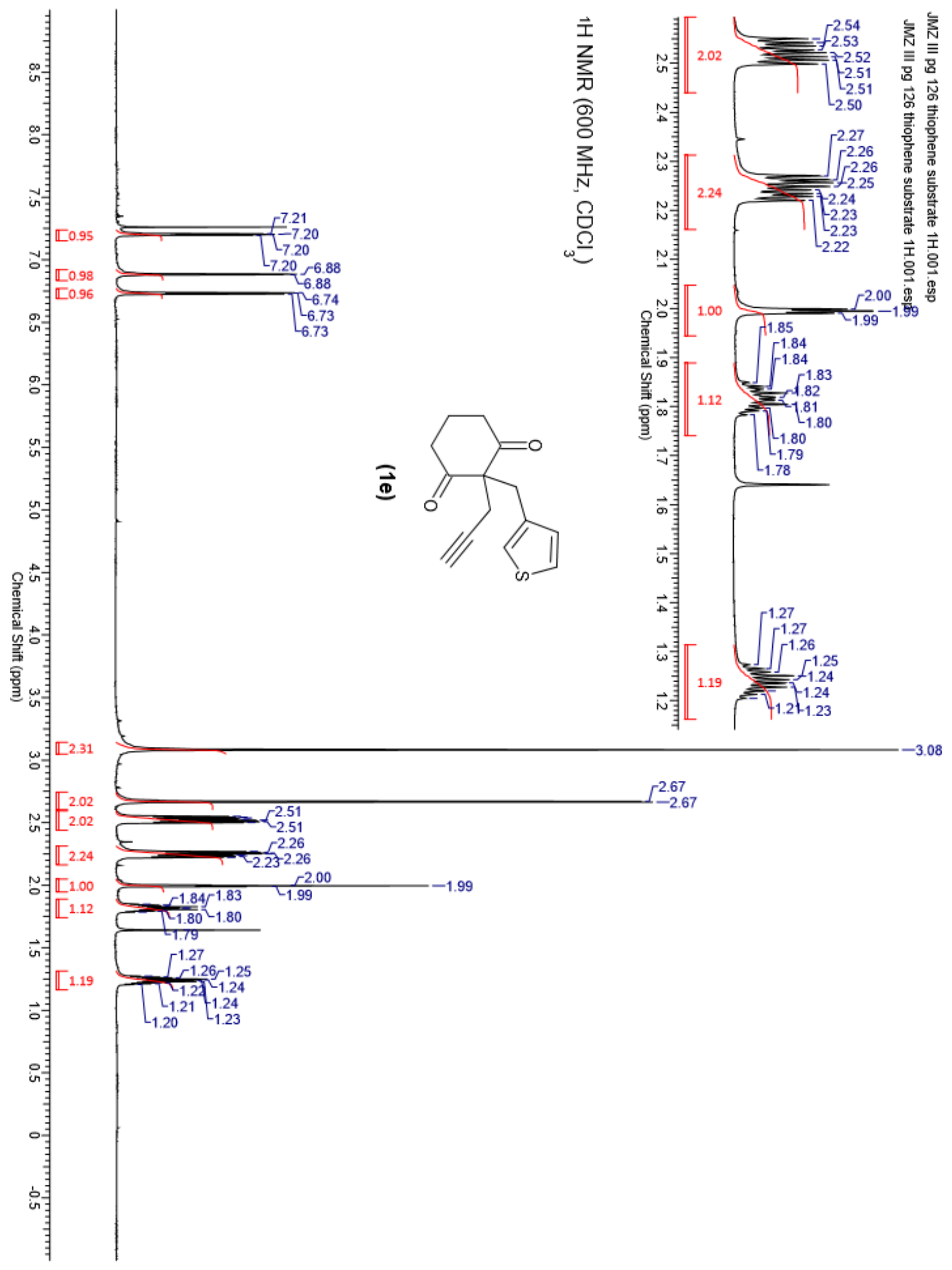




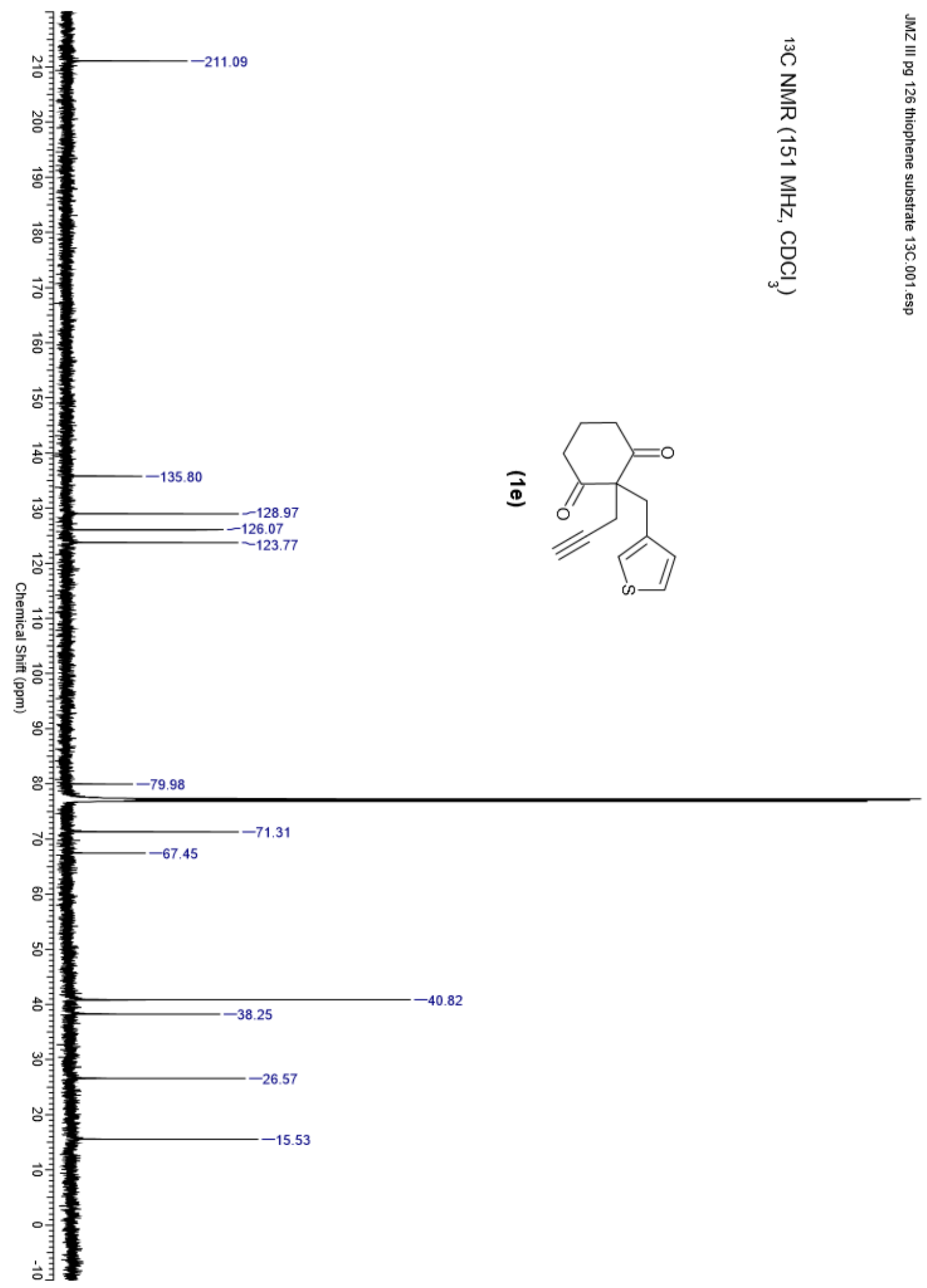




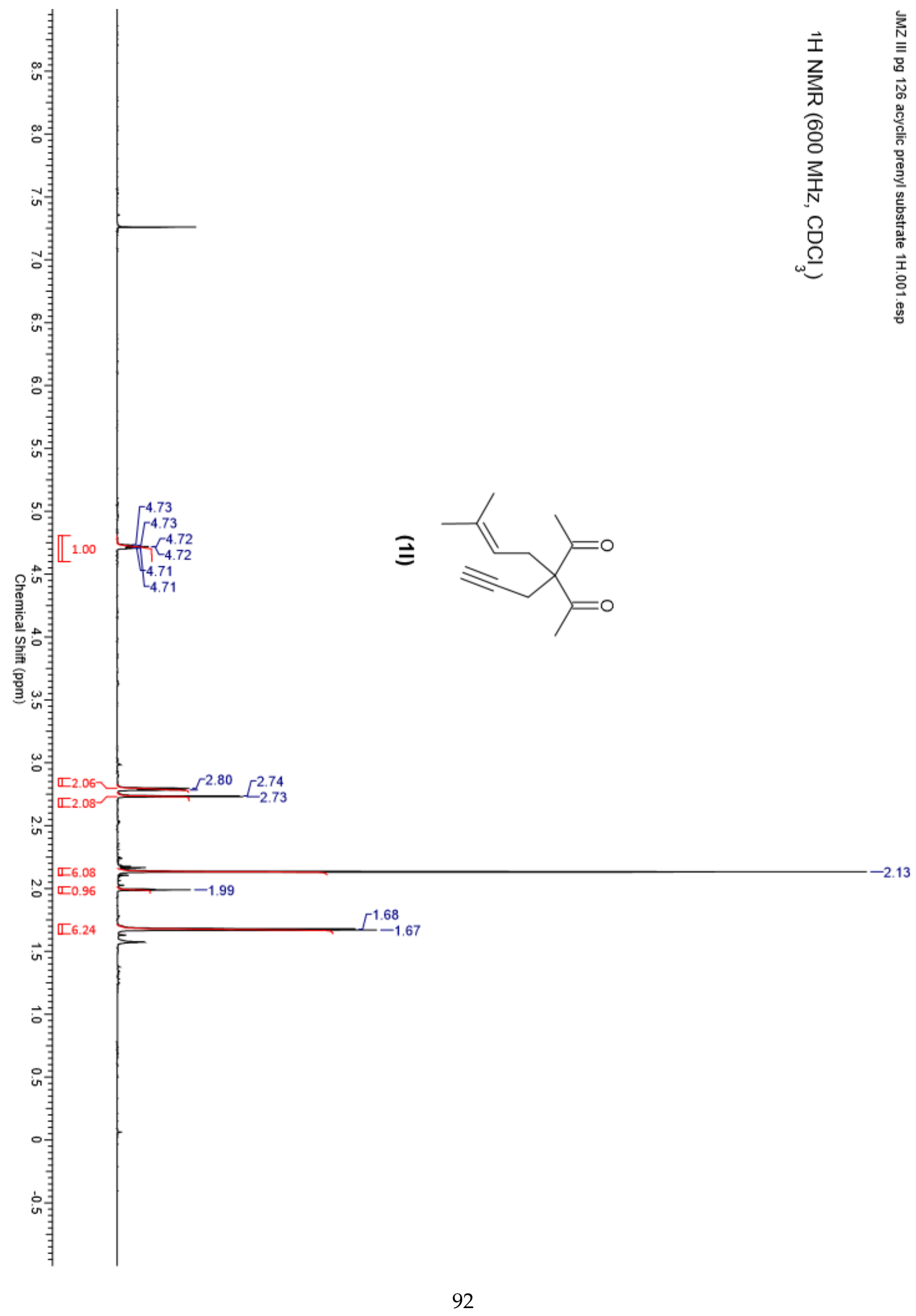




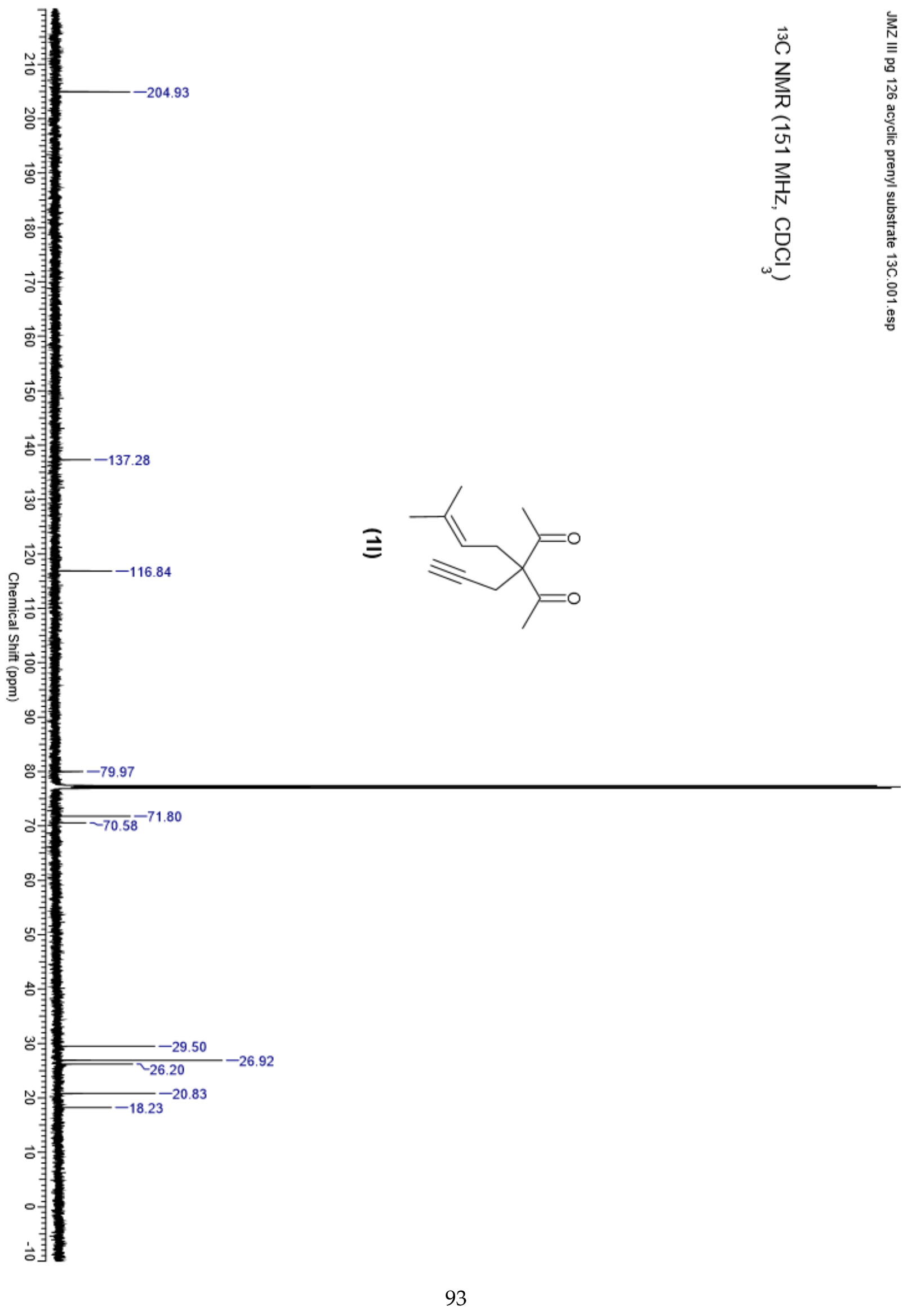




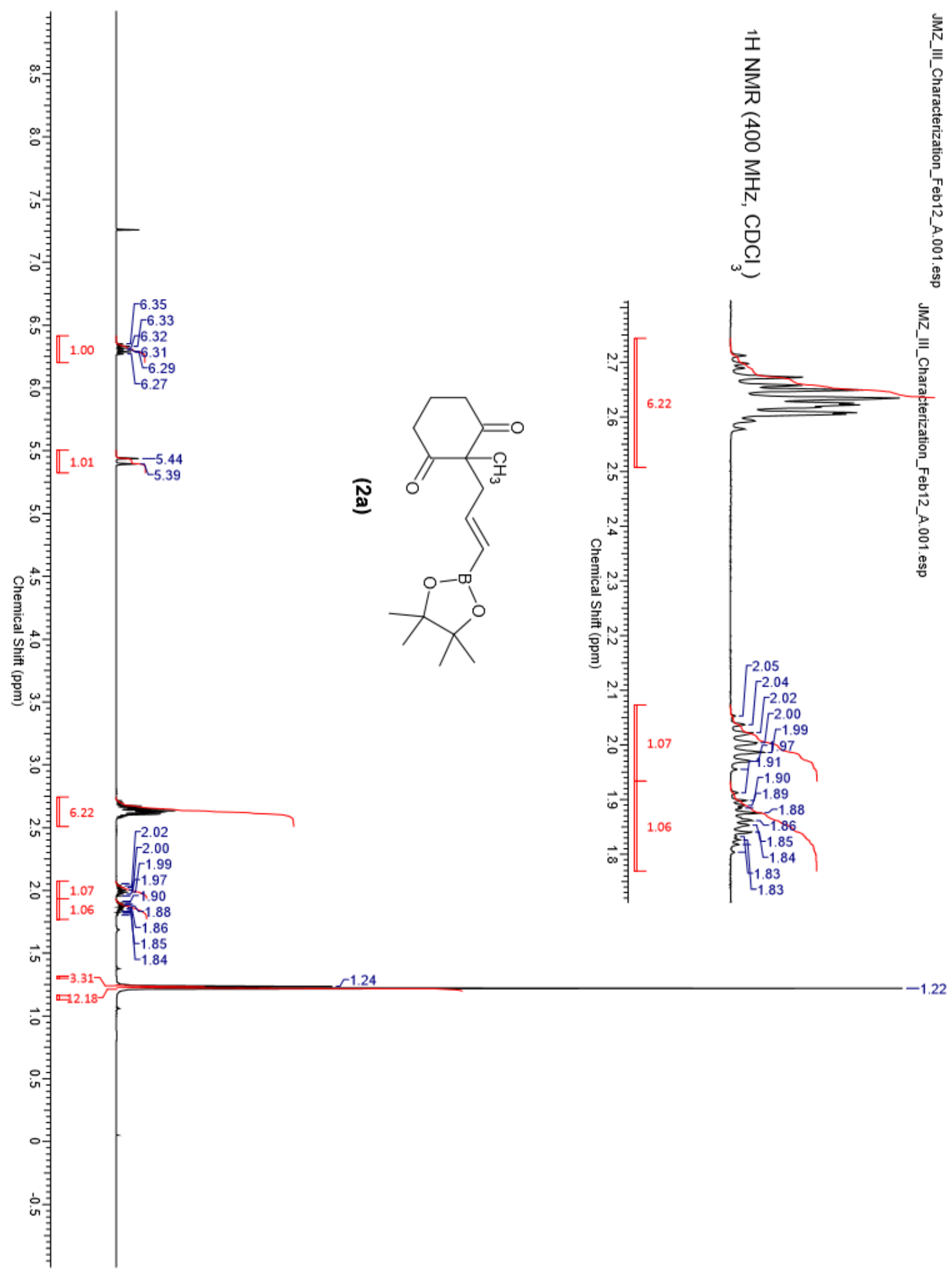




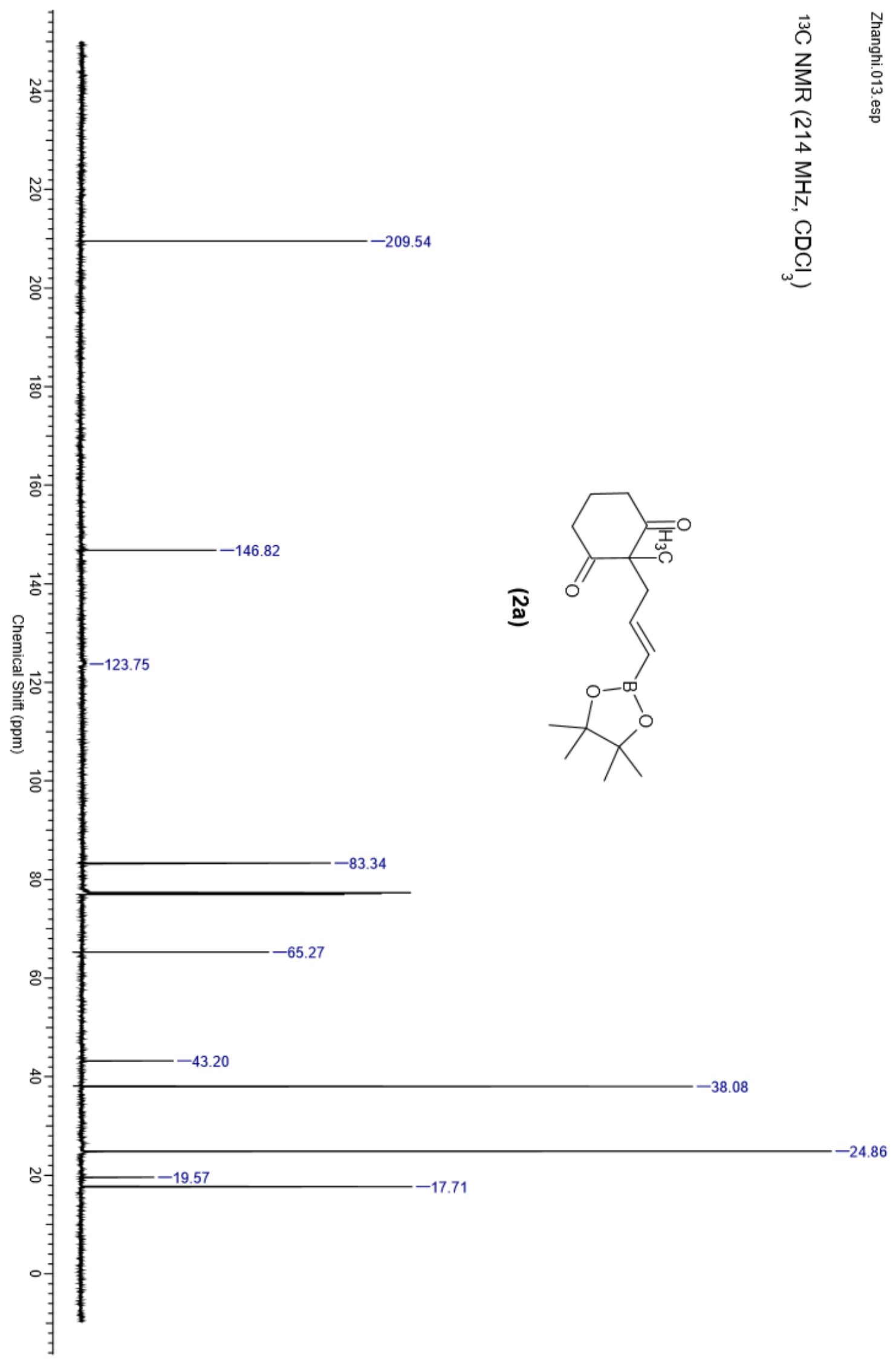




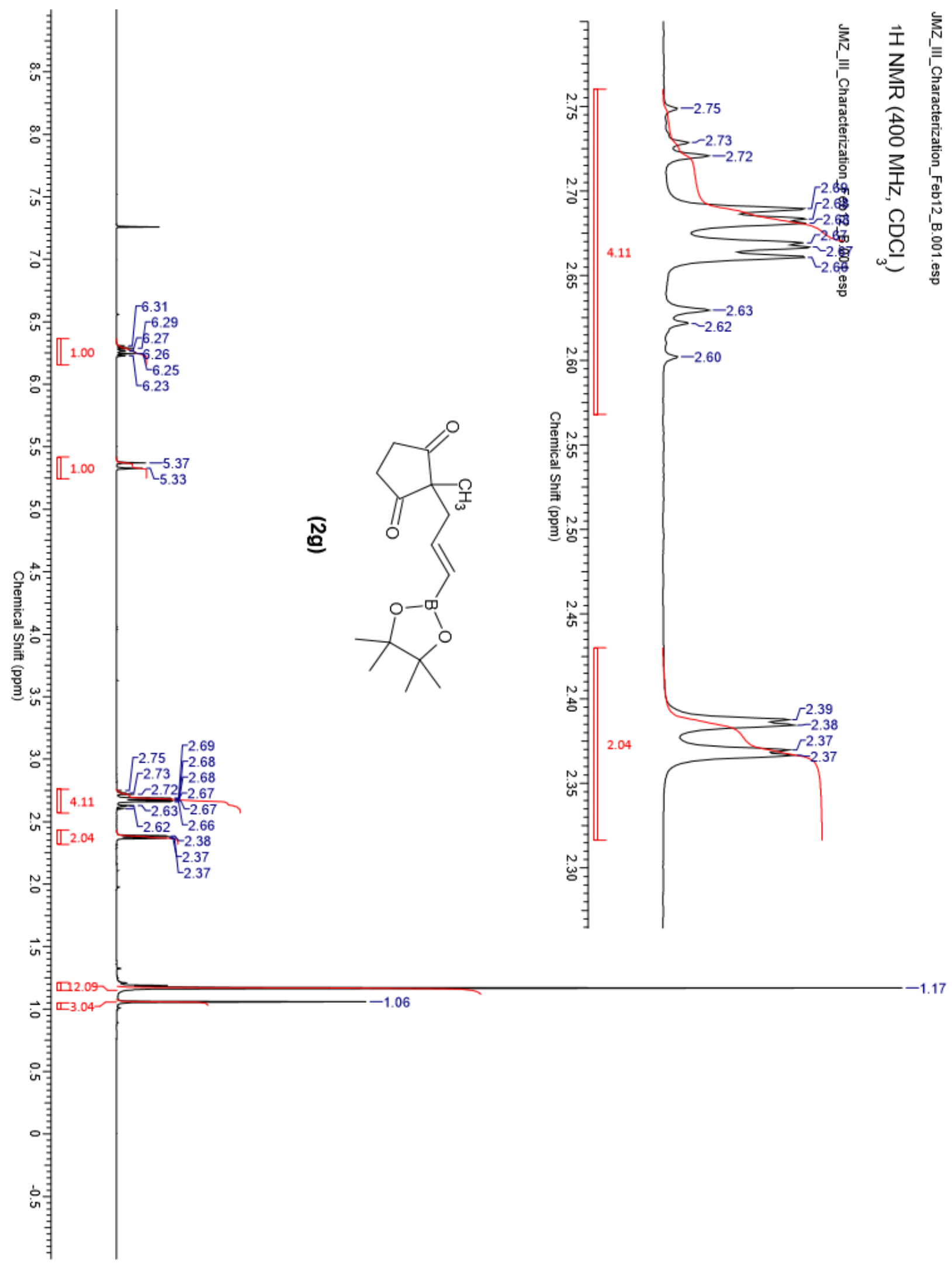




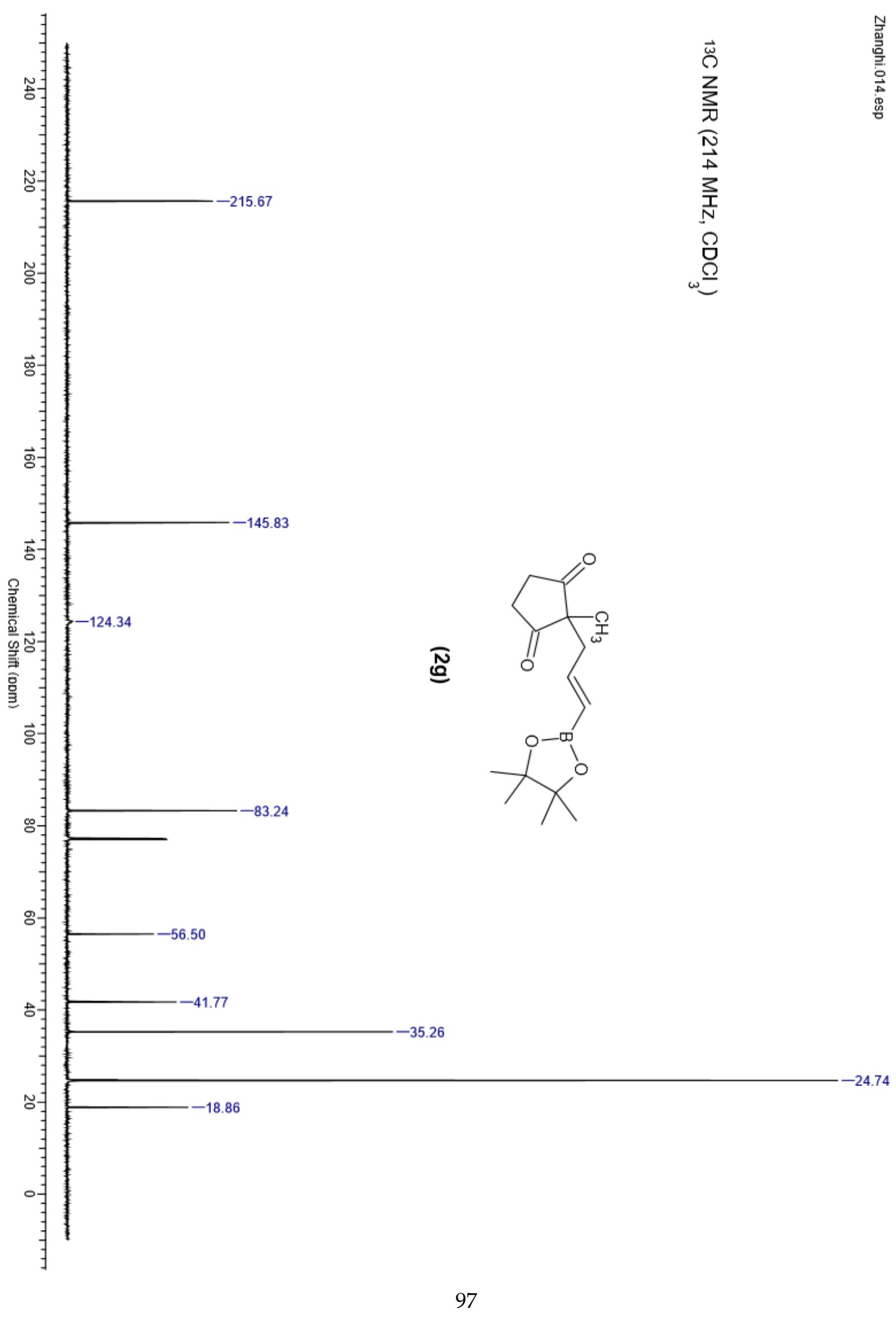




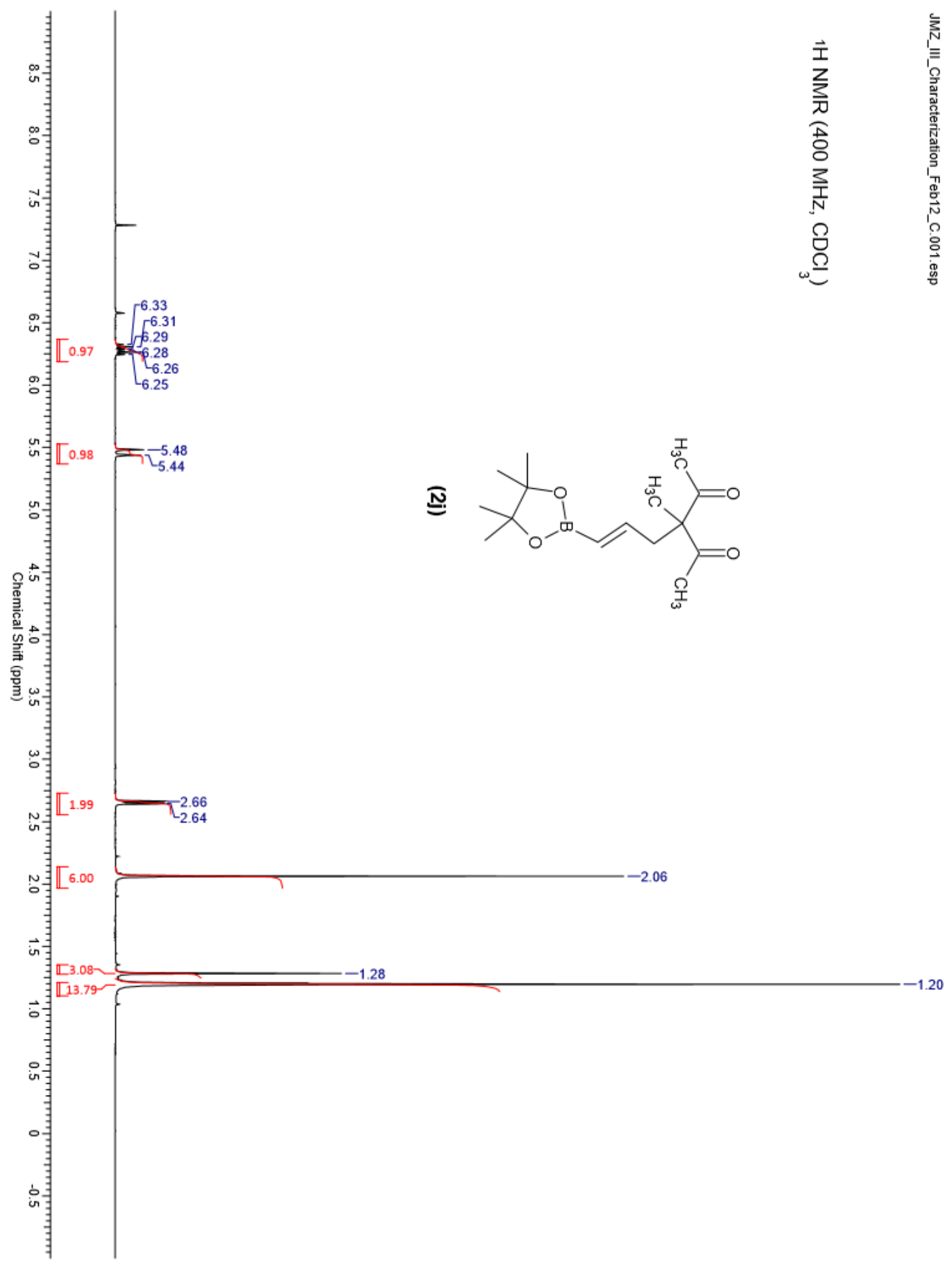




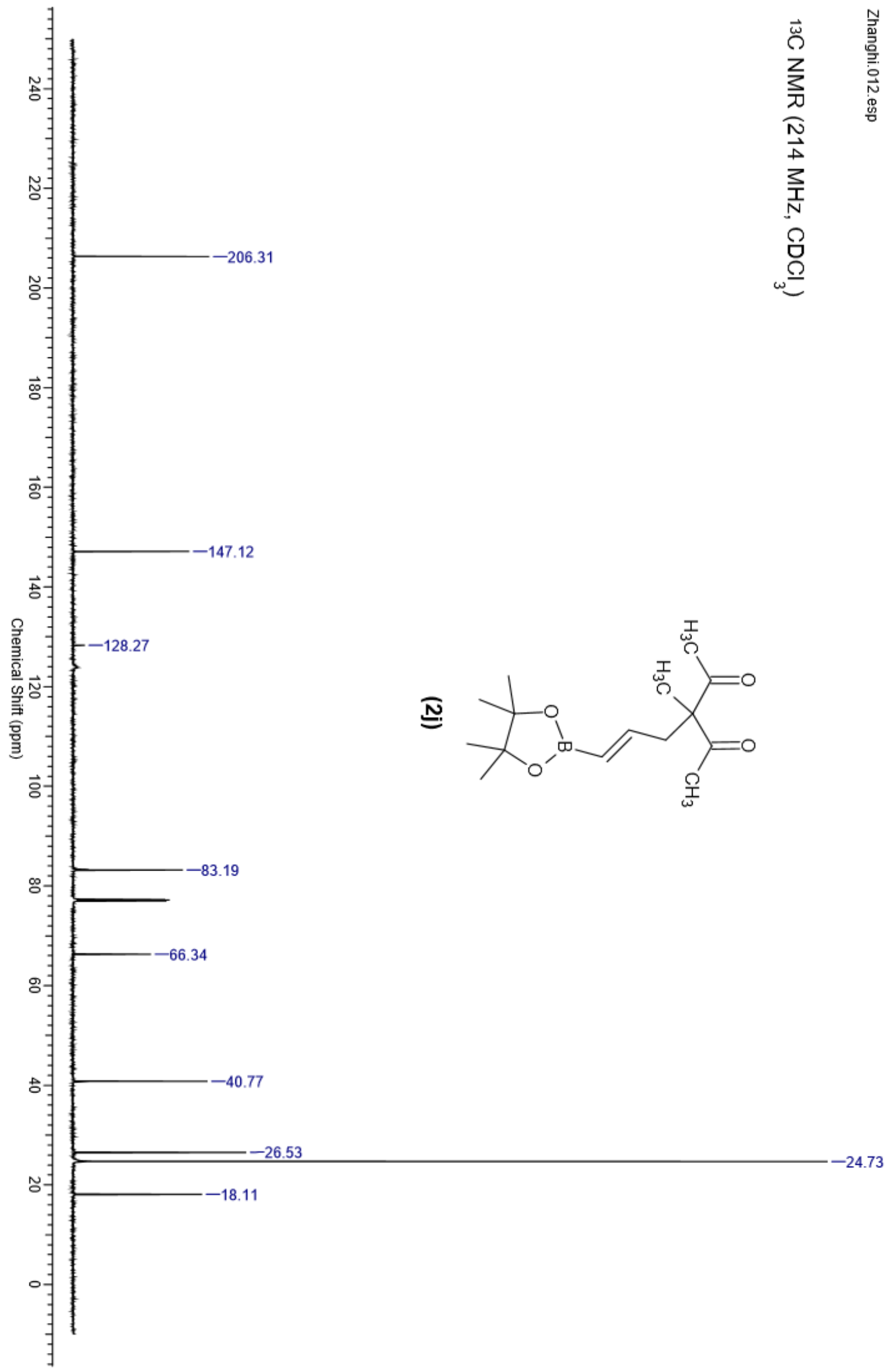


- Single-Crystal X-ray Data for (+)-(3b) (CCDC 1916345)

Table S4 Crystal data and structure refinement for (+)-(3b).

Identification code

dimedone-derived substrate

Empirical formula

$\mathrm{C}_{24} \mathrm{H}_{42} \mathrm{~B}_{2} \mathrm{O}_{6}$

Formula weight

448.25

Temperature/K

100.15

Crystal system

orthorhombic

Space group

$\mathrm{P} 2{ }_{1} 2_{1} 2_{1}$

$\mathrm{a} / \AA$

$12.2030(4)$

b/ $\AA$

$12.8185(4)$

$\mathrm{c} / \AA$

$17.0176(5)$

$\alpha /{ }^{\circ}$

90

$\beta /{ }^{\circ}$

$\gamma /{ }^{\circ}$

90

90

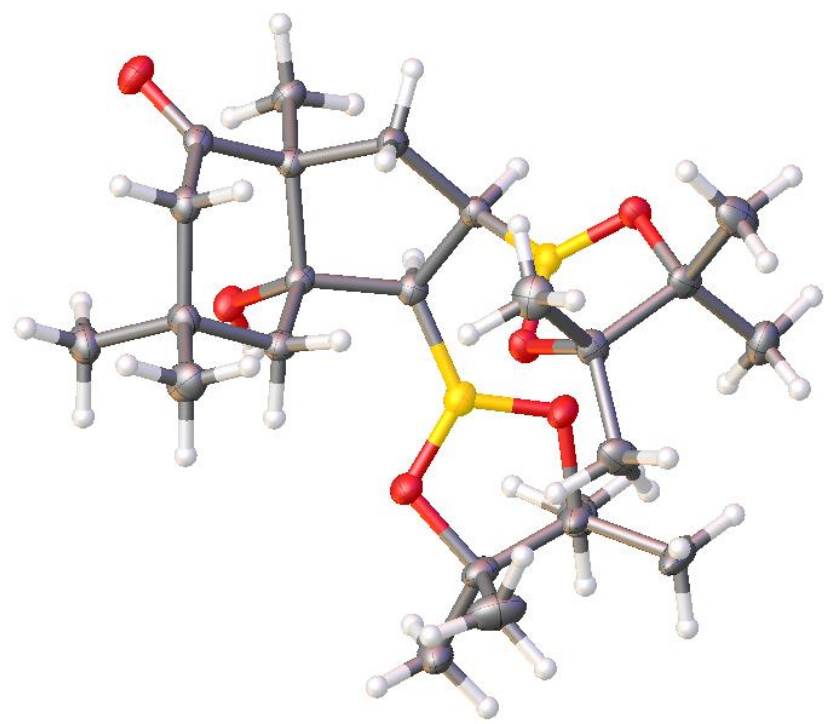

Volume $/ \AA^{3}$

2661.96(14)

$\mathrm{Z}$

4

$\rho_{\text {calc }} \mathrm{g} / \mathrm{cm}^{3}$

1.1183

$\mu / \mathrm{mm}^{-1}$

0.615

979.1

$\mathrm{F}(000)$

$0.4 \times 0.2 \times 0.1$

Crystal size $/ \mathrm{mm}^{3}$

$\mathrm{CuK} \alpha(\lambda=1.54178 \AA)$

Radiation

8.92 to 133.08

Index ranges

$-13 \leq \mathrm{h} \leq 14,-15 \leq \mathrm{k} \leq 14,-18 \leq 1 \leq 20$

Reflections collected

21235

Independent reflections

$4571\left[\mathrm{R}_{\text {int }}=0.0402, \mathrm{R}_{\text {sigma }}=0.0371\right]$

Data/restraints/parameters

$4571 / 0 / 301$

Goodness-of-fit on $\mathrm{F}^{2}$

1.034

Final $\mathrm{R}$ indexes $[\mathrm{I}>=2 \sigma(\mathrm{I})]$

$\mathrm{R}_{1}=0.0338, \mathrm{wR}_{2}=0.0692$

Final $\mathrm{R}$ indexes [all data]

Largest diff. peak/hole / e $\AA^{-3} 0.16 /-0.16$

Flack parameter

$0.09(16)$

Table S5 Fractional Atomic Coordinates $\left(\AA^{2} \times 10^{4}\right)$ and Equivalent Isotropic Displacement Parameters $\left(\AA^{2} \times 10^{3}\right)$ for dimedone-derived substrate. $U_{e q}$ is defined as 1/3 of of the trace of the orthogonalised $\mathrm{U}^{\mathrm{IJ}}$ tensor.

$\begin{array}{lrlll}\text { Atom } & \boldsymbol{x} & \boldsymbol{y} & \boldsymbol{z} & \mathbf{U}(\mathbf{e q}) \\ \text { O001 } & 2277.1(10) & 6997.8(9) & 5151.1(6) & 21.1(3) \\ \text { O002 } & 2235.4(9) & 8173.3(8) & 8676.8(6) & 19.9(3) \\ \text { O003 } & 3701.9(10) & 5584.6(8) & 6469.0(6) & 22.6(3) \\ \text { O004 } & 1970.4(9) & 6578.8(8) & 8110.4(6) & 20.0(3) \\ \text { O005 } & 4403.7(10) & 6743.6(9) & 7357.3(6) & 24.1(3)\end{array}$




$\begin{array}{lrrrr}\text { O006 } & -372.1(10) & 8501.0(9) & 5124.3(7) & 26.5(3) \\ \text { C00A } & 1706.8(14) & 9080.1(13) & 5503.2(10) & 22.0(4) \\ \text { C00B } & 2326.3(14) & 8134.4(12) & 7161.5(9) & 18.3(3) \\ \text { C00C } & 1262.0(14) & 6214.1(12) & 6232.5(9) & 19.3(4) \\ \text { C00D } & 1179.9(14) & 8179.7(12) & 5951.6(9) & 18.3(3) \\ \text { C00E } & 1606.3(14) & 6467.8(13) & 8925.6(9) & 21.1(4) \\ \text { C00F } & -565.7(14) & 7049.0(13) & 5981.3(9) & 22.1(4) \\ \text { C00G } & 4500.7(15) & 4996.7(13) & 6931.5(10) & 24.6(4) \\ \text { C00H } & 110.0(14) & 6040.4(13) & 5887.2(10) & 21.7(4) \\ \text { C00I } & 2164.6(15) & 7427.4(12) & 9325.6(9) & 21.5(4) \\ \text { C00J } & 1166.1(14) & 8437.4(13) & 6843.3(9) & 20.5(4) \\ \text { C00K } & 5180.0(15) & 5874.6(14) & 7331.4(10) & 25.7(4) \\ \text { C00L } & 146.3(15) & 5739.7(14) & 5014.8(10) & 27.5(4) \\ \text { C00M } & 361.2(15) & 6541.5(16) & 8907.6(11) & 31.1(4) \\ \text { C00N } & 1957.9(17) & 5416.3(13) & 9237.2(10) & 29.5(4) \\ \text { C00O } & 3335.2(15) & 7211.1(15) & 9581.9(10) & 29.7(4) \\ \text { C00P } & -449.7(16) & 5164.7(14) & 6348.4(11) & 31.3(4) \\ \text { C00Q } & 5142.9(16) & 4301.4(15) & 6378.5(11) & 33.4(5) \\ \text { C00R } & 1519.6(17) & 7924.5(14) & 9987.4(10) & 32.6(5) \\ \text { C00U } & 6138.9(16) & 6239.5(16) & 6838.2(12) & 35.8(5) \\ \text { C00V } & 3835.8(19) & 4340.1(15) & 7509.5(13) & 43.2(5) \\ \text { C00W } & 5543(2) & 5643.4(18) & 8164.3(10) & 45.1(6) \\ \text { C007 } & 32.6(14) & 7962.2(13) & 5641.3(9) & 19.3(4) \\ \text { C008 } & 2846.1(14) & 7449.5(12) & 6500.2(9) & 18.0(3) \\ \text { C009 } & 1900.3(13) & 7168.7(13) & 5936.7(9) & 17.4(3) \\ \text { B00S } & 2204.2(16) & 7612.9(14) & 7993.8(10) & 18.5(4) \\ \text { B00T } & 3640.2(16) & 6564.1(15) & 6783.9(10) & 19.2(4) \\ & & & & \end{array}$

Table S6 Anisotropic Displacement Parameters $\left(\AA^{2} \times 10^{3}\right)$ for dimedone-derived substrate. The Anisotropic displacement factor exponent takes the form: $2 \pi^{2}\left[h^{2} a^{* 2} U_{11}+2 h k a * b * U_{12}+\ldots\right]$.

\begin{tabular}{llllrrr} 
Atom & $\mathbf{U}_{\mathbf{1 1}}$ & $\mathbf{U}_{\mathbf{2 2}}$ & $\mathbf{U}_{\mathbf{3 3}}$ & \multicolumn{1}{c}{$\mathbf{U}_{\mathbf{1 2}}$} & \multicolumn{1}{c}{$\mathbf{U}_{\mathbf{1 3}}$} & \multicolumn{1}{c}{$\mathbf{U}_{\mathbf{2 3}}$} \\
O001 & $19.0(6)$ & $29.4(6)$ & $14.9(5)$ & $5.5(5)$ & $2.0(4)$ & $-0.5(5)$ \\
O002 & $25.2(6)$ & $18.1(6)$ & $16.4(5)$ & $-1.2(5)$ & $0.6(5)$ & $1.7(4)$ \\
O003 & $21.2(6)$ & $23.2(6)$ & $23.5(6)$ & $5.2(5)$ & $-4.2(5)$ & $-1.4(5)$ \\
O004 & $26.3(6)$ & $19.0(6)$ & $14.7(5)$ & $-2.3(5)$ & $1.5(5)$ & $1.5(5)$ \\
O005 & $24.2(6)$ & $28.2(6)$ & $19.8(6)$ & $10.1(6)$ & $-4.7(5)$ & $-3.6(5)$ \\
O006 & $24.3(7)$ & $32.3(7)$ & $23.0(6)$ & $3.7(6)$ & $-3.8(5)$ & $5.6(5)$ \\
C00A & $21.9(9)$ & $22.4(9)$ & $21.8(8)$ & $0.9(8)$ & $-1.4(7)$ & $4.4(7)$ \\
C00B & $19.1(9)$ & $17.3(8)$ & $18.5(8)$ & $-1.4(7)$ & $0.3(6)$ & $0.6(6)$
\end{tabular}




$\begin{array}{lrrrrrr}\text { C00C } & 18.7(9) & 19.7(8) & 19.5(8) & 2.1(7) & 0.7(7) & -0.9(7) \\ \text { C00D } & 17.7(8) & 19.8(8) & 17.5(8) & 2.1(7) & 0.2(7) & -1.6(6) \\ \text { C00E } & 24.3(9) & 23.5(9) & 15.4(8) & -2.5(8) & 3.7(7) & 1.2(7) \\ \text { C00F } & 19.1(9) & 26.5(9) & 20.6(8) & -0.7(8) & -0.9(7) & -2.0(7) \\ \text { C00G } & 26.1(10) & 25.4(9) & 22.3(9) & 10.4(8) & 0.1(8) & 2.2(7) \\ \text { C00H } & 21.0(9) & 21.1(8) & 22.9(9) & -1.8(8) & -1.1(7) & -1.6(7) \\ \text { C00I } & 28.3(10) & 20.7(8) & 15.5(8) & 0.3(8) & 1.9(7) & 3.3(7) \\ \text { C00J } & 24.8(9) & 20.5(8) & 16.3(8) & 3.4(8) & -0.6(7) & -0.6(7) \\ \text { C00K } & 26.5(10) & 30.5(10) & 20.1(9) & 15.2(8) & -4.7(7) & -6.1(7) \\ \text { C00L } & 24.7(10) & 30.8(10) & 27.1(9) & 0.1(8) & -4.1(8) & -6.9(8) \\ \text { C00M } & 24.2(10) & 36.4(10) & 32.8(10) & -5.4(9) & 3.7(8) & 2.0(8) \\ \text { C00N } & 42.3(12) & 22.4(9) & 23.8(9) & -1.9(9) & 5.9(8) & 3.4(7) \\ \text { C00O } & 30.6(11) & 35.1(10) & 23.3(9) & -3.4(9) & -7.1(8) & 4.8(8) \\ \text { C00P } & 28.2(11) & 28.1(10) & 37.6(10) & -5.0(8) & -4.3(9) & 3.1(8) \\ \text { C00Q } & 32.0(11) & 35.9(10) & 32.2(10) & 12.4(9) & -8.7(9) & -10.3(9) \\ \text { C00R } & 48.5(13) & 28.5(9) & 20.8(9) & -2.4(9) & 9.3(9) & -2.1(8) \\ \text { C00U } & 22.4(10) & 42.9(11) & 42.0(11) & 5.2(9) & -3.6(9) & -10.9(9) \\ \text { C00V } & 46.8(14) & 32.9(11) & 49.9(13) & 10.9(11) & 10.7(11) & 15.8(10) \\ \text { C00W } & 53.6(14) & 56.7(13) & 25.0(10) & 38.9(12) & -13.7(10) & -9.7(9) \\ \text { C007 } & 18.9(9) & 23.8(8) & 15.2(8) & 4.8(7) & 1.2(6) & -3.8(7) \\ \text { C008 } & 16.8(8) & 20.2(8) & 17.1(8) & -0.6(7) & 1.4(7) & 0.6(6) \\ \text { C009 } & 17.2(9) & 20.6(8) & 14.5(7) & 3.0(7) & 2.4(6) & 0.1(6) \\ \text { B00S } & 16.0(10) & 20.7(9) & 18.8(9) & -0.3(8) & -2.1(8) & -0.3(8) \\ \text { B00T } & 16.5(10) & 24.6(10) & 16.6(8) & -0.4(9) & 2.8(7) & 2.4(8)\end{array}$

Table S7 Bond Lengths for dimedone-derived substrate.

\begin{tabular}{lrll} 
Atom Atom & \multicolumn{1}{c}{ Length/A } & Atom Atom & \multicolumn{1}{c}{ Length/A } \\
O001 C009 & $1.4306(18)$ & C00D C009 & $1.566(2)$ \\
O002 C00I & $1.4632(18)$ & C00E C00I & $1.562(2)$ \\
O002 B00S & $1.367(2)$ & C00E C00M & $1.523(3)$ \\
O003 C00G & $1.462(2)$ & C00E C00N & $1.511(2)$ \\
O003 B00T & $1.367(2)$ & C00F C00H & $1.542(2)$ \\
O004 C00E & $1.4636(18)$ & C00F C007 & $1.496(2)$ \\
O004 B00S & $1.370(2)$ & C00G C00K & $1.555(2)$ \\
O005 C00K & $1.463(2)$ & C00G C00Q & $1.515(2)$ \\
O005 B00T & $1.368(2)$ & C00G C00V & $1.528(3)$ \\
O006 C007 & $1.223(2)$ & C00H C00L & $1.534(2)$ \\
C00A C00D & $1.526(2)$ & C00H C00P & $1.531(2)$ \\
C00B C00J & $1.565(2)$ & C00I C00O & $1.519(3)$ \\
C00B C008 & $1.562(2)$ & C00I C00R & $1.514(2)$
\end{tabular}




$\begin{array}{llll}\text { C00B B00S } & 1.573(2) & \text { C00K C00U } & 1.514(3) \\ \text { C00C C00H } & 1.540(2) & \text { C00K C00W } & 1.514(2) \\ \text { C00C C009 } & 1.535(2) & \text { C008 C009 } & 1.543(2) \\ \text { C00D C00J } & 1.553(2) & \text { C008 B00T } & 1.569(2) \\ \text { C00D C007 } & 1.522(2) & & \end{array}$

Table S8 Bond Angles for dimedone-derived substrate.

\begin{tabular}{|c|c|c|c|}
\hline Atom Atom Atom & Angle $/^{\circ}$ & Atom Atom Atom & Angle ${ }^{\circ}$ \\
\hline B00S O002 C00I & $107.26(12)$ & $\mathrm{COOP} \mathrm{COOHCOOL}$ & $108.95(14)$ \\
\hline B00T O003 C00G & $107.40(13)$ & C00E C00I O002 & $102.20(12)$ \\
\hline B00S O004 C00E & $107.13(12)$ & C00O C00I O002 & $106.28(14)$ \\
\hline B00T O005 C00K & $106.94(13)$ & COOO COOI COOE & $113.05(14)$ \\
\hline C008 C00B C00J & $104.93(12)$ & C00R C00I O002 & $108.47(13)$ \\
\hline B00S COOB COOJ & 109.35 (13) & COOR COOI COOE & $115.38(15)$ \\
\hline B00S C00B C008 & $116.64(13)$ & COOR COOI COOO & $110.61(15)$ \\
\hline $\mathrm{CO09} \mathrm{C} 00 \mathrm{C} \mathrm{C} 00 \mathrm{H}$ & $116.96(14)$ & C00D C00J C00B & $105.99(13)$ \\
\hline COOJ COODC00A & $109.41(13)$ & C00G C00K O005 & $102.65(13)$ \\
\hline C007 C00DC00A & $110.65(13)$ & C00U C00K O005 & $106.38(14)$ \\
\hline C007 C00DC00J & $111.59(13)$ & COOU C00K C00G & $113.14(14)$ \\
\hline C009 C00DC00A & $112.42(13)$ & C00W C00K O005 & $108.09(13)$ \\
\hline C009 C00DC00J & $101.41(12)$ & C00W C00K C00G & $115.10(16)$ \\
\hline C009 C00DC007 & 111.05 (13) & C00W C00K C00U & $110.67(17)$ \\
\hline COOI COOE O004 & $101.78(12)$ & C00D C007 O006 & $121.17(15)$ \\
\hline C00MC00E O004 & $106.13(13)$ & C00F C007 O006 & $121.55(15)$ \\
\hline COOM COOE COOI & $113.27(15)$ & C00F C007 C00D & $117.26(14)$ \\
\hline C00N C00E O004 & $109.47(14)$ & C009 C008 C00B & $105.97(13)$ \\
\hline COON COOE COOI & $115.20(14)$ & B00T C008 C00B & $115.84(13)$ \\
\hline COON COOE COOM & $110.23(16)$ & B00T C008 C009 & $118.99(13)$ \\
\hline $\mathrm{C} 007 \mathrm{C} 00 \mathrm{~F} \mathrm{C} 00 \mathrm{H}$ & $110.79(14)$ & C00C C009 O001 & $110.32(13)$ \\
\hline C00K C00GO003 & $102.60(12)$ & C00D C009 O001 & $108.80(12)$ \\
\hline C00Q C00GO003 & $108.29(13)$ & C00D C009 C00C & $111.68(13)$ \\
\hline C00Q C00GC00K & $114.97(15)$ & C008 C009 O001 & $112.09(13)$ \\
\hline C00V C00GO003 & $106.05(15)$ & C008 C009 C00C & $111.20(13)$ \\
\hline C00V C00GC00K & $113.59(15)$ & C008 C009 C00D & $102.52(12)$ \\
\hline C00V C00GC00Q & $110.52(15)$ & O004 B00S O002 & $113.02(14)$ \\
\hline $\mathrm{COOF} \mathrm{COOHCOOC}$ & $109.11(13)$ & C00B B00S O002 & $122.66(14)$ \\
\hline $\mathrm{COOL} \mathrm{COOHCOOC}$ & $112.28(14)$ & C00B B00S O004 & $124.13(14)$ \\
\hline $\mathrm{COOL} \mathrm{COOHCOOF}$ & $109.06(14)$ & О005 В00Т О003 & $113.35(15)$ \\
\hline $\mathrm{COOP} \mathrm{COOHCOOC}$ & $108.53(14)$ & С008 В00Т О003 & $125.30(15)$ \\
\hline COOP COOHCOOF & $108.85(14)$ & C008 В00T O005 & $121.23(15)$ \\
\hline
\end{tabular}


Table S9 Hydrogen Atom Coordinates $\left(\AA \times 10^{4}\right)$ and Isotropic Displacement Parameters $\left(\AA^{2} \times 10^{3}\right)$ for dimedone-derived substrate.

\begin{tabular}{|c|c|c|c|c|}
\hline Atom & $x$ & $y$ & $z$ & $\mathbf{U}(\mathbf{e q})$ \\
\hline H001 & $2902(7)$ & $6723(14)$ & $5163.1(6)$ & $31.6(4)$ \\
\hline $\mathrm{HOOa}$ & $1841(8)$ & $8868(3)$ & $4959(2)$ & $33.0(6)$ \\
\hline $\mathrm{H} 00 \mathrm{~b}$ & $1214(4)$ & $9684(3)$ & $5510(6)$ & $33.0(6)$ \\
\hline $\mathrm{HOOc}$ & $2403(5)$ & $9267(6)$ & $5753(4)$ & $33.0(6)$ \\
\hline HOOd & $2771.4(14)$ & $8785.0(12)$ & $7218.6(9)$ & $22.0(4)$ \\
\hline $\mathrm{HOOe}$ & $1190.9(14)$ & $6272.3(12)$ & $6810.3(9)$ & $23.2(4)$ \\
\hline HOOf & $1706.2(14)$ & $5584.5(12)$ & $6122.6(9)$ & $23.2(4)$ \\
\hline $\mathrm{H} 00 \mathrm{~g}$ & $-1279.6(14)$ & $6967.0(13)$ & $5711.9(9)$ & $26.5(4)$ \\
\hline $\mathrm{HOOh}$ & $-710.0(14)$ & $7175.9(13)$ & $6545.7(9)$ & $26.5(4)$ \\
\hline H0Oi & $589.6(14)$ & $8030.1(13)$ & $7114.3(9)$ & $24.6(4)$ \\
\hline $\mathrm{H} 00 \mathrm{j}$ & $1023.2(14)$ & $9189.3(13)$ & $6927.7(9)$ & $24.6(4)$ \\
\hline $\mathrm{H} 00 \mathrm{k}$ & $484(9)$ & $6306(4)$ & $4712.9(14)$ & $41.3(6)$ \\
\hline H001 & $579(8)$ & $5102(6)$ & $4950.5(13)$ & $41.3(6)$ \\
\hline $\mathrm{H} 00 \mathrm{~m}$ & $-600.8(17)$ & $5620(9)$ & $4824(2)$ & $41.3(6)$ \\
\hline HOOn & $143.5(15)$ & $7234(4)$ & $8721(7)$ & $46.7(7)$ \\
\hline $\mathrm{HOOo}$ & $68.1(16)$ & $6008(7)$ & $8553(6)$ & $46.7(7)$ \\
\hline $\mathrm{H} 00 \mathrm{p}$ & $70.7(16)$ & $6430(10)$ & $9437.8(18)$ & $46.7(7)$ \\
\hline $\mathrm{H} 00 \mathrm{q}$ & $1593(8)$ & $4863.6(13)$ & $8937(5)$ & $44.2(7)$ \\
\hline $\mathrm{HOOr}$ & $2754(2)$ & $5344(4)$ & $9184(7)$ & $44.2(7)$ \\
\hline $\mathrm{H} 00 \mathrm{~s}$ & $1755(9)$ & $5359(4)$ & $9793(2)$ & $44.2(7)$ \\
\hline $\mathrm{H} 00 \mathrm{t}$ & $3742(3)$ & $6898(9)$ & $9145(2)$ & $44.5(6)$ \\
\hline $\mathrm{HOOu}$ & $3687(3)$ & $7867(2)$ & $9737(7)$ & $44.5(6)$ \\
\hline $\mathrm{H} 00 \mathrm{v}$ & $3331.3(16)$ & $6729(7)$ & $10029(5)$ & $44.5(6)$ \\
\hline $\mathrm{H} 00 \mathrm{w}$ & $-27(6)$ & $4519(3)$ & $6291(6)$ & $47.0(7)$ \\
\hline $\mathrm{H} 00 \mathrm{x}$ & $-488(10)$ & $5356(5)$ & $6905.2(17)$ & $47.0(7)$ \\
\hline $\mathrm{HOOy}$ & $-1192(4)$ & $5058(7)$ & $6144(5)$ & $47.0(7)$ \\
\hline $\mathrm{H}$ & $5749(7)$ & $3974(8)$ & $6665(2)$ & $50.1(7)$ \\
\hline $\mathrm{H} 00 \mathrm{z}$ & $4659(3)$ & $3759(6)$ & $6167(6)$ & $50.1(7)$ \\
\hline $\mathrm{Ha}$ & $5436(9)$ & $4721(2)$ & $5945(4)$ & $50.1(7)$ \\
\hline $\mathrm{HOO}$ & $1917(5)$ & $8535(6)$ & $10184(5)$ & $48.9(7)$ \\
\hline $\mathrm{Hb}$ & $799(4)$ & $8141(9)$ & $9792(2)$ & $48.9(7)$ \\
\hline $\mathrm{Hc}$ & $1425(9)$ & $7419(4)$ & $10414(3)$ & $48.9(7)$ \\
\hline H0aa & $5880(2)$ & $6428(10)$ & $6312(3)$ & $53.6(7)$ \\
\hline $\mathrm{Hd}$ & $6478(7)$ & $6849(6)$ & $7087(4)$ & $53.6(7)$ \\
\hline $\mathrm{He}$ & $6680(5)$ & $5677(4)$ & $6797(6)$ & $53.6(7)$ \\
\hline H1aa & $3400(9)$ & $4800.5(16)$ & $7847(6)$ & $64.8(8)$ \\
\hline Hf & 3347 (9) & $3874(8)$ & $7217.6(13)$ & $64.8(8)$ \\
\hline
\end{tabular}




$\begin{array}{lrrrr}\mathrm{Hg} & 4334.4(19) & 3925(9) & 7835(6) & 64.8(8) \\ \mathrm{H} 2 \mathrm{aa} & 5932(11) & 6250(5) & 8378(3) & 67.7(9) \\ \mathrm{Hh} & 4900(2) & 5493(11) & 8490(2) & 67.7(9) \\ \mathrm{Hi} & 6033(10) & 5038(8) & 8164.0(15) & 67.7(9) \\ \mathrm{H} 008 & 3320.7(14) & 7939.5(12) & 6194.7(9) & 21.6(4)\end{array}$

Experimental

Single crystals of $\mathrm{C}_{24} \mathrm{H}_{42} \mathrm{~B}_{2} \mathrm{O}_{6}(+)-3 \mathbf{b}$ were grown from hexanes/isopropyl alcohol cooled to $-20{ }^{\circ} \mathrm{C}$. A suitable crystal was selected and mounted on a Bruker APEX-II CCD' diffractometer. The crystal was kept at $100.15 \mathrm{~K}$ during data collection. Using Olex2 [1], the structure was solved with the olex2.solve [2] structure solution program using Charge Flipping and refined with the olex2.refine [3] refinement package using Gauss-Newton minimisation.

1. Dolomanov, O.V., Bourhis, L.J., Gildea, R.J, Howard, J.A.K. \& Puschmann, H. (2009), J. Appl. Cryst. 42, 339-341.

2. Bourhis, L.J., Dolomanov, O.V., Gildea, R.J., Howard, J.A.K., Puschmann, H. (2015). Acta Cryst. A71, 59-75.

3. Bourhis, L.J., Dolomanov, O.V., Gildea, R.J., Howard, J.A.K., Puschmann, H. (2015). Acta Cryst. A71, $59-75$.

\section{Crystal structure determination of [dimedone-derived substrate]}

Crystal Data for $\mathrm{C}_{24} \mathrm{H}_{42} \mathrm{~B}_{2} \mathrm{O}_{6}(+)-3 \mathbf{b}(M=448.25 \mathrm{~g} / \mathrm{mol})$ : orthorhombic, space group $\mathrm{P} 22_{1} 2_{1} 2_{1}$ (no. 19), $a=$ 12.2030(4) $, b=12.8185(4) \AA, c=17.0176(5) \AA, V=2661.96(14) \AA^{3}, Z=4, T=100.15 \mathrm{~K}, \mu(\mathrm{Cu} \mathrm{K \alpha})=0.615 \mathrm{~mm}^{-}$ ${ }^{1}$, Dcalc $=1.1183 \mathrm{~g} / \mathrm{cm}^{3}, 21235$ reflections measured $\left(8.92^{\circ} \leq 2 \Theta \leq 133.08^{\circ}\right), 4571$ unique $\left(R_{\text {int }}=0.0402, \mathrm{R}_{\text {sigma }}=\right.$ 0.0371 ) which were used in all calculations. The final $R_{1}$ was 0.0338 (I $\left.>=2 \mathrm{u}(\mathrm{I})\right)$ and $w R_{2}$ was 0.0720 (all data).

\section{Refinement model description}

Details:

Number of restraints - 0, number of constraints - 59 .

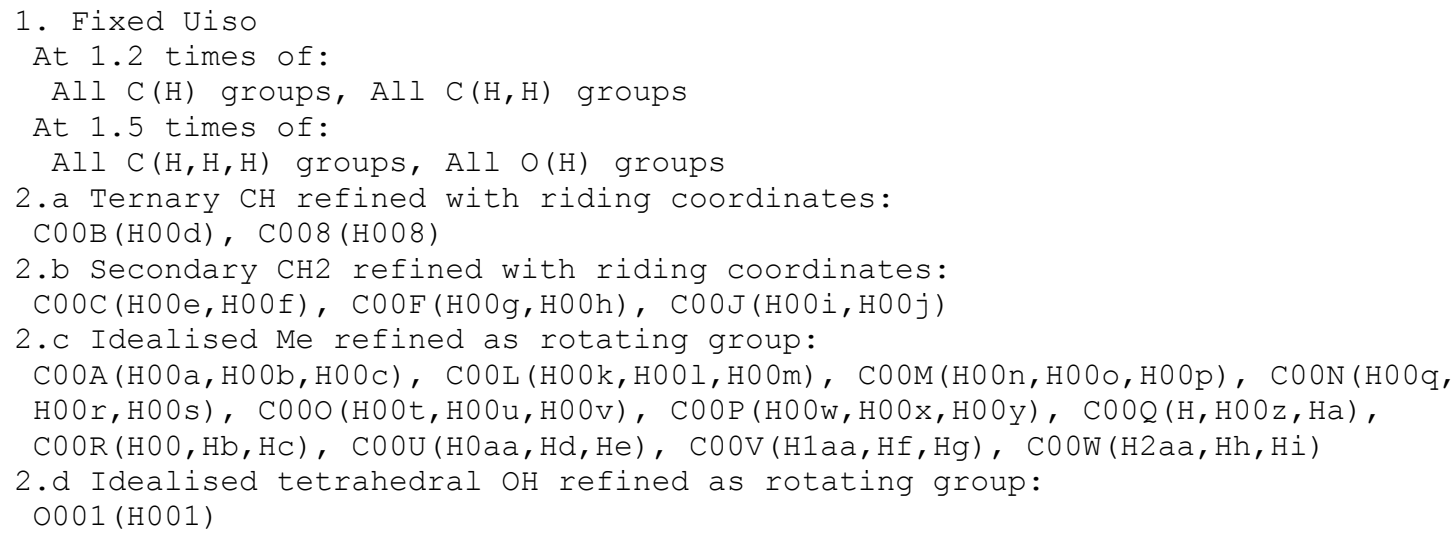


UNC CHAPEL HILL DEPARTMENT OF CHEMISTRY (CCDC 1916346)

X-ray Core Laboratory

Report No. 19003

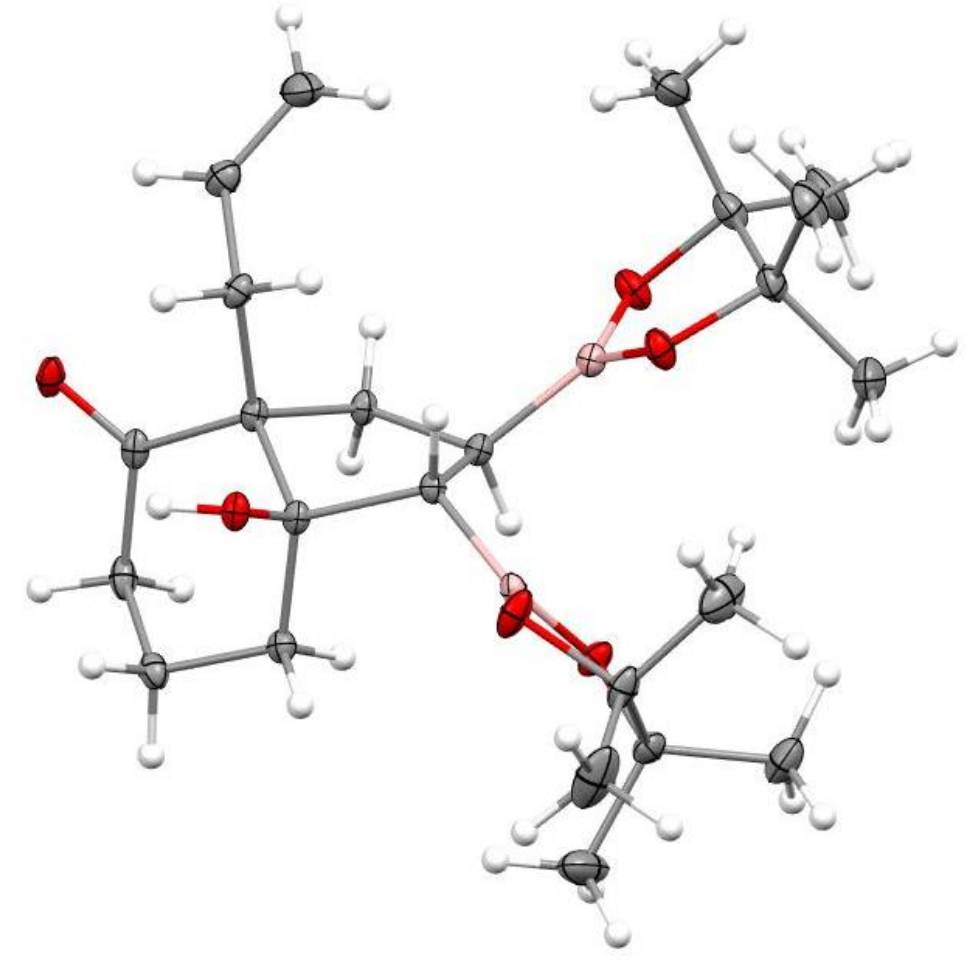

$\mathrm{C}_{24} \mathrm{H}_{40} \mathrm{~B}_{2} \mathrm{O}_{6}$

Prepared for

Joseph Zanghi and Prof. S. Meek

by

C. Chen

January 31, 2019 
The sample was submitted by Joseph Zanghi (research group of Meek, Department of Chemistry, the University of North Carolina at Chapel Hill). A colorless crystal (approximate dimensions $0.200 \times 0.200 \times 0.200 \mathrm{~mm}^{3}$ ) was placed onto the tip of MiTeGen and mounted on a Bruker SMART Apex II diffractometer and measured at $150 \mathrm{~K}$.

\section{Data collection}

A preliminary set of cell constants was calculated from reflections harvested from three sets of 12 frames. These initial sets of frames were oriented such that orthogonal wedges of reciprocal space were surveyed. This produced initial orientation matrices determined from 161 reflections. The data collection was carried out using $\mathrm{Cu} \mathrm{K} \alpha$ radiation (graphite monochromator) with a frame time of 30 seconds and a detector distance of $4.0 \mathrm{~cm}$. A randomly oriented region of reciprocal space was surveyed to achieve complete data with a redundancy of 4 . Sections of frames were collected with $0.50^{\circ}$ steps in $\omega$ and $\phi$ scans. Data to a resolution of $0.84 \AA$ were considered in the reduction. Final cell constants were calculated from the xyz centroids of 9943 strong reflections from the actual data collection after integration (SAINT). ${ }^{1}$ The intensity data were corrected for absorption (SADABS). ${ }^{2}$ Please refer to Table S10 for additional crystal and refinement information.

\section{Structure solution and refinement}

The space group $\mathrm{P} 2_{1} / \mathrm{n}$ was determined based on intensity statistics and systematic absences. The structure was solved using Superflip ${ }^{3}$ and refined (full-matrix-least squares) using the Oxford University Crystals for Windows system. ${ }^{4}$ The charge-flipping solution provided most non-hydrogen atoms from the E-map. Full-matrix least squares / difference Fourier cycles were performed, which located the remaining non-hydrogen atoms. All non-hydrogen atoms were refined with anisotropic displacement parameters. The hydrogen atoms were generated geometrically and the positions were subsequently refined. The final full matrix least squares refinement converged to $\mathrm{R} 1=0.0390$ and $\mathrm{wR} 2=0.1030\left(\mathrm{~F}^{2}\right.$, all data $)$.

\section{Structure description}

The structure was found with two tetramethyl dioxaborolane in trans confirmation.

${ }^{1}$ SAINT, Bruker Analytical X-Ray Systems, Madison, WI, current version.

${ }^{2}$ An empirical correction for absorption anisotropy, R. Blessing, Acta Cryst. A51, 33 - 38 (1995).

${ }^{3}$ Palatinus L., Chapuis G. (2007): Superflip - a computer program for the solution of crystal structures by charge flipping in arbitrary dimensions. J. Appl. Cryst. 40, 786-790.

${ }^{4}$ Betteridge, P. W.; Carruthers, J. R.; Cooper, R. I.; Prout, K.; Watkin, D. J. J. Appl. Cryst. 2003, 36, 1487. 


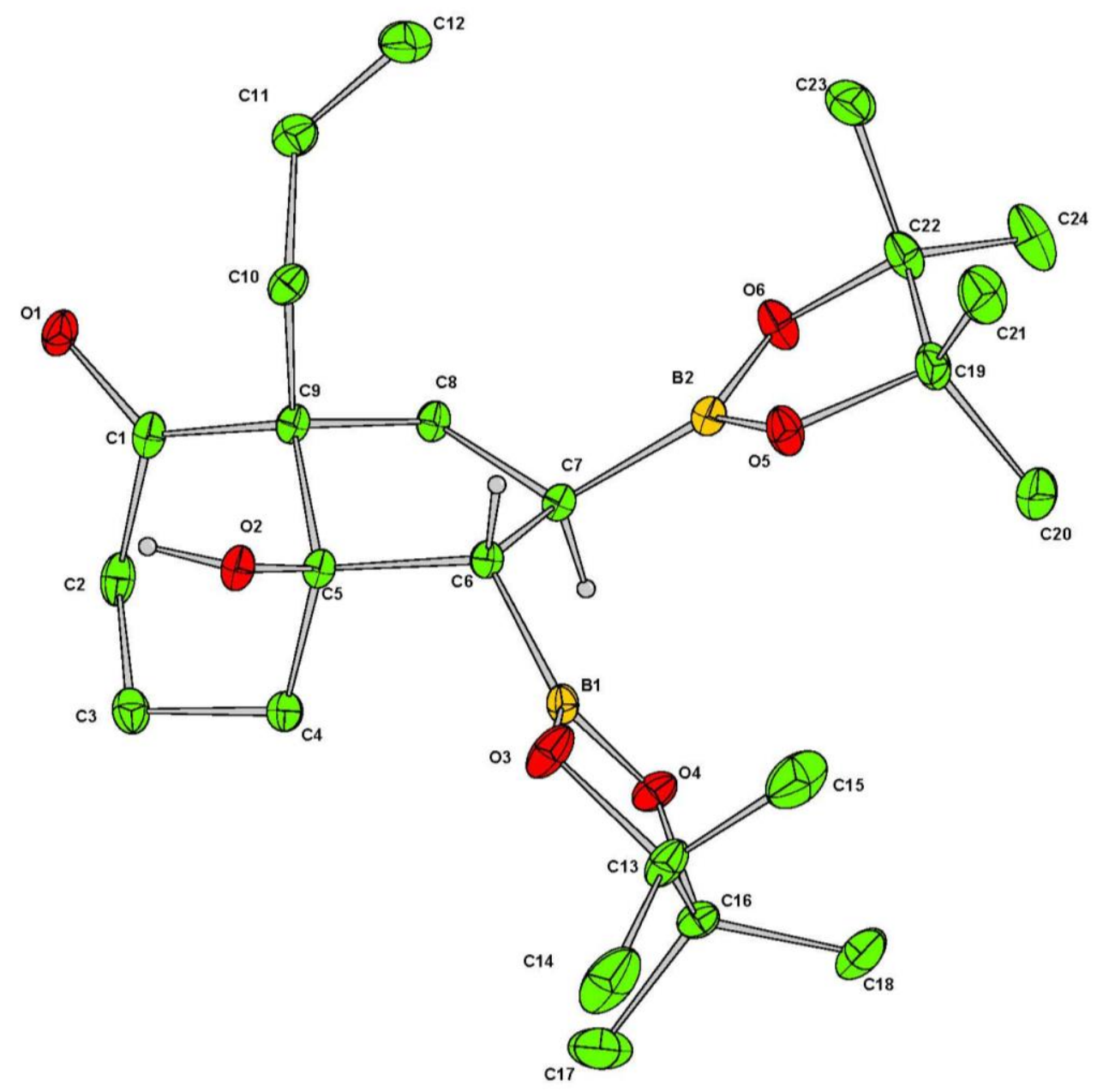

Molecular structure with labels on the asymmetric unit. Hydrogen atoms on the O2, C6, and C7 were made visible for ease of viewing.

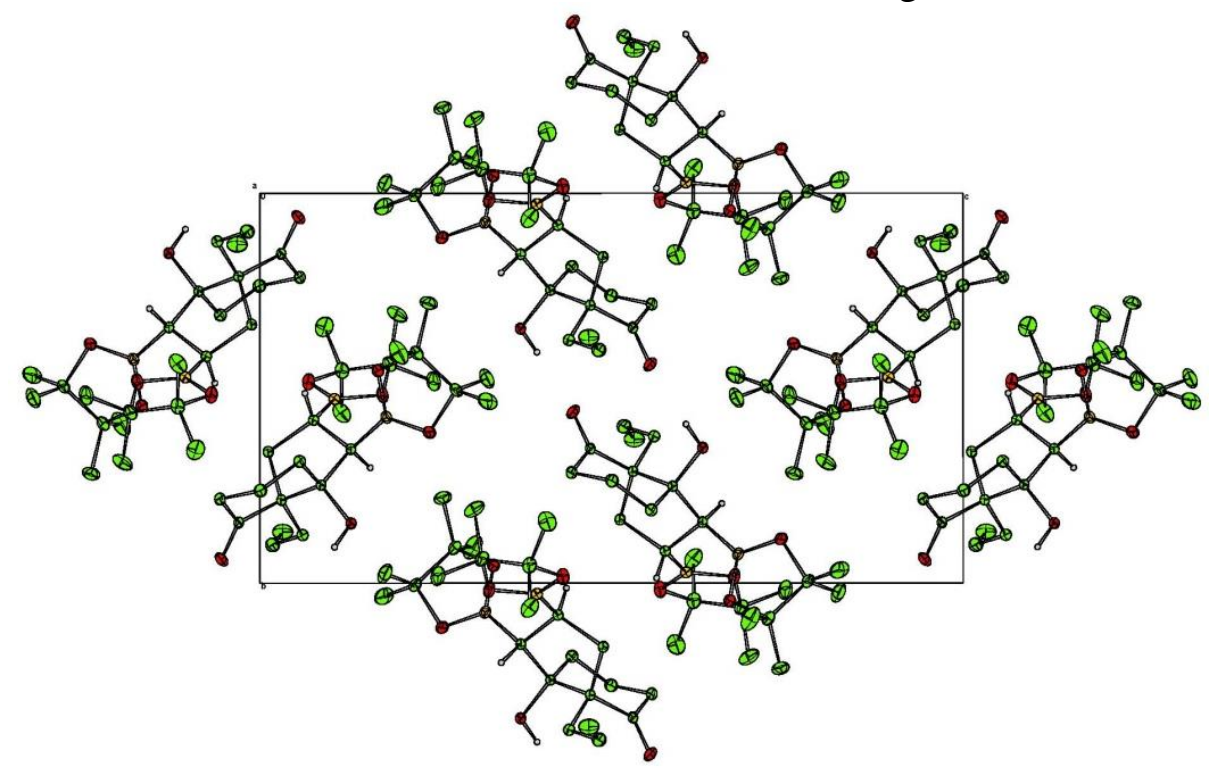

Cell plot, viewed along a- axis 


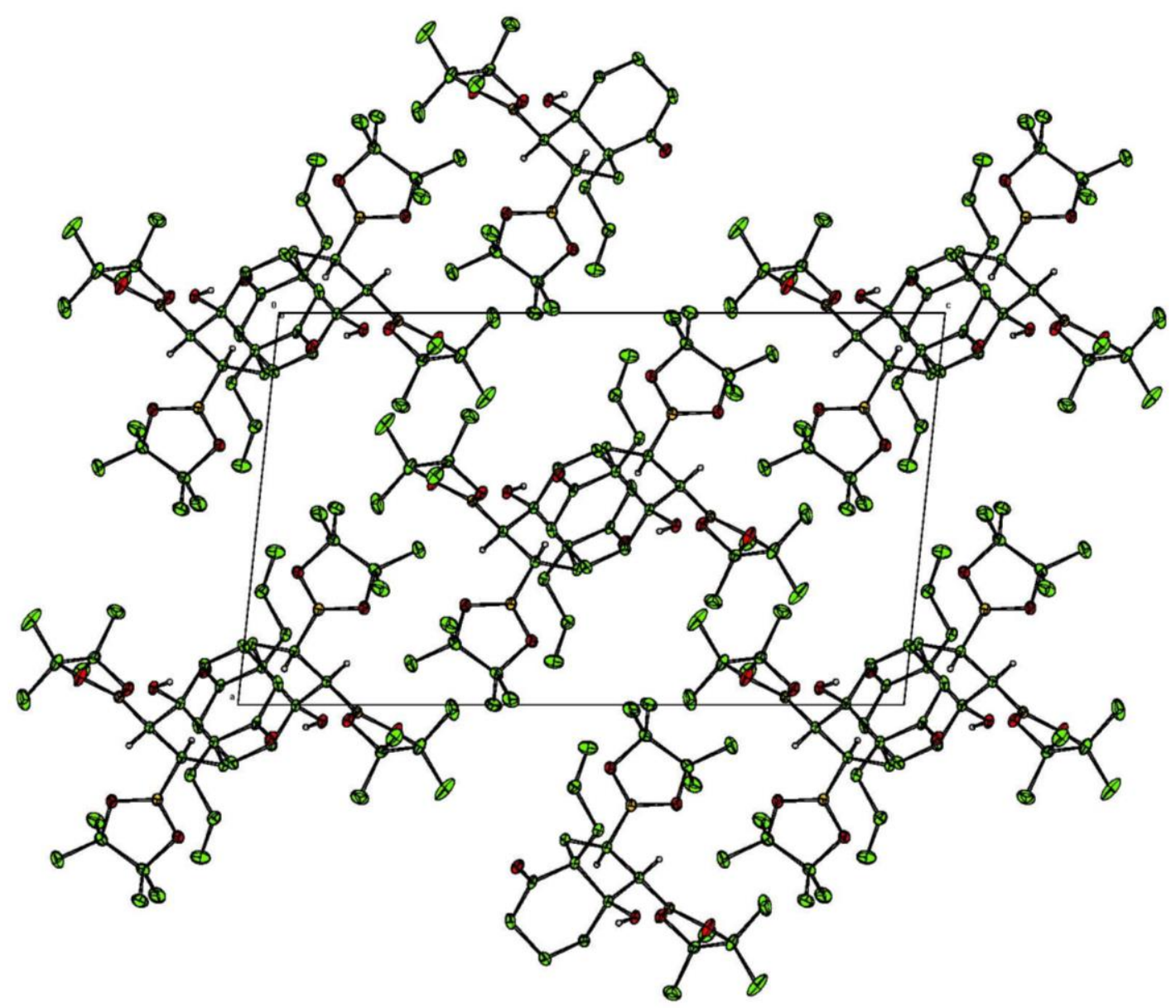

Cell plot, viewed along b- axis

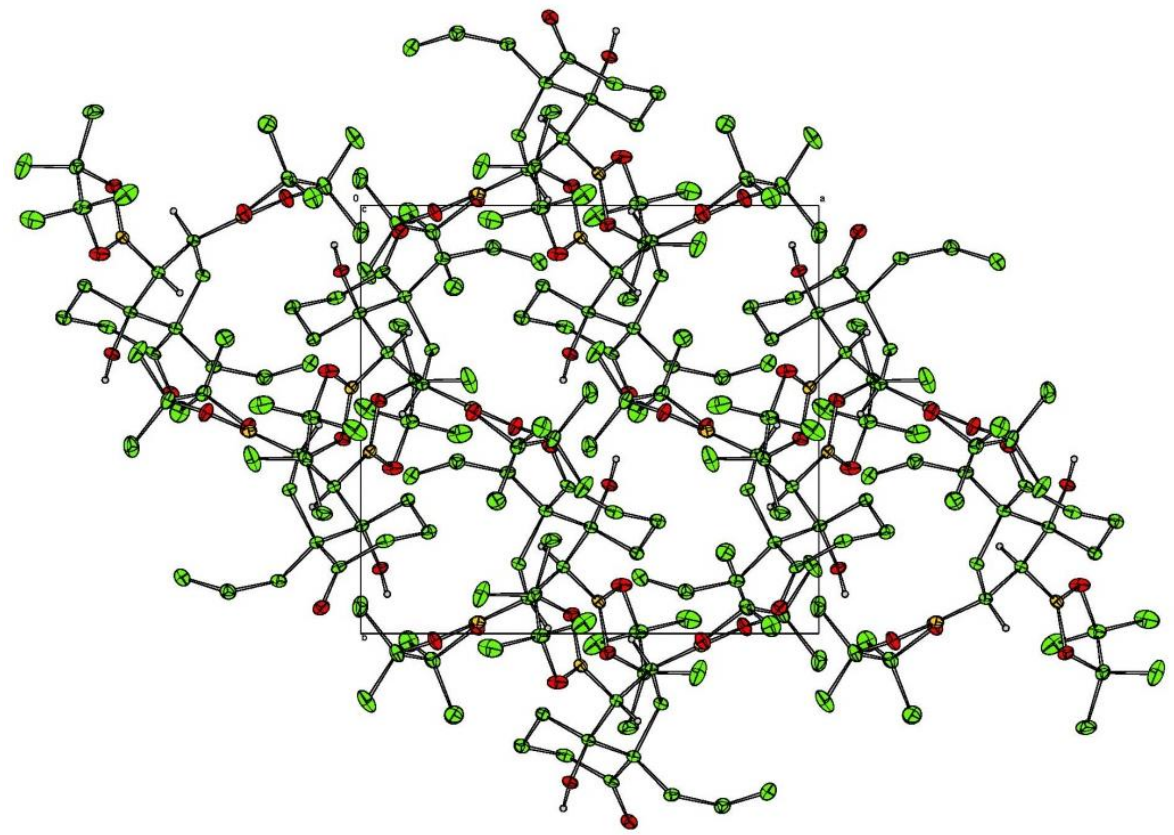

Cell plot, viewed along c- axis 
Table S10. Crystal data and structure refinement for 19003. (CCDC 1916346)

Empirical formula

Formula weight

Crystal color, shape, size

$\mathrm{mm}^{3}$

Temperature

Wavelength

Crystal system, space group

Unit cell dimensions

Volume

Z

Density (calculated)

Absorption coefficient

$\mathrm{F}(000)$

Data collection

Diffractometer

Theta range for data collection

Index ranges

Reflections collected

Independent reflections

Observed Reflections

Completeness to theta $=49.275^{\circ}$

Solution and Refinement

Absorption correction

Max. and min. transmission

Solution

Refinement method

Weighting scheme

Data / restraints / parameters

Goodness-of-fit on $\mathrm{F}^{2}$

Final $\mathrm{R}$ indices [I>2sigma(I)]

$\mathrm{R}$ indices (all data)

Largest diff. peak and hole
C24 H40 B2 O6

446.20

colorless block fragment, 0.200 x $0.200 \times 0.200$

$150 \mathrm{~K}$

$1.54178 \AA$

Monoclinic, $\mathrm{P} 2 \mathrm{1} / \mathrm{n}$

$\mathrm{a}=11.7632(2) \AA$

$\alpha=90^{\circ}$.

$\mathrm{b}=10.96830(10) \AA$

$\beta=95.9823(7)^{\circ}$.

$\mathrm{c}=19.8860(3) \AA$

2551.77(6) $\AA^{3}$

$\gamma=90^{\circ}$.

4

$1.161 \mathrm{Mg} / \mathrm{m}^{3}$

$0.641 \mathrm{~mm}^{-1}$

968

Bruker Apex Kappa Duo, Bruker

4.185 to $66.588^{\circ}$.

$-12<=\mathrm{h}<=13,-12<=\mathrm{k}<=13,-23<=1<=22$

22245

$4456[\mathrm{R}(\mathrm{int})=0.022]$

4166

$99.5 \%$

Semi-empirical from equivalents

0.88 and 0.88

Direct methods

Full-matrix least-squares on $\mathrm{F}^{2}$

$\mathrm{w}=\left[\sigma^{2} \mathrm{Fo}^{2}+\mathrm{AP}^{2}+\mathrm{BP}\right]^{-1}$, with

$\mathrm{P}=\left(\mathrm{Fo}^{2}+2 \mathrm{Fc}^{2}\right) / 3, \mathrm{~A}=0.051, \mathrm{~B}=1.055$

$4436 / 2$ / 410

1.0234

$\mathrm{R} 1=0.0390, \mathrm{wR} 2=0.1012$

$\mathrm{R} 1=0.0410, \mathrm{wR} 2=0.1030$

0.25 and -0.19 e. $\AA^{-3}$ 
Table S11. Atomic coordinates $\left(\AA^{2} \times 1^{4}\right)$ and equivalent isotropic displacement parameters $\left(\AA^{2} \times 10^{3}\right)$ for 19003 . $U(e q)$ is defined as one third of the trace of the orthogonalized $U^{i j}$ tensor.

\begin{tabular}{|c|c|c|c|c|}
\hline & $\mathrm{x}$ & $\mathrm{y}$ & $\mathrm{z}$ & $\mathrm{U}(\mathrm{eq})$ \\
\hline $\mathrm{O} 1$ & $4138(1)$ & $5608(1)$ & 4452(1) & 36 \\
\hline $\mathrm{O} 2$ & $5427(1)$ & $6530(1)$ & $6295(1)$ & 28 \\
\hline $\mathrm{O} 3$ & $5699(1)$ & $8866(1)$ & $7409(1)$ & 45 \\
\hline $\mathrm{O} 4$ & $5396(1)$ & $10450(1)$ & $6679(1)$ & 33 \\
\hline O5 & 2533(1) & $9830(1)$ & $6743(1)$ & 38 \\
\hline O6 & $1623(1)$ & $10166(1)$ & $5690(1)$ & 38 \\
\hline $\mathrm{C} 1$ & $4528(1)$ & $6553(1)$ & $4698(1)$ & 27 \\
\hline $\mathrm{C} 2$ & $5536(1)$ & $7160(1)$ & 4431(1) & 34 \\
\hline $\mathrm{C} 3$ & $6485(1)$ & $7375(1)$ & $5006(1)$ & 34 \\
\hline $\mathrm{C} 4$ & $6027(1)$ & $8122(1)$ & $5564(1)$ & 28 \\
\hline C5 & $5023(1)$ & $7514(1)$ & $5869(1)$ & 24 \\
\hline C6 & $4418(1)$ & $8436(1)$ & 6293(1) & 23 \\
\hline C7 & $3648(1)$ & 9181(1) & $5763(1)$ & 24 \\
\hline $\mathrm{C} 8$ & $3446(1)$ & $8367(1)$ & $5119(1)$ & 26 \\
\hline C9 & 4042(1) & 7131(1) & $5305(1)$ & 24 \\
\hline $\mathrm{C} 10$ & $3209(1)$ & $6235(1)$ & $5606(1)$ & 30 \\
\hline C11 & 2104(1) & 5981(1) & $5179(1)$ & 38 \\
\hline $\mathrm{C} 12$ & $1100(2)$ & $6312(2)$ & $5323(1)$ & 55 \\
\hline $\mathrm{C} 13$ & 6074(1) & $9953(1)$ & 7792(1) & 40 \\
\hline $\mathrm{C} 14$ & $7165(3)$ & $9664(2)$ & $8238(1)$ & 79 \\
\hline C15 & $5127(2)$ & $10245(2)$ & $8225(1)$ & 69 \\
\hline C16 & 6201(1) & $10905(1)$ & 7231(1) & 34 \\
\hline $\mathrm{C} 17$ & $7365(2)$ & 10917(3) & $6975(1)$ & 73 \\
\hline $\mathrm{C} 18$ & $5841(2)$ & $12187(2)$ & 7401(1) & 54 \\
\hline C19 & $1566(1)$ & $10617(1)$ & 6844(1) & 38 \\
\hline $\mathrm{C} 20$ & $2035(2)$ & $11898(2)$ & 6953(1) & 60 \\
\hline $\mathrm{C} 21$ & $1047(2)$ & $10178(2)$ & $7469(1)$ & 55 \\
\hline $\mathrm{C} 22$ & 791(1) & $10455(2)$ & $6168(1)$ & 39 \\
\hline $\mathrm{C} 23$ & $-8(2)$ & $9368(2)$ & 6164(1) & 56 \\
\hline $\mathrm{C} 24$ & $130(2)$ & $11577(2)$ & $5915(1)$ & 63 \\
\hline B1 & $5198(1)$ & $9253(1)$ & $6798(1)$ & 26 \\
\hline B2 & 2574(1) & $9724(1)$ & 6061(1) & 27 \\
\hline
\end{tabular}


Table S12. Bond lengths $[\AA]$ and angles $\left[^{\circ}\right]$ for 19003 .

\begin{tabular}{|c|c|c|c|}
\hline $\mathrm{O} 1-\mathrm{C} 1$ & $1.2151(17)$ & $\mathrm{O} 2-\mathrm{C} 5$ & $1.4226(15)$ \\
\hline $\mathrm{O} 2-\mathrm{H} 1$ & $0.842(14)$ & $\mathrm{O} 3-\mathrm{C} 13$ & $1.4583(17)$ \\
\hline O3-B1 & $1.3616(17)$ & O4-C16 & $1.4607(16)$ \\
\hline O4-B1 & $1.3585(18)$ & O5-C19 & $1.4584(17)$ \\
\hline O5-B2 & $1.3666(18)$ & O6-C22 & $1.4675(17)$ \\
\hline O6-B2 & $1.3632(18)$ & $\mathrm{C} 1-\mathrm{C} 2$ & $1.504(2)$ \\
\hline $\mathrm{C} 1-\mathrm{C} 9$ & $1.5266(17)$ & $\mathrm{C} 2-\mathrm{C} 3$ & $1.531(2)$ \\
\hline C2-H21 & $0.970(18)$ & $\mathrm{C} 2-\mathrm{H} 22$ & $0.992(18)$ \\
\hline C3-C4 & $1.5212(19)$ & $\mathrm{C} 3-\mathrm{H} 31$ & $0.978(18)$ \\
\hline C3-H32 & $0.997(18)$ & $\mathrm{C} 4-\mathrm{C} 5$ & $1.5345(18)$ \\
\hline C4-H41 & $0.976(16)$ & $\mathrm{C} 4-\mathrm{H} 42$ & 0.984(17) \\
\hline C5-C6 & $1.5378(17)$ & C5-C9 & $1.5807(16)$ \\
\hline C6-C7 & $1.5489(16)$ & C6-B1 & $1.5697(19)$ \\
\hline C6-H61 & $0.969(15)$ & $\mathrm{C} 7-\mathrm{C} 8$ & $1.5592(17)$ \\
\hline C7-B2 & $1.5675(19)$ & C7-H71 & $0.959(16)$ \\
\hline C8-C9 & $1.5532(17)$ & C8-H81 & $0.980(16)$ \\
\hline C8-H82 & $0.947(16)$ & C9-C10 & $1.5505(18)$ \\
\hline C10-C11 & $1.502(2)$ & C10-H101 & $0.974(17)$ \\
\hline C10-H102 & $0.987(17)$ & $\mathrm{C} 11-\mathrm{C} 12$ & $1.296(3)$ \\
\hline C11-H111 & $0.964(19)$ & C12-H121 & $0.96(2)$ \\
\hline C12-H122 & $0.96(2)$ & C13-C14 & $1.515(2)$ \\
\hline C13-C15 & $1.512(3)$ & C13-C16 & $1.547(2)$ \\
\hline C14-H141 & $0.99(3)$ & C14-H142 & $0.97(3)$ \\
\hline C14-H143 & $1.04(3)$ & C15-H151 & $0.99(3)$ \\
\hline C15-H152 & $0.95(3)$ & C15-H153 & $1.00(3)$ \\
\hline C16-C17 & $1.510(2)$ & C16-C18 & $1.517(2)$ \\
\hline C17-H171 & $0.96(3)$ & C17-H172 & $1.01(3)$ \\
\hline C17-H173 & $0.99(3)$ & C18-H181 & $0.97(2)$ \\
\hline C18-H182 & $0.97(2)$ & C18-H183 & $1.05(2)$ \\
\hline C19-C20 & $1.517(3)$ & C19-C21 & $1.521(2)$ \\
\hline C19-C22 & $1.554(2)$ & $\mathrm{C} 20-\mathrm{H} 201$ & $0.93(2)$ \\
\hline C20-H202 & $0.97(2)$ & $\mathrm{C} 20-\mathrm{H} 203$ & $0.99(2)$ \\
\hline $\mathrm{C} 21-\mathrm{H} 211$ & $0.99(2)$ & $\mathrm{C} 21-\mathrm{H} 212$ & $0.99(2)$ \\
\hline C21-H213 & $1.04(2)$ & $\mathrm{C} 22-\mathrm{C} 23$ & $1.517(3)$ \\
\hline C22-C24 & $1.513(2)$ & $\mathrm{C} 23-\mathrm{H} 231$ & $1.00(2)$ \\
\hline $\mathrm{C} 23-\mathrm{H} 232$ & $0.96(2)$ & $\mathrm{C} 23-\mathrm{H} 233$ & $1.03(2)$ \\
\hline C24-H241 & $1.01(2)$ & $\mathrm{C} 24-\mathrm{H} 242$ & $0.98(2)$ \\
\hline $\mathrm{C} 24-\mathrm{H} 243$ & $1.00(2)$ & & \\
\hline
\end{tabular}




\begin{tabular}{|c|c|}
\hline C5-O2-H1 & $110.2(12)$ \\
\hline C16-O4-B1 & $107.95(11)$ \\
\hline C22-O6-B2 & 107.01(11) \\
\hline O1-C1-C9 & $121.07(13)$ \\
\hline $\mathrm{C} 1-\mathrm{C} 2-\mathrm{C} 3$ & $110.20(11)$ \\
\hline C3-C2-H21 & $108.2(10)$ \\
\hline C3-C2-H22 & $112.7(10)$ \\
\hline C2-C3-C4 & $109.97(12)$ \\
\hline C4-C3-H31 & $108.5(10)$ \\
\hline C4-C3-H32 & 110.2(10) \\
\hline C3-C4-C5 & $113.57(11)$ \\
\hline C5-C4-H41 & $107.0(9)$ \\
\hline C5-C4-H42 & $108.9(9)$ \\
\hline $\mathrm{C} 4-\mathrm{C} 5-\mathrm{O} 2$ & $110.02(10)$ \\
\hline $\mathrm{O} 2-\mathrm{C} 5-\mathrm{C} 6$ & 108.51(9) \\
\hline $\mathrm{O} 2-\mathrm{C} 5-\mathrm{C} 9$ & $113.22(10)$ \\
\hline C5-C6-C7 & $104.22(9)$ \\
\hline C7-C6-B1 & $113.33(10)$ \\
\hline C7-C6-H61 & $110.1(9)$ \\
\hline C6-C7-C8 & $106.56(10)$ \\
\hline C8-C7-B2 & $117.94(11)$ \\
\hline C8-C7-H71 & $106.5(9)$ \\
\hline C7-C8-C9 & $106.12(10)$ \\
\hline C9-C8-H81 & $110.6(9)$ \\
\hline C9-C8-H82 & $110.6(10)$ \\
\hline C8-C9-C1 & $111.74(10)$ \\
\hline C1-C9-C5 & $111.44(10)$ \\
\hline C1-C9-C10 & $110.21(11)$ \\
\hline C9-C10-C11 & $116.34(11)$ \\
\hline C11-C10-H101 & 109.3(9) \\
\hline C11-C10-H102 & $107.4(9)$ \\
\hline C10-C11-C12 & $125.35(17)$ \\
\hline C12-C11-H111 & $119.8(11)$ \\
\hline C11-C12-H122 & $123.3(13)$ \\
\hline O3-C13-C14 & $109.06(14)$ \\
\hline C14-C13-C15 & 109.92(19) \\
\hline C14-C13-C16 & $115.05(17)$ \\
\hline C13-C14-H141 & $108.4(15)$ \\
\hline H141-C14-H142 & $111(2)$ \\
\hline H141-C14-H143 & $110(2)$ \\
\hline C13-C15-H151 & $108.6(14)$ \\
\hline H151-C15-H152 & $110(2)$ \\
\hline H151-C15-H153 & $111(2)$ \\
\hline
\end{tabular}

\begin{tabular}{|c|c|}
\hline C13-O3-B1 & $106.87(11)$ \\
\hline C19-O5-B2 & $107.22(11)$ \\
\hline $\mathrm{O} 1-\mathrm{C} 1-\mathrm{C} 2$ & $120.90(12)$ \\
\hline C2-C1-C9 & $117.99(11)$ \\
\hline C1-C2-H21 & $109.5(10)$ \\
\hline C1-C2-H22 & $109.3(10)$ \\
\hline H21-C2-H22 & $106.9(14)$ \\
\hline C2-C3-H31 & $111.7(10)$ \\
\hline C2-C3-H32 & 109.7(10) \\
\hline H31-C3-H32 & $106.7(14)$ \\
\hline C3-C4-H41 & 109.9(9) \\
\hline C3-C4-H42 & 109.1(9) \\
\hline H41-C4-H42 & $108.3(13)$ \\
\hline C4-C5-C6 & $110.51(10)$ \\
\hline C4-C5-C9 & $111.74(10)$ \\
\hline C6-C5-C9 & $102.58(9)$ \\
\hline C5-C6-B1 & $116.95(10)$ \\
\hline C5-C6-H61 & $106.2(9)$ \\
\hline B1-C6-H61 & $105.8(9)$ \\
\hline C6-C7-B2 & $112.35(10)$ \\
\hline C6-C7-H71 & 107.2(9) \\
\hline B2-C7-H71 & 105.7(9) \\
\hline C7-C8-H81 & $110.5(9)$ \\
\hline C7-C8-H82 & $112.5(9)$ \\
\hline H81-C8-H82 & $106.5(13)$ \\
\hline C8-C9-C5 & $102.42(9)$ \\
\hline C8-C9-C10 & $110.97(11)$ \\
\hline C5-C9-C10 & $109.83(10)$ \\
\hline C9-C10-H101 & 107.1(10) \\
\hline C9-C10-H102 & 106.9(9) \\
\hline H101-C10-H102 & $109.6(14)$ \\
\hline C10-C11-H111 & $114.8(11)$ \\
\hline C11-C12-H121 & $118.0(13)$ \\
\hline $\mathrm{H} 121-\mathrm{C} 12-\mathrm{H} 122$ & 118.6(19) \\
\hline O3-C13-C15 & $105.67(14)$ \\
\hline O3-C13-C16 & $102.80(11)$ \\
\hline C15-C13-C16 & $113.60(16)$ \\
\hline C13-C14-H142 & $113.7(17)$ \\
\hline C13-C14-H143 & $106.0(15)$ \\
\hline H142-C14-H143 & $108(2)$ \\
\hline C13-C15-H152 & $107.8(16)$ \\
\hline C13-C15-H153 & $111.4(15)$ \\
\hline H152-C15-H153 & $108(2)$ \\
\hline
\end{tabular}




\begin{tabular}{|c|c|c|c|}
\hline C13-C16-O4 & $102.00(11)$ & C13-C16-C17 & $114.12(17)$ \\
\hline O4-C16-C17 & $106.80(13)$ & C13-C16-C18 & $114.47(14)$ \\
\hline O4-C16-C18 & $108.09(12)$ & C17-C16-C18 & $110.55(17)$ \\
\hline C16-C17-H171 & $108.1(17)$ & C16-C17-H172 & 111.1(15) \\
\hline H171-C17-H172 & $110(2)$ & C16-C17-H173 & $110.8(15)$ \\
\hline H171-C17-H173 & $109(2)$ & H172-C17-H173 & $107(2)$ \\
\hline C16-C18-H181 & $109.2(13)$ & C16-C18-H182 & $109.5(13)$ \\
\hline H181-C18-H182 & 104.7(17) & C16-C18-H183 & $110.2(12)$ \\
\hline H181-C18-H183 & $111.4(17)$ & H182-C18-H183 & $111.6(17)$ \\
\hline O5-C19-C20 & $106.89(13)$ & O5-C19-C21 & $108.09(14)$ \\
\hline C20-C19-C21 & $110.36(15)$ & $\mathrm{O} 5-\mathrm{C} 19-\mathrm{C} 22$ & $102.05(11)$ \\
\hline C20-C19-C22 & $113.68(16)$ & C21-C19-C22 & $114.97(14)$ \\
\hline C19-C20-H201 & $111.6(14)$ & C19-C20-H202 & 107.6(14) \\
\hline H201-C20-H202 & 109.5(19) & C19-C20-H203 & $112.3(14)$ \\
\hline H201-C20-H203 & $105.8(19)$ & H202-C20-H203 & $110.0(19)$ \\
\hline C19-C21-H211 & 108.6(13) & C19-C21-H212 & $107.8(13)$ \\
\hline $\mathrm{H} 211-\mathrm{C} 21-\mathrm{H} 212$ & $107.4(18)$ & C19-C21-H213 & $112.1(12)$ \\
\hline $\mathrm{H} 211-\mathrm{C} 21-\mathrm{H} 213$ & $108.4(17)$ & $\mathrm{H} 212-\mathrm{C} 21-\mathrm{H} 213$ & $112.4(18)$ \\
\hline C19-C22-O6 & $102.32(11)$ & C19-C22-C23 & $113.66(15)$ \\
\hline $\mathrm{O} 6-\mathrm{C} 22-\mathrm{C} 23$ & $106.34(13)$ & C19-C22-C24 & $115.38(16)$ \\
\hline O6-C22-C24 & $108.42(13)$ & C23-C22-C24 & $109.93(16)$ \\
\hline C22-C23-H231 & $108.8(13)$ & $\mathrm{C} 22-\mathrm{C} 23-\mathrm{H} 232$ & $109.5(13)$ \\
\hline $\mathrm{H} 231-\mathrm{C} 23-\mathrm{H} 232$ & $105.1(17)$ & $\mathrm{C} 22-\mathrm{C} 23-\mathrm{H} 233$ & $110.6(12)$ \\
\hline $\mathrm{H} 231-\mathrm{C} 23-\mathrm{H} 233$ & 111.9(18) & $\mathrm{H} 232-\mathrm{C} 23-\mathrm{H} 233$ & $110.7(18)$ \\
\hline C22-C24-H241 & $107.9(14)$ & C22-C24-H242 & $107.8(14)$ \\
\hline $\mathrm{H} 241-\mathrm{C} 24-\mathrm{H} 242$ & $109.8(19)$ & $\mathrm{C} 22-\mathrm{C} 24-\mathrm{H} 243$ & 109.3(13) \\
\hline $\mathrm{H} 241-\mathrm{C} 24-\mathrm{H} 243$ & $118.0(20)$ & $\mathrm{H} 242-\mathrm{C} 24-\mathrm{H} 243$ & $103.5(19)$ \\
\hline C6-B1-O3 & $124.26(12)$ & C6-B1-O4 & $122.62(12)$ \\
\hline O3-B1-O4 & $113.04(12)$ & C7-B2-O5 & $121.40(12)$ \\
\hline C7-B2-O6 & $125.37(12)$ & O5-B2-O6 & $113.20(12)$ \\
\hline
\end{tabular}

Symmetry transformations used to generate equivalent atoms: 
Table S13. Anisotropic displacement parameters $\left(\AA^{2} \times 10^{3}\right)$ for 19003. The anisotropic displacement factor exponent takes the form: $-2 \pi^{2}\left[h^{2} a^{* 2} U^{11}+\ldots+2 h k^{*} b^{*} U^{12}\right]$

\begin{tabular}{|c|c|c|c|c|c|c|}
\hline & $\mathrm{U}^{11}$ & $\mathrm{U}^{22}$ & $\mathrm{U}^{33}$ & $\mathrm{U}^{23}$ & $\mathrm{U}^{13}$ & $\mathrm{U}^{12}$ \\
\hline $\mathrm{O} 1$ & $41(1)$ & $34(1)$ & $31(1)$ & $-13(1)$ & $-7(1)$ & $7(1)$ \\
\hline $\mathrm{O} 2$ & $39(1)$ & $24(1)$ & $20(1)$ & $0(1)$ & $-1(1)$ & $7(1)$ \\
\hline $\mathrm{O} 3$ & $70(1)$ & $28(1)$ & $30(1)$ & $-4(1)$ & $-20(1)$ & $1(1)$ \\
\hline $\mathrm{O} 4$ & $41(1)$ & $29(1)$ & $27(1)$ & $-1(1)$ & $-6(1)$ & $-6(1)$ \\
\hline $\mathrm{O} 5$ & $38(1)$ & $49(1)$ & $25(1)$ & $-7(1)$ & $4(1)$ & $12(1)$ \\
\hline O6 & $33(1)$ & $52(1)$ & $28(1)$ & $2(1)$ & $6(1)$ & $15(1)$ \\
\hline $\mathrm{C} 1$ & $38(1)$ & $24(1)$ & $18(1)$ & $1(1)$ & $-5(1)$ & $10(1)$ \\
\hline $\mathrm{C} 2$ & $54(1)$ & $28(1)$ & $23(1)$ & $0(1)$ & 11(1) & $9(1)$ \\
\hline $\mathrm{C} 3$ & $38(1)$ & $32(1)$ & $32(1)$ & $1(1)$ & $12(1)$ & $4(1)$ \\
\hline $\mathrm{C} 4$ & $31(1)$ & $28(1)$ & $27(1)$ & $0(1)$ & $4(1)$ & $2(1)$ \\
\hline C5 & $30(1)$ & $22(1)$ & $18(1)$ & $0(1)$ & $0(1)$ & $4(1)$ \\
\hline C6 & $28(1)$ & $23(1)$ & 19(1) & $0(1)$ & $3(1)$ & $2(1)$ \\
\hline $\mathrm{C} 7$ & $29(1)$ & $21(1)$ & $21(1)$ & $0(1)$ & $1(1)$ & $1(1)$ \\
\hline $\mathrm{C} 8$ & $32(1)$ & $24(1)$ & $20(1)$ & $-1(1)$ & $0(1)$ & $4(1)$ \\
\hline C9 & $32(1)$ & $22(1)$ & $18(1)$ & $0(1)$ & $0(1)$ & $3(1)$ \\
\hline $\mathrm{C} 10$ & $39(1)$ & $25(1)$ & $25(1)$ & $0(1)$ & $-1(1)$ & $-2(1)$ \\
\hline C11 & $40(1)$ & $36(1)$ & $37(1)$ & $0(1)$ & $-1(1)$ & $-3(1)$ \\
\hline $\mathrm{C} 12$ & $40(1)$ & $46(1)$ & $80(1)$ & $0(1)$ & $10(1)$ & $-10(1)$ \\
\hline $\mathrm{C} 13$ & $55(1)$ & $32(1)$ & $30(1)$ & $-9(1)$ & $-12(1)$ & $-1(1)$ \\
\hline $\mathrm{C} 14$ & $101(2)$ & $53(1)$ & $69(1)$ & $-14(1)$ & $-55(1)$ & 11(1) \\
\hline $\mathrm{C} 15$ & $96(2)$ & $73(1)$ & $41(1)$ & $-22(1)$ & $24(1)$ & $-30(1)$ \\
\hline $\mathrm{C} 16$ & $32(1)$ & $36(1)$ & $32(1)$ & $-9(1)$ & $-3(1)$ & $-5(1)$ \\
\hline $\mathrm{C} 17$ & $45(1)$ & $108(2)$ & $69(1)$ & $-35(1)$ & $16(1)$ & $-29(1)$ \\
\hline $\mathrm{C} 18$ & $68(1)$ & $32(1)$ & $59(1)$ & $-9(1)$ & $-11(1)$ & $-5(1)$ \\
\hline C19 & $38(1)$ & $42(1)$ & $36(1)$ & $-9(1)$ & 11(1) & $8(1)$ \\
\hline $\mathrm{C} 20$ & $57(1)$ & $52(1)$ & $75(1)$ & $-28(1)$ & $23(1)$ & $-2(1)$ \\
\hline $\mathrm{C} 21$ & $62(1)$ & $70(1)$ & $37(1)$ & $-8(1)$ & $20(1)$ & $6(1)$ \\
\hline $\mathrm{C} 22$ & $33(1)$ & $49(1)$ & $37(1)$ & $-2(1)$ & $10(1)$ & $12(1)$ \\
\hline $\mathrm{C} 23$ & $37(1)$ & $72(1)$ & $60(1)$ & $-20(1)$ & $14(1)$ & $-5(1)$ \\
\hline $\mathrm{C} 24$ & $53(1)$ & $77(2)$ & $62(1)$ & $10(1)$ & $15(1)$ & $34(1)$ \\
\hline B1 & $28(1)$ & $27(1)$ & $22(1)$ & $-4(1)$ & $3(1)$ & $5(1)$ \\
\hline B2 & $32(1)$ & $24(1)$ & $25(1)$ & $-1(1)$ & $2(1)$ & $1(1)$ \\
\hline
\end{tabular}


Table S14. Hydrogen coordinates ( $\left.x 1^{4}\right)$ and isotropic displacement parameters $\left(\AA^{2} \times 10\right.$ 3) for 19003 .

\begin{tabular}{|c|c|c|c|c|}
\hline & $\mathrm{x}$ & $\mathrm{y}$ & $\mathrm{z}$ & $\mathrm{U}(\mathrm{eq})$ \\
\hline $\mathrm{H} 21$ & $5304(14)$ & 7944(17) & 4237(9) & 41 \\
\hline $\mathrm{H} 22$ & $5793(14)$ & $6659(16)$ & 4060(9) & 41 \\
\hline H31 & $7134(15)$ & $7809(16)$ & 4849(8) & 40 \\
\hline H32 & $6782(14)$ & $6577(17)$ & $5189(8)$ & 40 \\
\hline $\mathrm{H} 41$ & $6629(14)$ & $8247(15)$ & 5933(8) & 34 \\
\hline $\mathrm{H} 42$ & $5779(13)$ & $8924(16)$ & $5382(8)$ & 34 \\
\hline H61 & $3950(12)$ & $7960(14)$ & $6569(8)$ & 28 \\
\hline H71 & $4085(13)$ & $9870(15)$ & $5641(8)$ & 28 \\
\hline H81 & $3777(13)$ & $8749(14)$ & $4738(8)$ & 31 \\
\hline H82 & $2659(14)$ & $8248(14)$ & 4977(8) & 31 \\
\hline H101 & $3046(13)$ & $6568(15)$ & 6039(9) & 36 \\
\hline H102 & $3617(14)$ & $5451(16)$ & $5678(8)$ & 36 \\
\hline H111 & $2177(15)$ & $5499(17)$ & $4781(10)$ & 46 \\
\hline H121 & 1051(18) & $6770(20)$ & $5730(11)$ & 66 \\
\hline H122 & 407(19) & $6120(20)$ & $5045(11)$ & 66 \\
\hline H141 & $7410(20)$ & $10410(30)$ & $8495(14)$ & 94 \\
\hline H142 & 7090(20) & $8980(30)$ & $8542(14)$ & 94 \\
\hline H143 & $7760(20)$ & $9430(30)$ & 7913(14) & 94 \\
\hline H151 & $5370(20)$ & $10950(20)$ & $8522(13)$ & 83 \\
\hline H152 & $5000(20)$ & $9540(20)$ & $8489(13)$ & 83 \\
\hline H153 & $4390(20)$ & $10440(20)$ & 7941(13) & 83 \\
\hline H171 & $7320(20)$ & $11410(20)$ & $6574(15)$ & 88 \\
\hline H172 & $7960(20)$ & $11250(20)$ & $7327(14)$ & 88 \\
\hline H173 & $7600(20)$ & $10080(30)$ & $6866(14)$ & 88 \\
\hline H181 & $5963(18)$ & $12730(20)$ & $7028(11)$ & 65 \\
\hline H182 & $6345(18)$ & $12490(20)$ & 7781(11) & 65 \\
\hline H183 & 4980(19) & $12190(20)$ & $7504(10)$ & 65 \\
\hline H201 & $1470(20)$ & $12450(20)$ & $7036(11)$ & 72 \\
\hline H202 & $2610(20)$ & $11870(20)$ & $7339(12)$ & 72 \\
\hline H203 & $2370(20)$ & $12210(20)$ & $6551(12)$ & 72 \\
\hline $\mathrm{H} 211$ & 394(19) & $10710(20)$ & $7544(11)$ & 66 \\
\hline $\mathrm{H} 212$ & 1631(19) & $10280(20)$ & $7863(12)$ & 66 \\
\hline $\mathrm{H} 213$ & 751(18) & $9290(20)$ & $7418(11)$ & 66 \\
\hline $\mathrm{H} 231$ & $-406(18)$ & $9270(20)$ & $5698(12)$ & 67 \\
\hline $\mathrm{H} 232$ & $-605(19)$ & $9540(20)$ & $6446(11)$ & 67 \\
\hline H233 & $436(19)$ & $8600(20)$ & $6327(11)$ & 67 \\
\hline
\end{tabular}




\begin{tabular}{lrrll}
$\mathrm{H} 241$ & $-390(20)$ & $11340(20)$ & $5499(13)$ & 76 \\
$\mathrm{H} 242$ & $-330(20)$ & $11840(20)$ & $6270(12)$ & 76 \\
$\mathrm{H} 243$ & $670(20)$ & $12270(20)$ & $5879(12)$ & 76 \\
$\mathrm{H} 1$ & $5577(15)$ & $5924(14)$ & $6060(8)$ & $43(2)$ \\
\hline
\end{tabular}

Table S15. Torsion angles $\left[{ }^{\circ}\right]$ for 19003 .

\begin{tabular}{|c|c|c|c|}
\hline B1-O3-C13-C14 & $-146.41(16)$ & B1-O3-C13-C15 & $95.47(14)$ \\
\hline B1-O3-C13-C16 & $-23.88(15)$ & C13-O3-B1-O4 & $12.32(16)$ \\
\hline C13-O3-B1-C6 & $-164.73(13)$ & B1-O4-C16-C13 & $-20.14(14)$ \\
\hline B1-O4-C16-C17 & 99.89(17) & B1-O4-C16-C18 & $-141.13(13)$ \\
\hline C16-O4-B1-O3 & $5.94(15)$ & C16-O4-B1-C6 & $-176.97(12)$ \\
\hline B2-O5-C19-C20 & $-95.31(16)$ & B2-O5-C19-C21 & $145.88(13)$ \\
\hline B2-O5-C19-C22 & $24.29(14)$ & C19-O5-B2-O6 & $-11.41(16)$ \\
\hline C19-O5-B2-C7 & $166.68(12)$ & B2-O6-C22-C19 & $22.35(15)$ \\
\hline B2-O6-C22-C23 & $-97.12(14)$ & B2-O6-C22-C24 & $144.72(14)$ \\
\hline C22-O6-B2-O5 & $-7.99(16)$ & C22-O6-B2-C7 & $174.02(13)$ \\
\hline O1-C1-C2-C3 & $-125.68(14)$ & $\mathrm{C} 9-\mathrm{C} 1-\mathrm{C} 2-\mathrm{C} 3$ & $51.75(16)$ \\
\hline O1-C1-C9-C5 & $132.70(12)$ & $\mathrm{O} 1-\mathrm{C} 1-\mathrm{C} 9-\mathrm{C} 8$ & $-113.39(14)$ \\
\hline O1-C1-C9-C10 & 10.49(17) & $\mathrm{C} 2-\mathrm{C} 1-\mathrm{C} 9-\mathrm{C} 5$ & $-44.73(15)$ \\
\hline C2-C1-C9-C8 & $69.18(15)$ & $\mathrm{C} 2-\mathrm{C} 1-\mathrm{C} 9-\mathrm{C} 10$ & $-166.94(11)$ \\
\hline C1-C2-C3-C4 & $-56.35(15)$ & $\mathrm{C} 2-\mathrm{C} 3-\mathrm{C} 4-\mathrm{C} 5$ & $59.34(15)$ \\
\hline $\mathrm{C} 3-\mathrm{C} 4-\mathrm{C} 5-\mathrm{O} 2$ & $74.33(13)$ & C3-C4-C5-C6 & $-165.86(11)$ \\
\hline C3-C4-C5-C9 & $-52.32(14)$ & $\mathrm{O} 2-\mathrm{C} 5-\mathrm{C} 6-\mathrm{C} 7$ & $-159.73(10)$ \\
\hline O2-C5-C6-B1 & $74.31(13)$ & C4-C5-C6-C7 & $79.56(12)$ \\
\hline C4-C5-C6-B1 & $-46.40(14)$ & C9-C5-C6-C7 & $-39.69(11)$ \\
\hline C9-C5-C6-B1 & $-165.65(10)$ & $\mathrm{O} 2-\mathrm{C} 5-\mathrm{C} 9-\mathrm{C} 1$ & $-82.14(12)$ \\
\hline $\mathrm{O} 2-\mathrm{C} 5-\mathrm{C} 9-\mathrm{C} 8$ & $158.27(10)$ & $\mathrm{O} 2-\mathrm{C} 5-\mathrm{C} 9-\mathrm{C} 10$ & 40.30(14) \\
\hline C4-C5-C9-C1 & $42.75(14)$ & $\mathrm{C} 4-\mathrm{C} 5-\mathrm{C} 9-\mathrm{C} 8$ & $-76.84(12)$ \\
\hline C4-C5-C9-C10 & $165.19(11)$ & C6-C5-C9-C1 & $161.14(10)$ \\
\hline C6-C5-C9-C8 & $41.55(11)$ & C6-C5-C9-C10 & $-76.43(12)$ \\
\hline C5-C6-C7-C8 & $22.72(13)$ & C5-C6-C7-B2 & $153.32(10)$ \\
\hline B1-C6-C7-C8 & $150.93(11)$ & B1-C6-C7-B2 & $-78.48(13)$ \\
\hline C5-C6-B1-O3 & $-77.97(16)$ & C5-C6-B1-O4 & $105.26(14)$ \\
\hline C7-C6-B1-O3 & $160.74(12)$ & C7-C6-B1-O4 & $-16.03(17)$ \\
\hline C6-C7-C8-C9 & $3.52(13)$ & B2-C7-C8-C9 & $-123.83(12)$ \\
\hline C6-C7-B2-O5 & 18.39(17) & C6-C7-B2-O6 & $-163.77(12)$ \\
\hline C8-C7-B2-O5 & $142.92(12)$ & C8-C7-B2-O6 & $-39.24(18)$ \\
\hline C7-C8-C9-C1 & $-146.86(11)$ & C7-C8-C9-C5 & $-27.47(12)$ \\
\hline C7-C8-C9-C10 & $89.69(12)$ & C1-C9-C10-C11 & $-68.85(15)$ \\
\hline C5-C9-C10-C11 & $168.00(11)$ & C8-C9-C10-C11 & $55.47(15)$ \\
\hline $\mathrm{C} 9-\mathrm{C} 10-\mathrm{C} 11-\mathrm{C} 12$ & $-112.32(19)$ & $\mathrm{O} 3-\mathrm{C} 13-\mathrm{C} 16-\mathrm{O} 4$ & $26.30(14)$ \\
\hline
\end{tabular}




$\begin{array}{lrlc}\text { O3-C13-C16-C17 } & -88.46(18) & \text { O3-C13-C16-C18 } & 142.76(14) \\ \text { C14-C13-C16-O4 } & 144.70(14) & \text { C14-C13-C16-C17 } & 29.9(2) \\ \text { C14-C13-C16-C18 } & -98.84(18) & \text { C15-C13-C16-O4 } & -87.38(15) \\ \text { C15-C13-C16-C17 } & 157.86(18) & \text { C15-C13-C16-C18 } & 29.1(2) \\ \text { O5-C19-C22-O6 } & -27.94(14) & \text { O5-C19-C22-C23 } & 86.26(15) \\ \text { O5-C19-C22-C24 } & -145.45(14) & \text { C20-C19-C22-O6 } & 86.77(16) \\ \text { C20-C19-C22-C23 } & -159.03(16) & \text { C20-C19-C22-C24 } & -30.7(2) \\ \text { C21-C19-C22-O6 } & -144.66(14) & \text { C21-C19-C22-C23 } & -30.5(2) \\ \text { C21-C19-C22-C24 } & 97.83(19) & & \end{array}$

Symmetry transformations used to generate equivalent atoms: 
Table S16. Crystal data and structure refinement for (-)-(5b). (CCDC 1922369)

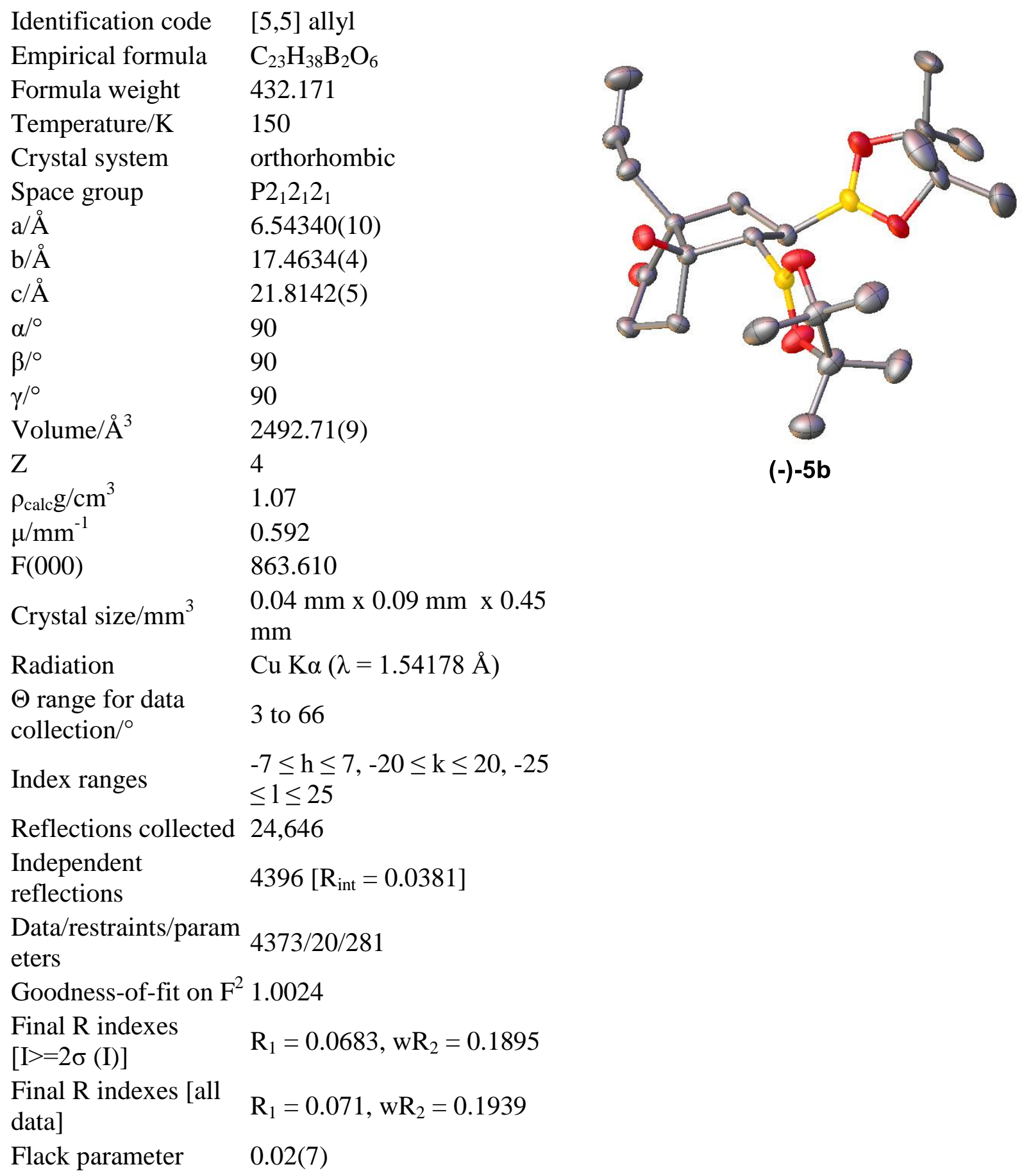


Table S17. Fractional Atomic Coordinates $\left(\AA^{2} \times 10^{4}\right)$ and Equivalent Isotropic Displacement Parameters $\left(\AA^{2} \times 10^{3}\right)$ for $[5,5]$ allyl. $U_{\text {eqis }}$ defined as $1 / 3$ of the trace of the orthogonalised $\mathrm{U}^{\mathrm{IJ}}$ tensor.

\begin{tabular}{|c|c|c|c|c|c|}
\hline Label & $x$ & $y$ & $z$ & $U_{\text {iso/equiv }}$ & Occupancy \\
\hline $\mathrm{O} 1$ & $0.3504(3)$ & $0.36603(12)$ & $0.29201(9)$ & 0.0280 & 1.0000 \\
\hline $\mathrm{O} 2$ & $-0.2937(3)$ & $0.33716(12)$ & $0.36456(10)$ & 0.0296 & 1.0000 \\
\hline $\mathrm{O} 3$ & 0.3202 & 0.6014 & 0.4715 & 0.0419 & 0.7329 \\
\hline $\mathrm{O} 4$ & 0.2976 & 0.4943 & 0.5288 & 0.0481 & 0.7329 \\
\hline $\mathrm{O} 5$ & $0.2734(4)$ & $0.59371(13)$ & $0.30771(13)$ & 0.0409 & 1.0000 \\
\hline $\mathrm{O} 6$ & $0.6001(3)$ & $0.55709(13)$ & $0.32762(11)$ & 0.0369 & 1.0000 \\
\hline $\mathrm{C} 1$ & $0.2084(4)$ & $0.40927(15)$ & $0.32765(12)$ & 0.0213 & 1.0000 \\
\hline $\mathrm{C} 2$ & $0.0553(4)$ & $0.44455(16)$ & $0.28240(12)$ & 0.0231 & 1.0000 \\
\hline $\mathrm{C} 3$ & $-0.1116(4)$ & $0.38407(17)$ & $0.27511(14)$ & 0.0269 & 1.0000 \\
\hline $\mathrm{C} 4$ & $-0.1351(4)$ & $0.35653(16)$ & $0.34061(13)$ & 0.0239 & 1.0000 \\
\hline $\mathrm{C} 5$ & $0.0729(4)$ & $0.35945(15)$ & $0.37236(12)$ & 0.0209 & 1.0000 \\
\hline C6 & $0.0650(5)$ & $0.40427(17)$ & $0.43369(13)$ & 0.0267 & 1.0000 \\
\hline $\mathrm{C} 7$ & $0.1523(4)$ & $0.48473(17)$ & $0.41961(12)$ & 0.0242 & 1.0000 \\
\hline $\mathrm{C} 8$ & $0.3141(4)$ & $0.46854(16)$ & $0.36960(12)$ & 0.0215 & 1.0000 \\
\hline C9 & $0.1547(5)$ & $0.27658(17)$ & $0.37984(15)$ & 0.0290 & 1.0000 \\
\hline $\mathrm{C} 10$ & $0.0356(5)$ & $0.22679(18)$ & $0.42291(16)$ & 0.0360 & 1.0000 \\
\hline C11 & $0.1119(7)$ & $0.1918(2)$ & $0.4702(2)$ & 0.0534 & 1.0000 \\
\hline $\mathrm{C} 12$ & 0.4662 & 0.6110 & 0.5229 & 0.0433 & 0.7329 \\
\hline $\mathrm{C} 13$ & 0.3802 & 0.5534 & 0.5696 & 0.0457 & 0.7329 \\
\hline $\mathrm{C} 14$ & 0.4600 & 0.6941 & 0.5398 & 0.0669 & 0.7329 \\
\hline C15 & 0.6811 & 0.5915 & 0.4967 & 0.0671 & 0.7329 \\
\hline C16 & 0.2149 & 0.5891 & 0.6100 & 0.0603 & 0.7329 \\
\hline C17 & 0.5476 & 0.5143 & 0.6085 & 0.0653 & 0.7329 \\
\hline C18 & $0.3987(5)$ & $0.65666(18)$ & $0.28591(17)$ & 0.0344 & 1.0000 \\
\hline C19 & $0.6190(5)$ & $0.62211(18)$ & $0.28607(16)$ & 0.0329 & 1.0000 \\
\hline $\mathrm{C} 20$ & $0.3687(6)$ & $0.7224(2)$ & $0.3302(2)$ & 0.0504 & 1.0000 \\
\hline $\mathrm{C} 21$ & $0.3226(6)$ & $0.6799(2)$ & $0.22268(19)$ & 0.0482 & 1.0000 \\
\hline $\mathrm{C} 22$ & $0.7817(6)$ & $0.6758(2)$ & $0.3085(2)$ & 0.0534 & 1.0000 \\
\hline $\mathrm{C} 23$ & $0.6776(7)$ & $0.5874(2)$ & $0.22344(18)$ & 0.0526 & 1.0000 \\
\hline B1 & $0.2543(6)$ & $0.5267(2)$ & $0.47613(15)$ & 0.0276 & 1.0000 \\
\hline B2 & $0.3999(5)$ & $0.54158(17)$ & $0.33486(14)$ & 0.0230 & 1.0000 \\
\hline $\mathrm{H} 21$ & $-0.0013(4)$ & $0.49211(16)$ & $0.30026(12)$ & 0.0282 & 1.0000 \\
\hline $\mathrm{H} 22$ & $0.1219(4)$ & $0.45814(16)$ & $0.24485(12)$ & 0.0283 & 1.0000 \\
\hline H31 & $-0.2356(4)$ & $0.40560(17)$ & $0.25776(14)$ & 0.0319 & 1.0000 \\
\hline H32 & $-0.0670(4)$ & $0.34251(17)$ & $0.24892(14)$ & 0.0318 & 1.0000 \\
\hline H61 & $0.1497(5)$ & $0.37733(17)$ & $0.46343(13)$ & 0.0315 & 1.0000 \\
\hline
\end{tabular}




\begin{tabular}{|llllll|}
\hline H62 & $-0.0739(5)$ & $0.40780(17)$ & $0.44924(13)$ & 0.0325 & 1.0000 \\
\hline H71 & $0.0459(4)$ & $0.51505(17)$ & $0.40134(12)$ & 0.0288 & 1.0000 \\
\hline H11 & $0.4278(4)$ & $0.44400(16)$ & $0.38871(12)$ & 0.0255 & 1.0000 \\
\hline H11 & $0.2955(5)$ & $0.28052(17)$ & $0.39562(15)$ & 0.0344 & 1.0000 \\
\hline H92 & $0.1532(5)$ & $0.25119(17)$ & $0.33901(15)$ & 0.0344 & 1.0000 \\
\hline H101 & $-0.1031(5)$ & $0.21995(18)$ & $0.41465(16)$ & 0.0431 & 1.0000 \\
\hline H111 & $0.0272(7)$ & $0.1616(2)$ & $0.4948(2)$ & 0.0645 & 1.0000 \\
\hline H112 & $0.2532(7)$ & $0.1976(2)$ & $0.4774(2)$ & 0.0643 & 1.0000 \\
\hline H141 & $0.5435(13)$ & $0.7018(3)$ & $0.5752(3)$ & 0.1000 & 0.7329 \\
\hline H142 & $0.3226(13)$ & $0.7078(3)$ & $0.5482(3)$ & 0.1002 & 0.7329 \\
\hline H143 & $0.5088(13)$ & $0.7233(3)$ & $0.5064(3)$ & 0.1001 & 0.7329 \\
\hline H151 & $0.7792(9)$ & $0.6018(5)$ & $0.5276(3)$ & 0.1011 & 0.7329 \\
\hline H152 & $0.7086(9)$ & $0.6243(5)$ & $0.4625(3)$ & 0.1008 & 0.7329 \\
\hline H153 & $0.6902(9)$ & $0.5378(5)$ & $0.4852(3)$ & 0.1003 & 0.7329 \\
\hline H161 & $0.1352(9)$ & $0.5487(5)$ & $0.6272(3)$ & 0.0909 & 0.7329 \\
\hline H162 & $0.2712(9)$ & $0.6193(5)$ & $0.6412(3)$ & 0.0902 & 0.7329 \\
\hline H163 & $0.1319(9)$ & $0.6216(5)$ & $0.5864(3)$ & 0.0907 & 0.7329 \\
\hline H171 & $0.4837(12)$ & $0.4744(4)$ & $0.6305(3)$ & 0.0981 & 0.7329 \\
\hline H172 & $0.6055(12)$ & $0.5495(4)$ & $0.6367(3)$ & 0.0979 & 0.7329 \\
\hline H173 & $0.6546(12)$ & $0.4944(4)$ & $0.5835(3)$ & 0.0977 & 0.7329 \\
\hline H201 & $0.4333(6)$ & $0.7681(2)$ & $0.3153(2)$ & 0.0758 & 1.0000 \\
\hline H202 & $0.4241(6)$ & $0.7087(2)$ & $0.3692(2)$ & 0.0755 & 1.0000 \\
\hline H203 & $0.2261(6)$ & $0.7318(2)$ & $0.3353(2)$ & 0.0756 & 1.0000 \\
\hline H211 & $0.4169(6)$ & $0.7177(2)$ & $0.20575(19)$ & 0.0718 & 1.0000 \\
\hline H212 & $0.1826(6)$ & $0.6994(2)$ & $0.22499(19)$ & 0.0722 & 1.0000 \\
\hline H213 & $0.3249(6)$ & $0.6340(2)$ & $0.19932(19)$ & 0.0717 & 1.0000 \\
\hline H221 & $0.9176(6)$ & $0.6525(2)$ & $0.3034(2)$ & 0.0797 & 1.0000 \\
\hline H222 & $0.7589(6)$ & $0.6810(2)$ & $0.3535(2)$ & 0.0787 & 1.0000 \\
\hline H223 & $0.7750(6)$ & $0.7256(2)$ & $0.2882(2)$ & 0.0803 & 1.0000 \\
\hline H231 & $0.8121(7)$ & $0.5652(2)$ & $0.22792(18)$ & 0.0793 & 1.0000 \\
\hline H232 & $0.6866(7)$ & $0.6267(2)$ & $0.19182(18)$ & 0.0783 & 1.0000 \\
\hline H233 & $0.5779(7)$ & $0.5475(2)$ & $0.21203(18)$ & 0.0792 & 1.0000 \\
\hline
\end{tabular}

Table S18 Anisotropic Displacement Parameters $\left(\AA^{2} \times 10^{3}\right)$ for $[5,5]$ allyl product. The Anisotropic displacement factor exponent takes the form: $-\pi^{2}\left[h^{2} a^{* 2} U_{11}+2 h k a * b * U_{12}+\ldots\right]$.

\begin{tabular}{|lllllll|}
\hline Label & \multicolumn{1}{c}{$\mathbf{U}_{11}$} & \multicolumn{1}{c}{$\mathbf{U}_{22}$} & $\mathbf{U}_{33}$ & \multicolumn{1}{c}{$\mathbf{U}_{23}$} & \multicolumn{1}{c|}{$\mathbf{U}_{13}$} & \multicolumn{1}{c|}{$\mathbf{U}_{12}$} \\
\hline O1 & $0.0243(10)$ & $0.0310(11)$ & $0.0287(10)$ & $-0.0055(8)$ & $0.0044(8)$ & $0.0015(8)$ \\
\hline O2 & $0.0192(10)$ & $0.0331(11)$ & $0.0365(11)$ & $0.0024(9)$ & $0.0024(9)$ & $-0.0007(9)$ \\
\hline O3 & 0.0596 & 0.0327 & 0.0333 & -0.0019 & -0.0256 & -0.0082 \\
\hline O4 & 0.0721 & 0.0368 & 0.0354 & 0.0008 & -0.0240 & -0.0122 \\
\hline
\end{tabular}




\begin{tabular}{|lllllll|}
\hline O5 & $0.0263(11)$ & $0.0318(12)$ & $0.0645(16)$ & $0.0133(11)$ & $0.0077(11)$ & $-0.0000(10)$ \\
\hline O6 & $0.0259(11)$ & $0.0397(12)$ & $0.0452(13)$ & $0.0192(11)$ & $-0.0006(9)$ & $-0.0012(10)$ \\
\hline C1 & $0.0178(13)$ & $0.0235(13)$ & $0.0225(13)$ & $-0.0003(11)$ & $-0.0003(10)$ & $-0.0004(11)$ \\
\hline C2 & $0.0211(13)$ & $0.0289(14)$ & $0.0192(12)$ & $0.0032(11)$ & $-0.0025(10)$ & $-0.0022(11)$ \\
\hline C3 & $0.0220(14)$ & $0.0317(15)$ & $0.0269(14)$ & $-0.0006(11)$ & $-0.0074(12)$ & $-0.0024(12)$ \\
\hline C4 & $0.0198(14)$ & $0.0198(13)$ & $0.0322(14)$ & $-0.0013(11)$ & $-0.0028(12)$ & $-0.0006(10)$ \\
\hline C5 & $0.0188(13)$ & $0.0208(13)$ & $0.0231(13)$ & $0.0007(10)$ & $-0.0016(11)$ & $-0.0016(10)$ \\
\hline C6 & $0.0273(14)$ & $0.0302(15)$ & $0.0225(13)$ & $0.0000(12)$ & $-0.0011(12)$ & $-0.0046(12)$ \\
\hline C7 & $0.0230(13)$ & $0.0269(14)$ & $0.0227(13)$ & $-0.0004(11)$ & $-0.0003(11)$ & $-0.0026(11)$ \\
\hline C8 & $0.0183(12)$ & $0.0251(14)$ & $0.0210(13)$ & $-0.0002(10)$ & $-0.0031(11)$ & $0.0002(11)$ \\
\hline C9 & $0.0242(14)$ & $0.0245(14)$ & $0.0384(16)$ & $0.0029(12)$ & $-0.0027(13)$ & $0.0009(11)$ \\
\hline C10 & $0.0313(16)$ & $0.0277(15)$ & $0.0489(19)$ & $0.0065(14)$ & $-0.0062(14)$ & $-0.0027(13)$ \\
\hline C11 & $0.052(2)$ & $0.047(2)$ & $0.061(2)$ & $0.0261(19)$ & $-0.008(2)$ & $-0.0044(18)$ \\
\hline C12 & 0.0370 & 0.0488 & 0.0440 & -0.0180 & -0.0173 & -0.0091 \\
\hline C13 & 0.0711 & 0.0372 & 0.0288 & -0.0072 & -0.0291 & -0.0020 \\
\hline C14 & 0.0910 & 0.0466 & 0.0631 & -0.0072 & -0.0258 & -0.0175 \\
\hline C15 & 0.0361 & 0.1102 & 0.0550 & -0.0230 & -0.0037 & -0.0174 \\
\hline C16 & 0.0411 & 0.1046 & 0.0352 & -0.0099 & -0.0066 & 0.0037 \\
\hline C17 & 0.0930 & 0.0630 & 0.0401 & -0.0136 & -0.0389 & 0.0313 \\
\hline C18 & $0.0249(15)$ & $0.0277(15)$ & $0.0507(19)$ & $0.0038(14)$ & $0.0074(14)$ & $-0.0020(13)$ \\
\hline C19 & $0.0257(15)$ & $0.0295(15)$ & $0.0435(18)$ & $0.0088(13)$ & $0.0074(14)$ & $-0.0006(13)$ \\
\hline C20 & $0.039(2)$ & $0.0396(19)$ & $0.073(3)$ & $-0.0118(19)$ & $0.0016(19)$ & $0.0069(16)$ \\
\hline C21 & $0.0370(19)$ & $0.054(2)$ & $0.054(2)$ & $0.0131(18)$ & $-0.0043(17)$ & $0.0032(16)$ \\
\hline C22 & $0.0311(19)$ & $0.048(2)$ & $0.081(3)$ & $0.007(2)$ & $-0.0044(19)$ & $-0.0050(17)$ \\
\hline C23 & $0.061(2)$ & $0.050(2)$ & $0.047(2)$ & $0.0139(17)$ & $0.0173(19)$ & $0.0191(19)$ \\
\hline B1 & $0.0301(16)$ & $0.0309(15)$ & $0.0217(14)$ & $-0.0055(12)$ & $-0.0040(13)$ & $-0.0000(13)$ \\
\hline B2 & $0.0235(16)$ & $0.0227(15)$ & $0.0227(14)$ & $-0.0010(11)$ & $-0.0024(12)$ & $-0.0015(12)$ \\
\hline
\end{tabular}

Table S19 Bond Lengths for [5,5] allyl product.

\begin{tabular}{|llllll|}
\hline Atom & Atom & Length/ $\AA$ & Atom & Atom & Length/ \\
\hline $\mathrm{O} 1$ & $\mathrm{C} 1$ & $1.428(3) \AA$ & $\mathrm{O} 2$ & $\mathrm{C} 4$ & $1.210(4) \AA$ \\
\hline $\mathrm{O} 3$ & $\mathrm{C} 12$ & $1.482(5) \AA$ & $\mathrm{O} 3$ & $\mathrm{~B} 1$ & $1.377(5) \AA$ \\
\hline $\mathrm{O} 4$ & $\mathrm{C} 13$ & $1.466(5) \AA$ & $\mathrm{O} 4$ & $\mathrm{~B} 1$ & $1.313(5) \AA$ \\
\hline $\mathrm{O} 5$ & $\mathrm{C} 18$ & $1.452(4) \AA$ & $\mathrm{O} 5$ & $\mathrm{~B} 2$ & $1.366(4) \AA$ \\
\hline $\mathrm{O} 6$ & $\mathrm{C} 19$ & $1.458(4) \AA$ & $\mathrm{O} 6$ & $\mathrm{~B} 2$ & $1.348(4) \AA$ \\
\hline $\mathrm{C} 1$ & $\mathrm{C} 2$ & $1.535(4) \AA$ & $\mathrm{C} 1$ & $\mathrm{C} 5$ & $1.580(4) \AA$ \\
\hline $\mathrm{C} 1$ & $\mathrm{C} 8$ & $1.545(4) \AA$ & $\mathrm{C} 2$ & $\mathrm{C} 3$ & $1.528(4) \AA$ \\
\hline $\mathrm{C} 2$ & $\mathrm{H} 21$ & $0.989 \AA$ & $\mathrm{C} 2$ & $\mathrm{H} 22$ & $0.958 \AA$ \\
\hline $\mathrm{C} 3$ & $\mathrm{C} 4$ & $1.515(4) \AA$ & $\mathrm{C} 3$ & $\mathrm{H} 31$ & $0.971 \AA$ \\
\hline
\end{tabular}




\begin{tabular}{|c|c|c|c|c|c|}
\hline C3 & H32 & $0.969 \AA$ & $\mathrm{C} 4$ & C5 & $1.527(4) \AA$ \\
\hline C5 & $\mathrm{C} 6$ & $1.551(4) \AA$ & C5 & C9 & $1.552(4) \AA$ \\
\hline C6 & $\mathrm{C7}$ & $1.548(4) \AA$ & C6 & H61 & $0.974 \AA$ \\
\hline C6 & H62 & $0.972 \AA$ & C7 & $\mathrm{C} 8$ & $1.546(4) \AA$ \\
\hline $\mathrm{C} 7$ & B1 & $1.582(4) \AA$ & C7 & H71 & $0.961 \AA$ \\
\hline $\mathrm{C} 8$ & B2 & $1.586(4) \AA$ & $\mathrm{C} 8$ & H81 & $0.954 \AA$ \\
\hline C9 & $\mathrm{C} 10$ & $1.499(4) \AA$ & C9 & H91 & $0.987 \AA$ \\
\hline C9 & $\mathrm{H} 92$ & $0.995 \AA$ & $\mathrm{C} 10$ & $\mathrm{C} 11$ & $1.298(5) \AA$ \\
\hline $\mathrm{C} 10$ & H101 & $0.933 \AA$ & C11 & H111 & $0.934 \AA$ \\
\hline $\mathrm{C} 11$ & $\mathrm{H} 112$ & $0.944 \AA$ & $\mathrm{C} 12$ & C13 & $1.540(8) \AA$ \\
\hline $\mathrm{C} 12$ & C14 & $1.497(7) \AA$ & $\mathrm{C} 12$ & C15 & $1.555(8) \AA$ \\
\hline $\mathrm{C} 13$ & C16 & $1.529(8) \AA$ & $\mathrm{C} 13$ & $\mathrm{C} 17$ & $1.544(7) \AA$ \\
\hline $\mathrm{C} 14$ & H141 & $0.956 \AA$ & C14 & $\mathrm{H} 142$ & $0.948 \AA$ \\
\hline $\mathrm{C} 14$ & $\mathrm{H} 143$ & $0.944 \AA$ & $\mathrm{C} 15$ & H151 & $0.947 \AA$ \\
\hline $\mathrm{C} 15$ & H152 & $0.959 \AA$ & $\mathrm{C} 15$ & H153 & $0.972 \AA$ \\
\hline $\mathrm{C} 16$ & H161 & $0.954 \AA$ & C16 & H162 & $0.936 \AA$ \\
\hline $\mathrm{C} 16$ & H163 & $0.940 \AA$ & C17 & H171 & $0.944 \AA$ \\
\hline $\mathrm{C} 17$ & $\mathrm{H} 172$ & $0.948 \AA$ & $\mathrm{C} 17$ & $\mathrm{H} 173$ & $0.953 \AA$ \\
\hline $\mathrm{C} 18$ & C19 & $1.563(4) \AA$ & $\mathrm{C} 18$ & C20 & $1.513(5) \AA$ \\
\hline $\mathrm{C} 18$ & $\mathrm{C} 21$ & $1.522(5) \AA$ & C19 & $\mathrm{C} 22$ & $1.501(5) \AA$ \\
\hline C19 & $\mathrm{C} 23$ & $1.543(5) \AA$ & $\mathrm{C} 20$ & H201 & $0.960 \AA$ \\
\hline $\mathrm{C} 20$ & H202 & $0.956 \AA$ & $\mathrm{C} 20$ & H203 & $0.954 \AA$ \\
\hline $\mathrm{C} 21$ & H211 & $0.977 \AA$ & $\mathrm{C} 21$ & $\mathrm{H} 212$ & $0.979 \AA$ \\
\hline $\mathrm{C} 21$ & $\mathrm{H} 213$ & $0.950 \AA$ & $\mathrm{C} 22$ & H221 & $0.984 \AA$ \\
\hline $\mathrm{C} 22$ & $\mathrm{H} 222$ & $0.996 \AA$ & $\mathrm{C} 22$ & $\mathrm{H} 223$ & $0.977 \AA$ \\
\hline $\mathrm{C} 23$ & H231 & $0.967 \AA$ & $\mathrm{C} 23$ & H232 & $0.975 \AA$ \\
\hline $\mathrm{C} 23$ & H233 & $0.987 \AA$ & & & \\
\hline
\end{tabular}

Table S20. Bond angles for [5,5] allyl product.

\begin{tabular}{|cccccccc|}
\hline Atom $\mathbf{1}$ & Atom $\mathbf{2}$ & Atom $\mathbf{3}$ & Angle & Atom 1 & Atom 2 & Atom 3 & Angle \\
\hline $\mathrm{C} 12$ & $\mathrm{O} 3$ & $\mathrm{~B} 1$ & $104.7(3)^{\circ}$ & $\mathrm{C} 13$ & $\mathrm{O} 4$ & $\mathrm{~B} 1$ & $107.9(3)^{\circ}$ \\
\hline $\mathrm{C} 18$ & $\mathrm{O} 5$ & $\mathrm{~B} 2$ & $107.7(2)^{\circ}$ & $\mathrm{C} 19$ & $\mathrm{O} 6$ & $\mathrm{~B} 2$ & $108.2(2)^{\circ}$ \\
\hline $\mathrm{O} 1$ & $\mathrm{C} 1$ & $\mathrm{C} 2$ & $106.7(2)^{\circ}$ & $\mathrm{O} 1$ & $\mathrm{C} 1$ & $\mathrm{C} 5$ & $114.2(2)^{\circ}$ \\
\hline $\mathrm{C} 2$ & $\mathrm{C} 1$ & $\mathrm{C} 5$ & $104.6(2)^{\circ}$ & $\mathrm{O} 1$ & $\mathrm{C} 1$ & $\mathrm{C} 8$ & $112.7(2)^{\circ}$ \\
\hline $\mathrm{C} 2$ & $\mathrm{C} 1$ & $\mathrm{C} 8$ & $113.8(2)^{\circ}$ & $\mathrm{C} 5$ & $\mathrm{C} 1$ & $\mathrm{C} 8$ & $104.8(2)^{\circ}$ \\
\hline $\mathrm{C} 1$ & $\mathrm{C} 2$ & $\mathrm{C} 3$ & $104.8(2)^{\circ}$ & $\mathrm{C} 1$ & $\mathrm{C} 2$ & $\mathrm{H} 21$ & $109.152^{\circ}$ \\
\hline $\mathrm{C} 3$ & $\mathrm{C} 2$ & $\mathrm{H} 21$ & $110.685^{\circ}$ & $\mathrm{C} 1$ & $\mathrm{C} 2$ & $\mathrm{H} 22$ & $110.629^{\circ}$ \\
\hline $\mathrm{C} 3$ & $\mathrm{C} 2$ & $\mathrm{H} 22$ & $114.065^{\circ}$ & $\mathrm{H} 21$ & $\mathrm{C} 2$ & $\mathrm{H} 22$ & $107.426^{\circ}$ \\
\hline $\mathrm{C} 2$ & $\mathrm{C} 3$ & $\mathrm{C} 4$ & $101.2(2)^{\circ}$ & $\mathrm{C} 2$ & $\mathrm{C} 3$ & $\mathrm{H} 31$ & $111.733^{\circ}$ \\
\hline
\end{tabular}




\begin{tabular}{|c|c|c|c|c|c|c|c|}
\hline C4 & C3 & H31 & $113.960^{\circ}$ & $\mathrm{C} 2$ & C3 & H32 & $111.330^{\circ}$ \\
\hline C4 & C3 & H32 & $110.418^{\circ}$ & H31 & C3 & H32 & $108.172^{\circ}$ \\
\hline $\mathrm{O} 2$ & $\mathrm{C} 4$ & C3 & $125.6(3)^{\circ}$ & $\mathrm{O} 2$ & C4 & C5 & $125.3(3)^{\circ}$ \\
\hline $\mathrm{C} 3$ & C4 & C5 & $109.1(2)^{\circ}$ & $\mathrm{C} 1$ & C5 & C4 & $103.8(2)^{\circ}$ \\
\hline $\mathrm{C} 1$ & C5 & C6 & $105.9(2)^{\circ}$ & C4 & C5 & C6 & $112.2(2)^{\circ}$ \\
\hline $\mathrm{C} 1$ & C5 & C9 & $112.6(2)^{\circ}$ & $\mathrm{C} 4$ & C5 & C9 & $108.9(2)^{\circ}$ \\
\hline $\mathrm{C} 6$ & C5 & C9 & $113.0(2)^{\circ}$ & C5 & C6 & C7 & $105.9(2)^{\circ}$ \\
\hline C5 & C6 & H61 & $108.177^{\circ}$ & C7 & C6 & H61 & $111.132^{\circ}$ \\
\hline $\mathrm{C} 5$ & C6 & H62 & $111.357^{\circ}$ & $\mathrm{C} 7$ & C6 & $\mathrm{H} 62$ & $110.905^{\circ}$ \\
\hline $\mathrm{H} 61$ & $\mathrm{C} 6$ & $\mathrm{H} 62$ & $109.267^{\circ}$ & C6 & C7 & C8 & $103.1(2)^{\circ}$ \\
\hline C6 & C7 & B1 & $115.0(2)^{\circ}$ & C8 & C7 & B1 & $110.2(2)^{\circ}$ \\
\hline C6 & $\mathrm{C} 7$ & H71 & $108.357^{\circ}$ & $\mathrm{C} 8$ & $\mathrm{C} 7$ & H71 & $107.709^{\circ}$ \\
\hline B1 & C7 & H71 & $111.918^{\circ}$ & $\mathrm{C} 1$ & C8 & C7 & $103.5(2)^{\circ}$ \\
\hline $\mathrm{C} 1$ & $\mathrm{C} 8$ & B2 & $114.5(2)^{\circ}$ & C7 & $\mathrm{C} 8$ & B2 & $115.6(2)^{\circ}$ \\
\hline $\mathrm{C} 1$ & C8 & H81 & $107.870^{\circ}$ & C7 & C8 & H81 & $107.912^{\circ}$ \\
\hline B2 & C8 & H81 & $107.119^{\circ}$ & C5 & C9 & $\mathrm{C} 10$ & $115.3(3)^{\circ}$ \\
\hline C5 & C9 & H91 & $107.099^{\circ}$ & $\mathrm{C} 10$ & C9 & H91 & $107.890^{\circ}$ \\
\hline $\mathrm{C} 5$ & C9 & $\mathrm{H} 92$ & $108.575^{\circ}$ & $\mathrm{C} 10$ & C9 & $\mathrm{H} 92$ & $107.322^{\circ}$ \\
\hline H91 & C9 & H92 & $110.623^{\circ}$ & C9 & C10 & $\mathrm{C} 11$ & $124.8(3)^{\circ}$ \\
\hline C9 & $\mathrm{C} 10$ & H101 & $117.309^{\circ}$ & $\mathrm{C} 11$ & $\mathrm{C} 10$ & H101 & $117.844^{\circ}$ \\
\hline $\mathrm{C} 10$ & $\mathrm{C} 11$ & H111 & $119.569^{\circ}$ & $\mathrm{C} 10$ & C11 & H112 & $117.324^{\circ}$ \\
\hline H111 & C11 & H112 & $123.092^{\circ}$ & O3 & $\mathrm{C} 12$ & $\mathrm{C} 13$ & $101.0(4)^{\circ}$ \\
\hline $\mathrm{O} 3$ & $\mathrm{C} 12$ & $\mathrm{C} 14$ & $106.2(5)^{\circ}$ & $\mathrm{C} 13$ & $\mathrm{C} 12$ & C14 & $117.4(5)^{\circ}$ \\
\hline $\mathrm{O} 3$ & $\mathrm{C} 12$ & $\mathrm{C} 15$ & $106.3(4)^{\circ}$ & $\mathrm{C} 13$ & $\mathrm{C} 12$ & $\mathrm{C} 15$ & $115.4(5)^{\circ}$ \\
\hline $\mathrm{C} 14$ & $\mathrm{C} 12$ & $\mathrm{C} 15$ & $109.1(6)^{\circ}$ & $\mathrm{O} 4$ & $\mathrm{C} 13$ & $\mathrm{C} 12$ & $101.2(3)^{\circ}$ \\
\hline $\mathrm{O} 4$ & $\mathrm{C} 13$ & $\mathrm{C} 16$ & $112.1(5)^{\circ}$ & $\mathrm{C} 12$ & $\mathrm{C} 13$ & C16 & $111.9(5)^{\circ}$ \\
\hline $\mathrm{O} 4$ & $\mathrm{C} 13$ & C17 & $106.5(4)^{\circ}$ & $\mathrm{C} 12$ & $\mathrm{C} 13$ & C17 & $113.1(5)^{\circ}$ \\
\hline $\mathrm{C} 16$ & $\mathrm{C} 13$ & $\mathrm{C} 17$ & $111.5(4)^{\circ}$ & $\mathrm{C} 12$ & $\mathrm{C} 14$ & H141 & $108.694^{\circ}$ \\
\hline $\mathrm{C} 12$ & $\mathrm{C} 14$ & H142 & $108.621^{\circ}$ & H141 & C14 & H142 & $110.418^{\circ}$ \\
\hline $\mathrm{C} 12$ & $\mathrm{C} 14$ & H143 & $108.918^{\circ}$ & H141 & C14 & H143 & $110.669^{\circ}$ \\
\hline H142 & $\mathrm{C} 14$ & H143 & $109.475^{\circ}$ & $\mathrm{C} 12$ & $\mathrm{C} 15$ & H151 & $108.086^{\circ}$ \\
\hline $\mathrm{C} 12$ & $\mathrm{C} 15$ & H152 & $108.950^{\circ}$ & H151 & C15 & H152 & $108.320^{\circ}$ \\
\hline $\mathrm{C} 12$ & $\mathrm{C} 15$ & H153 & $111.199^{\circ}$ & H151 & $\mathrm{C} 15$ & H153 & $108.983^{\circ}$ \\
\hline H152 & $\mathrm{C} 15$ & H153 & $111.208^{\circ}$ & $\mathrm{C} 13$ & $\mathrm{C} 16$ & H161 & $108.106^{\circ}$ \\
\hline $\mathrm{C} 13$ & $\mathrm{C} 16$ & H162 & $111.740^{\circ}$ & H161 & $\mathrm{C} 16$ & H162 & $110.338^{\circ}$ \\
\hline $\mathrm{C} 13$ & C16 & H163 & $109.830^{\circ}$ & H161 & C16 & H163 & $110.253^{\circ}$ \\
\hline H162 & $\mathrm{C} 16$ & H163 & $106.581^{\circ}$ & $\mathrm{C} 13$ & C17 & H171 & $106.903^{\circ}$ \\
\hline $\mathrm{C} 13$ & $\mathrm{C} 17$ & H172 & $110.706^{\circ}$ & H171 & C17 & H172 & $108.962^{\circ}$ \\
\hline $\mathrm{C} 13$ & $\mathrm{C} 17$ & H173 & $111.613^{\circ}$ & H171 & $\mathrm{C} 17$ & H173 & $110.355^{\circ}$ \\
\hline H172 & $\mathrm{C} 17$ & H173 & $108.279^{\circ}$ & O5 & C18 & $\mathrm{C} 19$ & $103.2(2)^{\circ}$ \\
\hline
\end{tabular}




\begin{tabular}{|cccccccc|}
\hline O5 & $\mathrm{C} 18$ & $\mathrm{C} 20$ & $107.0(3)^{\circ}$ & $\mathrm{C} 19$ & $\mathrm{C} 18$ & $\mathrm{C} 20$ & $114.3(3)^{\circ}$ \\
\hline $\mathrm{O} 5$ & $\mathrm{C} 18$ & $\mathrm{C} 21$ & $108.3(3)^{\circ}$ & $\mathrm{C} 19$ & $\mathrm{C} 18$ & $\mathrm{C} 21$ & $114.0(3)^{\circ}$ \\
\hline $\mathrm{C} 20$ & $\mathrm{C} 18$ & $\mathrm{C} 21$ & $109.5(3)^{\circ}$ & $\mathrm{O} 6$ & $\mathrm{C} 19$ & $\mathrm{C} 18$ & $102.9(2)^{\circ}$ \\
\hline $\mathrm{O} 6$ & $\mathrm{C} 19$ & $\mathrm{C} 22$ & $110.1(3)^{\circ}$ & $\mathrm{C} 18$ & $\mathrm{C} 19$ & $\mathrm{C} 22$ & $114.4(3)^{\circ}$ \\
\hline $\mathrm{O} 6$ & $\mathrm{C} 19$ & $\mathrm{C} 23$ & $105.4(3)^{\circ}$ & $\mathrm{C} 18$ & $\mathrm{C} 19$ & $\mathrm{C} 23$ & $112.3(3)^{\circ}$ \\
\hline $\mathrm{C} 22$ & $\mathrm{C} 19$ & $\mathrm{C} 23$ & $111.0(3)^{\circ}$ & $\mathrm{C} 18$ & $\mathrm{C} 20$ & $\mathrm{H} 201$ & $111.025^{\circ}$ \\
\hline $\mathrm{C} 18$ & $\mathrm{C} 20$ & $\mathrm{H} 202$ & $109.199^{\circ}$ & $\mathrm{H} 201$ & $\mathrm{C} 20$ & $\mathrm{H} 202$ & $110.050^{\circ}$ \\
\hline $\mathrm{C} 18$ & $\mathrm{C} 20$ & $\mathrm{H} 203$ & $109.433^{\circ}$ & $\mathrm{H} 201$ & $\mathrm{C} 20$ & $\mathrm{H} 203$ & $109.034^{\circ}$ \\
\hline $\mathrm{H} 202$ & $\mathrm{C} 20$ & $\mathrm{H} 203$ & $108.043^{\circ}$ & $\mathrm{C} 18$ & $\mathrm{C} 21$ & $\mathrm{H} 211$ & $108.401^{\circ}$ \\
\hline $\mathrm{C} 18$ & $\mathrm{C} 21$ & $\mathrm{H} 212$ & $110.645^{\circ}$ & $\mathrm{H} 211$ & $\mathrm{C} 21$ & $\mathrm{H} 212$ & $112.052^{\circ}$ \\
\hline $\mathrm{C} 18$ & $\mathrm{C} 21$ & $\mathrm{H} 213$ & $104.854^{\circ}$ & $\mathrm{H} 211$ & $\mathrm{C} 21$ & $\mathrm{H} 213$ & $110.979^{\circ}$ \\
\hline $\mathrm{H} 212$ & $\mathrm{C} 21$ & $\mathrm{H} 213$ & $109.667^{\circ}$ & $\mathrm{C} 19$ & $\mathrm{C} 22$ & $\mathrm{H} 221$ & $110.219^{\circ}$ \\
\hline $\mathrm{C} 19$ & $\mathrm{C} 22$ & $\mathrm{H} 222$ & $105.763^{\circ}$ & $\mathrm{H} 221$ & $\mathrm{C} 22$ & $\mathrm{H} 222$ & $106.513^{\circ}$ \\
\hline $\mathrm{C} 19$ & $\mathrm{C} 22$ & $\mathrm{H} 223$ & $112.116^{\circ}$ & $\mathrm{C} 22$ & $\mathrm{H} 223$ & $110.976^{\circ}$ \\
\hline $\mathrm{H} 222$ & $\mathrm{C} 22$ & $\mathrm{H} 223$ & $110.986^{\circ}$ & $\mathrm{C} 19$ & $\mathrm{C} 23$ & $\mathrm{H} 231$ & $107.087^{\circ}$ \\
\hline $\mathrm{C} 19$ & $\mathrm{C} 23$ & $\mathrm{H} 232$ & $111.363^{\circ}$ & $\mathrm{H} 231$ & $\mathrm{C} 23$ & $\mathrm{H} 232$ & $107.360^{\circ}$ \\
\hline $\mathrm{C} 19$ & $\mathrm{C} 23$ & $\mathrm{H} 233$ & $109.685^{\circ}$ & $\mathrm{H} 231$ & $\mathrm{C} 23$ & $\mathrm{H} 233$ & $110.176^{\circ}$ \\
\hline $\mathrm{H} 232$ & $\mathrm{C} 23$ & $\mathrm{H} 233$ & $111.067^{\circ}$ & $\mathrm{O} 3$ & $\mathrm{~B} 1$ & $\mathrm{O} 4$ & $113.9(3)^{\circ}$ \\
\hline $\mathrm{O} 3$ & $\mathrm{~B} 1$ & $\mathrm{C} 7$ & $120.9(3)^{\circ}$ & $\mathrm{B} 1$ & $\mathrm{C} 7$ & $125.0(3)^{\circ}$ \\
\hline $\mathrm{O} 5$ & $\mathrm{~B} 2$ & $\mathrm{O} 6$ & $113.9(3)^{\circ}$ & $\mathrm{O} 2$ & $\mathrm{C} 8$ & $121.9(3)^{\circ}$ \\
\hline $\mathrm{O} 6$ & $\mathrm{~B} 2$ & $\mathrm{C} 8$ & $124.2(3)^{\circ}$ & & & \\
\hline
\end{tabular}

Table S21 Hydrogen Atom Coordinates $\left(\AA \times 10^{4}\right)$ and Isotropic Displacement Parameters $\left(\AA^{2} \times 1^{3}\right)$ for $[5,5]$ allyl product.

\begin{tabular}{|cccccc|}
\hline Atom & $\mathbf{x} / \mathbf{a}$ & $\mathbf{y} / \mathbf{b}$ & $\mathbf{z} / \mathbf{c}$ & $\mathbf{U}(\mathbf{e q})$ & Occupancy \\
\hline H21 & -0.0013 & 0.4921 & 0.3003 & 0.0282 & 1 \\
\hline H22 & 0.1219 & 0.4581 & 0.2448 & 0.0283 & 1 \\
\hline H31 & -0.2356 & 0.4056 & 0.2578 & 0.0319 & 1 \\
\hline H32 & -0.067 & 0.3425 & 0.2489 & 0.0318 & 1 \\
\hline H61 & 0.1497 & 0.3773 & 0.4634 & 0.0315 & 1 \\
\hline H62 & -0.0739 & 0.4078 & 0.4492 & 0.0325 & 1 \\
\hline H71 & 0.0459 & 0.515 & 0.4013 & 0.0288 & 1 \\
\hline H81 & 0.4278 & 0.444 & 0.3887 & 0.0255 & 1 \\
\hline H91 & 0.2955 & 0.2805 & 0.3956 & 0.0344 & 1 \\
\hline H92 & 0.1532 & 0.2512 & 0.339 & 0.0344 & 1 \\
\hline H101 & -0.1031 & 0.2199 & 0.4147 & 0.0431 & 1 \\
\hline H111 & 0.0272 & 0.1616 & 0.4948 & 0.0645 & 1 \\
\hline H112 & 0.2532 & 0.1976 & 0.4774 & 0.0643 & 1 \\
\hline H141 & 0.5435 & 0.7018 & 0.5752 & 0.1 & 0.7329 \\
\hline
\end{tabular}




\begin{tabular}{|cccccc|}
\hline $\mathrm{H} 142$ & 0.3226 & 0.7078 & 0.5482 & 0.1002 & 0.7329 \\
\hline $\mathrm{H} 143$ & 0.5088 & 0.7233 & 0.5064 & 0.1001 & 0.7329 \\
\hline $\mathrm{H} 151$ & 0.7792 & 0.6018 & 0.5276 & 0.1011 & 0.7329 \\
\hline $\mathrm{H} 152$ & 0.7086 & 0.6243 & 0.4625 & 0.1008 & 0.7329 \\
\hline $\mathrm{H} 153$ & 0.6902 & 0.5378 & 0.4852 & 0.1003 & 0.7329 \\
\hline $\mathrm{H} 161$ & 0.1352 & 0.5487 & 0.6272 & 0.0909 & 0.7329 \\
\hline $\mathrm{H} 162$ & 0.2712 & 0.6193 & 0.6412 & 0.0902 & 0.7329 \\
\hline $\mathrm{H} 163$ & 0.1319 & 0.6216 & 0.5864 & 0.0907 & 0.7329 \\
\hline $\mathrm{H} 171$ & 0.4837 & 0.4744 & 0.6305 & 0.0981 & 0.7329 \\
\hline $\mathrm{H} 172$ & 0.6055 & 0.5495 & 0.6367 & 0.0979 & 0.7329 \\
\hline $\mathrm{H} 173$ & 0.6546 & 0.4944 & 0.5835 & 0.0977 & 0.7329 \\
\hline $\mathrm{H} 201$ & 0.4333 & 0.7681 & 0.3153 & 0.0758 & 1 \\
\hline $\mathrm{H} 202$ & 0.4241 & 0.7087 & 0.3692 & 0.0755 & 1 \\
\hline $\mathrm{H} 203$ & 0.2261 & 0.7318 & 0.3353 & 0.0756 & 1 \\
\hline $\mathrm{H} 211$ & 0.4169 & 0.7177 & 0.2058 & 0.0718 & 1 \\
\hline $\mathrm{H} 212$ & 0.1826 & 0.6994 & 0.225 & 0.0722 & 1 \\
\hline $\mathrm{H} 213$ & 0.3249 & 0.634 & 0.1993 & 0.0717 & 1 \\
\hline $\mathrm{H} 221$ & 0.9176 & 0.6525 & 0.3034 & 0.0797 & 1 \\
\hline $\mathrm{H} 222$ & 0.7589 & 0.681 & 0.3535 & 0.0787 & 1 \\
\hline $\mathrm{H} 223$ & 0.775 & 0.7256 & 0.2882 & 0.0803 & 1 \\
\hline $\mathrm{H} 231$ & 0.8121 & 0.5652 & 0.2279 & 0.0793 & 1 \\
\hline $\mathrm{H} 232$ & 0.6866 & 0.6267 & 0.1918 & 0.0783 & 1 \\
\hline $\mathrm{H} 233$ & 0.5779 & 0.5475 & 0.212 & 0.0792 & 1 \\
\hline & & & & & \\
\hline
\end{tabular}

\section{Experimental}

Single crystals of $\mathrm{C}_{23} \mathrm{H}_{38} \mathrm{~B}_{2} \mathrm{O}_{6}(-)-5 \mathbf{b}$ were grown from warm methanol/water upon cooling to room temperature and standing for about 1 week. A suitable crystal was selected and mounted on a Bruker APEX-II CCD' diffractometer. The crystal was kept at $150 \mathrm{~K}$ during data collection. The structure was solved using the program Crystals.

\section{- References}

${ }^{1}$ Green, J. C.; Joannou, M. V.; Murray, S. A.; Zanghi, J. M.; Meek, S. J. Enantio- and Diastereoselective Synthesis of Hydroxy Bis(boronates) via Cu-Catalyzed Tandem Borylation/1,2-Addition. ACS Catal. 2017, 7, 4441-4445.

${ }^{2}$ Katoa, K.; Matsubaa, C.; Kusakabea, T.; Takayamaa, H.; Yamamuraa, S.; Mochidab, T.; Akitaa, H.; Peganovac, T. A.; Vologdinc, N. V.; Gusev, O. V. 2,2'-Isopropylidenebis[(4S,5R)-4,5-di(2-naphthyl)-2oxazoline] Ligand for Asymmetric Cyclization-Carbonylation of Meso-2-alkyl-2-propargylcyclohexane1,3-diols. Tetrahedron. 2006, 62, 9988-9999.

${ }^{3}$ Harris, E. B. J.; Banwell, M. G.; Willis, A. C. Protecting Group Free Syntheses of $( \pm)$-Columbianetin and (士)-Angelmarin. Tetrahedron Lett. 2011, 52, 6887-6889.

${ }^{4}$ Zhu, C.; Wang, D.; Zhao, Y.; Sun, W.-Y.; Shi, Z. Enantioselective Palladium-Catalyzed Intramolecular $\alpha-$ Arylative Desymmetrization of 1,3-Diketones. J. Am. Chem. Soc. 2017, 139, 16486-16489. 
${ }^{5}$ Clarke, C.; Incerti-Pradillos, C. A.; Lam, H. W. Enantioselective Nickel-Catalyzed anti-Carbometallative Cyclizations of Alkynyl Electrophiles Enabled by Reversible Alkenylnickel E/Z Isomerization. J. Am. Chem. Soc. 2016, 138, 8068-8071.

${ }^{6}$ Zhu, S.; Zhang, Q.; Chen, K.; Jiang, H. Synergistic Catalysis: Metal/Proton-Catalyzed Cyclization of Alkynones Toward Bicyclo[3.n.1]alkanones. Angew. Chem. Int. Ed. 2015, 54, 9414-9418.

7 Schneider, L. M.; Schmiedel, V. M.; Pecchioli, T.; Lentz, D.; Merten, C.; Christmann, M. Asymmetric Synthesis of Carbocyclic Propellanes. Org. Lett. 2017, 19, 2310-2313.

${ }^{8}$ Ramachary, D. B.; Kishor, M. Direct Amino Acid-Catalyzed Cascade Biomimetic Reductive Alkylations: Application to the Asymmetric Synthesis of Hajos-Parrish Ketone Analogues. Org. Biomol. Chem., 2008, 6 , 4176-4187.

9 Schick, H.; Roatsch, B.; Schramm, S.; Gilsing, H.-D.; Ramm, M.; Gründemann, E. Conversion of 2-Alkyl2-(2-oxopropyl)cyclopentane-1,3-diones into 2,3,5- and 2,3,4-Trisubstituted Cyclopent-2-enones by Intramolecular Aldolizations to 2,3-Diacylcyclopropanolates Followed by Remarkable Skeletal Rearrangements. J. Org. Chem. 1996, 61, 5788-5792.

${ }^{10}$ Kallepu, S.; Gollapelli, K. K.; Nanubolu, J. B.; Chegondi, R. Synthesis of Highly Strained Bicyclic[3.n.1]alkenes by a Metal-Catalyzed Conia-ene Reaction. Chem. Commun. 2015, 51, 16840-16843.

${ }^{11}$ Lenhart, J. A.; Ling, X.; Gandhi, R.; Guo, T. L.; Gerk, P. M.; Brunzell, D. H.; Zhang, S. “Clicked” Bivalent Ligands Containing Curcumin and Cholesterol As Multifunctional A $\beta$ Oligomerization Inhibitors: Design, Synthesis, and Biological Characterization. J. Med. Chem. 2010, 53, 6198-6209.

${ }_{12}$ Bacchi, A.; Costa, M.; Cà, N. D.; Gabriele, B.; Salerno, G.; Cassoni, S. Heterocyclic Derivative Syntheses by Palladium-Catalyzed Oxidative Cyclization-Alkoxycarbonylation of Substituted $\gamma$-Oxoalkynes. J. Org. Chem. 2005, 70, 4971-4979.

${ }^{13}$ Deschamp, J.; Riant, O. Efficient Construction of Polycyclic Derivatives via a Highly Selective CuICatalyzed Domino Reductive-Aldol Cyclization. Org. Lett. 2009, 11, 1217-1220. 